\title{
THE INCOMPARABLE CHIEF JUSTICESHIP OF WILLIAM HOWARD TAFT
}

\author{
Robert Post* \\ 2019 VISIONARY ARTICLE IN CONSTITUTIONAL LAW
}

2020 Mich. ST. L. REV. 1

TABLE OF CONTENTS

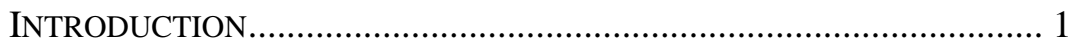

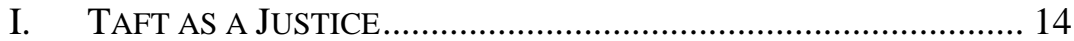

II. THE CONFERENCE OF SENIOR CIRCUIT COURT JUDGES.......... 31

III. MANAGING THE SUPREME COURT .............................................. 63

IV. REFORMING THE JURISDICTION OF THE SUPREME COURT ...... 68

V. The CHANGING Role OF CHIEF JUSTICE ............................... 88

VI. ROLE CONFLICTS IN PROTECTING THE FEDERAL JUDICIARY .. 95

VII. A DEEP COMMITMENT TO JUDICIAL REFORM ...................... 122

VIII. LOBBYING FOR JUDICIAL APPOINTMENTS........................... 124

IX. A NEW SUPREME COURT BUILDING .................................... 139

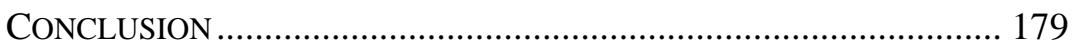

\section{INTRODUCTION}

During his brief tenure on the Supreme Court, William Howard Taft inhabited three distinct roles. He was a Justice who, like his peers, wrote opinions and voted on the outcome of cases. He was a Chief Justice, who administered not only the Court itself, but also, to an ever-expanding extent, the entire federal judicial system. And he was a judicial reformer, who worked through political means to enact legislation to improve the operation of federal justice.

Taft exercised each of these three roles with immense capacity and prodigious energy. As a Justice, he authored far more opinions than any of his peers, as indicated in Figure 1. He frequently accepted responsibility for drafting the most difficult and important cases facing the Court. As a Chief Justice, Taft was responsible not merely for steering the Court's deliberations and managing all of its many bureaucratic functions, but also for such additional tasks as briefing

* $\quad$ Sterling Professor of Law, Yale Law School. 
certiorari petitions for the Court's conference, ${ }^{1}$ considering in forma pauperis petitions, preparing Court orders, and so forth. ${ }^{2}$

As a judicial reformer, Taft fundamentally altered the structure of federal courts, as well as of the Supreme Court, through such landmark legislation as the Act of September 14, $1922^{3}$ and the Judiciary Act of February 13, 1925. ${ }^{4}$ As Taft sought aggressively to reform both the Court and the federal judiciary in ways he believed would make them more effective and efficient, he correspondingly transformed the role of Chief Justice into something like a chief executive for the federal judiciary. This in turn expanded his administrative responsibilities. The upshot, as Louis D. Brandeis observed to Felix Frankfurter, was that Taft "does about two men's work - with his added administrative tasks, extra work on certiorari etc. etc." ${ }^{5}$

It is no exaggeration to say that Taft literally worked himself to death during his years on the Court. ${ }^{6}$ He pushed relentlessly on a

1. Jurisdiction of the Circuit Courts of Appeals and of the Supreme Court of the United States: Hearing on H.R. 8206 Before the H. Comm. On the Judiciary, 68th Cong. 27 (1924) (statement of Chief Justice William Howard Taft, Supreme Court of the United States) ("I write out every case that comes up for certiorari and I read it to the court. I think the members of the court are a little impatient sometimes because I give too much detail. Perhaps that is because I am a new member, or was a new member."); C. Dickerman Williams, The 1924 Term: Recollections of Chief Justice Taft's Law Clerk, 1989 YeArboOK OF THE SuPREME COURT HistoriCAL Society 40, 43 (1989); Address of Justice Sutherland, 20 Proc. Twentieth Ann. SESSION ST. BAR AsS'N OF UTAH 60 (1924).

2. Gregory Hankin \& Charlotte A. Hankin, Progress of the LaW in THE U.S. SUPREME COURT 1929-1930 5-6 (1930).

3. Pub. L. No. 67-298, 42 Stat. 837 (1922).

4. Pub. L. 68-415, 43 Stat. 936 (1925).

5. Melvin I. Urofsky, The Brandeis-Frankfurter Conversations, 1985 SUP. CT. REv. 299, 321 (1985) [hereinafter Brandeis-Frankfurter Conversations]. Taft himself estimated that "I have to do about a third more work than the members of the Court. And it is very continuous and exacting." Letter from William Howard Taft, Chief Justice, U.S. Supreme Court [hereinafter WHT], to Clarence H. Kelsey (May 2, 1923) (Taft papers).

6. Early in his career as Chief Justice, the press published a grueling account of Taft's "typical" workday:

Mr. Taft is up every morning at 5:30 o'clock. By 6:15 he is at work in his study in his house. (None of the justices has an office. All of them do all of their work at home.) He works until 8:30, when he has breakfast. At 9:00 he is at his desk again and stays there until 10:15, when he starts to walk from his house to the Supreme Court Chamber in the Capitol. That is a little journey of three and seven-tenths miles. . . As Chief Justice he then has a certain amount of routine administrative and executive business to dispose. He barely gets through before noon, when the Court opens its session to 
staggering array of projects until the very end of his tenure. His last great accomplishment, securing funding for the new Supreme Court building that he conceived and designed, was achieved on December $20,1929,7$ barely two weeks before his final collapse.

Figure 1. Number of Opinions Authored by Each Justice

\begin{tabular}{|c|c|c|c|c|c|c|c|c|c|}
\hline $\begin{array}{l}\text { Court } \\
\text { Terms } \\
\end{array}$ & Taft & Holmes & $\begin{array}{l}\text { Van } \\
\text { Devanter }\end{array}$ & McReynolds & Brandeis & Sutherland & Butler & Sanford & Stone \\
\hline $\begin{array}{l}1921- \\
1928\end{array}$ & 249 & 205 & 94 & 172 & 193 & & & & \\
\hline $\begin{array}{l}1922- \\
1928\end{array}$ & 222 & 176 & 84 & 152 & 170 & 143 & & & \\
\hline $\begin{array}{l}1923- \\
1928\end{array}$ & 176 & 146 & 70 & 129 & 143 & 113 & 137 & 113 & \\
\hline $\begin{array}{l}1925- \\
1928\end{array}$ & 110 & 86 & 39 & 78 & 87 & 60 & 88 & 69 & 95 \\
\hline
\end{tabular}

Taft entered the Court at the age of 63, an apparently healthy man - obese but living a more or less normal, vigorous life. In 1922, he could joke to a friend who had been committed to a sanitarium because of a weakened heart and rheumatism, "I, too, suffer from a rheumatic knee, though I play golf and do considerable walking .... I suppose my heart is pretty weak, too, from having used it too much to pump blood through a great deal of adipose tissue, but still I wear on with the hope that I will last for some little time."

In fact, Taft's blood pressure was far too high, and his heart displayed worrisome indications. A month after writing his friend, he told his son:

I have had to let up in my regular golf, because I found that with some increase in weight, about ten pounds or more, the walk all the way around the links, especially in warm weather, produced a palpitation of the heart that I did not like, and I am going to confine myself to nine holes from now on. I have got to reduce myself, too. ... My heart has been all right, so the physicians tell me, but sometimes it is a little tired, and they have discovered

hear arguments and pleadings. It sits until 4:30 o'clock, with a half hour intermission for lunch.

Mr. Taft drives home every afternoon and is at his desk again at 5:30 o'clock. He works until 6:45, has dinner at 7, goes upstairs to his desk at 8 , and gets in two solid hours of labor before going to bed, at 10 o'clock.

Edward G. Lowry, Editorial, PUB. LEDGER (Phila.), Oct. 28, 1922, reprinted in N.Y. TIMES, Oct. 28, 1922, at 11.

7. Pub. L. No. 71-26, 46 Stat. 51 (1929) (providing for the construction of a building for the Supreme Court of the United States).

8. Letter from WHT to George Benjamin Edwards (Aug. 23, 1922) (Taft papers). 
a murmur at times. My pulse is very low, but it has always been. It is about 50. My blood pressure sometimes goes up to 180 , though it is usually down to 170 . All this indicates that I have to be careful if I wish to continue to be active. $^{9}$

Taft suffered his first serious symptoms of cardiac illness in February 1924 when "a sharp digestive" attack brought on disabling heart palpitations..$^{10} \mathrm{He}$ returned to the Court ten days later feeling "much like myself" and resolving "to try to do less work and possibly to do it better." ${ }^{11}$ But in April the palpitations returned. ${ }^{12}$ For a month Taft stayed in bed except when in Court, "and then the Doctor thought I ought to take a complete rest and I went to bed for eight days." ${ }^{13} \mathrm{He}$ was diagnosed with an enlarged heart and cardiac arrhythmia, and he

9. Letter from WHT to Charles P. Taft II (Sept. 4, 1922) (Taft papers). Taft's blood pressure continued high throughout his tenure as Chief Justice. See, e.g., Letter from WHT to Horace D. Taft (June 8, 1927) ("I had the Doctor go over me yesterday and he found that my heart beat was down to 52 . He found my blood pressure was 180, but 115 in the diastole, which I think is too high. . . [T] seemed to be quite well satisfied.").

10. See Letter from WHT to Horace D. Taft (Feb. 6, 1924) (Taft papers):

I had an attack of palpitation of the heart this morning, brought on I suppose by a sharp digestive attack, and with diarrhea. I sent for the Doctor and he found what I had already found, that my pulse was running fast and irregularly. He said that what I needed was rest, and that I could not go to Woodrow Wilson's funeral this afternoon, where I had intended to go as a pall bearer. I would have given anything to go, not alone to pay a tribute to a deceased President, but also to avoid the circulation against alarming reports as to my illness. I explained that to the Doctor and he Doctor seemed to realize the awkwardness of it, but it did not abate his insistence that I should be quiet and run no risk. There is only one living ex-President, and I don't care to reduce that number, so I obey orders. . . . I thought I was in fine condition, but I have been gaining some flesh.

11. Letter from WHT to Horace D. Taft (Feb. 16, 1924) (Taft papers); Letter from WHT to James E. Gregg (Feb. 15, 1924) (Taft papers) ("The truth is I have had a pretty close call to a breakdown. I hope, however, to go back to Court on Monday, with a warning that I can not do all the work there is to do. I was treating myself as I might have treated myself thirty years ago. There is no fool like an old fool. There is some hope, however, if he mends his ways.").

12. Letter from WHT to Horace D. Taft (Apr. 25, 1924) (Taft papers) ("I have had a return of that palpitation of the heart. . . I had thought that I was getting along very well indeed . . . but I ate something or did something to affect a nerve, and so I am under orders again.”).

13. Memorandum from WHT to his Family (June 8, 1924) (Taft papers). "The truth is," Taft wrote the President of Yale, that "I have overdone things in the matter of my work. I have proceeded on the theory that I was younger than I am, and I can not be useful unless I cut out all my activities and devote myself solely to the requirements of the Bench.” Letter from WHT to James R. Angell (May 31, 1924) (Taft papers). 
was treated with digitalis and a compound of quinine. ${ }^{14} \mathrm{He}$ was warned "that I had passed the turn in the road and that I would have to careful," but he was given "hope that I might live a long time . . . . It depends upon whether I am sensible and don't overdo and don't overeat and don't over exercise. I don't expect to play golf or to take any other exercise than walking, and not very much uphill."15

A slight recurrence on the opening day of the 1924 Term frightened Taft. ${ }^{16} \mathrm{He}$ resolved to amend his ways. "I am able . . . to keep up with my work on the Bench," he wrote a friend three months later, "but I do not strain myself to do as much work as I did for the first three years. I have had a warning and I am trying to respect it." 17

14. See Memorandum from WHT, supra note 13; see also Letter from WHT to Clarence H. Kelsey (June 7, 1924) (Taft papers). Taft would today likely be diagnosed with paroxysmal atrial fibrillation, for which obesity is a known risk factor. Atrial fibrillation is associated with an increased risk of strokes. Quinine is now known to increase the risk of arrhythmia.

15. Letter from WHT to Clarence H. Kelsey (June 7, 1924) (Taft papers). In September Taft wrote Brandeis that "there has been no recurrence of the heart fibrillation, though at times there has been some thumping that gave me concern, but I hope that it is not a serious symptom. On the whole, I have had a satisfactory summer, although I have had to give up golf and confine such exercise as I have taken to slow walks to the golf course and back again." Letter from WHT to Louis Dembitz Brandeis, Justice, U.S. Supreme Court [hereinafter LDB] (Sept. 9, 1924) (Taft papers).

16. See, e.g., Letter from WHT to Horace D. Taft (Oct. 10, 1924) (Taft papers):

The first day of the Court was a pretty exciting one, and I ate some roast pork, something I rarely do, although I love the meat. I had a heavy cold, waked up in a sweat about one o-clock, and found my heart going as it did last January. ... Visions of a recurrence of the trouble and of my having to stay home from Court came over me, and I was a good deal alarmed. Indeed it seemed to me as if I might have to give up the office and spend my time trying to live.

Two days later Taft wrote his son,

We had had an unusually heavy docket, and I am afraid I worked too hard on it..... If I find that this is going to recur so as to interfere with my work, I shall have to get out of the Court and devote my attention to living. . . . It is a serious issue that may present itself. If Coolidge is to be reelected, then there will be no trouble from the standpoint of the friends of the Constitution, but if not, I suppose I shall have to hang on as long as I can, because if there is any chance of Bryan's getting in, it will be difficult to get anybody confirmed in my place. . . I must do my work or else cry quits, and I presume this winter will disclose pretty certainly the situation.

Letter from WHT to Charles P. Taft II (Oct. 12, 1924) (Taft papers); see also Letter from WHT to Mrs. Frederick J. Manning (Oct. 12, 1924) (Taft papers).

17. Letter from WHT to Henry E. Coe (Jan. 7, 1925). In February, with his typical bluntness, McReynolds wrote Taft's former Secretary of War that "[ $\mathrm{t}] \mathrm{he}$ Chief 
But then in June 1926 Taft forgot himself. Taft, along with Willis Van Devanter, George Sutherland, Pierce Butler, and Edward T. Sanford, all agreed to judge a high school National Oratorical Contest on the subject of "The Constitution," a contest designed to "inculcate love of country and good citizenship in the youth of the land." 18 The

has at last found out that he must be careful. I fear it is too late. His heart is bad." Letter from James C. McReynolds [hereinafter JCM] to Jacob McGavock Dickinson (Feb. 5, 1925) (Jacob McGavock Dickinson Papers Tenn. State Library \& Archives). After a restful summer in 1925, Taft wrote a friend that "I have to be very careful, in view of the warnings that I have had, but on the whole I seem to have gotten along so that I am going back to Washington, trusting that with care I may be able to pull my weight into the boat, as I did last year." Letter from WHT to S.A. Perkins (Sept. 19, 1925) (Taft papers). As the Term began, Taft wrote a Kansas newspaper editor that "I haven't had a heart attack for more than a year, but it was a severe warning and one that requires me to observe the greatest care, and of course keeps the suggestion before me that when the pump is out of order, or can easily get out of order, no one knows what may happen. However, I have been able to pull my weight in the boat, that is to do my share on the Bench, but I am trying to avoid too intense application in order to pursue the quiet life that is needed." Letter from WHT to Charles F. Scott (Nov. 21, 1925) (Taft papers).

Taft nevertheless took prudent precautions to guard against the possibility of a medical retirement. He had written Coolidge the previous June that "[w]hen I visited the White House some days ago, I spoke to you of an amendment to the law which would facilitate my retirement if it seemed wise, after I became seventy. I was born on the 15th of September, 1857, and, if I live, I shall reach the age of seventy on the 15th of September, 1927." Letter from WHT to Calvin Coolidge, President, U.S. (June 4, 1925) (Taft papers).

Taft's proposed amendment would allow judges to accrue non-continuous retirement credit, so that Taft could count his years as a Circuit Judge toward his retirement. Coolidge asked Taft to "remind me of this at the time of the opening of Congress." Letter from Calvin Coolidge to WHT (June 4, 1925) (Taft papers). True to his word, Coolidge recommended in his annual message in December that "the term of years of service of judges of any court of the United States requisite for retirement with pay shall be computed to include not only continuous but aggregate service." Message of the President of the United States, 67 Cong. REC. 463 (Dec. 8, 1925). Coolidge's recommendation was not ultimately enacted into law until 1929. See Pub. L. 70-870, 45 Stat. 1422 (1929); H.R. REP. No. 70-2678, at 1, 2 (1929); S. REP. No. 70-1511, at 1 (1929). The significance of Coolidge's proposal, however, was not lost on the sharp-eyed McReynolds, who wrote J.M. Dickinson that "[t]he Ch. Justice has the appearance of being in pretty good health," but that "[t]he Presidents [sic] message suggesting the judges be allowed to add all years of service in order to retire was probably intended to help the $\mathrm{Ch}$. $\mathrm{J}$ in case of an emergency." Letter from JCM to Jacob McGavock Dickinson, former Sec'y of War (Dec. 13, 1925) (Jacob McGavock Dickinson Papers, Tenn. State Library \& Archives).

In January 1926, "after taking a drive with Van Devanter and Butler," Taft "walked faster than I should" and had a brief episode of heart palpitations. Letter from WHT to Robert A. Taft (Jan. 31, 1926) (Taft papers).

18. Los Angeles Boy First in Contest of School Orators, N.Y. Times, June 5, 1926, at 1. 
winning orator, a student from Hollywood High School in Los Angeles, began his speech with a full throated appeal: "From the beginning of recorded time the force that has propelled civilization forward has been man's desire for freedom. When that desire fails, the wheels of progress cease their turning." 19 To judge the contest, Taft had to climb "up three or four flights of stairs" 20 to "the top of the theater," ${ }^{21}$ and "that set my heart going." 22

The palpitations proved "obstinate" 23 and became a turning point in Taft's health. He was forced to miss the closing of Court, and his palpitations persisted throughout his summer vacation at Murray Bay in Canada. ${ }^{24}$ Taft fretted that his heart condition might "threaten my

19. Id. at 6. The New York Times reproduced the entire text of the winning oration, which contained passages like:

Only an American, one who knows our history, can feel the sacred symbolism of that Constitution; only one whose soul is steeped in the spirit of the far-off days when the old meeting-house in Philadelphia felt the throb of the great hearts of the constitutional fathers can understand.

What solemn obligation is ours, to teach those who come among us from foreign shores, and who often, all too often, come to scoff because they do not understand. And here is our duty, here is our obligation, too, for those who do not know must be enlightened; and those who do not care must be taught to love our institutions, and the Constitution by which they live.

And for those who come with hatred in their hearts, ladies and gentlemen, no words of mine could fully express the indignation that should rouse every true American heart to stand on guard as they did on Concord Bridge, who gave to us our flag, our country, our Constitution.

Id.

20. Letter from WHT to Clarence H. Kelsey (June 9, 1926) (Taft papers). At this point Taft decided to have an elevator installed in his home. See id.

21. Letter from WHT to Horace D. Taft (June 5, 1925) (Taft papers).

22. Letter from WHT to Clarence H. Kelsey (June 9, 1926) (Taft papers).

23. Letter from WHT to Franklin W. Cram (June 15, 1926) (Taft papers).

24. See, e.g., Letter from Willis Van Devanter, Justice, U.S. Supreme Court [hereinafter WVD], to Pierce Butler, Justice, U.S. Supreme Court [hereinafter PB] (June 21, 1926) (Van Devanter papers) ("I saw the Chief Justice Saturday. He was not as much encouraged about his own situation as he would like to be. He had been counting on going away tomorrow, but the doctor was advising a postponement to Friday. I endeavored to give some reasons for following the doctor's advice and at the same time tried to develop some grounds for encouragement."). On July 9, 1926, Taft wrote Van Devanter after arriving at his summer home in Canada:

I think I have been better here than I was in New Haven. At least the doctor says so. But still the pacemaker of the heart has not got onto its trolley yet. The doctor here, who is a very good doctor, is testing me before he tries another strong dose of digitalis. I haven't done any work, and I have concluded to ask Pierce Butler to take over that long, heavy case of the Chemical Foundation. [United States v. Chemical Foundation, Inc., 272 U.S. 1 (1926).] I am afraid to undertake it myself, because I must reduce the 
usefulness on the Bench. I am doing the best I can to abate the trouble, and the three months' vacation that we have helps along. . . . My general health has been very good, but the work on the Court is persistent and heavy, and it falls especially on the Chief Justice. I love it, and I shall struggle to stay on as long as I can . . . ." ${ }_{25}$ "The newspapers," he complained to his friend Elihu Root, "are determined to bury me before I am willing to be buried." But "I would like to serve out a full ten" years. "If I have strength to fill the decade, I foresee some questions coming before our Court for decision that I should like to take part in deciding." 26

work this summer as much as I can in order to give full opportunity for a return to normal. Pierce is young and strong, able and willing, and I thought I would trespass on him. He is the only one to whom I can properly give it. He was appointed by Harding and not by Wilson, and I rather think we ought to have somebody other than an appointee of Wilson to consider and decide the case.

Letter from WHT to WVD (July 9, 1926) (Van Devanter papers).

25. Letter from WHT to Alfred L. Ripley (Aug. 5, 1926) (Taft papers):

I have had, as you know, trouble with my heart for now more than two years. It is recurrent. It is what is called "heart fibrillation" . . I haven't succeeded as yet this summer in getting back to normal regularity. . . . I don't like it, and I think it may interfere more or less with my work. I have not been five years on the Supreme Bench. If I could be spared for five years more, I could under the law retire on my salary and devote myself to quiet and to an arrangement of my papers for use by my children in such memoirs as they might think it wise to give out if they deem it so....

I love the work in the Supreme Court, but during the term it is hard and pressing, and I don't know whether I shall be able to continue it through the remaining five years, much as I would like to, but whatever comes, I shall never cease to be grateful for what I have had and the opportunities for usefulness which have been presented to me, as well as for the happiness accompanying such a family and such friends.

Letter from WHT to Mrs. Charles D. Norton (Aug. 10, 1926) (Taft papers).

26. Letter from WHT to Elihu Root (Aug. 19, 1926) (Taft papers). "The Doctor tells me that I am getting along well and that I am growing better, and that if I keep myself within the bounds of moderation, and don't attempt too much exertion, my general condition is such as to make it possible for me to live some time." Id. Root replied that

[t]he men who have really learned the lesson of taking care of themselves ordinarily have to be taken out and shot by their sorrowing friends in order to get rid of them. I take the same cheerful view of your judicial duties. . . . The best Judge as well as the longest liver is rather unemotional, unimaginative, indifferent, and stodgy. Try being a little stodgy, my dear Porthos, and people will be sending telegrams of congratulation to you on your one hundred and fourth birthday.

Letter from Elihu Root to WHT (Sept. 8, 1926) (Taft papers). Taft replied, "Your recommendation seems to be that I make myself 'unemotional, unimaginative, indifferent and stodgy'. I don't think that your prescription imposes on me the taking 
The start of the 1926 Term filled Taft "with a great deal of anxiety." ${ }^{27} \mathrm{He}$ feared "the change from the lazy life I have been living here to the routine of Court work." ${ }^{28}$ He dreaded "the effect upon my heart and me." ${ }^{29}$ When he arrived in Washington, Taft reported to his brother that "I am as careful as I can be. I am trying to see if I cannot hold myself in such [a] way as to continue work. My fibrillation continues but it is not excessive and I am hopeful that by care, I may avoid it being so." ${ }^{30} \mathrm{He}$ remained relatively stable for a year, ${ }^{31}$ but nevertheless for the remainder of his life he judged himself to be a man with a "defective" heart, "so that I have been obliged to lead a life of seclusion and avoid entirely the work of agitation [and] of addresses." $32 \mathrm{He}$ described himself as "really in an invalid state" so that he had to be "very careful to restrain myself as much as I can." 33 As he wrote to the President of the American Philosophical Society, "I am doing the best I can to meet my duties as a partial invalid and under direct medical restraint." 34

A darker and more frightening disability also began to take hold. In the fall of 1927, having turned seventy, he wrote his daughter that he feared that "my mental faculties are dulling a bit and that it takes

of a very long step. Indeed I think I have already arrived." Letter from WHT to Elihu Root (Sept. 17, 1926) (Taft papers).

27. Letter from WHT to Charles P. Taft II (Sept. 23, 1926) (Taft papers).

28. Id. Taft wrote Sanford in August that "when I come back I shall not be as well as I was last winter, because my heart beat will probably not be normal, and I must therefore husband my strength and not attempt too much. But I am sure that you brethren will make allowance for my situation and understand me if I favor myself a bit in the distribution of cases." Letter from WHT to Edward T. Sanford, Justice, U.S. Supreme Court (Aug. 21, 1926) (Taft papers).

29. Letter from WHT to Horace D. Taft (Sept. 23, 1926) (Taft papers).

30. Letter from WHT to Henry W. Taft (Sept. 20, 1926); see Letter from WHT to Harry C. Coe (Oct. 2, 1926) (Taft papers). Taft reported to his daughter that "I lost some sleep this week, due to nervousness I suppose, and I did think at one time that I was in for a delay, due to my condition, but I got over the symptoms that were disturbing." Letter from WHT to Mrs. Frederick J. Manning (Oct. 3, 1926) (Taft papers).

31. The danger posed by his heart condition never left Taft's mind. In a daily memorandum containing his "to-do list" for February 6, 1927, Taft noted that it was " 3 yrs ago as I recollect it I had my first attack of fibrillation. It was the day of the funeral of Woodrow Wilson." Memorandum from WHT (Feb. 6, 1927) (Taft papers).

32. Letter from WHT to Gordon Edwards (Jan. 28, 1928) (Taft papers).

33. Letter from WHT to R. Walton Moore, Va. Congressman (Apr. 19, 1928) (Taft papers).

34. Letter from WHT to Francis X. Dercum (Jan. 7, 1929) (Taft papers). 
more work for me to get hold of questions and to dispose of them." 35 Taft began to worry about "the elasticity of the arteries, and especially the arteries in the brain." 36 A year later, Taft complained that "I now find that it is much harder for me to concentrate my mind and to bring about the hard application that is necessary to make my work as useful as it used to be when my powers were better." 37 "My mind moves slowly, and I have great difficulty in arranging my opinions as I would like to." 38 "The truth is," Taft wrote a friend, "that my mind does not work as well as it did, and I scatter." ${ }^{39}$ Two months before his fatal

35. Letter from WHT to Mrs. Frederick J. Manning (Oct. 23, 1927) (Taft papers). "However, I have to stay on the Bench until 1931," Taft continued, "in order to earn my pension, and that I must struggle to do, unless I am so weakened that I can not do the work." Id. In this letter Taft gives a sketch of his day that is worth comparing to the description published in 1922. Compare id., with Lowry, supra note 6 , at 11. Upon the advice of his doctor, Taft had hired a masseur to improve his circulation. The masseur, Taft wrote his daughter,

comes about six o'clock or a quarter after six, leaves me at a quarter before seven, I rest for twenty-five minutes, and then dress, and I am usually in my study at 8 o'clock, giving me half an hour for work before breakfast. At nine I come back again and have my mail and then work with [my Secretary] until half past eleven, take half an hour to reach the Court, and have lunch at two o'clock - half an hour-and get home at 5 o'clock. Then I take a walk across the bridge for half an hour and reset for half an hour and use the rest of the time for work. I put in about half an hour in the evening, sometimes an hour, reading the newspapers and in reading secular books, and then go to bed at ten, hoping to get sleep before eleven. If I can only keep this up, I hope I can get through this year as I did last year.

Letter from WHT to Mrs. Frederick J. Manning (Oct. 23, 1927) (Taft papers). See Letter from WHT to Robert A. Taft (Oct. 23, 1927) (Taft papers).

36. Letter from WHT to Mrs. Frederick J. Manning (Nov. 20, 1927) (Taft papers). Taft also reported that " $[\mathrm{m}] \mathrm{y}$ blood pressure has been higher than the doctor likes and higher than I like it, especially in what is called the diastole. My blood pressure is from 170 to 180 in the systole, and about 120 in the diastole. 170 to 180 in the systole is not excessive. It is probably normal for me. It is the diastole that is high." Id.

37. Letter from WHT to Charles P. Taft II (Nov. 25, 1928) (Taft papers).

38. Letter from WHT to Mrs. Frederick J. Manning (Dec. 16, 1928) (Taft papers).

39. Letter from WHT to J.M. Dickinson (Dec. 12, 1928) (Taft papers). "The work of the Court not so much in writing opinions as in getting ready for Conferences grows heavier and heavier. I feel tired over it and suffer from a lack of quickness of comprehension, which has not heretofore troubled me much." Id. At the beginning of 1929, Van Devanter wrote his sister that "[t]he Chief Justice's health is such that he will retire when he can, which will be in 1931." Letter from WVD to Mrs. John W. Lacey (Feb. 12, 1929) (Van Devanter papers). In that same letter, Van Devanter reports that

Mr. Justice McReynolds will certainly retire when he can, which will be in

1932. He would retire now if he could. Mr. Justice Sutherland is not in good 
collapse, he remarked to his brother that "I am older and slower and less acute and more confused. However, as long as things continue as they are, and I am able to answer in my place, I must stay on the Court in order to prevent the Bolsheviki from getting control."40

I have recounted Taft's deteriorating health in such detail because it forms an essential backdrop for appreciating Taft's performance in his three roles on the Court. Remarkably, Taft's vigor as a reformer and as an outwardly-facing Chief Justice did not diminish during the decade of his service. He continued energetically to press for useful legislative reform and to expand and innovate the newly minted role of Chief Justice as "chief executive" of the federal legal system.

But Taft's internal leadership of the Court did noticeably decline. He became less crisp in his grasp and presentation of certiorari petitions. ${ }^{41} \mathrm{He}$ became less proactive in steering the Court to avoid controversial opinions. Taft's previously massive output as a Justice declined during the Term following his 1924 heart attack, and it began a more protracted and irreversible slide after his 1926 heart attack, as can be seen in Figures 2 and 3. In later years, Taft's opinions also grew less cogent. ${ }^{42}$ Figure 4 shows that Taft was always a relatively prolix writer, but Figure 5 demonstrates that his opinions grew even lengthier after his 1926 heart attack. ${ }^{43}$ Taft's voting also grew less independent, as Figure 6 illustrates. Brandeis observed to Frankfurter shortly after Taft's retirement that "[ $\mathrm{t}]$ he truth is that Taft for some time had really lost his grip and V.D. and Pierce Butler and [James C.] McReynolds were running him. In addition to his being with them in their desires, they were with him in some of his own independent foolishness." ${ }^{44}$

health and will certainly retire when he can which will be in 1932. I will be 70 in April and unless there is a great change for the better in Dollie's condition I shall retire during the year. I am making no public announcement but my mind is becoming pretty well fixed on retirement.

Id.

40. Letter from WHT to Horace D. Taft (Nov. 14, 1929) (Taft papers).

41. Letter from LDB to Felix Frankfurter, Justice, U.S. Supreme Court [hereinafter FF] (May 30, 1930), in "HALF Brother, Half SoN": THE LETTERS OF LOUIS D. BRANDEIS TO FELIX FrANKFURTER 394, 431 (Melvin I. Urofsky \& David W. Levy eds., 1991) [hereinafter BRANDEIS FRANKFURTER CORRESPONDENCE].

42. See, e.g., Carson Petroleum Co. v. Vial, 279 U.S. 95 (1929); London Guarantee \& Accident Co. v. Indus. Accident Comm'n of Cal., 279 U.S. 109 (1929).

43. The slight relative decline in the page length of Taft's opinions in the 1927, 1928, and 1929 Terms is likely explained by the fact that Taft assigned himself less strenuous opinions as his health failed.

44. Letter from LDB to FF (May 30, 1930), in BRANDEIS FRANKFURTER CORRESPONDENCE, supra note 41, at 431. 
Figure 2. Number of Full Opinions by Each Justice, by Term

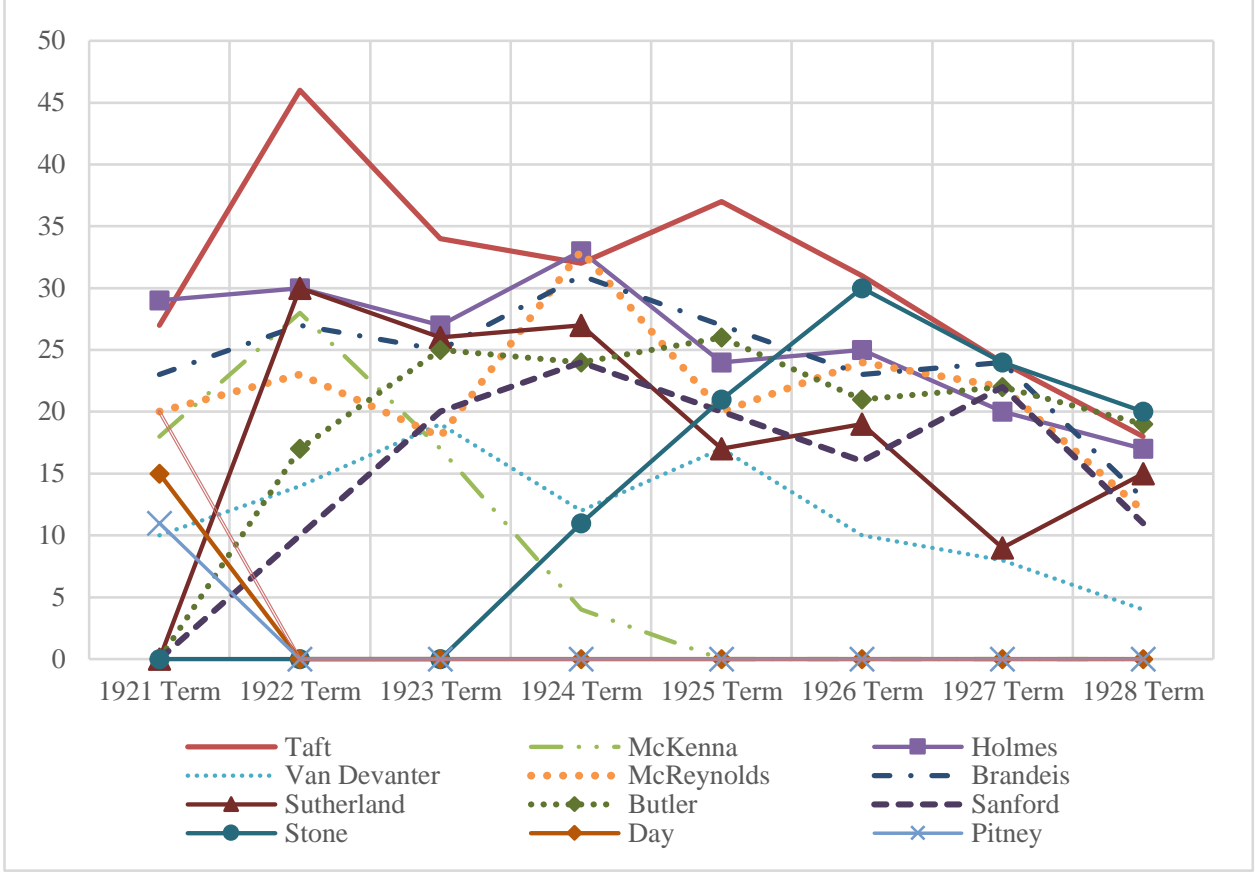

Figure 3. Percentage of Court's Full Opinions Written by Each Justice

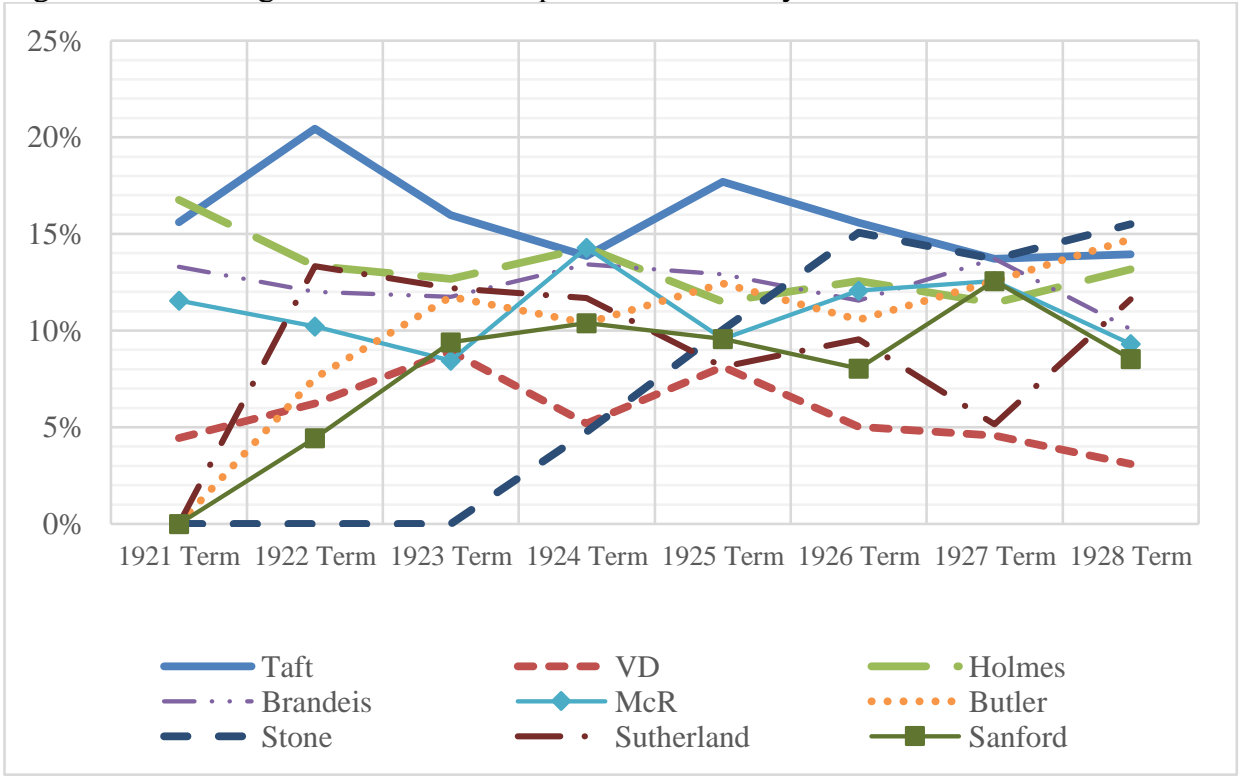


Figure 4. Average Number of Pages of a Unanimous Opinion by Author, 1921-28 Terms

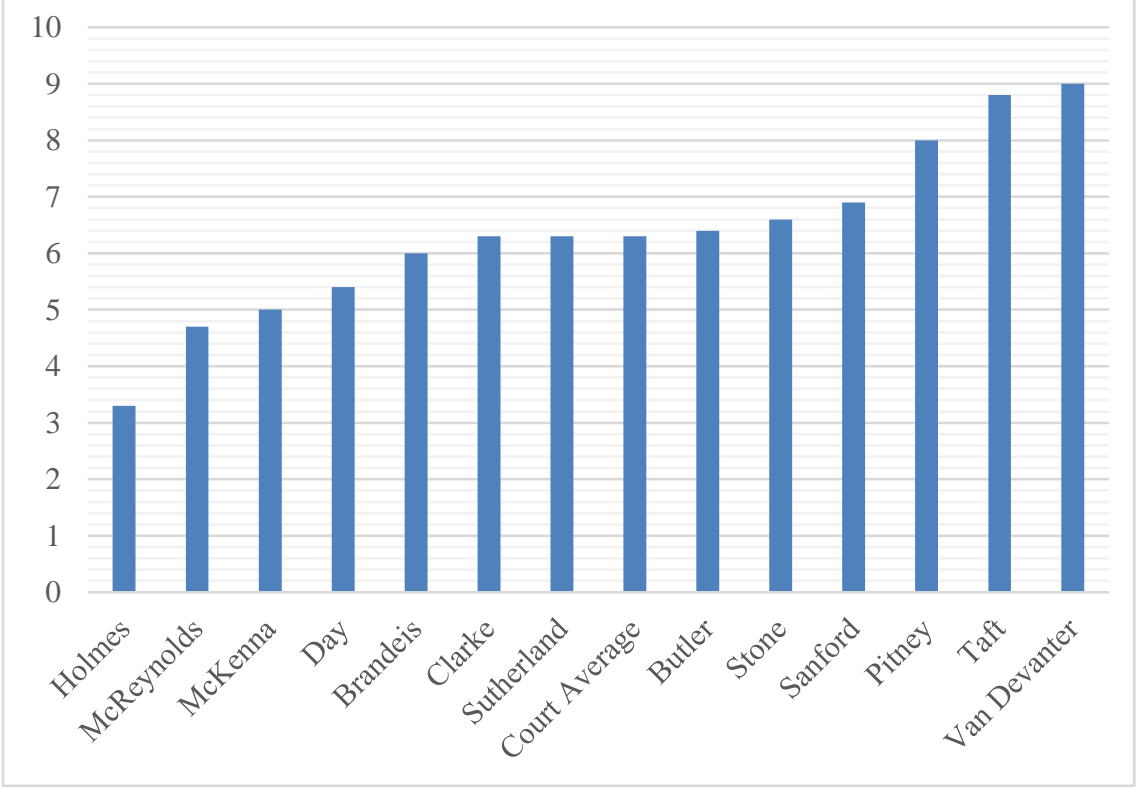

Figure 5. Average Number of Pages in Unanimous Taft Opinions by Term

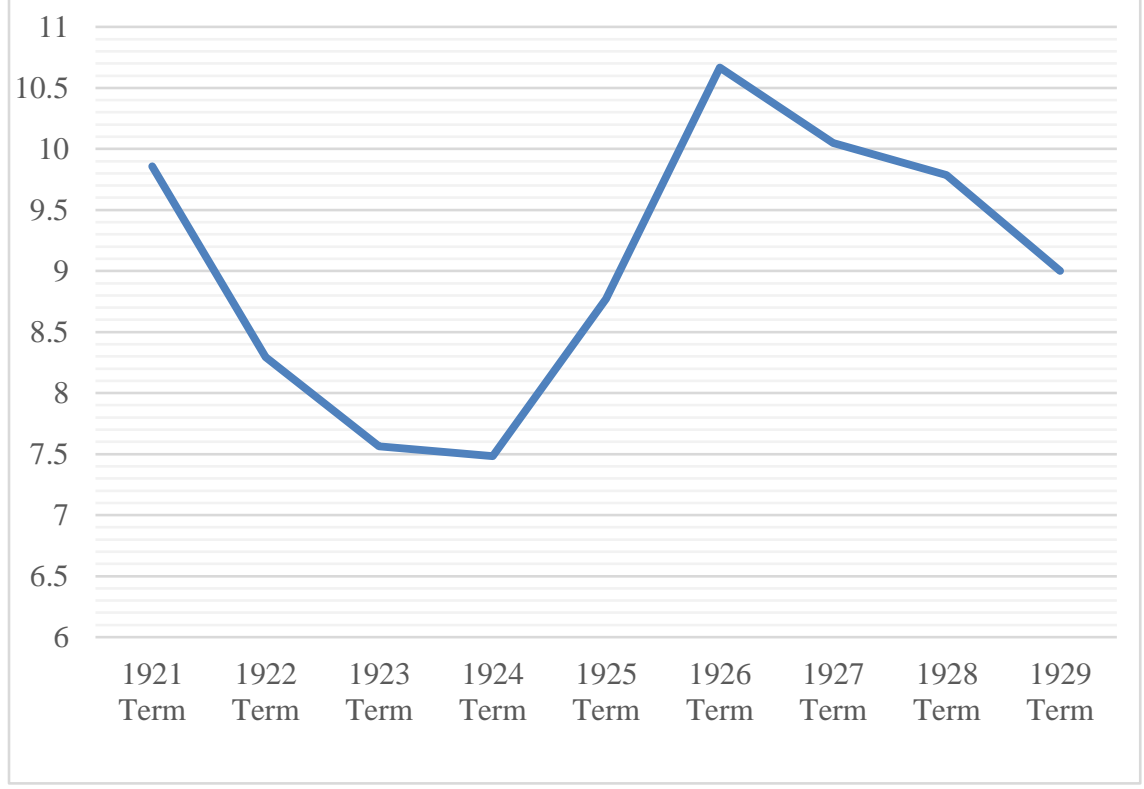


Figure 6. Number of Cases in a Term that Taft Does Not Author or Join the Majority Opinion

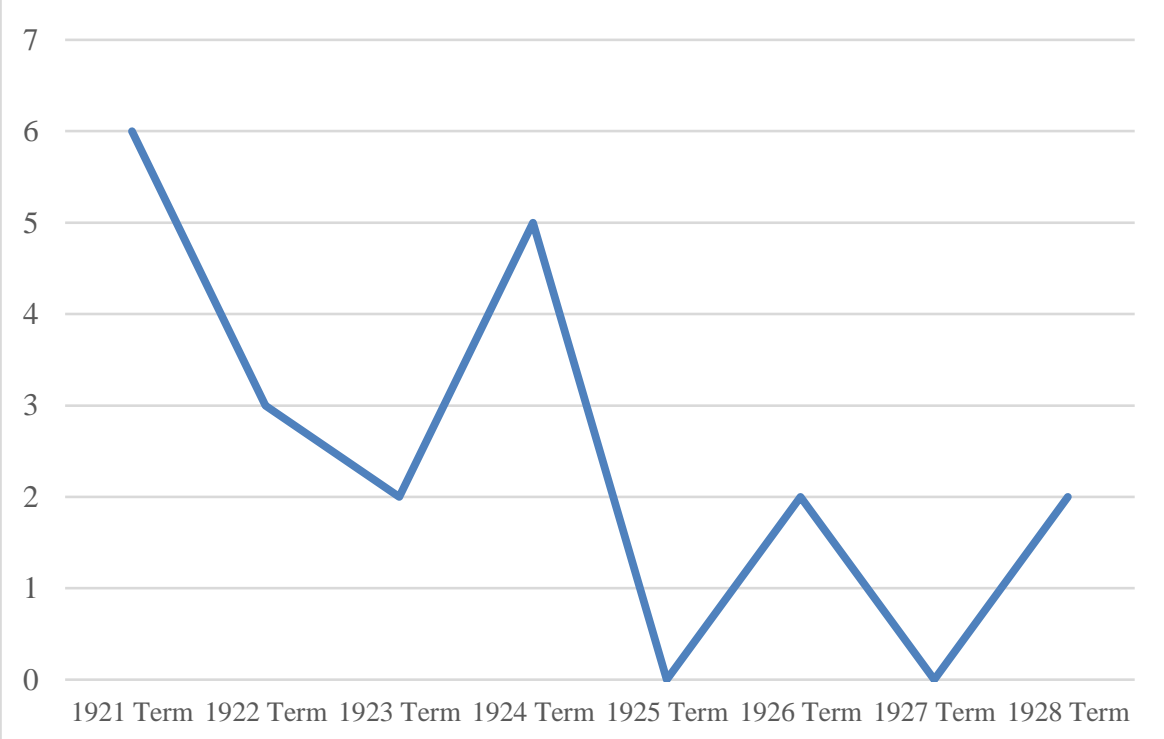

\section{TAFT AS A JUSTICE}

During Taft's first years on the Court, he inhabited the role of Justice with a strong independence of mind. From 1892-1900, Taft had been a well-respected and highly influential Senior Circuit Court judge of the Sixth Circuit. ${ }^{45}$ His famous opinion in United States $v$. Addyston Pipe \& Steel Co. ${ }^{46}$ was thought at the time to contain "the most thorough exposition in the American reports of the law relating

45. As Holmes wrote to Laski, Taft "did well as a judge." See Letter from Oliver Wendall Holmes, Justice, U.S. Supreme Court [hereinafter OWH], to Harold Laski (July 12, 1921), in Holmes-LASKI LetTERS: THE CORRESPONDENCE OF MR. Justice Holmes and Harold J. LASki 346 (Mark DeWolfe Howe ed., 1953) [hereinafter HOLMES-LASKI CORRESPONDENCE]. Holmes was suspicious, however, because "according to the papers," Taft had said that becoming Chief Justice was "the ambition of his life. I think I wrote what I thought of that kind of ambition as against the aspiration to touch the superlative in one's work. The last I do not expect (between ourselves) from Taft." Id.

46. 85 F. 271 (6th Cir. 1898). 
to restraint of trade. ${ }^{{ }^{47}}$ His notorious decision in the Phelan case ${ }^{48}$ had laid the legal foundations for controlling labor unions by enjoining strikes to enforce the Sherman Anti-Trust Act and to protect the public welfare. ${ }^{49}$ Taft knew how to write punchy and effective judicial decisions when he wanted to.

In his early years on the Court, Taft was torn between his drive toward managerial effectiveness, which was essentially progressive in its nature, and his innate constitutional conservatism. An exchange with Brandeis during Taft's first Term well captures the ambiguous complexities of Taft's jurisprudence.

In United States v. Moreland ${ }^{50}$ the Court was required to decide whether the conviction of a defendant who had been charged in juvenile court by information for failing to provide for the maintenance of his minor children and sentenced to the workhouse at hard labor for six months should be reversed because it violated the Fifth Amendment. The Amendment requires that " $[\mathrm{n}] \mathrm{o}$ persons shall be held to answer for a capital, or otherwise infamous crime, unless on presentment or indictment of a grand jury." In Moreland, the Court held that confinement "at hard labor inflicted an infamous punishment" and hence required a grand jury indictment. ${ }^{51}$

Brandeis dissented, joined by Taft and Oliver Wendall Holmes, on the grounds that "the dominant purpose" of the District of Columbia workhouse was "not punishment, but rehabilitation"; that the "compulsory labor" at issue was in fact "compulsory education" which occurred "in healthful and attractive surroundings"; that "at the time of the adoption of the Constitution and since," confinement "at hard labor in a work house or house of correction did not imply

47. ProceEdings OF THE BAR AND OfFicers OF THE SuPREME COURT OF THE UNITED STATES IN MEMORY WILliam HowARD TAFT, 285 U.S. V, XXIX-XXX (1930) [hereinafter PROCEEDINGS].

48. Thomas v. Cincinnati, N.O. \& T.P. Ry. Co., 62 F. 803 (C.C.S.D. Ohio 1894).

49. See Alpheus T. Mason, The Labor Decisions of Chief Justice Taft, 78 U. PA. L. REv. 585, 602 (1930). During his campaign for President, Taft was branded as "the father of injunctions." Taft Says He Is Sure of Election, N.Y. TimEs, Oct. 2, 1908, at 3. Taft responded with "his well known comment: 'To be known as the inventor of government by injunction is not a valuable political asset." Comments of Arthur C. Denison, in ProceEdings, supra note 47, at XII. See William Howard Taft, Judicial Decisions as an Issue in Politics, 33 MCCLURE's MAG. 201 (No. 2) (1909).

50. 258 U.S. 433 (1922).

51. Id. at 439. The result of the decision was to make "it impossible for the Juvenile Court of the District of Columbia to punish for non-support." Charles G. Ross, Decision of U.S. Supreme Court Holding Sentence at Hard Labor Is an "Infamous Punishment", St. Louis Post-DisPatch, Apr. 20, 1922, at 17. 
infamy" but was used for "offenses not deemed serious"; that "hard labor regularly pursued and productively employed" was an instrument for "reform and rehabilitation" which affirmed "the dignity of labor" and was a "means of restoring and giving self-respect"; and that the meaning of "infamous crimes" in the Fifth Amendment should be interpreted "in harmony with conditions and opinion prevailing from time to time." 52

In the original draft of his dissent, after referring to the need for a contemporary interpretation of the Fifth Amendment, Brandeis had written:

Our Constitution is not a strait-jacket. It is a living organism. As such it is capable of growth - of expansion and of adaption to new conditions. Growth implies changes political, economic and social. Growth which is significant manifests itself rather in intellectual and moral conceptions than in material things. Because our Constitution possesses this quality of adaption, it has endured as the fundamental law of an ever developing people..$^{53}$

Upon receiving Brandeis's draft, Taft objected to these sentences. Taft wrote that

they are certain to be used to support views that I could not subscribe to. Their importance depends, as old Jack Bunsby used to say, on their application, and I fear that you and I might differ as to their application. I object to them because they are unnecessary here. It seems to me you have sufficiently demonstrated that the expression "hard labor" was used with respect to bridewells and workhouses quite far back, not to mean the hard labor in the penitentiary, which is infamous, but hard labor in a place where such labor is not infamous. . . . Now it is possible-I have felt that way myself sometimes - that these particular sentences constitute the feature of the opinion that you most like, and therefore that you don't care to eliminate them. If not, I can write a short concurring opinion, avoiding responsibility for those words, and yet availing myself of your demonstration of the innocuous character of the words in question when they occur in respect to punishment not in the penitentiary. ${ }^{54}$

Brandeis replied to Taft, "I believe strongly in the view expressed in the last five sentences, but I agree with you that they are not necessary

52. Moreland, 258 U.S. at 441-51 (Brandeis, J., dissenting). Holmes returned the initial draft of Brandeis's dissent with the comment, "A sockdologer. I am with you with both feet." (Brandeis papers). He later added, "I think you have sockdologized our sensitive brother so fully that I marvel that he is not left alone." (Brandeis papers). The majority opinion was written by McKenna. There was ongoing tension between Holmes and McKenna.

53. (Brandeis papers).

54. Letter from WHT to LDB (Mar. 30, 1922) (Taft papers). 
and I am perfectly willing to omit them." ${ }_{55}$ Taft then concurred in Brandeis's recirculated opinion, commenting, "Your historical references ought to satisfy any reasonable person that hard labor is not a hard and fast expression but is one the effect of which is to be explained by the context and the circumstances. This is the controlling consideration with me." 56

The exchange between Taft and Brandeis is noteworthy for several reasons. Its tact and delicacy are striking. This is plainly a conversation between two serious men who fully understand and respect the difference between their views. Brandeis wanted to insist on the flexibility of constitutional provisions, Taft to stress their relative stability.

Yet this difference is a good deal less stark than ordinarily characterized. Not only did Taft join an opinion arguing that the Fifth Amendment should be interpreted based upon "the context and the circumstances," but he concurred with the basic thrust of Brandeis's dissent, which is that government should be empowered to control individual behavior without unduly burdensome constitutional restrictions when it does so for purposes of genuine rehabilitation, rather than for purposes of status degradation. This is a deeply progressive view of the relationship between a government and its population, and it appealed to Taft's managerial instincts.

Taft gave firm and lasting expression to these same instincts in the important and enduring opinion of Carroll v. United States, ${ }^{57}$ which authorized the warrantless search of automobiles (so long as there was probable cause), which Brandeis joined (and which incidentally also nicely illustrated Taft's forceful leadership of the Court before his 1926 heart attack). ${ }^{58} \mathrm{He}$ also gave voice to these

55. Letter from LDB to WHT (Mar. 30, 1922) (Taft papers).

56. (Brandeis papers).

57. See 267 U.S. 132 (1925).

58. Carroll had originally been assigned to McReynolds to affirm the warrantless search of a car carrying illegal liquor. Letter from WHT to Horace D. Taft (Mar. 1, 1925) (Taft papers); Williams, supra note 1, at 47. Butler's docket book indicates that Butler, Sutherland, and Sanford had initially voted to reverse the judgment below and exclude the evidence. BUTLER DOCKET BOOK, 1923 TERM, at 332. "In the course of writing the opinion, McReynolds changed his mind and concluded that the judgment should be reversed. The case was then reargued . ..."Williams, supra note 1 , at 47 . On the initial vote, the decision was to reverse, but Taft wrote his brother, "McKenna came over so that I was able to assign it to myself." Letter from WHT to Horace D. Taft (Mar. 1, 1925) (Taft papers); Letter from WHT to Robert A. Taft (Mar. 8, 1925) (Taft papers) ("I was once outvoted in the Conference.").

Taft understood the case in light of the managerial necessity to control automobiles, which he considered "the greatest instrument to promote immunity from 
instincts in Olmstead $v$. United States ${ }^{59}$ which authorized warrantless wiretapping. Brandeis's famous dissent in that case is prescient precisely because it anticipated how liberals in the years after Carolene Products ${ }^{60}$ would seek to craft constitutional rights to limit the prerogatives of the administrative state, the very state that

punishment for crime that we have introduced in many, many years, and we haven't as yet neutralized its effect." Letter from WHT to Horace D. Taft (Nov. 16, 1923) (Taft papers). Taft considered "it important to establish the correct principle in respect to the search of this instrument of evil the automobile," Letter from WHT to Horace D. Taft (Mar. 1, 1925) (Taft papers), because he wanted "a useful means of rendering the prosecution of crimes through automobiles more possible." Letter from WHT to Henry W. Taft (Apr. 3, 1925) (Taft papers). Taft steeled himself "to write an opinion" establishing "some rather new principle . . . against a vigorous opposition." Letter from WHT to Charles P. Taft II (Dec. 22, 1924) (Taft papers). He was "very doubtful of my majority after I get the opinion written. I am not at all sure that I can hold it." Letter from WHT to Robert A. Taft (Dec. 22, 1924) (Taft papers). That Van Devanter broke with his conservative colleagues and remained steadfast in his vote to affirm the conviction reflects not only his personal loyalty to Taft, but also the pragmatic instincts that he often shared with Taft.

On December 22, 1924, Van Devanter wrote Taft a memorandum containing suggested arguments for the opinion. "The more I think of the case," he said, "the more I think the view we entertain is right and that the other view would be productive of harmful results in many ways." Letter from WVD to WHT (Dec. 22, 1924) (Taft papers). Taft, responding to language that no longer survives, replied to Van Devanter that "I note what you say about brother Butler, and shall try to steer away from the suggestion that we are introducing any new law and new principle of constitutional construction, but only adapting old principles and applying them to new conditions created by the change in the national policy which the 18th Amendment represents." Letter from WHT to WVD (Dec. 23, 1924) (Taft papers).

Oddly, Taft wrote his brother on December 26 that "Brandeis was with me very strongly before the summer vacation, but he went up to Cambridge and must have communed with Frankfurter and that crowd, and he came back with a notice to me that he was going to change his vote." Letter from WHT to Horace D. Taft (Dec. 26, 1924) (Taft papers). There is no indication in the Brandeis papers that Brandeis was preparing any dissent, however, and indeed on January 15 there is a memorandum by Brandeis to Taft containing useful citations for the opinion. Letter from LDB to WHT (Jan. 15, 1925) (Taft papers). Three months later Taft wrote his brother that he had been working on the opinion "since October. I brought in an opinion the last of the year. I succeeded in bringing over all but McR and Sutherland. McR has written a dissent and a strong one. I don't know whether Sutherland will go with him or not. Van Devanter thinks not. At any rate we carry the day and I am rejoiced." Letter from WHT to Horace D. Taft (Mar. 1, 1925) (Taft papers). In the end, both McReynolds and Sutherland dissented. Butler and Sanford, no doubt for institutional reasons, were persuaded to join the majority opinion.

59. See 277 U.S. 438 (1928). For a good illustration of Taft's managerial instincts in the context of criminal law, which had been honed by his years as a colonial administrator, see William H. Taft, The Administration of Criminal Law, 15 YALE L.J. 1, 10 (1905).

60. United States v. Carolene Prods. Co., 304 U.S. 144, 152 n.4 (1938). 
progressives in the years before World War II were so concerned to foster.

In his years on the Court, Taft as a reformer would constantly seek ways to implement innovations that would be "progressive and helpful," 61 while as a Justice he adopted a jurisprudence that was explicitly pragmatic and purposeful. ${ }^{62} \mathrm{He}$ strongly supported executive prerogatives ${ }^{63}$ and embraced administrative agencies. ${ }^{64} \mathrm{He}$ usefully articulated the nature of the delegation power ${ }^{65}$ in a manner that included an acute distinction between vagueness in rules addressed to administrative officials and vagueness in rules addressed to the general public. ${ }^{66}$

Nowhere was Taft's practical side more apparent than in his majestic opinions upholding federal commerce power as "fitted" to "the real and practical essence of modern business growth." 67 In an

61. Letter from WHT to Henry W. Taft (May 18, 1926) (Taft papers).

62. See, e.g., Gorham Mfg. Co. v. Wendell, 261 U.S. 1, 4 (1923); Colgate v. United States, 280 U.S. 43 (1929); ICC v. United States ex rel. Los Angeles, 280 U.S. 52 (1929); Richmond Screw Anchor Co. v. United States, 275 U.S. 331 (1928); United States v. Murray, 275 U.S. 347 (1928); Compania Gen. De Tabacos de Filipinas v. Collector of Internal Revenue, 275 U.S. 87 (1927); FTC v. Klesner, 274 U.S. 145 (1927); United States v. Stone \& Downer Co., 274 U.S. 225 (1927); Woodbridge v. United States, 263 U.S. 50 (1923).

63. See, e.g., Luckenbach S.S. Co. v. United States, 280 U.S. 173 (1930); United States v. Jackson, 280 U.S. 183 (1930); Myers v. United States, 272 U.S. 52 (1926); Ex parte Grossman, 267 U.S. 87 (1925); McConaughey v. Morrow, 263 U.S. 39 (1923).

64. See, e.g., Boston v. Jackson, 260 U.S. 309 (1922); FTC v. Klesner, 274 U.S. 145 (1927); FTC v. Curtis Publ'g Co., 260 U.S. 568, 582-83 (1923) (Taft, C.J., doubting).

65. J.W. Hampton, Jr. \& Co. v. United States, 276 U.S. 394, 409 (1928). See Whitman v. Am. Trucking Ass'ns, Inc., 531 U.S. 457, 472 (2001).

66. "The rule as to a definite standard of action is not so strict in cases of the delegation of legislative power to executive boards and officers." Mahler v. Eby, 264 U.S. 32, 41 (1924).

67. Bd. of Trade of Chi. v. Olsen, 262 U.S. 1, 35 (1923). In Olsen the Court, over the dissents of McReynolds and Sutherland, upheld the constitutionality of the Grain Futures Act of 1922, 42 Stat. 998, which regulated the interstate market in grain. The year before, in Hill v. Wallace, 259 U.S. 44 (1922), Taft, writing for a virtually unanimous court, had found the Future Trading Act, 42 Stat. 187, unconstitutional because it sought to regulate mere contracts for the sale of grain. Taft had at that time broadly hinted that "[a] reading of the act makes it quite clear that Congress sought to use the taxing power to give validity to the act. It did not have the exercise of its power under the commerce clause in mind, and so did not introduce into the act the limitations which certainly would accompany and mark an exercise of the power under the latter clause." Hill, 259 U.S. at 68-69. Taking the hint, Congress promptly enacted the Grain Futures Act with appropriate jurisdictional limitations. The case is a good demonstration of Taft's masterly guidance of the Court's decision-making. 
opinion upholding the Packers and Stockyards Act of 1921, Taft affirmed Congress's power to regulate the "streams of commerce from one part of the country to another, which are ever flowing," without a "nice and technical inquiry into the noninterstate character of some of its necessary incidents and facilities, when considered alone and without reference to their association with the movement of which they were an essential but subordinate part." 68

Whatever amounts to a more or less constant practice, and threatens to obstruct or unduly to burden the freedom of interstate commerce is within the regulatory power of Congress under the commerce clause, and it is primarily for Congress to consider and decide the fact of danger and meet it. This court will certainly not substitute its judgment for that of Congress in such a matter unless the relation of the subject to [the] interstate commerce and its effect upon it are clearly nonexistent. ${ }^{69}$

Taft circulated to the Court a memorandum describing the convoluted background of Hill:

On the question whether [the Future Trading Act] could be sustained as a taxing act, the vote stood 7 to 1 , Justice McKenna casting the negative vote, and Justice Brandeis not voting. Later we took a vote as to whether the act could be sustained as a regulation of interstate commerce. At first, by a vote of 5 to 4 , it was held that it could not be sustained. Later there was a change, and by a vote of 5 to 3 , Justice Brandeis not voting, its validity as a regulation of interstate commerce was sustained. On a close examination of the case, the law and the record, I have reached the conclusion stated in this [circulated] opinion, namely that ... the law is invalid as a taxing law, and that it can not be sustained as a valid regulation of interstate commerce.

Letter from WHT to WVD (May 12, 1922) (Van Devanter papers); see Letter from WHT to LDB (May 12, 1922) (Taft papers). Not only did Taft's resolution of the case carry the Court-Brandeis called it "strong and convincing"-but it eventually created the space for the more finely crafted Grain Futures Act to pass constitutional muster. Letter from LDB to WHT (May 12, 1922) (Taft papers). As Taft pointed out in Olsen, "[t]he Grain Futures Act which is now before us differs from the Future Trading Act in having the very features the absence of which we held in the somewhat carefully framed language of the foregoing prevented our sustaining the Future Trading Act. As we have seen in the statement of the case, the act only purports to regulate interstate commerce and sales of grain for future delivery on boards of trade because it finds that by manipulation they have become a constantly recurring burden and obstruction to that commerce." 262 U.S. at 32-33.

68. Stafford v. Wallace, 258 U.S. 495, 519 (1922).

69. Id. at 521. Upon receiving the draft of Taft's opinion, Holmes wrote back: "Admirable and big." (Taft papers). He subsequently observed to Frederick Pollock that Taft's opinion "expressed the movement of interstate commerce in a large and rather masterly way." Letter from OWH to Frederick Pollock (May 21, 1922), in 2 Holmes-Pollock LeTters: The CORRESPONDENCE OF Mr. Justice HOLMES AND SiR FREDERICK POLlOCK, 1874-1932 96 (Mark DeWolfe Howe ed., 1942) [hereinafter 2 Holmes-Pollock CoRRESPONDENCE]; see Letter from OWH to Harold Laski (May 3, 1922), in Holmes-LASKI CORRESPONDENCE, supra note 45, at 423. McReynolds 
The same practical, regulatory instinct was fully manifest in Taft's powerful opinion for a unanimous Court in Dayton-Goose Creek Railway Co. v. United States, which upheld the constitutionality of provisions of the Transportation Act of 1920 that required railroads receiving "in excess of a fair return" to remit one half of that excess "to a general railroad revolving fund to be maintained" by the Interstate Commerce Commission to help "the weaker roads more effectively to discharge their public duties." 70 Taft invoked the authority of practical reason brusquely to dismiss the argument that the Act exceeded Congress's commerce power:

In solving the problem of maintaining the efficiency of an interstate commerce railway system which serves both the states and the nation, Congress is dealing with a unit in which state and interstate operations are often inextricably commingled. . . The combination of uniform rates with the recapture clauses is necessary to the better development of the country's interstate transportation system as Congress has planned it. The control of the excess profit due to the level of the whole body of rates is the heart of the plan. To divide that excess and attempt to distribute one part to interstate traffic and the other to intrastate traffic would be impracticable and defeat the plan. This renders indispensable the incidental control by Congress of that part of the excess possibly due to intrastate rates which, if present, is indistinguishable. ${ }^{71}$

dissented in Stafford. Before generally circulating his proposed opinion in Stafford, Taft had sent a preliminary draft to John H. Clarke and Van Devanter "because we three are very clear in our judgment, and I would like the benefit of your criticism before I send it on to other members of the Court who are more doubtful." Letter from WHT to WVD (Apr. 20, 1922) (Van Devanter papers). Clarke wrote back praising the opinion but asking whether Congress can "bring acts of the conspirators into interstate commerce if they are not otherwise there? All Congress can do is to declare that given conduct is really or essentially within such commerce $\&$ an obstruction to it $\&$ if the courts agree with this declaration of it the act must be upheld." Letter from John H. Clarke, Justice, U.S. Supreme Court [hereinafter JHC], to WHT (1922) (Taft papers). When Taft circulated his draft to all members of the Court, Brandeis returned the opinion with the comment, "[t]his is very strongly put and has converted me." (Taft papers). Brandeis's initial doubts were apparently connected to his belief that, as he commented to his daughter a propos of the case, that "[i]f we may hope to carry out our ideals in America, it will be by development through the State and local Governments. Centralization will kill —only decentralization of social functions can help. In the 19th Century nationalization was the keynote \& the 20th should bring local development in States \& cities." Letter from LDB to Susan Brandeis (May 18, 1922), in THE FAmily LeTters OF Louis D. BRANDEIS 379-80 (Norman, Melvin I. Urofsky and David W. Levy eds., 2002).

70. 263 U.S. 456, 476-77, 484 (1924).

71. Id. at 485 . Taft also ruthlessly dismissed the claim that the redistribution of excess profits was a taking of the railroads' property: 
The practical, managerial side of Taft reached its apogee in his remarkable dissent in Adkins v. Children's Hospital of the District of Columbia,${ }^{72}$ in which the Court, speaking through Sutherland, found a minimum wage law for women unconstitutional. In language that sounded distinctly Holmesian in its generous appreciation of the reach of police power, Taft argued:

The boundary of the police power beyond which its exercise becomes an invasion of the guaranty of liberty under the Fifth and Fourteenth Amendments to the Constitutions is not easy to mark. Our court has been laboriously engaged in pricking out a line in successive cases. We must be careful, it seems to me, to follow that line as well as we can, and not to depart from it by suggesting a distinction that is formal rather than real.

Legislatures in limiting freedom of contract between employee and employer by a minimum wage proceed on the assumption that employees, in the class receiving least pay, are not upon a full level of equality of choice with their employer and in their necessitous circumstances are prone to accept pretty much anything that is offered. They are peculiarly subject to the overreaching of the harsh and greedy employer. The evils of the sweating system and of the long hours and low wages which are characteristic of it are well known. Now, I agree that it is a disputable question in the field of political economy how far a statutory requirement of maximum hours or minimum wages may be a useful remedy for these evils, and whether it may not make the case of the oppressed employee worse than it was before. But it is not the function of this court to hold congressional acts invalid simply because they are passed to carry out economic views which the court believes to be unwise or unsound.

Legislatures which adopt a requirement of maximum hours or minimum wages may be presumed to believe that when sweating employers are prevented from paying unduly low wages by positive law they will continue their business, abating that part of their profits, which were wrung from the necessities of their employees, and will concede the better terms required by the law, and that while in individual cases, hardship may result,

We have been greatly pressed with the argument that the cutting down of income actually received by the carrier for its service to a so-called fair return is a plain appropriation of its property without any compensation; that the income it receives for the use of its property is as much protected by the Fifth Amendment as the property itself. The statute declares the carrier to be only a trustee for the excess over a fair return received by it. Though in its possession, the excess never becomes its property, and it accepts custody of the product of all the rates with this understanding. It is clear, therefore, that the carrier never has such a title to the excess as to render the recapture of it by the government a taking without due process.

Id. at 484 .

72. See Adkins v. Children's Hosp. of the Dist. of Columbia, 261 U.S. 525, 562 (1923) (Taft, C.J., dissenting). 
the restriction will inure to the benefit of the general class of employees in whose interest the law is passed, and so to that of the community at large. ${ }^{73}$

In contrast to Holmes, however, who religiously separated his political conservatism from his jurisprudence, Taft let his conservative ideology seep deeply into his legal thinking. Although Taft pursued moderately progressive policies, his break with Theodore Roosevelt in 1912 had made him distrustful of excess reformist zeal. ${ }^{74} \mathrm{He}$ became alarmed when he suspected that the "leviathan, the People" were aroused with "a momentum" that would carry "their earnestness and just indignation beyond the median and wise line." 75 In such moments he called upon the Constitution, which he characterized in a phrase Holmes would never consider using, as "the ark of our covenant," 76 to

73. Id. at 562-63. As President, Taft had conceded that courts "have unduly broadened constitutional restrictions in order to invalidate useful statutes, or have given such statutes a wrong construction. Indeed, I do not hesitate to say that I do not concur in the reasoning of certain courts of last resort as to the constitutional validity of certain social reform statutes, and I am very anxious that the remedies proposed in these statutes should be given effective operation." William H. Taft, The Judiciary and Progress, S. Doc. No. 408, 62nd Cong, 2d Sess. 5 (Mar. 8, 1912). See Edward Hartnett, Why Is the Supreme Court of the United States Protecting State Judges from Popular Democracy, 75 TEX. L. REV. 907, 949-56 (1997) (arguing that Taft supported the Act of December 23, 1914, 38 Stat. 790, which authorized Supreme Court review of state court decisions against the validity of a state statute or authority claimed to be repugnant to the Constitution, in order to "defuse the pressure for radical reform" like the recall of judges and judicial decisions).

74. See Doris Kearns GoOdwin, The Bully Pulpit: Theodore Roosevelt, William Howard Taft, and the Golden Age of Journalism 704 (2013).

75. William Howard Taft, The Anti-Trust Act AND the Supreme CourT 34 (1914).

76. Bailey v. Drexel Furniture Co., 259 U.S. 20, 28, 37 (1922). In Bailey, Taft, writing for a unanimous Court, invalidated the Child Labor Tax Law, which attempted to use the Taxing power to regulate child labor in a manner held unconstitutional under the Commerce Clause in Hammer v. Dagenhart, 247 U.S. 251 (1918). Brandeis joined Bailey, commenting to Taft, "A very good opinion. . . . You have made this clear $\&$ forceful $\&$ have done all that can be done to distinguish the earlier cases." (Taft papers). Writing to Frankfurter to explain his votes in Bailey and Hill v. Wallace, 259 U.S. 44 (1922), Brandeis commented that

[t]he N[ew] R[epublic], The Survey \& like periodicals should not be permitted to misunderstand yesterday's decision on The Child Labor and Board of Trade cases, \& should be made to see that holding these Acts void is wholly unlike holding invalid the ordinary welfare legislation.

That is - that we here deal

(1) With distribution of functions between State \& Federal Governments

(2) With the attempt at dishonest use of the taxing powers.

Letter from LDB to FF (May 16, 1922), in BRANDEIS FrANKFuRTER CORRESPONDENCE, supra note 41 , at 100-01. 
curb democratic enthusiasm and maintain what Taft regarded as an appropriate respect for fundamental values. It was for this reason that in Truax v. Corrigan, ${ }^{77}$ decided just four months before Moreland, Taft proclaimed that "[t]he Constitution was intended-its very purpose was - to prevent experimentation with the fundamental rights of the individual." 78

Truax, which involved an Arizona statute restricting judicial injunctions in labor cases ${ }^{79}$ touched an area where Taft believed that

77. 257 U.S. 312 (1921).

78. Id. at 338. Taft wrote Austen Fox, the lawyer who had led the assault against Brandeis's judicial confirmation, that Taft was glad that Fox approved "the opinion . . . in Truax v. Corrigan. The disposition to regard the Constitution as something that does not mean any limitation at all is a dangerous one, and I rejoice that we had a majority of the Court that took the more conservative view." Letter from WHT to Austen G. Fox (Jan. 31, 1922) (Taft papers). To G.N. Harrison, Taft wrote that "I deprecate the latitudinarian view of the Constitution which some of our brethren seem to have in certain cases." Letter from WHT to G.N. Harrison (Feb. 13, 1922) (Taft papers).

79. Paragraph 1464 of the Revised Statutes of Arizona of 1913 (Civ. Code) proscribed labor injunctions that prohibited

any person or persons from terminating any relation of employment, or from ceasing to perform any work or labor, or from recommending, advising, or persuading others by peaceful means so to do; or from attending at or near a house or place where any person resides or works, or carries on business, or happens to be for the purpose of peacefully obtaining or communicating information, or of peacefully persuading any person, to work or to abstain from working; or from ceasing to patronize or to employ any party to such dispute; or from recommending, advising, or persuading others by peaceful means so to do....

Truax, 257 U.S. at 322. The Arizona Supreme Court had interpreted the statute to prohibit the issuance of an injunction against picketing that, in Taft's view, constituted a "palpable" wrong:

The patrolling of defendants immediately in front of the restaurant on the main street and within five feet of plaintiffs' premises continuously during business hours, with the banners announcing plaintiffs' unfairness; the attendance by the picketers at the entrance to the restaurant and their insistent and loud appeals all day long, the constant circulation by them of the libels and epithets applied to employees, plaintiffs, and customers, and the threats of injurious consequences to future customers, all linked together in a campaign were an unlawful annoyance and a hurtful nuisance in respect of the free access to the plaintiffs' place of business. It was not lawful persuasion or inducing. It was not a mere appeal to the sympathetic aid of would-be customers by a simple statement of the *fact of the strike and a request to withhold patronage. It was compelling every customer or would be customer to run the gauntlet of most uncomfortable publicity, aggressive and annoying importunity, libelous attacks, and fear of injurious consequences, illegally inflicted, to his reputation and standing in the community. 
the demos was systematically encroaching on sacred constitutional rights. The question of the labor injunction had arisen in Taft's 1908 campaign for the presidency, when there had been an effort to insert a plank in the Republican Party platform limiting equitable remedies in labor contexts. Taft at the time wrote his chief strategist that he "would 'rather cut my hand off' than take from the courts their power to protect property." ${ }^{80}$ In his first Inaugural Address as President, Taft had announced that his "convictions are fixed" with regard "to the power of the federal courts to issue injunctions in industrial disputes":

Take away from the courts, if it could be taken away, the power to issue injunctions in labor disputes, and it would create a privileged class among the laborers, and save the lawless among their number from a most needful remedy available to all men for the protection of their business against lawless invasion. The proposition that business is not a property or pecuniary right which can be protected by equitable injunction is utterly without foundation in precedent or reason. ${ }^{81}$

In Truax, Taft used the Equal Protection Clause to strike down the Arizona statute on the grounds that it created arbitrary class privilege. $^{82}$

Id. at $327-28$.

80. Henry F. Pringle, 1 The Life And Times of William Howard TaFt: A BIOGRAPHY 350 (1939).

81. William H. Taft, Inaugural Address (March 4, 1909), in InAUgural AddREsSes of THE Presidents of THE United StATes 197 (1965). See Taft, Judicial Decisions, supra note 49, at 201 (discussing Taft's labor decisions).

82. Taft had initially assigned the opinion to Mahlon Pitney. Upon studying the case, however, and upon receiving a memorandum on the subject by Brandeis, Pitney changed his mind and circulated a memorandum supporting the constitutionality of the Arizona statute. Taft was then forced to take over the case and author an opinion for five Justices. To Taft's circulated opinion, Van Devanter responded, "I most sincerely congratulate you on so wholesome an outcome in a difficult case. The dissent nicely serves to emphasize the points of your decision. They neither shake your reasoning nor raise any doubt of the propriety of its application." Day wrote, "Certainly. No other view is permissible after this clear demonstration of the right one," while McKenna returned, "Good work. Most heartily." (Taft papers). Holmes dissented separately, as did Brandeis. Clarke joined Pitney's dissent, writing Brandeis, "I am sorry I can't go with you in this but your dissent is much too discursive \& expanded to please me. I shall concur in the dissent of Pitney." (Brandeis papers). Holmes wrote Laski that "[t]he C.J. disappointed us after a good start, as it seemed, in what we think the right direction in an earlier case. I thought this performance rather spongy." Letter from OWH to Harold Laski (Jan.15, 1922), in HOLMES-LASKI CORRESPONDENCE, supra note 45, at 398. Brandeis personally considered Taft's use of the Equal Protection Clause to be "dreadful," Brandeis-Frankfurter Conversations, supra note 5, at 318, and he believed that the outcome in Truax had been driven primarily by political prejudices. "Court is malleable almost on everything except trade unions. There its prejudices become active." Id. at 322. In his view, the case 
As a politician and as a Justice, Taft was concerned to constrain what he regarded as undue progressive assaults on property. In one of his last speeches as President, Taft addressed his fellow Republicans about his devastating loss in the 1912 election. He seemed almost reconciled to the victory of "our old-time opponent, the Democratic Party," 83 but reserved his ire for Theodore Roosevelt and the Progressive Party. ${ }^{84}$ Taft condemned "the whole program of the

illustrated Holmes's political naiveté. “After first argument of Truax case, Holmes, Clarke \& I walked home together \& Holmes said: 'Well, at least in this case no one will vote for reversal.' And I said: 'We'll be lucky if we can sustain it five to four.' Holmes has no realization of what moves men - he is as innocent as a girl of sixteen is supposed to have been. And most of the time it doesn't matter in his position." Id. at 306-07.

Taft, it should be said, was prominent among conservatives for standing staunchly for the right of labor unions to exist and for the right of union members to choose their own leaders. See, e.g., Pa. R. Co. v. U.S. R.R. Labor Bd., 261 U.S. 72 (1923); Pa. R.R. Sys. \& Allied Lines Fed'n No. 90 v. Pa. R. Co., 267 U.S. 203 (1925); Hon. WiLliam H. TAFT Discusses IsSuANCE of InJUNCTIONS IN LABOR Disputes 3 (First National Bank Building, Columbus, Ohio 1908) ("I believe it to be highly beneficial and entirely lawful for laborers to unite in their common interests. They have labor to sell, and if they stand together they are often able, all of them, to command better prices of their labor, or more advantageous terms of employment than when dealing singly, for the necessities of the single employee may compel him to accept any terms offered him. The accumulation of funds for the support of those who propose to enter into controversy with the employer by striking, is one of the legitimate objects of such an organization. Its members have the right to appoint officers, who shall advise them as to the course to be taken by them in their relations to their employer . ..."); WILLIAM H. Taft, Present Day Problems 248-57 (New York: Dodd, Mead \& Co. 1908); William Howard Taft, Taft Says Justice to Labor Is in Industrial Democracy, WASH. Post, April 14, 1919, at 1. Taft also took pains to ensure that not every strike that resulted in " $[t]$ he mere reduction in the supply of an article to be shipped in interstate commerce" could be charged as a violation of federal antitrust laws. United Leather Workers' Int'l Union v. Herkert \& Meisel Trunk Co., 265 U.S. 457, 471 (1924). See Coronado Coal Co. v. United Mine Workers, 268 U.S. 295 (1925); United Mine Workers of Am. v. Coronado Coal Co., 259 U.S. 344 (1922). This created some tension with the expansive "stream of commerce" conception of federal commerce power that Taft had himself articulated to sustain federal regulations. See supra notes $67-69$.

83. William Howard Taft, Address at the Banquet of the Union League Club of New York 8 (Jan. 4, 1913).

84. "We were beaten in the last election. We ran third in the race. Why is it that we gather here with so much spirit and with so little of the disappointment and humiliation supposed to accompany political disaster? Is it not that in spite of the defeat recorded at the election in November we were still victorious in saving our country from an administration whose policy involved the sapping of the foundations of democratic, constitutional, representative government, whose appeals to the people were calculated to arouse class hatred that has heretofore been the ruin of popular government, and whose contempt for the limitations of constitutional law and the 
Progressive Party" as "taking from the successful and the conferring on the unsuccessful that which the successful have earned." 85 The price of any such program, Taft declared, was nothing less than the "destruction" of "modern progress." ${ }^{86}$ It was the function of "constitutional limitations," "vindicated through courts" to prevent such a calamity. But

under the system which our progressive friends propose the limitations themselves are to be subjected to the abolishing power of a referendum, and when they are embodied and enforced in a judgment of a court they may still be lost by a referendum of the judgment to the populace in an election to determine whether the court's decision is right. Thus it is easily seen that under the progressive program the whole machinery that has been so carefully built up by the older statesmen of this country and of England to save to the individual and the minority freedom, equality before the law, the right of property, and the right to pursue happiness is to be taken apart and thrown into a junk heap and the preservation of such rights or privileges . . . is to be left to the charitable impulse of a benevolent administrator.

No one at all familiar with the principles of free government and the tendency of erring and power-loving human nature would be content to have his liberty or his right of property or his right to pursue happiness dependent upon the benevolence of anyone. ${ }^{87}$

Taft's opinions as a Justice were often the scene of struggle between, on the one hand, his attraction to benevolent and effective administration, and, on the other, his suspicion of public regulation of property ${ }^{88}$ A good example is Lehigh Valley Railway Co. v. Board of Public Utility Commissioners ${ }^{89}$ in which a railroad company appealed

guaranties of civil liberty promised chaos and anarchy in a country that has until this time been the model of individual freedom and effective popular government?" Id.

85. Id. at 11 .

86. Id.

87. Id. at $11-12$.

88. As Taft told his Republican audience, "I am greatly concerned that [popular government] shall continue and be successful in giving to the people at large the best measure of individual liberty on the one hand and the greatest practical efficacy in government on the other." Id. at 5. At root, the tension reflected Taft's commitment to using constitutional rights to protect the "individual initiative and enterprise and reward" upon which "our progress" depends, and his concomitant understanding that "elasticity of . . . constitutional restraints" was necessary so that "where men use their right of liberty or their right of property in such combination as to give them power by duress arbitrarily to control others, the liberty of the individual and his right of property are subject to reasonable governmental control." Taft Tells Minneapolitans What Constitutes True and Ideal Americanism, MinNEAPOLIS STAR TRIBUNE, Feb. 12, 1920, at 6.

89. See Leigh Valley R.R. Co. v. Bd. of Pub. Util. Comm'rs, 278 U.S. 24 (1928). 
the order of a state public utility commission requiring it to construct an overhead crossing at the cost of $\$ 324,000$. The company believed that a satisfactory crossing could be constructed for "at least $\$ 100,000$ less." ${ }^{90}$ Taft's opinion for the Court, over McReynolds' dissent, ${ }^{91}$ was almost painfully ambivalent, supporting the necessary discretion of administrators "to avoid danger to the public" signaling that " $[t]$ he protection of the Fourteenth Amendment in such cases is real, and is not to be lightly regarded." ${ }^{93}$ Although Taft was prepared to hold that the costs in the case before him were "within reasonable limits," ${ }^{4}$ he nevertheless took pains to "deprecate the impression, apparently entertained by some, that in the safeguarding of railroad crossings by order of state or local authority the exercise of police power escapes the ordinary constitutional limitation of reasonableness of cost. This is apt to give to local boards a sense of freedom which tempts to arbitrariness and extravagance." ${ }^{95}$

The fuzzy line between extravagance and safety was for courts to determine. But an opinion like Lehigh Valley Railway Co. ruthlessly exposed just how arbitrary that line was. In the end, courts could offer only the unadorned judgment of five Justices about what was constitutionally "reasonable." This judgment could be announced, but not explained. Its authority lay precisely in its insulation from the

90. Id. at 31.

91. Id. at 41. "Mr. Justice McREYNOLDS is of opinion that the action of the Board of Public Utility Commissioners was unreasonable and arbitrary, and should be set aside. To permit the commissioners to impose a charge of $\$ 100,000$ upon the railroad . . . is to uphold what he regards as plain abuse of power." $I d$.

92. Id. at 34. "It is not for the court to cut down such expenditures, merely because more economical ways suggest themselves. The board has the discretion to fix the cost. The function of the court is to determine whether the outlay involved in the order of the board is extravagant, in the light of all the circumstances, in view of the importance of the crossing, of the danger to be avoided, of the probable permanence of the improvement and of the prospect of enlarged capacity to be required in the near future and other considerations similarly relevant." Id. at 33.

93. Id. at 34 .

94. Id. Taft remarked that " $[\mathrm{t}]$ he case before us is one which is near the line of reasonableness, but . . we think it does not go beyond the line." Id. at 35. "This is not to be construed," Taft warned, "as meaning that danger to the public will justify great expenditures, unreasonably burdening the railroad, when less expenditure can reasonably accomplish the object of the improvements and avoid the danger. If the danger is clear, reasonable care must be taken to eliminate it, and the police power may be exerted to that end. But it becomes the duty of the court, where the cost is questioned, to determine whether it is within reasonable limits." Id. at 34.

95. Id. at 34-35. 
demagogic pressure of politics. ${ }^{96}$ But when the Depression radically undermined public faith in the utility of this insulation, the temporizing constitutional jurisprudence constructed by Taft collapsed. ${ }^{97}$

96. William H. Taft, The Selection and Tenure of Judges, 7 MAINE L. REv. 203, 208-09 (1914).

It has been my official duty to look into the judiciary of each state, in my search for candidates to be appointed to federal judgeships, and I affirm without hesitation that in states where many of the elected judges in the past have had high rank, the introduction by direct primary has distinctly injured the character of the Bench for learning, courage and ability....

The result of the present tendency is seen in the disgraceful exhibitions of men campaigning for the place of state supreme judge and asking votes, on the ground that their decisions will have a particular class flavor. This is the logical development of the view that a popular election is the only basis for determining right and justice; but it is so shocking, and so out of keeping with the fixedness of moral principles which we learned at our mother's knee, and which we find recognition in the conscience of every man who has grown up under proper influence, that we ought to condemn without stint a system which can encourage or permit such demagogic methods of securing judicial position. Through the class antagonism unjustly stirred up against the courts, fiery faction is now to be introduced into the popular election of judges. Men are to be made judges not because they are impartial, but because they are advocates; not because they are judicial, but because they are partisan.

It is true that politics have played a part even when judges have been appointed. They have usually been taken from the lawyers of the prevailing party. ... This has not, however, resulted in political courts, because the control of the government has naturally changed from one party to another in the course of a generation and has normally brought to the Bench judges selected from both parties.

Id. It is notable that implicit in Taft's understanding of an apolitical bench was one that was neutral as between political parties, not one that was neutral with regard to fundamental "political" disputes about the nature and role of property.

97. Taft himself often contrasted the legitimacy he expected to be accorded to judicial decisions with the accountability that he learned (to his dismay) was demanded of politicians. Speaking to Republicans at the end of his disastrous 1912 campaign, Taft observed that "I have been used as a judge to rely upon the publicity of the judgment and opinion to justify the action taken. In executive life, however, it needs great and special effort to secure the publicity that is essential to meet the attacks of misinformed or prejudiced critics. And so it has been that, lacking in this effort, I have had to bear the burden of being thought by the people to be a very different man from that which I think I have been." Address at the Banquet of the Union League Club of New York, supra note 83, at 7. See William H. Taft, Personal Aspects of the Presidency, Saturday Evening Post, Feb. 28, 1914, at 6, 32 ("The president should devote close attention to the proper methods of getting to as wide a circle of readers as possible the facts and reasons sustaining his policies and official acts, in order that he may have the support of public opinion in working useful results. I must confess that I was lacking in attention to matters of this kind and was derelict. Both my 
Taft's jurisprudence was entirely emblematic of his era. Like Taft himself, the country was caught between the need for an effective, efficient government and repulsion at the newly expanding prerogatives of the administrative state. ${ }^{98}$ As Taft's health deteriorated during the decade of the twenties, his own judgment grew increasingly dependent upon the forceful conservative views of colleagues like Van Devanter, Butler, and Sutherland. After his 1926 heart attack, Taft would never again display the independence of mind that he had once demonstrated in his Adkins dissent. As Taft slipped, the conservative cast of the Taft Court grew more entrenched and unyielding.

If Taft's jurisprudential vision grew fatigued during his tenure as Chief Justice, his appetite for judicial reform never lagged. Long concerned with "the storm of abuse heaped upon the Federal Courts," 99

predecessor and my successor have been far wiser and more careful in this regard. Perhaps it was another result of that judicial training to which I have referred. When the judgment of the court was announced and the opinion was filed it was supposed that all parties in interest would inform themselves as to the reasons for the action taken. Newspaper men and other publishers and writers for the public know, however, that the people do not learn facts and arguments on any subjects by one announcement, and that it needs a constant effort of iteration and reiteration to send the matter home to the people whom it is wished to reach.").

Although Taft was temperamentally inclined to deemphasize the work of persuasion or explanation in ensuring public uptake of judicial decisions, when Walter Lippmann wrote Taft asking whether it would "not be possible, at the time a decision is handed down to have enough copies available so that correspondents of the interested newspapers could obtain them at once?", Letter from Walter Lippmann to WHT (Jan. 5, 1925) (Taft papers), Taft promptly replied, "I shall have great pleasure in doing what I can to help you in the matter of getting accurately the statement of what our Court decides in important cases. . . I I have felt that your editorial column, like that of many others, has suffered for lack of something like this." Letter from WHT to Walter Lippmann (Jan. 8, 1925) (Taft papers). See Letter from WHT to WVD (July 4, 1925) (Taft papers).

98. "My last eight years have been spent in going about the country, to the small towns in almost every States," Taft wrote to the Chief Judge of the New York Court of Appeals, "which convinces me that the controlling public opinion of this country is to be found in moderately-circumstanced patriotic American people who live in these towns and who are staunch in support of the Constitution and the present social order, and who can be roused by any real threat of socialism or communism. Of course they have a certain degree of inertia growing out of their confidence in things as they are, and it needs some sharp warning to arouse them to united effort, but they are there and will stay there to preserve the country. I think that politicians, and even judges, are not entirely conscious of the existence of this conservative backbone of the country, and are sometimes made timorous by the fear that we are facing a cataclysm and living on a volcano, all of which to me is ridiculous." Letter from WHT to Frank H. Hiscock, N.Y. Court of Appeals (Apr. 12, 1922).

99. William H. Taft, Criticisms of the Federal Judiciary, 29 AM. L. REv. 641, 673 (1895). 
Taft had in the nineteenth century sought to defend federal courts by justifying the substance of their jurisprudence. ${ }^{100}$ In the twentieth century, however, in the full tide of progressive efforts to subject "institutions ... to close scrutiny" and "to try experiments" to improve those institutions, Taft shifted his tack and began to propose "reforms which are in the interest of equalizing the administration of justice as far as possible between the rich and the poor." 101 In Taft's eyes, this meant making courts cheaper and more efficient. ${ }^{102}$

\section{THE CONFERENCE OF SENIOR CIRCUIT COURT JUDGES}

Taft maintained this focus throughout his presidency, ${ }^{103}$ and he redoubled his efforts after leaving office. ${ }^{104} \mathrm{He}$ urged judges to become

100. See id.

101. William H. Taft, Delays of the Law, 18 YALE L.J. 28, 30, 39 (1908). Like Brandeis, Taft paired the language of "experiments" with the metaphor of "laboratories." Judicial Council Idea Ably Presented, 9 J. Am. JudicAtURE SoC'Y 103, 104 (1925); William Howard Taft, Possible and Needed Reforms in Administration of Justice in Federal Courts 8 AM. B. Ass'N J. 601, 607 (1922).

102. “'We must make it so,' the President urged, 'that the poor man will have as nearly as possible an opportunity of litigating as the rich man, and under present conditions, ashamed as we may be of it, this is not the fact." Our Criminal Trials Disgrace, Says Taft, N.Y. TiMES, Sept. 17, 1909, at 2 [hereinafter Our Criminal Trials Disgrace]. See Kevin J. Burns, Chief Justice as Chief Executive: Taft's Judicial Statesmanship, 43 J. Sup. CT. Hist. 47, 62 (2018).

103. See, e.g., 45 Cong REC. 31 (Dec. 7, 1909) (William Howard Taft, First Annual Message to Congress); Our Criminal Trials Disgrace, supra note 102, at 2.

104. See Statement of Hon. William H. Taft, Reforms in Judicial Procedure: American Bar Association Bills, HEARINGS BEFORE THE HOUSE COMMITTEE ON THE JUDICIARY, 63 Cong., 2d Sess. 15, 17 (Feb. 27, 1914) ("There are a great many attacks on our judiciary. There are defects in the administration of justice in this country, undoubtedly ... but the trouble about most of the attacks . . . is that they are based on entirely wrong grounds. . . I am very much opposed, very much opposed indeed, to the modern suggestions with reference to reforming our courts by the recall of judges and the recall of judicial decisions .... . and therefore what I am anxious to do is to vindicate the courts by remedying the real objections to their administration of justice."); William H. Taft, The Courts and the Progressive Party, SATURDAY EvENING Post, Mar. 28, 1914, at 9, 47 ("The real defects in our present civil system are a failure to dispatch business and a failure to furnish judgment at a small cost. . . . Mr. Roosevelt has . . . seriously injured the administration of justice in this country by his unfounded criticism of the courts . ... Still there may come out of the feeling aroused by his unjust attacks and his fantastic remedy, such a popular scrutiny of the real defects in our administration of justice as to enable us to secure a real improvement and thus enable the courts, by a long, hard struggle, to regain the confidence of the public of which Mr. Roosevelt and the Progressive party have unjustly sought to deprive them."). 
"engaged in actual experiment" to improve judicial procedures. ${ }^{105}$ Categorically rejecting reforms calculated to promote "the so-called democratization of the courts," like the "[r]ecall of judges and recall of judicial decision," 106 he sought instead to identify the "grounds upon which the public have a right to complain." 107 "[W]hat I am anxious to do," he explained, "is to vindicate courts by remedying the real objections to their administration of justice." 108

The agitation with reference to the courts, the general attacks upon them, the grotesque remedies proposed of recall of judges and recall of judicial decisions, and the resort of demagogues to the unpopularity of courts as a means of promoting their own political fortunes, all impose upon us, members of the Bar and upon judges of the courts and legislatures, the duty to remove, as far as possible, grounds for just criticism of our judicial system. ${ }^{109}$

In a major speech at the Cincinnati Law School in 1914, Taft announced that the "chief grounds" for justifiable complaint "are first the delay in hearing and decision of causes; and second the excessive cost of litigation." 110 Taft proposed a six point platform for congressional reform of federal courts:

First-The antiquated system of a separation of law and equity should be abolished. ...

Second-The rules of procedure should be completely in control of the Supreme Court or a Council of Judges appointed by the

105. ReP. of the ThiRty-Ninth Annual MeEting of the Am. B. Ass'N 742 (1916).

106. William H. Taft, The Attacks on the Courts and Legal Procedure, $5 \mathrm{KY}$. L.J. 3, 4 (1916). Taft believed that these reforms "are destructive of the rights of the individual, take away the protection of the minority against the possible injustice of the majority, and are a mere recurrence to the tyranny of the Stuart Kings in their attempt to subordinate the administration of justice to their arbitrary will, except that the tyranny of the plurality of the electorate is to be substituted for the tyranny of one man. The necessary tendency of such remedies is to destroy the supremacy of the law." Id.

107. Id. at 10 .

108. See Statement of Hon. William H. Taft, Reforms in Judicial Procedure: American Bar Association Bills, HeARINGS Before the House COMMITTEE ON THE JUDICIARY, 63 Cong., 2d Sess. 17 (Feb. 27, 1914).

109. William Howard Taft, Address of the President, 39 AM. BAR Ass'N REP. 359, 384-85 (1914). "[I]n this day of hysteria and demagoguery and vicious attacks on courts, we must take away any just ground for criticism of our judicial system." William H. Taft, Legal Ethics, 2 B.U. L. REv. 161, 170 (1922). Taft's support of procedural reform in order to undermine radical critiques of judicial power was common among elite lawyers of his time. See, e.g., Walter George Smith, Civil Liberty in America, 4 A.B.A. J. 551 (1918).

110. Taft, The Attacks on the Court, supra note 106, at 10. 
Supreme Court, and they should be rendered as simple as the English rules of procedure are.

Third-The costs should be reduced to a minimum, and that as far as possible they should be imposed upon the Government rather than upon the litigants.

Fourth-Authority and duty should be conferred upon the head of the Federal judicial system, either the Chief Justice, or a council of judges appointed by him, or by the Supreme Court, to consider each year the pending Federal judicial business of the country and to distribute Federal judicial force of the country through the various districts and intermediate appellate courts, so that the existing arrears may be attacked and disposed of.

Fifth-There should be a reduction of the appeals to the Supreme Court, by cutting down to cases of constitutional construction only the review as of right, and by leaving to the discretion of that court, by writ of certiorari, the power to hear such cases from the lower courts as it deems in the public interest.

Sixth-The Federal Workmen's Compensation Act should be
passed. ${ }^{111}$

Although Taft would not live to see either rule-making authority vested in courts or the merger of law and equity, ${ }^{112}$ and although Congress would enact the Workmen's Compensation Act before he joined the Court, Taft worked hard and successfully during his time as Chief Justice to centralize the management of the federal judiciary and to alter the role of the Supreme Court.

Only three days after being confirmed as Chief Justice, Taft, in his pajamas before breakfast on a Sunday morning, scratched off some ideas about judicial reform to Attorney General Harry Daugherty. ${ }^{113}$ "I have always thought that the existing judicial force of the U.S. might

111. Id. at $14-15$.

112. Peter Graham Fish, The Politics of Federal Judicial ADMINISTRATION 22-23 (1973).

113. On the very day of his confirmation, Taft's close friend Gus Karger had telegrammed Taft to say that "Harry [Daugherty] thinks you should come to Washington soon after the fourth to take oath. Desires to put you on committee of judges to determine changes needed in federal judicial organizations." Letter from Gus Karger to WHT (June 30, 1921) (Taft papers). Two days later Taft wrote his wife, "I don't think Daugherty has very definite ideas of what he wants but his general purpose is very important and I am deeply interested in it. He made an excuse for demanding my immediate appointment because he wanted to use me in this matter. This, of itself, requires that I should conform to his purpose at however great inconvenience." Letter from WHT to Helen Herron Taft (July 2, 1921) (Taft papers). On Daugherty's concerns about congestion in federal courts, see Harry M. Daugherty, Congested Dockets in the Federal Courts Menace to Justice Says Attorney General, 13 J. CRIM. L. \& CRIMINOLOGY 609 (1923). 
be made doubly efficient in keeping down arrears," he wrote, "if it was applied at points where those arrears have a tendency to accumulate by someone made responsible by law and given authority to direct its use where needed." 114 "I would make the Chief Justice and the Senior Circuit Judges of the nine circuits upon conference with the A.G. and with his initiative a responsible machine for applying the whole judicial force of the U.S. in the inferior Courts of the U.S. to the business to be done." 115 This "would introduce a proper executive principle into the Judicial force of the country." 116 To those who objected "to giving the Chief Justice the powers involved" in such a proposal and who wished instead to lodge responsibility in the whole Supreme Court, Taft answered that it would be "a mistake. In such an executive position, one can act much more effectively and quite as wisely as nine." 117

Taft appreciated that his proposal would require the administrative capacity to determine the comparative state of dockets in different districts, and hence he concluded that

it might be well to have a conference each year . . . to consider the prospect for the year and to make all possible provision for it. This conference could also make recommendation to the Atty. General as to the need of additional Judicial force and where and of what rank, so that Congress might have the benefit of judgment formed on nothing but the need of service. ${ }^{118}$

Taft well understood that the "fears of labor and western enemies of the Federal Judiciary" would arouse the "real opposition" of those who faced the possibility of "being tried by a Judge not drawn from the vicinage and, therefore, not subject to those ameliorating local influences so dear to a man who is 'up against it'." 119 But he calculated that such resistance could be neutralized by "the strong desire for enforcement of the Volstead Law."120 "With Congress in a humor to enforce the Volstead Act, it would seem a good time to secure the right machinery to accelerate business." 121

114. Letter from WHT to Harry M. Daugherty (July 3, 1921) (Department of Justice Files, No. 144446, Section 2).

115. Id.

116. Id.

117. Id.

118. Id.

119. Id. Taft regarded the possibility of visiting judges who represented national rather than local standards as "an advantage, a good bye [sic] product of the proposal." Id.

120. Id.

121. Id. In his letter, Taft made two brief additional proposals for reform: 
Underlying Taft's push for a "proper executive principle" lay a profoundly innovative vision of the federal judiciary. As Felix Frankfurter and James Landis observed in their monumental study of federal courts,

[t] he root conceptions of our federal judicial system were independence and localism . . . . $[\mathrm{N}]$ ot only were the judges rendered independent of the President and Congress; they were rendered independent of each other. Congress created a hierarchical system of courts, not of judges. Moreover, in establishing United States courts Congress was mindful of state loyalties. . . Mobility of judicial personnel ran counter to all the traditional conceptions of American judicial organization. ${ }^{122}$

The consequence of this localism was that the federal judicial "system was without direction and without responsibility. Each judge was left to himself, guided in the administration of his business by his conscience and his temperament. The bases for informed public judgment and self-criticism were wanting, since adequate judicial statistics were unknown." ${ }^{123}$ As Taft put it, the federal judiciary was

The second change that would help much is to make all offenses in the Federal Jurisdiction except what are real felonies or infamous crimes, punishable by less than a year's imprisonment so that they may be tried on information filed by the District Attorney and shall not require the costly and expensive and delaying attention of a grand jury.

The third change would be new procedure in respect to this "Information" docket as to Jury trials. Here we come close to the Constitution. I should think that a statute might be drawn within the limitations by a provision that when the docket is called, unless a jury be demanded, it shall be deemed to be waived.

Id.

122. Felix Frankfurter \& James M. Landis, The Business of the Supreme Court of the United States-A Study in the Federal Judicial System: VI. The Conference of Senior Circuit Judges, 40 HARv. L. REV. 431, 432-33 (1927). In 1921, there did exist two precedents for the power temporarily to transfer district judges to territories other than those to which they had been appointed. The first was the Act of October 3, 1913, Pub. L. No. 18, 38 Stat. 203, which authorized the temporary transfer of judges to the Second Circuit in order to alleviate congestion in New York City, and the second was the authorization to appoint circuit judges on the Commerce Court for service on any circuit court. Pub. L. No. 218, 36 Stat. 539, 540. Frankfurter \& Landis, supra, at 44748. In December 1921, Taft was asked to certify the transfer of Nebraska Judge Woodrough to New York. Convinced that the request was suspect, Taft wrote Daugherty that "I shall be glad to welcome a time when we can sent [sic] Judges according to the reliable information as to the proportionate needs of the different parts of the country derived from a council of judges who know, rather than make it dependent on the wish of a judges to secure a vacation." Letter from WHT to Harry M. Daugherty (Dec. 4, 1921) (Taft papers).

123. Frankfurter \& Landis, supra note 122, at 434. Roscoe Pound's famous 1906 address on popular dissatisfaction with the administration of justice is 
an institution in which "each judge has paddled his own canoe and has done the best he could with his district. He has been subject to little supervision, if any." 124

Twelve days after his confirmation, Taft journeyed to Washington D.C. from Montreal, where he had been serving as an arbitrator in the Canadian government's effort to acquire the Grand Trunk Pacific Railway. He "had a long talk with the A.G." in which they discussed the "reorganization of the Courts." 125 Taft outlined legislation that could be presented to Congress, and an initial draft of his ideas was prepared for him on July 20.126

The draft proposed appointing additional district judges in each circuit and authorizing the Chief Justice to assign these judges "to any and such judicial districts ... as he may in his sound discretion deem advisable ... to the end that the services of said judges may be utilized at those places where the state of the judicial business most requires them." 227 The Chief Justice was also authorized to summon and preside over a conference of senior Circuit Judges empowered to recommend legislation to Congress "adapted to cheapen and expedite litigation in the United States Courts" and "[t]o make, modify, amend or repeal rules of practice and procedure in all Districts Courts of the United States to the end that pleadings and trials in said courts shall be shortened and simplified, and all causes, civil and criminal, therein,

conventionally credited with having first "roused the attention of the profession to the relation between our anarchic judicial organization and popular dissatisfaction with the administration of justice." Id. at 437. See Roscoe Pound, The Causes of Popular Dissatisfaction with the Administration of Justice, 29 AM. REP. AM. B. Ass'N 395, 395 (1906). Pound had complained of the division of courts into "rigid districts . . . so that business may be congested in one court while judges in another are idle." Id. at 412. Pound's paper had inspired the creation of an ABA committee, whose 1909 report, according to Frankfurter and Landis, gave "the lead to all contemporary movements for judicial reform. To its principles we owe the momentum for a unified judiciary and a judicial council." Frankfurter \& Landis, supra note 122, at 437. Frankfurter and Landis observed that "[w]ith all the weight of his authority and experience, exPresident Taft directed this general movement for judicial reform into federal channels." Id. at 441.

124. William H. Taft, Adequate Machinery for Judicial Business, 7 A.B.A. J. 453, 454 (1921).

125. Letter from WHT to Helen Herron Taft (July 12, 1921) (Taft papers). Taft wrote his brother, "I suppose I shall take the oath on Monday in the A.G.'s office. Then the A.G. wants me to act as Chairman of a Committee to . . . recommend some means of meeting arrears in the trial courts of the U.S. growing out of this new liquor Amendment and the Volstead Law." Letter from WHT to Horace D. Taft (July 8, 1921) (Taft papers).

126. Letter from M.C. Herron to WHT (July 20, 1921) (Taft papers).

127. Id. 
shall be proceeded with and terminated as cheaply and expeditiously as is in any way possible."128

It is apparent that Taft, with the eye of a former Chief Executive, conceptualized the Article III judiciary as a unified branch of national government, oriented to the achievement of a distinct function. As Taft had affirmed in his 1914 American Bar Association (ABA) presidential address, the problem of disposing of litigation must be approached "in the same way that the head of a great industrial establishment approaches the question of the manufacture of the amount that he will need, to meet the demand for the goods which he makes. ... [T] The time has come to introduce into the dispatch of judicial work something of the executive method that great expansion has forced in other fields of human activity." 129

Although in the end Taft would not get exactly the bill that he wanted, ${ }^{130}$ the Act of September 14, $1922^{131}$ was nevertheless a major triumph. It marked, as Frankfurter and Landis rightly observed, "the beginning of a new chapter in the administration of federal courts," a chapter that could not have occurred without "the powerful support of the new Chief Justice." 132 The Act authorized the Chief Justice to summon and preside over a Conference of Senior Circuit Judges. ${ }^{133}$ It allowed the Chief Justice to transfer

128. Id. The draft act also provided that "the prosecution of all misdemeanors in the United States Courts shall be on information." It also required that each criminal defendant be presented with "two printed forms, one demanding and the other waiving a jury." The Act abolished "all terms of Court in District Courts" and provided that they "shall be held to be constantly in session." It is in this context that Brandeis wrote Taft that he was "delighted to hear that you have undertaken the task of making more efficient the administration of our law. It is by such intelligent appreciation of existing defects and determined effort to devise remedies that respect for law may be promoted." Letter from LDB to WHT (July 19, 1921) (Taft papers).

129. Taft, Address of the President, supra note 109, at 383-84.

130. See, e.g., Letter from WHT to Arthur C. Denison, Judge (Apr. 16, 1922) (Taft papers) (noting that the bill "added a limitation that the senior circuit judge of the circuit needing the aid shall certify the need to me, and that the circuit judge of the circuit from which the district judge is to be taken shall certify that it will not interfere with business in his circuit. I do not object to this limitation if it does not result in leaving it largely to the choice of the judge to be assigned whether he shall go or not").

131. Pub. L. No. 67-298, 42 Stat. 837 (1922).

132. Frankfurter \& Landis, supra note 122, at 455-56. See C.S. Potts, Unification of the Judiciary; A Record of Progress, 2 TeX. L. REv. 445, 452-53 (1924). The story of the Act is well told in FISH, supra note 112, at 24-39.

133. The Act stated that "[i]t shall be the duty of every judge thus summoned to attend said conference, and to remain throughout its proceedings, unless excused by the Chief Justice, and to advise as to the needs of his circuit and as to any matters 
district judges to where they were most needed so long as there was a certificate of need from the senior circuit judge of the receiving district and a certificate of dispensability from the senior circuit judge of the releasing circuit. The Conference was charged with making "a comprehensive survey of the condition of business in the courts of the United States" and preparing "plans for assignment and transfer of judges," as well submitting "suggestions to the various courts as may seem in the interest in the interest of uniformity and expedition of business." 134 The Act also created twenty-four new district court positions, increasing the number of federal district judgeships by about $20 \% .{ }^{135}$

in respect of which the administration of justice in the courts of the United States may be improved." Pub. L. No. 67-298, 42 Stat. 837 (1922).

134. The Conference was not given the power to "[t]o make, modify, amend or repeal rules of practice and procedure in all Districts Courts of the United States," as Taft had wished. But Taft's vision has in the end proved highly influential. Currently the Judicial Conference of the United States possesses authority to study "the operation and effect of the general rules of practice and procedure now or hereafter in use as prescribed by the Supreme Court for the other courts of the United States pursuant to law. Such changes in and additions to those rules as the Conference may deem desirable to promote simplicity in procedure, fairness in administration, the just determination of litigation, and the elimination of unjustifiable expense and delay shall be recommended by the Conference from time to time to the Supreme Court for its consideration and adoption, modification or rejection, in accordance with law." 28 U.S.C. $\$ 331$ (2018).

135. Letter from WHT to Charles D. Hilles (Feb. 5, 1923) (Taft papers) ("The passage of the bill to increase the Federal judiciary is one of the most important acts in the history of the judiciary, not only because it adds about 20 per cent to the number of Judges of the courts of first instance, but also because it creates a body of the senior circuit judges of the country from the nine circuits, presided over by the Chief Justice, which is empowered by sending judges from one district and one circuit to another, temporarily to mass the force of the judiciary where the arrears are greatest."); Judith Resnik, Building the Federal Judiciary (Literally and Legally): The Monuments of Chief Justices Taft, Warren, and Rehnquist, 87 IND. L.J. 823, 863 (2012).

Taft had pushed for the appointment of eighteen new District Judges, but he wanted them designated as "district judges at large" so that they could be freely moved between districts. Letter from WHT to Harry M. Daugherty (Aug. 8, 1921) (Taft papers). Instead the judges were appointed to permanent districts. The extra judges were justified by the judicial commission appointed by Daugherty (consisting of judges John E. Sater, W.I. Grubb, John C. Pollock, and district attorneys William Hayward and Charles F. Clyne) as needed to combat congestion due "not only to our country's normal growth in population and business, but also to the increase of business caused by the war, the subsequent depression and readjustment, the increased activities of the Federal Government as evidenced by statutes enacted under the power of Congress to regulate interstate commerce, the recent internal revenue laws including the income tax and excess profits laws, and especially the national prohibition act." AdDitional District Judges for Certain Districts, etC., H.R. 
Taft lobbied hard for the Act and received the lion's share of the credit for its enactment. ${ }^{136}$ It realized the essence of Taft's vision, which he had expressed in an August address to the Judicial Section of the ABA, as establishing in Article III courts an "executive principle of using all the judicial force economically and at the point where most needed" by securing "effective teamwork" and an "organized effort to get rid of business." 137 In

REP. No. 67-482, app. D, at 18 (Nov. 17, 1921). The prediction of the commission was that congestion caused by Prohibition would decline, so that positions for new judgeships in the proposed 1922 act would not be replaceable without explicit congressional action. See, e.g., Letter from Harry M. Daugherty to WHT (July 22, 1921) (Taft papers); see also Letter from Harry M. Daugherty to WHT (Aug. 22, 1921) (Taft papers).

In the end, Taft yielded to the sentiment that judges be appointed to fixed and assigned districts. "If we can not get the Judges one way, we must have them the other." Letter from WHT to Ralph Peters (Nov. 13, 1921). Democrats opposed the vast increase in the federal judiciary, suspecting it of arising from partisan Republican efforts to pack the courts. Letter from WHT to Francis E. Baker, Judge, U.S. 7th Cir. (Jan. 22, 1922) (Taft papers). See Henry P. Chandler, Some Major Advances in the Federal Judicial System 1922-1947, 31 F.R.D. 307, 329 (1962).

136. Taft was recognized as the "author" of the "historical" Act, which realized "the best ideals of judicial organization." A New Era Opens, 6 J. AM. JudiCATURE SOC'Y 67, 67 (Oct. 1922). "It is not too early now for congratulations over the progress made and the bright prospects, for before long the providential circumstance of Chief Justice Taft's appointment, in view of his broad understanding of the needs of the courts, will be generally recognized. Taking advantage of the need for more judges, which might otherwise have led merely to greater complexity and waste, the Chief Justice has obtained legislation which creates a right foundation for procedural reform." Id. "It was singularly fortunate, then, that when the federal trial courts were cracking under undue strain Mr. Taft should have been made administrative head of the entire system. There were, of course, others who appreciated the opportunity for notable legislative advance in respect to the federal courts, but were it not for the great esteem felt for the Chief Justice, and for his tact and persistence, something far inferior to the actual law would have resulted." New Law Unifies Federal Judiciary, 6 J. Am. Judicature SoC'y 69, 69 (Oct. 1922). "[I]f any way out of the bogs and quicksands can be found it will be found under the powers established by the new act and through the administration of the Chief Justice, to whose intelligence and unselfish effort its passage is largely due." Id. at 70 . "Influenced largely by Chief Justice Taft's recommendations, Congress has provided for a considerable expansion of the Federal Judiciary. . . . Mr. Taft has been one of the most earnest advocates of a simplification and speeding up of justice. . . . He will have the public's support in his experiment with the Federal judiciary." More Federal Judges, N.Y. TRIB., Apr. 10, 1922, at 10.

137. Taft, Adequate Machinery for Judicial Business, supra note 124, at 454. For a blow-by-blow of the legislative history and Taft's involvement, see Chandler, supra note 135, at 324. A glimpse of Taft's version of the negotiations involved in the passage of the bill may be found in a December 1921 address he gave to the Chicago Bar Association. See generally William Howard Taft, Three Needed Steps of 
essence, the Act implied "a functional unification of the United States judiciary." 138

Just as the executive branch has always been seen as an integrated whole, directed by the President, the Act for the first time conceptualized federal judges also as integrated into a single branch of the federal government designed to attain specific functional objectives. ${ }^{139}$ Previously, as Felix Frankfurter has observed, "federal judges throughout the country were entirely autonomous, little independent sovereigns. Every judge had his own little principality. He was the boss within his district, and his district was his only concern." 140 The Act was based on the entirely different premise that "the whole judicial force" be "organized as a unit, with authority to send expeditions to spots needing aid." ${ }^{141}$

This premise may seem obvious to us today, but in 1922 it provoked great resistance. No less a judge than Henry D. Clayton (after whom the Clayton Act was named) attacked the Act as manifesting "a dictatorial power over the courts unrecognized in our

Progress, 8 A.B.A. J. 34 (1922). At that time, Taft stressed that the "most important"
feature of the bill (which then consisted in both a Senate and a House version) was its
provision "for annual . . meetings at the call of the Chief Justice, of the senior circuit
judges of the nine circuits . . . to take up the question from year to year of the arrears
of business, and after conference to agree and recommend a plan, thereafter to be
carried out in the discretion of those in authority, for the massing of the extra judicial
force at strategic points, and thus overcoming the enemy known as 'arrears in
business." Id. at 34 . The premise of the bill, Taft argued, was that "[j]udges should
be independent in their judgments, but they should be subject to some executive
direction as to the use of their services, and somebody should be made responsible for
the whole business of the United States. This council of the Chief Justice and the
senior circuit judges of the nine circuits is as well adapted to do this work as anybody
that can be suggested." Id. at 35 . As Taft later observed, "[t]he Conference means
much for producing solidarity and efficiency in the organization of the Federal
Judiciary. I got the provision which made it possible into an Act of Congress in 1922,
and it is therefore my child." Letter from WHT to Mary Patten (Oct. 10, 1927) (Taft
papers).

138. See Rally Support for Daugherty Bill: Bar of Entire Country Asked to Lend Assistance in Campaign for Effective Organization of United States Judiciary, 5 J. AM. JUdiCATURE SOC'Y 120, 120 (1921).

139. See New Law Unifies Federal Judiciary, supra note 136, at 69 (stating that "[t]he judicial system of the United States is unified. [The Act of September 14, 1922] creates a unified system of trial and appellate courts with statistical records, a judicial council, a chief judicial superintendent and the transfer and assignment of judges. It embodies the principle of unification in its entirety").

140. Felix Frankfurter, Felix Frankfurter On THE SuPREMe COURT 487 88 (Philip B. Kurland ed., 1970).

141. The First Conference, 9 A.B.A. J. 7, 7 (1923). 
jurisprudence." ${ }^{142}$ Clayton objected to "[t]he war idea of mobilizing judges under a supreme commander as soldiers are massed and ordered." ${ }^{143} \mathrm{He}$ argued that "[j] udges are not soldiers but servants, and the people only are the masters whom they serve." 144

142. Henry D. Clayton, Popularizing Administration of Justice, 8 A.B.A. J 43, 45-46 (1922). On the floor of the Senate Tennessee Senator Shields argued that "I believe there are provisions giving the Chief Justice power over the lower courts which was never contemplated by our system of government . . . . I consider it a very serious assault upon the independence and dignity of the several judges of the district courts of the United States." 67 CONG. REC. 11669 (1922) (statement of Sen. Shields).

143. Clayton, supra note 142, at 46.

144. Id. The Act also provoked great resistance on the grounds of localism, because it was said to create "a flying squadron of judges, as introducing a new practice and a new principle in the judiciary of the United States." 62 CONG. REC. 11671 (1921) (statement of Sen. Shields). See The Proposed "Alien" Judges, ST. Louis Post DisPatch, Apr. 7, 1922, at 22 ("[I]t is un-American and contrary to our traditions to be subjected to 'alien' Judges; . . . the right of trial by a jury of the vicinage includes as well a trial before a Judge having some contact with the community in which he serves; . . . to send in Judges from distant parts smacks of Jeffreysism."). As Taft wrote his brother:

The additional judges' bill is on. I am very much interested in it. And so is Wayne B. Wheeler [general counsel] of the Anti-Saloon League. [Senator] Shields of Tennessee sees in all this as possibly corrupting-did I say possibly? I should have said certainly corrupting relation because Wheeler and his myrmidons, and me in sending drying judges into wet territory-for the bill contains a provision by which we have a council of senior circuit judges and myself meeting once a year to consult as to the most feasible way of massing our judicial force at the points where the arrears are greatest. I consider this essential to making the addition of 25 judges contemplated by the Bill really useful. Wheeler is arraigned for wishing for machinery to enforce the law. . . . You will note today and perhaps during the week some roaring by Borah, Norris, Lafollette and perhaps Johnson, as well as some Democrats against me as seeking power instead of attending to the high and lofty duties of my great office, and as jointly acting with wicked Wheeler in seeking to secure enforcement of the law. The Democrats are going to line up against the bill I fear . . . and this on the far fetched idea that if the antilynching bill were to pass Congress and our Court, it might lead to assignment of Northern Judges to try southern lynchers. As nobody but the local District Judge can assign visiting judges to particular cases, of course, there is nothing in all this but it may be a 'good enough Morgan' to beat the Bill though I hope the Republicans will rally enough to sustain this feature of the Bill. Their interest in the additional patronage will lead them to press the bill, but I am afraid of a compromise to get it through by sacrifice of the best and indispensable feature of the bill. I always have Borah, Norris, Lafollette and Johnson against anything I wish-for my sins I suppose. It is partly personal and partly because we never like the same things. 
To protests like these, Taft responded with the brutal and implacable language of managerial rationality. Although Taft conceded that "in the judicial work a judge does on the bench, he must be independent," he nevertheless insisted that "in the disposition of his time and the cases he is to hear, he should be subject to a judicial council that makes him a cog in the machine and makes him work with all the others to dispose of the business which courts are organized to do." 145 The premise that judges are "organized" to accomplish a collective function rendered the federal judiciary structurally parallel to an executive agency. ${ }^{146}$

If judges are "cogs in a machine," there must exist some intelligence that directs the machine. Organizations require guidance, and the functional unification of the judiciary thus implied the

Letter from WHT to Horace D. Taft (Apr. 3, 1922) (Taft papers). See Letter from WHT to Elihu Root (Apr. 5, 1922) (Taft papers).

After the debate on the bill in the Senate, Taft wrote his brother, "Tom Watson of Georgia was in a state of mad fury over the thought of sending a N.Y. Judge down to Georgia to try a patriot for lynching. The shades of Jeffreys . . . rose before him and he shuddered to think what a little "thoroughness" from the North would do to Georgia. It might jail some of their best citizens. Wayne Wheeler of the Anti-Saloon League was working for the bill and helped it. This time he was for law enforcement and of course that was a high crime. The cowards and trimmers are in a bad way between the Anti-Saloon league and the demagogic vote against the Courts." Letter from WHT to Horace D. Taft (Apr. 9, 1922) (Taft papers).

The values of localism could apply not only against Northerners going South, but also against Southerners coming North. In 1929, for example, Congressman Fiorello H. La Guardia wrote an outraged letter to Taft because a visiting judge from Arkansas named John Ellis Martineau had berated and humiliated a jury for acquitting a "colored man." "Apparently some Judges cannot understand a white jury acquitting a colored defendant." "It is manifestly unfair to assign Judges to New York who do not understand local conditions, who are reared in the narrow atmosphere of provincial backwoods and who have strong feelings toward certain races and creeds." Letter from Fiorello H. La Guardia to WHT (July 27, 1929) (Taft papers).

145. Letter from WHT to Ewing Cockrell, Judge (May 5, 1927) (Taft papers).

146. See, e.g., Power and Responsibility, 8 A.B.A. J. 625, 625 (1922) ("The principle which the Chief Justice urges in respect to judicial machinery is not one which applies to that branch of governmental administration alone. He is simply attempting to have applied ... the approved ideas which are . . the basis of sound movements of administrative reform throughout the country. Scientific attempts to improve governmental machinery within the last two decades may be generalized as efforts to make the power of officials equal to the responsibility with which they are charged ... That is the approved formula of efficiency - as far as machinery goes."); Judicial Efficiency Experts, 12 A.B.A. J. 32 (1926). In contrast to wild progressive efforts at reform, the Act of September 14 was said to be "based on sound and practical principles and is not merely an illustration of a too common mania for solving problems by the creation of new and multiplied agencies." The Judicial Council, 11 A.B.A. J. 508, 508 (1925). 
"executive management" of "a head charged with the responsibility of the use of the judicial force at places and under conditions where the judicial force is needed." ${ }^{147}$ The Act transformed the federal judiciary from an "entirely headless and decentralized" institution, ${ }^{148}$ into one capable of "executive supervision." 149

Taft defended this transformation as a matter of "introducing into the administration of justice the ordinary business principles in successful executive work." 150 This same principle of executive supervision had also been central to Taft's conception of the Presidency, which he regarded as responsible for "administrative control" of the executive branch. ${ }^{151}$ In Taft's mind, the Chief Justice, using the Conference of Senior Circuit Judges as a kind of cabinet, was responsible for the management of the judicial branch in the same way that the President was responsible for the management of the executive branch. ${ }^{152}$

147. Taft, The Attacks on the Court, supra note 106, at 16-17. "A judicial force of Judges ought to be under the executive direction of somebody," Taft said, "so that the number of Judges needed to meet the arrears of business at a particular place should be under the control of one who knows what the need is." Letter from WHT to Charles F. Ruggles (Nov. 4, 1924) (Taft papers).

148. See Potts, supra note 132, at 445.

149. Taft, The Courts and the Progressive Party, supra note 104, at 47. "What is needed," wrote Taft, "is a General Director who shall be able to mass judicial force temporarily at places where the arrears are greatest and thus use what is available to do the whole judicial work. There ought to be more unity in the application of Judges at the strategic points where application is needed." Letter from WHT to Angus Wilton McLean (Dec. 1, 1924) (Taft papers).

150. See Taft, The Attacks on the Court, supra note 106, at 16. "One of the reasons why in this country we have got into such great delays in the administration of justice is that Judges have considered themselves independent in the matter of responsibility for the disposition of business, and the method of hearing cases under the old system has become a kind of 'go as you please' method, which does not make for reasonable dispatch in the finishing of cases. Someone, therefore, ought to be made the chief of the body of Judges who cover a certain territory and have the power to assign the business, so that each Judge shall be bound to follow that assignment. There is not the slightest reason why the same strategy ... should not be secured as you find in large business corporations." Letter from WHT to Harry A. Hollzer (Feb. 14, 1928) (Taft papers).

151. Myers v. United States, 272 U.S. 52, 122 (1926).

152. See supra note 144 and accompanying text. That is why Taft all along considered the judicial conference "the kernel of the whole progress intended by the bill." Taft, Adequate Machinery for Judicial Business, supra note 124, at 454 . Frankfurter and Landis shared this view:

Hundreds of judges holding court in as many or more districts scattered over a continent must be subjected to oversight and responsibility as parts of an articulated system of courts. The judiciary, like other political institutions, 
Taft thus transfigured the role of the Chief Justice from the administrator of the Supreme Court into something more comparable to the administrator of the federal judiciary. It is because of Taft, and because of the vision that gave rise to the Act of September 14, 1922, that we today so casually refer to the Chief Justice "[a]s the head of the federal judicial branch." 153 Today the Chief Justice is required by law to "submit to Congress an annual report of the proceedings of the Judicial Conference and its recommendations for legislation," 154 and Chief Justices are often expected to deliver an annual "State of the Judiciary Address." 155

Although the Act did not invest the Conference with a broad mandate to engage in judicial reform as Taft had originally desired, ${ }^{156}$ Taft considered "the language of the act" to be "wide" enough to permit him "to make" the Conference into "an instrument for the consideration of many defects in one system and for the recommendation of remedies." 157 During the course of the decade, Taft deftly and effectively forged the Conference into the organized voice of the federal judiciary, diagnosing problems and offering solutions in the form of both best practices and proposed legislation.

The Conference held its first meeting barely three months after the passage of the Act and promptly set up committees on such subjects as improving the bankruptcy and equity rules, amending appellate procedure, recommending to district judges changes in local procedures designed to expedite the disposition of pending cases and ridding the docket of dead litigation, and so on. ${ }^{158} \mathrm{In}$ its second meeting in 1923, the Conference recommended that district judges not allow continuances by agreement of counsel ("except for good cause shown by affidavits"), that the voir dire of potential jurors be conducted by

must be directed .... An executive committee of the judges, with the Chief Justice of the United States at its head, is a fit and potent instrument for the task.

Frankfurter \& Landis, supra note 122, at 456.

153. Kristin Linsley Myles et al., Hail to the Chief, 48 TenN. B.J. 12, 12 (2012).

154. See 28 U.S.C. $\$ 331$ (2018).

155. See, e.g., JoHn G. Roberts, 2006 YEAR-End RePort ON THE FEDERAL JudiCIARY, 39 THE THIRD BRANCH 4 (No. 1) (2007) (delivering "[his] second annual report on the judiciary"); Fred P. Graham, Burger to Speak on "State of Judiciary", N.Y. Times, Aug. 7, 1970, at 29; Warren E. Burger, The State of the Judiciary Address: The Time Is Now for the Intercircuit Panel, 71 A.B.A. J. 86, 86 (1985).

156. Compare supra note 128 and accompanying text, with supra note 134 and accompanying text.

157. Letter from WHT to Horace D. Taft (Dec. 26, 1922) (Taft papers).

158. See Potts, supra note 132, at 459. 
judges rather than by counsel, and that legislation be passed simplifying procedure and unifying causes of action. ${ }^{159}$ It requested that Congress authorize five additional judgeships. ${ }^{160}$ Three months later, in his annual message to Congress, President Calvin Coolidge explicitly endorsed this request of what he called the "Judicial Council." "161

Beginning in 1924, the recommendations of the Conference were officially reproduced in the reports of the Attorney General. Over the remainder of the decade, these recommendations included advocating that the "the prohibition unit" be removed from the Treasury Department and "be bodily transferred to the Department of Justice"; ${ }^{162}$ proposing detailed new bankruptcy rules to the Supreme

159. Id. at 461.

160. See id. at 463. The Conference also reported:

That the chairman of the committee [on Recommendations to District Judges of Changes in Local Procedure to Expedite Disposition of Pending Cases and to Rid Dockets of Dead Litigation] be authorized to prepare a bill, for the approval of the council, upon the subject matter of the following recommendations made by the committee:

In prohibition and other misdemeanor cases, authorize the United States commissioners, in all cases in which the defendants do not file written demands for jury trial, to take and file written pleas of guilty and to hear the evidence on pleas of not guilty and to file in court their reports of the cases and their recommendations of what judgment should be entered.

That the conference now express [sic] its opinion that such a bill as is referred to in the preceding paragraph would be expedient, provided the machinery proposed is within constitutional limits.

$I d$. at 461. The Conference echoed Taft's July 3, 1921 letter to Daugherty. See supra note 121 and accompanying text. Taft wrote his brother, "The most important suggestions are rules to prevent delay in impaneling a jury which has been a stench in the state courts, and for getting rid of misdemeanor cases in Federal courts when a jury is waived." Letter from WHT to Horace D. Taft (Sept. 30, 1923) (Taft papers). Something like Taft's views on this matter was later enacted into law in Act of October 9, 1940. See Act of Oct. 9, 1940, 54 Stat. 104; see also Act of Dec. 16, 1930, 46 Stat. 1029.

161. See Calvin Coolidge, Annual Message to Joint Session of Senate and House of Representatives, 65 CONG. REC. 98 (Dec. 6, 1923).

162. See Addenda: Recommendations of the Judicial Conference, ANNUAL REPORT OF THE ATtORNEY GENERAL OF THE UNITED STATES FOR THE FISCAL YEAR 1924 iii (1924). Despite the vigorous opposition of the influential Wayne Wheeler, general counsel of the Anti-Saloon League, this recommendation was ultimately accepted on May 27, 1930. See Wayne B. Wheeler, In re Proposal to Transfer the Prohibition Enforcement Unit to the Department of Justice, 98 CENT. L.J. 9, 9 (1925); The Prohibition Reorganization Act of 1930, 46 Stat. 427 (1930). See Letter from WHT to Horace D. Taft (Oct. 2, 1924) (Taft papers); Letter from Wayne B. Wheeler to WHT (Nov. 26, 1924) (Taft papers); Letter from WHT Wayne B. Wheeler (Nov. 27, 1924) (Taft papers). 
Court; ${ }^{163}$ promulgating precise "suggestions" to district courts about how to eliminate deadwood from their dockets and expedite their proceedings; ${ }^{164}$ recommending annual expenditures on judicial libraries and a plan for allocating these funds; ${ }^{165}$ cautioning against the abuse of conspiracy charges "for converting a joint misdemeanor into a felony"; ${ }^{166}$ urging district judges to be careful in granting bail after

163. Letter from WHT to the U.S. Supreme Court (Nov. 25, 1924) (Taft papers) (transmitting detailed proposed amendments to the bankruptcy rules Recommendations for Amendments to Bankruptcy Rules, Adopted by the Judicial Conference of Senior Circuit Judges (Taft papers)); Recommendations Adopted by the Judicial Conference of Senior Circuit Judges, 98 CENT. L.J. 13, 13-14 (1925). These recommendations were promulgated on April 13, 1925. See General Orders in Bankruptcy, 267 U.S. 613, 613-16 (1925). For the background of the rules, see Improving Bankruptcy Practice Conditions, 10 A.B.A. J. 155 (1924).

164. See Letter from WHT to the Dist. and Cir. Judges of the U.S. (Nov. 29, 1924) (Taft papers) (enclosing Suggestions of the Judicial Conference to United States District Judges for the dispatch of business). In 1927, the Conference reported that "[t]his suggestion has been adopted in a great many districts and has resulted in the removal from the docket of many dead cases, which until their dismissal or removal gave the appearance of a congestion of business which the conditions did not justify and were misleading as to the necessity for additional judges or courts." ANNUAL REPORT OF THE ATTORNEY GENERAL OF THE UNITED STATES FOR THE FiscAl YEAR 1927 4-5 (1927). The Conference thought it "wise, therefore, to renew and emphasize the suggestion of 1924" that courts dismiss inactive cases. Id. at 5.

165. See Addenda: Recommendations of the Judicial Conference, supra note 162; Expenditures of Appropriations for Law Books, ANNUAL REPORT OF THE AtTORNEy GENERAL OF THE United STATES FOR THE FISCAL YEAR 1925 6-8 (1925). The Conference's recommendations in this regard were evidently successful; Congress appropriated special funds for court libraries "to be expended under the direction of the Attorney General but subject to the approval of the conference of senior circuit judges established by section 2 of the Act of September 14, 1922." Pub. L. No. 68-631, 43 Stat. 1333 (1925). "The result is that for the first time in many years the district judges find that they are fairly well supplied with their necessary tools, and the circuit courts of appeals have reasonably satisfactory libraries .... We have no doubt that the efficiency of the Courts has been substantially increased by the aid which this Congressional appropriation has given." ANNUAL REPORT OF THE AtTORNEY GENERAL OF THE UNITED STATES FOR THE FISCAL YEAR 19269 (1926).

166. ANNUAL REPORT OF THE ATTORNEY GENERAL OF THE UNITED STATES FOR THE FisCAL YEAR 19255 (1925). See Conspiracy Indictments, N.Y. Times, June 12, 1925, at 18; Wheeler Upholds Use of Conspiracy Charge, BALT. Sun, June 12, 1925, at 2. Brandeis particularly approved of this recommendation. See Letter from LBD to WHT (July 10, 1925) (Taft papers) ("The recommendation concerning conspiracy should bring an end to an unworthy and dangerous practice."). No immediate law reform followed the Conference's recommendation. But see Amendment to Section 37 of the Penal Code, Committee on the Judiciary, Senate Report No. 44, 69th ConG. 1st SESS. (January 16, 1926) (proposing a bill enacting the recommendation of the Conference). In 1948, Congress amended the penal code substantially to embody the Conference's recommendation. See Pub. L. 80-772, 62 Stat. 701 (1948). 
conviction "to discourage review sought, not with hope of new trial, but on frivolous grounds merely for delay"; 167 advising district courts that "[c]riminal cases should be forced to trial within what the court deems a reasonable time"; 168 advising circuit courts of appeals to "adopt the plan now followed in the Supreme Court, of advancing, for the earliest hearing possible, all writs of error and habeas corpus cases involving the prosecution of crime, and, so far as the statutes permit, giving them preference over every other class of hearings"; ${ }^{169}$ suggesting that circuit courts of appeals stay their mandates for not longer than 30 days to provide time for the filing of writs of

167. ANNUAL REPORT OF THE ATTORNEY GENERAL OF THE UNITED STATES FOR THE FISCAL YEAR 19256 (1925). The report of the conference reads, "The right to bail after conviction by a court or a judge of first instance or an intermediate court or a judge thereof is not a matter of constitutional right." Id. See Letter from WHT to Robert A. Taft (June 7, 1925) (Taft papers) ("Next week if the heat does not melt them, I expect to have here the Senior Circuit Judges of the Country . . . . [W] e may make some further recommendations as to the District Judges with reference to the granting of bail to people convicted pending appeal. There has been a good deal of misconception about what the rights of a man are who has been convicted by a jury and sentenced. The presumption is he is guilty under those circumstances, but I don't think he ought to be allowed to get out on bail and then delay his appeal, because time always makes for the guilty defendant."). Taft later wrote Brandeis about this recommendation, "I thought it was well, too, that we should advise the District Judges that they were not helpless in responding to a demand for bail after conviction, when the appellate proceedings were evidently taken for delay. There is an opinion by Gray, in the Hudson case I think it is, on this subject, in which I think he goes too far, and which, should we get an opportunity, we can reasonably qualify so as not to prevent District Judges from discrimination in cases of this kind." Letter from WHT to LBD (July 6, 1925) (Taft papers).

168. ANNUAL REPORT OF THE ATTORNEY GENERAL OF THE UNITED STATES FOR THE FisCal Year 19267 (1926). See L.A. Mfg. Co. v. James, 272 U.S. 701, 708 (1927) (discussing the tension between unreasonable delay in trying patent cases and the "[a]rguments based on humanity and necessity for the preservation of public order [which] require that criminal cases should be given a reasonable preference," in light of "an emergency, due to a lack of judges in some districts, which we can not ignore").

169. ANNUAL REPORT OF THE ATTORNEY GENERAL OF THE UNITED STATES FOR THE FISCAL YEAR 19276 (1927). Brandeis had written Taft on the morning of the first day of the 1927 Conference that "I venture to suggest that you urge upon its members to follow our practice in advancing criminal cases." Letter from LBD to WHT (Sept. $27,1927)$ (Taft papers). Taft responded, "I have your note of to-day, and I shall bring up to the Conference the matter to which you refer. I think it is a good suggestion, though I am inclined to think that it is probably complied with already by most of the Courts of Appeal." Letter from WHT to LBD (Sept. 27, 1927) (Taft papers). Taft was as good as his word, and the Conference was apparently quite agreeable. 
certiorari; ${ }^{170}$ and recommending that Congress provide a law clerk to each circuit judge. ${ }^{171}$

And then, of course, there were reiterated recommendations for the creation of new judgeships to meet congestion in specific courts that the Conference had come to believe were understaffed. It became quickly clear, as Taft wrote to Attorney General John G. Sargent, that "while the transfer of Judges from District to District and from Circuit to Circuit is of the utmost benefit, it can not make up for the lack of Judges in Districts where the congestion is hopeless." 172 The Conference accordingly recommended the creation new federal

170. ANNUAL REPORT OF THE ATTORNEY GENERAL OF THE UNITED STATES FOR THE FISCAL YEAR 19276 (1927). Taft reported to Van Devanter that "I would like to have the Circuit Courts of Appeal know that we are glad to have their cooperation in speeding cases through our Court, and I would not like to give the impression that we don't appreciate their purpose in adopting such a rule. Of course [Judge Walter H.] Sanborn went right back from the Conference and had the rule adopted in his court, and I suppose that has been done pretty well through the country." Letter from WHT to WVD (Oct. 31, 1927) (Taft papers).

171. ANNUAL REPORT OF THE ATTORNEY GENERAL OF THE UNITED STATES FOR THE FISCAL YEAR 19276 (1927). Citing the recommendation of the Conference, Congress granted this request in 1930. See Pub. L. 71-373, 46 Stat. 774 (1930); S. REP. No. 71-830, at 1 (1930); H.R. REP. No. 71-30, at 1 (1929).

172. Letter from WHT to John G. Sargent, U.S. Attorney Gen. (Apr. 17, 1925) (Taft papers). Taft also noted to the Attorney General in this correspondence that Senior Circuit Judge Woods "reports to me that the present District Attorney named Tolbert, in the Western District of South Carolina, is not competent to discharge the duties of District Attorney. I suggest that an agent might be sent to investigate this matter." Id. As an afterthought, Taft added, "I hope you will not think I am trying to intrude in matters that are solely within your jurisdiction; but I am very anxious to make the conference of Circuit Judges as useful as I can and to justify its creation. We need team work to facilitate the agencies available for effective administration of federal justice." Id. Sargent replied, "I assure you that I not only do not think you are intruding in matter in my jurisdiction, but I am very grateful for the assistance received.” Letter from John G. Sargent to WHT (Apr. 20, 1925) (Taft papers). 


\section{judgeships each year after 1923. ${ }^{173}$ These recommendations proved spectacularly persuasive and successful. ${ }^{174}$}

173. In 1923, the Conference recommended that two new judgeships be created for the S.D.N.Y., one for the N.D. Ga., and two new circuit judges for the Eighth Circuit. Potts, supra note 132, at 463. These requests were endorsed by President Coolidge. See Coolidge, supra note 161.

In 1924, the Conference reiterated these requests, adding a recommendation that new district judgeships be provided for the W.D.N.Y. and the D. Md. See ANNUAL

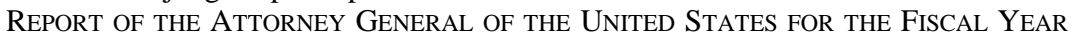
1924 iii (1924).

In 1925, the Attorney General concurred in all of the Conference's remaining outstanding requests, as well as in the Conference's additional requests for a third judge for the S.D.N.Y., a judge for D. Conn., and a judge for the Second Circuit. The Attorney General also concurred in the Conference's recommendation that the position of a judge appointed in the E.D. Pa. under the Act of September 14, 1922, which had expired upon the death of the occupant, be reauthorized. See ANNUAL REPORT OF THE ATtORNEY GENERAL OF THE United States FOR THE FisCAL YeAR 19255 (1925). The Conference stated that it preferred that the additional district judge for Georgia be placed in a newly established "third district in that State." Id. In 1926, the Conference requested judgeships for the E.D.N.Y., E.D. Mich., N.D. Cal., and S.D. Iowa. As in the case of the E.D. Pa., the judgeship recommended for the N.D. Cal. was to replace a temporary judgeship created by the Act of September 14, 1922.

In 1927, the Conference requested an additional judge for the Sixth Circuit, a recommendation in which the Attorney General concurred. See ANNUAL REPORT OF THE ATtORNEY GENERAL OF THE UNITED STATES FOR THE FISCAL YEAR 19274 (1927). In 1928, the Conference requested, and the Attorney General concurred, in requests for an additional (second) judge for the E.D.N.Y, and additional judges for the S.D. Fla. and the Ninth Circuit. See AnNual Report of the Attorney General of the United States for the Fiscal YeAR 19283 (1928). In 1929, the Conference recommended that judges be added to the Fifth Circuit, D. Minn., and S.D. Cal. See ANNUAL REPORT OF THE ATtORNEY GENERAL OF THE United STATES FOR THE FisCAL YEAR 19295 (1929).

174. Specifically citing to the Conference's recommendation, Congress in 1925 enacted legislation authorizing two new judges for the Eighth Circuit. See Pub. L. 68-555, 43 Stat. 1116 (1925); S. REP. No. 68-705, at 1-2, 10-11 (1924). Taft personally testified in favor of the legislation, a fact featured prominently on the floor of Congress. 66 Cong. ReC. 5202 (1925). See Statement of Hon. W.H. Taft, Additional Judges for the Eighth Circuit, Hearing on H.R. 661 before the Committee on the Judiciary of the House of Representatives, 68th CONG. 1st SESS. 1-5 (1924) ("This bill, gentlemen, is part of a recommendation made by the council of judges, which was created under a recent law. ... This council of judges is directed to meet with a view to arranging the business of the country, to make assignments of and exchange judges, and to make recommendations to the district judges. We have assumed to make recommendations for the betterment of the general system of the Federal judiciary where the subject-matter has come immediately under the examination of the members of the council."). The day after passage of the legislation, Judge William Kenyon of the Eighth Circuit wrote Taft that "there is no doubt in my mind as to who is responsible for its enactment, and I am therefore writing you thanking and congratulating you on behalf of this Circuit. Thou art the man." Letter 
from William Kenyon, Judge, U.S. Eighth Cir., to WHT (Mar. 4, 1925) (Taft papers). Taft considered the passage of the act "a great triumph." Letter from WHT to Charles S. Jobes (Mar. 3, 1925) (Taft papers).

In 1926, specifically citing the Conference's recommendation, Congress created a new federal district in Georgia. See Pub. L. 69-307, 44 Stat. 670 (1926); H.R. REP. No. 69-796, at 1 (1926). Taft wrote a friend, "I got the bill through." Letter from WHT to Charles D. Hilles (June 10, 1926) (Taft papers).

The following year, citing the Conference's recommendations, Congress approved seven new judgeships within a two-day period. See Pub. L. 69-700, 44 Stat. 1346 (1927) (additional judge for D. Md.) (S. REP. No. 69-694, at 1 (1926); H.R. REP. No. 69-1814, at 1 (1927)); Pub. L. 69-735, 44 Stat. 1370 (1927) (additional judge for W.D.N.Y.) (S. REP. No. 69-510, at 1 (1926); H.R. REP. No. 69-1821, at 3 (1927)); Pub. L. 69-703, 44 Stat. 1348 (1927) (additional judge for D. Conn.) (S. REP. No. 69512, at 1 (1926); H.R. REP. No. 69-1812, at 1 (1927)); Pub. L. 69-701, 44 Stat. 1347 (1927) (additional judge for E.D. Pa.) (S. REP. No. 69-509, at 1 (1927); H.R. REP. No. 69-1622, at 1 (1926)); Pub. L. 69-747, 44 Stat. 1380 (1927) (additional judge for E.D. Mich.) (S. ReP. No. 69-1490, at 1 (1927); House Committee on the Judiciary, Report to Accompany H.R. REP. No. 69-9043, at 3 (1927)); Pub. L. 69-693, 44 Stat. 1339 (1927) (additional judge for North Carolina) (H.R. REP. No. 69-1842, at 2 (1927)); Pub. L. 69-739, 44 Stat. 1372 (1927) (additional judge for N.D. Ca.) (S. REP. No. 691489, at 2 (1927); H.R. REP. No. 69-1813, at 1 (1927)).

In January 1928, citing the recommendation of the Conference, Congress authorized an additional judgeship for the Southern District of Iowa. See Pub. L. No. 70-6, 45 Stat. 52 (1928); H.R. REP. No. 70-154, at 1 (1928). In May 1928, citing the recommendation of the Conference, Congress authorized an additional judgeship for the Sixth Circuit. See Pub. L. No. 70-353, 45 Stat. 492 (1928); H.R. REP. No. 70-267, at 1 (1928).

In January 1929, citing the recommendation of the Conference, Congress authorized an additional judgeship for the Second Circuit. See Pub. L. No. 70-664, 45 Stat. 1081 (1929); H.R. REP. No. 70-1860 at 1 (1928). Congress also approved a new judgeship for the S.D. Fla. See Pub. L. 70-663, 45 Stat. 1081 (1929). There had been House and Senate reports from the previous year approving the creation of the Florida judgeship, even though the Conference had not yet requested its establishment; in each report Taft was cited as personally approving the creation of the new position. See S. ReP. No. 70-631, at 2 (1928); H.R. ReP. No. 70-1859, at 1-2 (1928). Apparently, Congress preferred to wait until the official 1928 recommendation of the Conference before enacting the legislation.

In February 1929, citing the Conference's urgent recommendations, Congress at last created three additional judgeships for the S.D.N.Y., see Pub. L. 70-820, 45 Stat. 1317 (1929); S. REP. No. 70-1485, at 1-2 (1929); H.R. REP. No. 70-314, at 1-2 (1928), as well as two additional judgeships for the E.D.N.Y. See Pub. L. 70-857, 45 Stat. 1409 (1929); S. REP. No. 70-1487, at 2 (1929); H.R. REP. No. 70-1952, at 1 (1928); 70 CoNG. REC. 1742-48 (Jan. 15, 1929); Greater Efficiency for Federal Courts, N.Y. WORLD, Oct. 8, 1929, at 16 ("It was as a result of [the Judicial Council's] urgings that we were recently given three additional judges in the Southern District of New York and two in the Eastern District.").

In March 1929, Congress approved an additional judge for the Ninth Circuit. See Act of Mar. 1, 1929 Pub. L. 70-864, 45 Stat. 1414 (1929). There is no mention of the Conference in the House and Senate Reports; the House Report, which appears to be in response to a request by the Attorney General, is dated before the Conference's 
The Conference rapidly became the official voice of the federal judiciary, treated with respect by both Congress and the Attorney General. ${ }^{175}$ As Taft observed as early as 1925 , "[t]he truth is I feel as if our Conference was becoming a matter of considerably more importance in Congress and in the press as time goes on, and that we ought to encourage the thought of our importance." 176 The following

1928 recommendation. See H.R. REP. 70-782 (1928). The Senate report, which is dated in January 1929, simply refers to the House report. S. REP. No. 70-1486 (1929).

In May 1930, citing the Conference's recommendation, Congress provided an additional judgeship for D. Minn. See Pub. L. 71-276, 46 Stat. 431 (1930); S. REP. No. 71-648, at 1 (1930) (incorporating by reference the Attorney General's endorsement of the Conference's recommendation); H.R. REP. No. 71-628, at 1 (1930). In June 1930, citing the Conference's recommendation, Congress provided an additional judgeship for the S.D. Cal. See Pub. L. 71-447, 46 Stat. 819 (1930); S. REP. No. 71605 , at 1 (1930) (citing the Attorney General's endorsement of the Conference's recommendation); H.R. REP. No. 71-1767, at 2 (1930).

The upshot is that during Taft's Chief Justiceship the Conference made only one recommendation for an additional judgeship - that for the Fifth Circuit — which was not granted by Congress before the end of 1930. This is a remarkable record of achievement.

175. Indeed, so influential had the Conference become that by the end of the decade Pennsylvania Representative George S. Graham, the powerful Chairman of the House Judiciary Committee, was moved to declare that "[i]t is true that an act of Congress was passed creating this board of senior judges, but I do not hold, and will never consent to it, so far as I am concerned, that it is necessary to get the imprimatur of that board upon every appointment that Congress chooses to make. We did not surrender our legislative function when we created this board. It was not for the appointment of judges but for getting a full and complete view of the situation so that they might consider these matters from every viewpoint, and make such recommendations to Congress as they might deem proper." 70 CONG. REC. 1743 (Jan. $15,1929)$ (remarks of Rep. Graham).

176. Letter from WHT to A.C. Denison, Judge, U.S. 6th Cir. (Mar. 19, 1925) (Taft papers). This was no accident. It was the result of Taft's shrewd bureaucratic infighting. So, for example, Taft wanted the Conference to seize control of the allocation of extra moneys that Congress, at the Conference's request, had appropriated for judicial libraries. See supra note 165. The expenditure of one portion of these funds was explicitly made subject to the approval of the Conference, but the expenditure of a different portion was not. The Conference normally met in the fall, but in 1925, Taft pushed the meeting of the Conference back into June for fear that the latter portion of the funds "will be gone or apportioned before we get here in September." Letter from WHT to A.C. Denison (Mar. 19, 1925) (Taft papers).

Taft's ploy was successful, and the Conference produced a detailed plan for the expenditure of all the funds, ANNUAL REPORT OF THE ATTORNEY GENERAL OF THE UNITED STATES FOR THE FISCAL YEAR 1925 6-8 (1925), which was successfully implemented, in effect asserting judicial control over the distribution of Article III budget appropriations. ANNUAL REPORT OF THE ATTORNEY GENERAL OF THE UNITED STATES FOR THE FisCAL YEAR 19269 (1926). At its meeting in June 1925, Taft told the Conference that "I have a feeling that the recommendations of this Conference 
year, Frankfurter noted that " $[t]$ he actions of the Conference indicate to me the steady growth in its significance and the accumulating influence that it is bound to have with the lower courts and gradually, I am sure, with Congress and the informed thought of the country." 177 By fall 1927, Taft had reason to be gratified at his creation. "A good many people doubted [the Conference's] usefulness," he said, "but all the members of the Conference came to me this time to assure me that their doubts were removed, and it is really accomplishing something." 178

have a good deal of influence. I mean that they are accepted as matters for serious consideration." Report of the Fourth Conference of Senior Judges called by the Chief Justice pursuant to the Act of Congress of September 14, 1922, at 38 (Taft papers).

177. Letter from FF to WHT (Oct. 6, 1926) (Taft papers). See Letter from WHT to FF (Feb. 23, 1926) (Taft papers) ("I think on the whole it has been a quite useful body and that it may grow to be more and more useful as we grow more familiar with what can be done by recommendations to the District Judges and by recommendations to Congress. It gives a unity to the Federal judicial force that I think is valuable, and helps the massing of that force at point where the congestion requires more than the regular number of Judges."); The Judicial Council, supra note 146, at 508 ("No one can read the proceedings of this Conference of Circuit Judges, presided over by the Chief Justice of the United States, without reaching the conviction that a new and important agency has been introduced into the administration of federal justice. Its suggestions to district judges, it may safely be assumed, will be followed. They are not merely the expression of a pious hope, but the program of a body with reason for what it does, with a very strong disposition to do something, and with prestige great enough to insure that its proposals will receive careful attention.").

178. Letter from WHT to Mary [Patten] (Oct. 10, 1927) (Taft papers). See Letter from WHT to Robert A. Taft (Oct. 2, 1927) (Taft papers) ("I am sure [the Conference] is a good thing, that it solidifies the Federal Judiciary, that it brings all the district judges within a mild disciplinary circle, and makes them feel that they are under real observation by the other judges and the country, and it enables the judiciary to express itself in respect of certain subjects in such a way as to be helpful to Congress. A good many of them came to me this time to say that when the Conference was created, they did not think we could do anything, but they admit that they were wrong."). After the 1927 conference, Judge J. Warren Davis, who had attended representing the Third Circuit, wrote Taft to say, "You have made that conference worth while and its influence will be felt in the speedy disposition of 'dead' cases and cases which ought not be delayed in reaching the Supreme Court. You have the ability to dispatch business with a rare charm and effectiveness." Letter from J. Warren Davis, Judge, U.S. Third Cir., to WHT (Nov. 2, 1927) (Taft papers).

Among the early doubters of the Conference was the powerful and cantankerous Senior Judge of the Eighth Circuit, Walter H. Sanborn. In 1923 he had written his former colleague Van Devanter that " $[\mathrm{t}]$ here is more danger of causing delays and wasting time than there is hope of facilitating the administration of justice. The time and labor of the Circuit and District Judges are all needed in the actual work of the courts and it seems to me they are uselessly frittered away by conferences of a few days of men who do not meet each other constantly and to whom many of the numerous changes that idle men suggest are pressed for adoption. I am personally 
In 1927, the Conference was able to express official approval of its own work. "The condition of business in the district courts of all the country is much more satisfactory than it was a year ago," it said. ${ }^{179}$ "The courts as now organized in the United States are able, we think, to take care of business as it comes in." 180 This was a real achievement. Figure 7, which charts the total caseload of federal district courts from fiscal 1915 through fiscal 1930, illustrates the rising caseload that in fiscal 1918 had far outpaced the ability of federal judges to keep up. The consequent steep rise in judicial backlog, beginning in fiscal 1920 and peaking in fiscal 1923, posed a serious crisis for the federal judiciary. Beginning in fiscal 1925, however, arrears began to decline for the remainder of the decade, as federal district courts were able to terminate more cases than were initiated. ${ }^{181}$ Figure 8 suggests that these changes were largely driven by increased criminal prosecutions (chiefly for prohibition violations), which district judges began to terminate faster than their initiation in fiscal 1924. ${ }^{182}$

pretty tired of combating the constant endeavors to change the rules and practices of the courts for I know, as you do, that every change - good or bad, delays the administration of justice because the methods of procedure are known to the Judges and lawyers who do the work now, and every change is new and at first unknown to them all." Letter from Walter H. Sanborn to WVD (Jan. 3, 1923) (Van Devanter papers). Sanborn asked Van Devanter to "say nothing about my expressions to the Chief Justice or any other person. I feel about the whole matter as you evidently do, but I do not want to oppose Chief Justice Taft in what he evidently thinks will be of great benefit." Id. It is no accident that when Taft authored the Conference's 1927 report, he pointedly quoted Sanborn's assessment that " $[t]$ he condition of the business throughout the circuit is far more satisfactory than it has been at any time within the last five years." ANNUAL REPORT OF THE ATTORNEY GENERAL OF THE UNITED STATES FOR THE FISCAL YEAR 19278 (1927).

179. ANNUAL REPORT OF THE ATtORNEY GENERAL OF THE UNITED STATES FOR THE FISCAL YEAR 19277 (1927).

180. In 1928, the Conference again reported, "it was clear to the conference that the condition of business in all the courts was satisfactory, and showed that there were enough judges to do the business." ANNUAL REPORT OF THE ATTORNEY GENERAL OF THE UNITED STATES FOR THE FISCAL YEAR 19284 (1928).

181. In 1926, the Conference declared that it "is gratified at finding that substantial progress had been made during the past year in reducing the delays and congestion of business which recently added judgeships had been created to remove." ANNUAL REPORT OF THE ATTORNEY GENERAL OF THE UNITED STATES FOR THE FISCAL YEAR 19266 (1926).

182. In 1926, the Conference reported, "As to the criminal cases, the evidence before the conference, the statistical reports from the Department of Justice, the reports of the district judges, and the knowledge of the members of the conference lead to the conclusion that this result has been due to the increase in the number of judges, to the policy of the Department of Justice in discouraging the prosecution of insignificant and unimportant alleged violations of the law, and to the activity of 
Figure 7. Total District Court Cases (Attorney General's Reports)

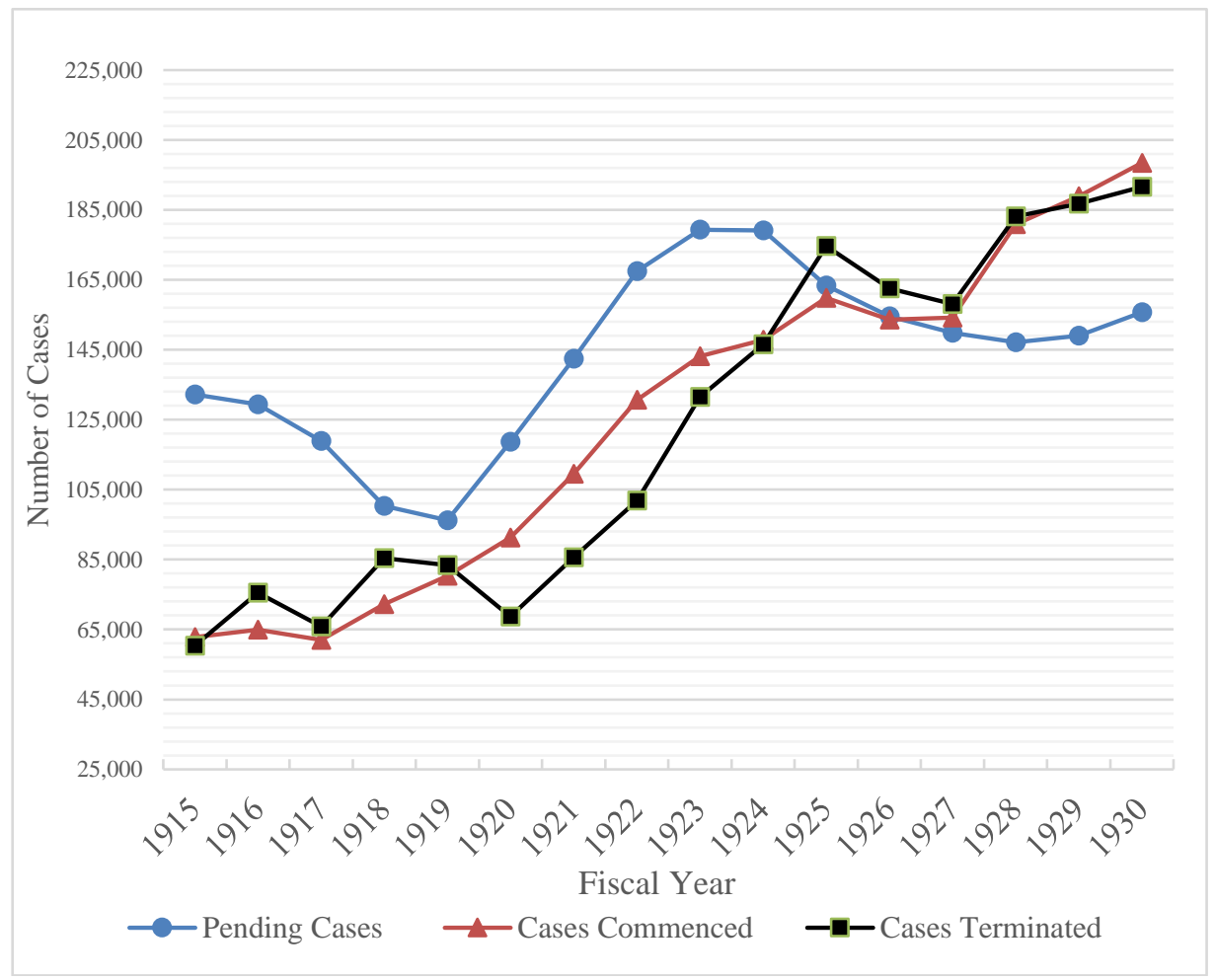

courts and district attorneys in seeking to remove from the docket the dead cases that can not be tried for lack of evidence." Id. Figure 9 suggests that although the sharp rise in bankruptcy cases that began in fiscal 1921 (as a result of the post-war depression) were an important source of the crisis leading to the 1922 Act, district courts began to catch up with these cases in fiscal 1925 and that the level of arrears did not increase for the remainder of the decade. As Figure 10 illustrates, civil cases to which the United States was a party constituted in absolute terms a relatively small proportion of the total federal docket; yet the number of such cases also began to rise in fiscal 1918 and continued to climb throughout the decade. In part this reflected the government's shift toward prohibition remedies that involved civil injunctions. In fiscal 1927, there was a sharp rise in terminated cases over initiated cases, which might reflect the Conference's recommendations about dismissing inactive cases. See supra note 164. Figure 11 demonstrates that although there was a rise in arrears between fiscal 1919 and fiscal 1922, the absolute level of arrears for private litigation remained more or less level for the remainder of the decade. 
Figure 8. Criminal Prosecutions by the United States in District Courts (Reports of the Attorney General)

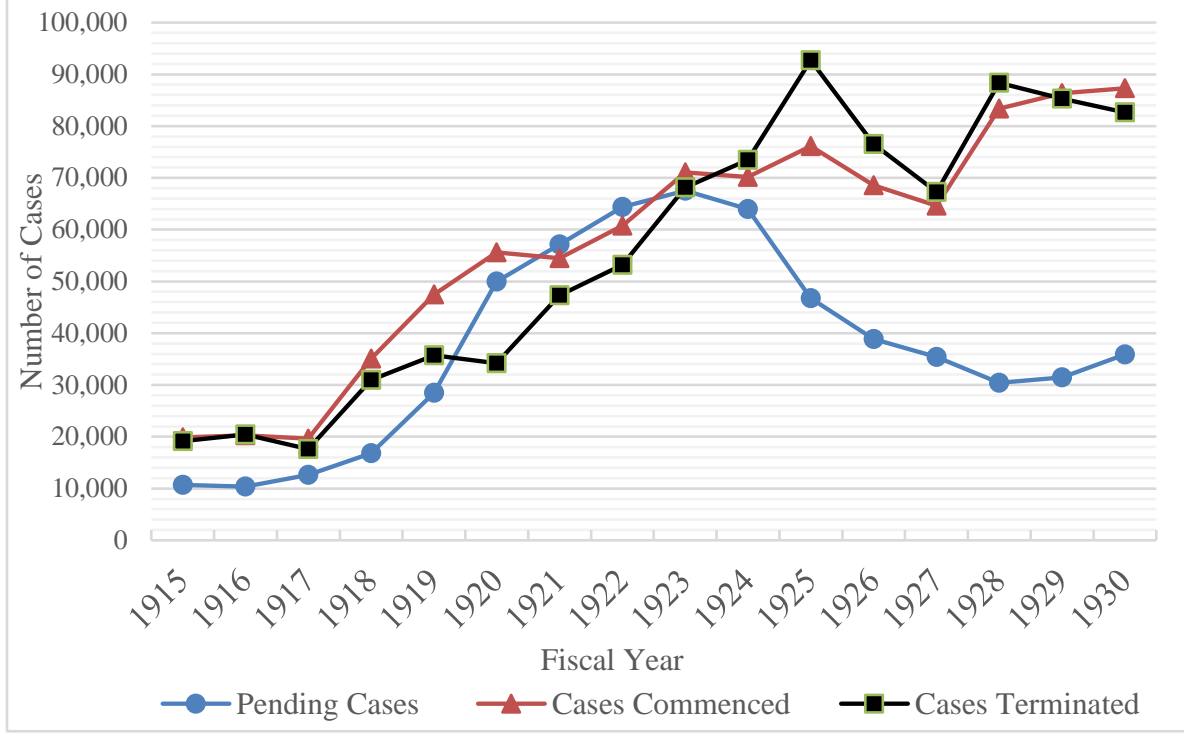

Figure 9. District Court Bankruptcy Cases (Attorney General Reports)

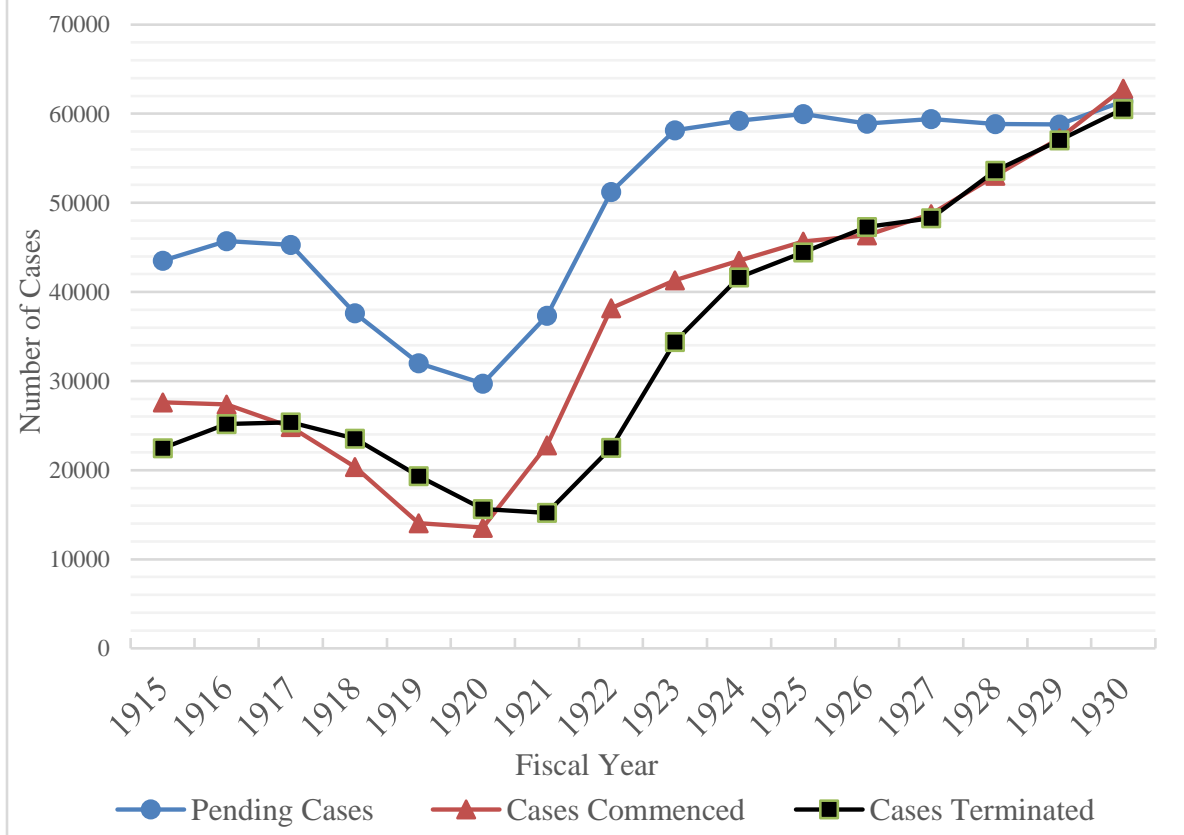


Figure 10. District Court Civil Cases to Which United States Is a Party (Reports of the Attorney General)

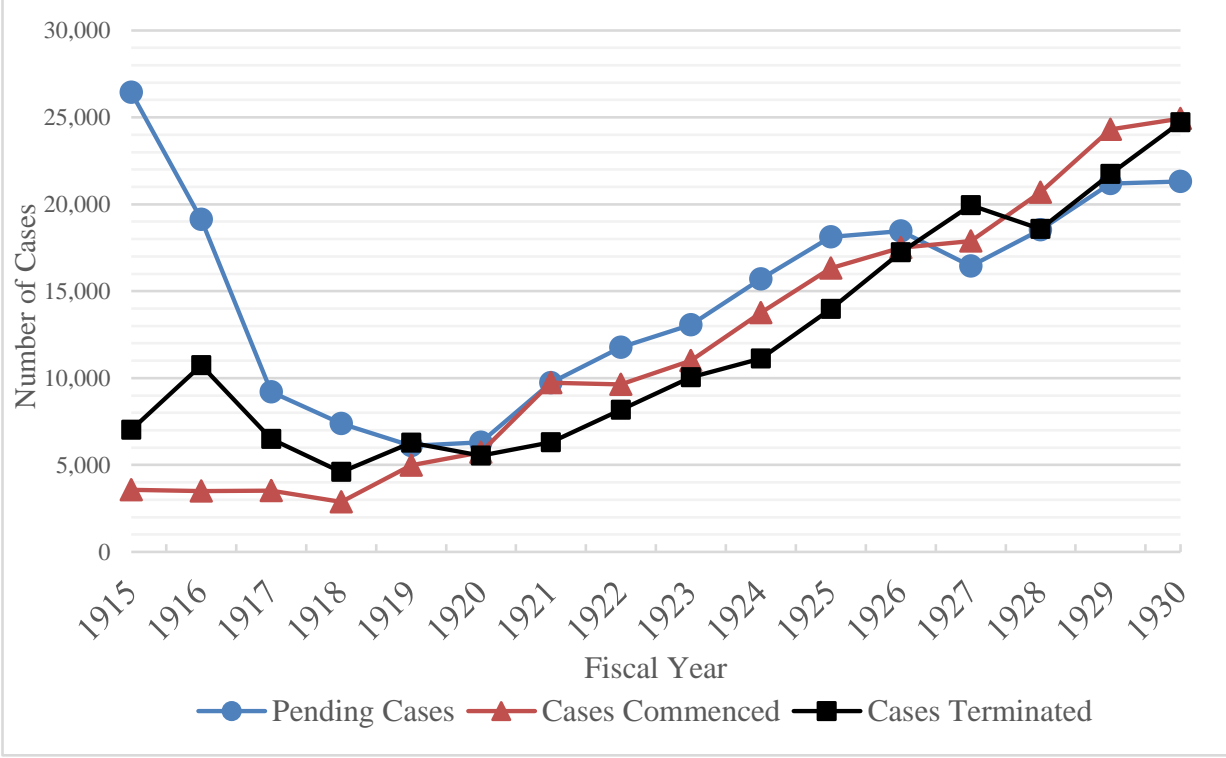

Figure 11. District Court Cases to Which the United States Is Not a Party (Reports of the Attorney General)

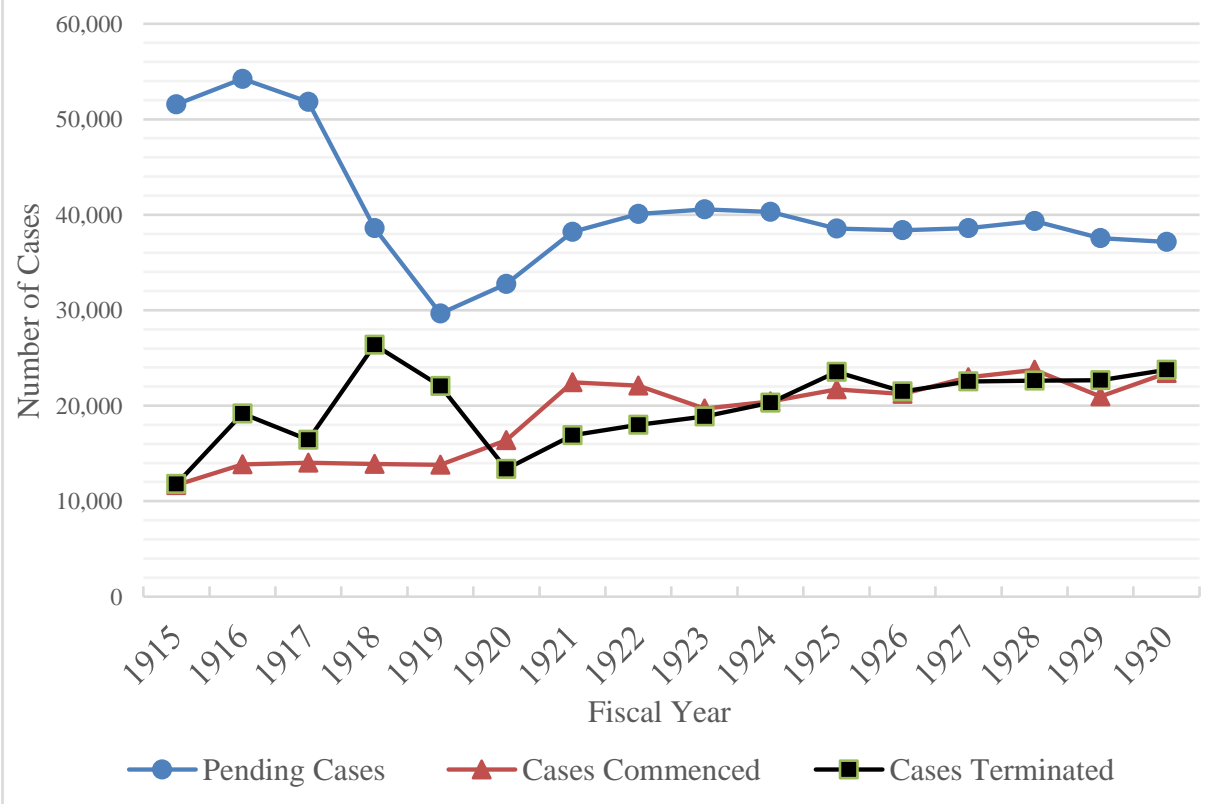




\section{Despite Taft's hopes, ${ }^{183}$ it is likely that the manifest improvement} in the dockets of federal district courts that occurred during the 1920s

183. See, e.g., Letter from WHT to Warren F. Martin (Jan. 31, 1923) (Taft papers) ("I am exceedingly anxious to organize a campaign in New York City and mass as many Judges as we can, and give them a sample of what can be done."); Letter from WHT to Henry Wade Rogers, Senior Judge, U.S. Second Cir. (Feb. 2, 1923) (Taft papers) ("What I wish . . .to do is to come over to New York and have an interview with you and your fellow Judges, especially the District Judges, to see if we can not mass an attack on those discouraging arrears that you have in the Southern District. I shall go over the whole list of Judges in other Circuits with all of you and see if I can not get enough to be formidable in this matter. I would like to give a demonstration of what can be done if Congress will only lend a hand in the matter of disposition of business. . . I have this matter very much at heart."); Letter from WHT to Henry Wade Rogers (Feb. 7, 1923) (Taft papers) ("I mean business about your district.”); Letter from WHT to Learned Hand, Judge, S.D.N.Y. (Feb. 25, 1923) (Taft papers) ("I am writing over the country to see where I can get Judges for you, and have had quite a correspondence with Judge Rodgers . . . I don't know that I can get seven Judges, but I am going to make an effort to get as many as I can."); Letter from Learned Hand to WHT (July 2, 1923) (Taft papers) ("As you will see, we are not making great advances on the docket, although there has been continuous work done on it. I may say for your private ear that some of the out of town judges do not work quite so speedily as the local ones. Perhaps they do their work more carefully and better, but when it comes to counting numbers on the docket the results do appear good."); Letter from Henry Wade Rogers to WHT (July 18, 1923) (Taft papers) ("The progress which has been made in the Southern District of New York during the last year has not availed much and the situation is still bad. A number of Judges have been here from outside districts.... They do not seem to have made much of an impression on the congested situation."); Letter from WHT to John C. Oldmixon (Jan. 6, 1924) (Taft papers) ("The congestion at New York is a disgrace to the administration of Federal justice. The congestion there is perfectly dreadful. The additional Judges appointed to other partes [sic] of the country are making a real advance, but the mass of business in the city of New York is such that it seems most difficult to make progress. For that reason, the Judicial Council of Circuit Judges which met last September in Washington, and of which I am Chairman, recommended that two additional Judges be created for New York City."); Letter from Augustus N. Hand to WHT (Jan. 22, 1925) (Taft papers) ("[O]ur work is seriously behind in this district. ... [W]e are getting ... further behind in our work. ... "); Letter from WHT to Augustus N. Hand (Jan. 23, 1925) (Taft papers) ("The plan of transferring Judges from one District to another is good but it is not enough, and certainly not for a District that needs additional Judges all the time."); Letter from WHT to Arthur C. Denison, Senior Judge, U.S. 6th Cir. (Jan. 23, 1925) (Taft papers) ("Calling in Judges from other Districts is all right for temporary congestion, but nothing will help New York except a substantial addition to the judicial force."); Letter from WHT to John G. Sargent, U.S. Attorney Gen. (Mar. 20, 1925) (Taft papers) ("The Senior Circuit Judges will be here on the 9th of June, and of course they will bring word with them as to those Judges within their jurisdiction who can be used elsewhere. The truth is that there are very few Judges who can be used. The number of Judges who are furnished by the Omnibus Bill is not enough, and constant inquiry made of the Circuit 
was not primarily due to the ability to transfer federal judges created by the 1922 Act. "[T]he assignment of judges from outside circuits turned out to be only an alleviating factor in congested districts, and not a very large one at that." 184 Instead the vast increase in judicial manpower authorized by the Act, as well as the steady augmentations of judicial strength later in the decade, were probably chiefly responsible for overcoming the congestion crisis of the early 1920 s.

One should not lightly disregard, however, the intangible factors created by the Conference, of which Taft was acutely aware. Having district judges report the state of their dockets to senior circuit judges, who in turn met together as a group to discuss the national state of the judiciary, brought district judges for the first time into what Taft called "a mild disciplinary circle" that made "them feel that they are under real observation by the other judges and the country." 185

On the positive side, it made district judges feel noticed and their work valued, so that for Taft the Conference was "an instrument for creating harmony, coordination and unified action by the hundred or more Judges engaged in the courts of first instance and intermediate appeal." 186 It was a means "to come in touch with the Federal Judges

Judges indicates that it is very difficult for any Senior Circuit Judge to spare a man from his Circuit. I would like to talk with you on this subject."); Augustus N. Hand to WHT (Mar. 3, 1926) (Taft papers) ("I believe we are seeing things move here. . . I think the Admiralty and Civil Jury dockets will be brought from two years down to one from the date of issue of the summer recess and Equity will I hope be about the same. This will be a big gain. It is due to your help in getting outside Judges through the winter which we greatly appreciate."); Letter from WHT to Augustus N. Hand (May 12, 1926) (Taft papers) ("I am very sorry about the Judges, but I have raked and scraped, and I don't know what more I could do."); Augustus N. Hand to WHT (May $31,1927)$ (Taft papers) ("I shall always remember your personal kindness and powerful assistance in helping us here to reduce the terrible arrears of business. We have got the admiralty down from four or five years to one. . . the Civil Jury is, I think, down from two and a half years to fifteen months; the Criminal Docket pretty well clear up - Equity, alone, shows no improvement and is nearly two years behind.").

184. Chandler, supra note 135 , at 339 .

185. Letter from WHT to Robert A. Taft (Oct. 2, 1927) (Taft papers).

186. Letter from WHT to FF (Aug. 21, 1925) (Taft papers). So, for example, Judge James Madison Morton Jr. wrote Taft to say that "I have just received and read the recommendations of the Judicial Conference. I wish you could be a District Judge for a while just to know what excellent work you and the Conference are doing. The recommendation last year about liquor cases,--that the Federal Courts should entertain only the more important ones,--was of the greatest assistance in dealing with the liquor situation. It gave the District Judges solid standing ground from which to urge that course on the United States Attorneys, who are rather inclined to prosecute everybody for everything lest they be accused of favoritism or remissness. The recommendation this year about the use of conspiracy indictments is absolutely sound and much 
of the country, so that we may feel more allegiance to a team and do more teamwork." 187 Taft believed that forging such "a closer union of the Federal judicial forces" could "not but make for better administration." 188 It produced "teamwork, uniformity in action and an interest by all the judges in the work of each district." 189

For Taft, this aspiration to unify and inspire the federal judiciary attached directly to the institutional responsibilities of the Chief Justiceship, on whose shoulders rested the need for achieving "more solidarity of action among the Federal Judges, so that they shall feel that we are all working toward the same end." 190 As Taft wrote to one district judge,

We have a tremendous amount of work to carry on, and if we don't coordinate and haven't an esprit, we shall lose opportunity to do the work well ... . I have been very anxious to have all the members of the Federal Judiciary realize that we are remanded to the top, and that whatever we can to [sic] here in Washington to help, we will do. ${ }^{191}$

Taft was therefore always "glad to keep in touch with District Judges. They are the wheel horses of our system, and I want them to know that they have the deepest sympathy in their efforts in the dispatch of business in the members of the Supreme Court. Don't

needed." Letter from James Madison Morton Jr., Judge, U.S. Dist. Mass., to WHT (June 22, 1925) (Taft papers). Or consider the letter sent to Taft by Judge Frank S. Dietrich: "[T] he administration of justice is deeply indebted to you for your service in bringing about a greater measure of co-ordination in the work of the several courts. I share with others the feeling that what you are doing is of great constructive value. The recommendations of the Conference have given prestige to the efforts of the local judge in expediting trials and eliminating delays incident to practices strongly intrenched [sic] in the traditions of the Bar; already waste of time in impaneling juries has been reduced to a minimum." Letter from Frank S. Dietrich, Judge, U.S. Dist. Idaho, to WHT (Jan. 12, 1927) (Taft papers).

187. Letter from WHT to Horace D. Taft (Dec. 30, 1921) (Taft papers). Judge John F. Sater wrote Taft that the Conference "will get us all in touch as never before." Letter from John F. Sater, Judge, S.D. Ohio, to WHT (Aug. 23, 1921) (Taft papers).

188. Letter from WHT to Francis E. Baker, Judge, U.S. 7th Cir. (Oct. 5, 1922) (Taft papers). See Letter from WHT to Mrs. Frederick J. Manning (Mar. 25, 1923) (Taft papers).

189. Letter from WHT to John F. Sater, Judge, S.D. Ohio (Aug. 27, 1921) (Taft papers).

190. Letter from WHT to Mrs. Frederick J. Manning (Mar. 25, 1923) (Taft papers). As Taft wrote to Augustus Hand, "[y]ou need not be grateful to me for anything I can do to help you, for we are in the same boat, and we all have to row, or ought to." Letter from WHT to Augustus N. Hand (Nov. 14, 1925) (Taft papers).

191. Letter from WHT to Frank S. Dietrich, Judge, U.S. Dist. Idaho (Jan. 17, 1927) (Taft papers). See Letter from WHT to Merrill E. Otis (Apr. 9, 1925) (Taft papers) ("I take a warm interest in every District Judge."). 
hesitate to write me whenever you have a suggestion or inquiry to make."192 Taft liked to write judges to ask them to return "a long gossipy letter so that I may acquire intimate knowledge of the situation" 193 and to lament that "we in the Court here in Washington do not have greater opportunity to meet in the flesh the Judges who are on the firing line in the Federal Judiciary." 194

In return, district judges throughout the country expressed their appreciation for Taft's attention and concern. As Learned Hand wrote Taft in 1923, "It is a great comfort to know the interest that you take. To be frank, we have never felt it before your incumbency," 195 adding a year later that "[a]s I have had occasion to tell you before, I feel I have a vested interest in your being Chief Justice, because you are the first Chief Justice that ever recognized such things as District Courts except when they were officially brought to their attention to reverse." $" 196$

From this perspective, the Conference was merely a mechanism through which Taft could fulfill the larger obligations of executive leadership that he understood as implicit in the role of Chief Justice. Although Taft deftly deployed the Conference to achieve goals he believed necessary for the improvement of federal courts, ${ }^{197}$ he was not willing to confine his personal efforts to those sanctioned by the Conference. So, for example, when Congress in 1927 authorized an additional judgeship for the Northern District of New York, ${ }^{198}$ the

192. Letter from WHT to John S. Partridge, Judge, U.S. N.D. Cal. (Jan. 22, 1925) (Taft papers).

193. Letter from WHT to William B. Gilbert, Judge, U.S. 9th Cir. (Dec. 15, 1924) (Taft papers).

194. Letter from WHT to John M. Cotteral, Judge (May 19, 1926) (Taft papers). "I wish you to know that we here at the Nation's Capital," continued Taft, "are fully conscious of the debt that we and the country owe to you District Judges." Id.

195. Letter from Learned Hand, Justice, U.S. Supreme Court, to WHT (Mar. 1, 1923) (Taft papers). Hand added, "I had two chats with Justice Holmes while I was at Washington .... A And may I add that your right ear must have been burning at the time he spoke of you, and he has had some experience with Chief Justices?" Id.

196. Letter from Learned Hand, Justice, U.S. Supreme Court, to WHT (Feb. $8,1924)$ (Taft papers).

197. So, for example, when Taft became convinced that the Southern District of New York needed a third extra judge, see supra note 183, he wrote Charles Evans Hughes asking him to petition Congress for legislation, adding "I shall do what I can here, and I shall get the Conference of Senior Circuit Judges . . . to take action." Letter from WHT to Charles Evans Hughes (Mar. 25, 1925) (Taft papers). Sure enough, after its 1925 meeting the Conference recommended a third judgeship for the Southern District of New York. See supra note 173.

198. See Pub. L. No. 69-741, 44 Stat. 1374 (1927). 
Conference had not yet recommended any such judgeship. Yet the Senate Report accompanying the legislation quotes a letter from Attorney General John G. Sargent specifically invoking the authority of the Chief Justice:

Although the northern district of New York was not included among the districts for which the conference of senior circuit judges has recommended additional district judges, Chief Justice Taft, who presides over the conference, has, since the last meeting of the conference, specially examined the situation in the northern district of New York and concluded that an additional district judge is needed there. The Chief Justice says:

"I have been examining the statistics of the cases in the northern district of New York and in the western district, and I am bound to concede that the showing is strong for an additional judge in the northern district as well as in the western district." 199

199. S. REP. No. 69-1557, at 2 (1927). In its 1927 Report, the Conference retroactively endorsed Taft's recommendation. "Congress at its last session provided for a judge in the northern district of New York which the conference did not recommend, but which it is glad to have had provided." ANNUAL REPORT OF THE

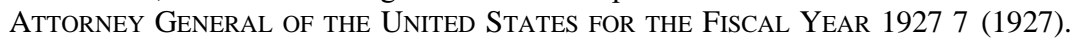
Other examples of Taft lobbying for judgeships outside the approval of the Conference include Taft's support for an additional judge for the Western District of Michigan to compensate for the incapacitated Clarence Sessions, even though the Conference had not made any such recommendation. See Pub. L. 68-423, 43 Stat. 949 (1925); H.R. REP. No. 68-1427, at 1 (1925) ("This bill has the approval of Chief Justice Taft, who, according to the hearings, has personally investigated the physical condition of Judge Sessions."); Taft's support for an additional judgeship for the Southern District Florida, see supra note 174; and Taft's support for the appointment of a replacement judgeship for the District of Minnesota due to the unexpected suicide of Judge John McGee, who had been appointed to a expiring position under the 1922 Act. See Pub. L. 68-528, 43 Stat. 1098 (1925); H.R. REP. No. 68-1540, at 1 (1925) (citing "a communication received from the Chief Justice of the United States which shows the necessity for immediate enactment of this legislation"); Letter from Walter H. Sanborn to WVD (Feb. 19, 1925) (Van Devanter papers); Letter from WVD to Walter H. Sanborn (Feb. 27, 1925) (Van Devanter papers) ("The Chief Justice and I just returned from the Capital where we again saw Mr. Graham. . . Mr. Graham was intending to make an effort to get . . . the Minnesota district judge bill through . ..."); Letter from Walter H. Sanborn to WHT (Feb. 25, 1925) (Taft papers).

Taft was not reluctant, however, to deter other judges from lobbying for additional judgeships outside of the proper channel of the Conference. So, for example, he wrote to Senior Judge Henry Wade Rogers:

I shall be glad to forward your letter to the Attorney General on the subject of an additional Judge in the Western District of New York. I have no doubt that he is interested, but I very much doubt the wisdom of bringing the matter up in this way, and think that it ought to come through the Council of Judges, just as the other recommendations did. I don't think the Attorney General would recommend it in the absence of such action by the Council, and I am not sure that I would advise him to do so, because we 
When specific incidents of egregious judicial delay or abuse were brought to his attention, Taft took it upon himself to take action. In 1927, for example, he wrote to prod District Judge John A. Peters into deciding a stale case:

I write in the interests of the administration of justice, and for the reputation of the Federal Judiciary, that you dispose of the patent case which you now must have had at hand and submitted to you for more than four years. As a fellow member of the Federal judiciary, I urge that you drop everything else and decide this case. ... We none of us can afford to justify the complaints of delays in awarding just rights to litigants. Of course I write this letter with no assumption that I may exercise direct authority over you in the discharge of your duties, but as the head of the Federal Judiciary I feel that I do have the right to appeal to you, in its interest and in the interest of the public whom it is created to serve, to end this indefensible situation. ${ }^{200}$

ought not to take action in respect to which there is no hope of successful issue, or to recommend something which may diminish the effect of that which we have already recommended. I shall delay writing to the Attorney General until I hear from you again.

Letter from WHT to Henry Wade Rogers, Senior Judge, U.S. Second Cir. (Nov. 21, 1923) (Taft papers). The following year, in 1924, the Conference recommended an additional judgeship for the Western District of New York, see supra note 173, which was authorized in 1927. See supra note 174.

200. Letter from WHT to John A. Peters, Judge, U.S. Dist. Me. (Oct. 11, 1927) (Taft papers). Taft wrote a similar letter to Judge William N Runyon: "It has come to me in a semi-official way that you have still undecided a patent case ... which was argued in November, 1925. . . I I am sure that you are anxious like all of us to justify the existence of the Federal Judiciary, and believe in the useful functions that it performs, and I merely write this not by way of criticism or by way of assuming to exercise any statutory authority I have, but to let you know that the delay in the case to which I refer is made the basis for adverse comment." Letter from WHT to William N. Runyon, Judge, U.S. Dist. N.J. (Mar. 12, 1928) (Taft papers). Runyon was apparently perturbed by Taft's unexpected letter. He wrote back a long, self-justifying letter, expressing "deep concern" at "the semi-official character of your information ... implying as it did a criticism not born of personal or professional partisanship, but proceeding from impersonal sources, and undertaken in the fulfillment of a duty." Letter from William N. Runyon to WHT (Mar. 17, 1928) (Taft papers). Taft replied in a most kind way:

All I wanted to know was that you were doing the best you could, as I should judge you were doing, and that the matter would work out. . . [D]on't yield too much to the fear that you may by an early decision reach a wrong result. Courts of Appeal are provided to remedy mistakes in the lower courts. . . I know a Judge intimately, Judge Hammond, who was an excellent Judge but who thought he was writing for posterity, and almost waited until posterity had come before he got opinions rendered. I don't mean to say that these faults are yours, but I only point out that some very good Judges forget the fact that courts are to decide cases and decide them promptly, in the earnest desire to decide them right. 


\section{MANAGING THE SUPREME COURT}

Incorporating responsibilities such as these into the obligations of the Chief Justiceship vastly expanded the scope of the position. The primary role of the Chief Justice had heretofore been to manage the Supreme Court. Taft learned about the unique obligations of that work almost immediately upon assuming office.

After returning to Canada upon taking the oath of office on July 12, 1921, Taft had received an urgent telegram from Senior Associate Justice Joseph McKenna on July 30 informing him that Deputy Clerk Henry McKenney had passed away. ${ }^{201}$ This posed a serious difficulty for the Court, because its Clerk, James D. Maher, had died the month before on June 3. At the time, federal law provided that the Clerk could be appointed only by the Court. ${ }^{202}$ If the Clerk died, the Deputy Clerk could "perform the duties of the clerk in his name until a clerk is appointed and qualified." 203 The death of Deputy Clerk McKenney, however, left the Clerk's office, as Assistant Clerk William R. Stansbury telegraphed Taft, "now without an official head and no one authorized to issue official papers." ${ }^{204}$ Yet because the Court was dispersed for its summer vacation, it could not be gathered to appoint a new Clerk.

Taft promptly returned to Washington on July 30 to meet with McKenna. Telegraphic consultation with those Associate Justices who could be contacted proved unhelpful, which, as Taft wrote, "only shows what McKenna assured me that the other members of the Court

Letter from WHT to William N. Runyon (Mar. 19, 1928) (Taft papers). In such situations, Taft was not above invoking the unique authority of an appointing President. Thus he wrote to Judge Ferdinand A. Geiger:

A suggestion has come to me with reference to a case ... which is pending before you. I have no doubt that there are reasons for the delay, which it is said to have been about three years. Of course I have no authority as Chief Justice to make suggestions of this kind to other Judges, but our relations are such, and my pride in you as one of my appointees is so great, that I thought it only a prompting of warmest friendship and admiration for me to call this to your attention.

Letter from WHT to Ferdinand A. Geiger, Judge, U.S. Dist. E. Wis. (Nov. 17, 1927) (Taft papers).

201. Letter from Joseph McKenna, Justice, U.S. Supreme Court, to WHT (July 30, 1921) (Taft papers). McKenney was sixty-nine years old and had been an employee of the Court for the past fifty-two years.

202. 36 Stat. $1152(1911)$.

203. 36 Stat. 1153 (1911).

204. Letter from William R. Stansbury to WHT (July 30, 1921) (Taft papers). 
expect me to attend to the executive business of the Court and not bother them." ${ }^{205}$ McKenna impressed the point on his new Chief:

\begin{abstract}
McKenna said I must realize that the Chief Justiceship was an office distinct from that of the Associates in executive control and was intended to be and all of the Associates recognized it, that in judicial decisions all were equal but in management I must act and they would all stand by if ever question was made. ${ }^{206}$
\end{abstract}

Taft boldly and promptly resolved "to do something without statutory authority" 207 and appoint Stansbury "de facto deputy clerk," 208 exacting "a common law bond from him to protect everybody." 209

Throughout his decade on the Court, Taft managed the Court with fluency and ease. "I think Taft is all the better Chief Justice for having been President," Holmes wrote his friend Harold Laski. ${ }^{210}$ "He works hard, keeps everything moving, and gets the work done with good temper and humor."211 Taft placed the vigilant Brandeis on the Committee of Accounts, along with Van Devanter and McReynolds; Brandeis proved continuously forthcoming with recommendations about improving the Court's finances. ${ }^{212}$ Taft reformed Court

205. Letter from WHT to Helen Herron Taft (Aug. 3, 1921) (Taft papers).

206. Id.

207. Id.

208. Letter from WHT to William R. Stansbury (Aug. 3, 1921) (Taft papers).

209. Letter from WHT to Helen Herron Taft (Aug. 3, 1921) (Taft papers).

210. Letter from OWH to Harold Laski (June 6, 1926), in 2 HOLMES-LASKI LeTters: The CORRESPONDENCE OF Mr. Justice HolmeS AND HAROLD J. LASKI 19261935848 (Mark DeWolfe Howe ed., 1953) [hereinafter 2 HoLMES-LASKI CORRESPONDENCE] Upon Taft's appointment, Holmes had written Laski, "Taft I think will do well as CJ-the executive details, which, as I have said, are the matters upon which the C.J. most counts as such, will be turned off with less feeling of friction and more rapidly, I think, than with his predecessor, especially after he had become so infirm. As to opinions we shall see." Letter from OWH to Harold Laski (Oct. 9, 1921), in HOLMES-LASKI CORRESPONDENCE, supra note 45, at 373; see Letter from OWH to Nina Gray (Oct. 12, 1921) (Holmes papers).

211. Letter from OWH to Harold Laski (Nov. 13, 1925), in HolMES-LASKI CORRESPONDENCE, supra note 45, at 797.

212. This was especially important given that a portion of the Clerk's income continued to be taken from fees charged to litigants. Letter from WHT to Members of the U.S. Supreme Court (Feb. 12, 1928) (Van Devanter papers). See, e.g., Letter from WHT to LDB (Mar. 12, 1923) (Taft papers); Letter from WHT to WVD (Mar. 12, 1923) (Taft papers); Letter from WHT to LDB (Mar. 2, 1924) (Taft papers); Letter from WHT to JCM (Mar. 6, 1924) (Taft papers); Letter from WHT to William R. Stansbury, Clerk, U.S. Supreme Court (Mar. 6, 1924) (Taft papers); Letter from William R. Stansbury to WHT (Mar. 17, 1924) (Taft papers); Letter from WHT to LDB (Mar. 19, 1924) (Taft papers); Letter from WHT to William R. Stansbury (Mar. 23, 1924) (Taft papers); Letter from LDB to WHT (Mar. 28, 1924) (Taft papers); Letter from WHT to LDB (Apr. 8, 1924) (Taft papers); Letter from WHT to LDB 
procedures to make them more rational. ${ }^{213} \mathrm{He}$ conceived and implemented a policy that would expedite all criminal cases. ${ }^{214} \mathrm{He}$

(Dec. 10, 1924) (Taft papers); Letter from LDB to WHT (Jan. 4, 1925) (Taft papers); Letter from WHT to LDB (Nov. 30, 1925) (Taft papers); Letter from William R. Stansbury to WHT (Dec. 4, 1926) (Taft papers); Letter from LDB to WHT (Oct. 13, 1927) (Taft papers); Letter from LDB to WHT (Dec. 20, 1928) (Taft papers).

213. See, e.g., Arthur C. Denison, Senior Judge, U.S. 6th Cir. to William Howard Taft (Taft papers); Letter from WHT to Arthur C. Denison, Senior Judge, U.S. 6th Cir. (Oct. 6, 1922) (Taft papers); WHT to William R. Stansbury, Clerk, U.S. Supreme Court (Oct. 8, 1922) (Taft papers).

214. 1925 Sup. CT. J. 326, 326 (June 1, 1926) ("To expedite the hearing of criminal cases upon the docket of this court, brought here by writ of error directly from State courts or from those courts by appeals from writs of habeas corpus in Federal courts, it is ordered that all cases of this kind upon the docket be advanced for hearing and set during the October sessions of this court at the October, 1926, term. It is further ordered that appeals in Federal criminal cases arising under the laws of the United States and now upon the docket of this court, be also advanced for hearing at the October sessions for the October term of 1926."); Supreme Court Stops Delay in Criminal Case Hearings, N.Y. TIMES, Oct. 20, 1926, at 1 ("Chief Justice Taft gave notice on the opening of the Supreme Court today that hereafter no unnecessary delays would be permitted in the final disposition of criminal cases appealed to that body. He stated that the Court had decided to do everything possible to expedite hearings and decisions in criminal cases and prevent delays on its docket."); Letter from WHT to Charles P. Taft II (Nov. 28, 1926) (Taft papers) ("We are pursuing a policy of bringing for immediate hearing every criminal cases that is ready, whether State or Federal. We don't propose to have our Curt made a refuge for convicted criminals to delay imprisonment, and it is curious to see how many of them fade out as having nothing in them the minute we require them to be set for a hearing."); Letter from WHT to Robert A. Taft (Nov. 28, 1926) (Taft papers) ("We find that it has been too often the case that a defendant convicted in a State court would get into our Court by some hook or crook of constitutional suggestion, and then that the case would be forgotten and not pressed to our attention by the State officers. We therefore have adopted the rule of putting these cases out for hearing just as soon as they are ready."); Letter from WHT to Newton D. Baker (Jan. 15, 1928) (Taft papers); Gaines v. Washington, 277 U.S. 81, 87 (1928) ("It has not been the practice of the court to write opinions and state its reasons for denying writs of certiorari, and this opinion is not to be regarded as indicating an intention to adopt that practice, but, in view of the fact that the court has deemed it wise to initiate a practice for speedily disposing of criminal cases in which there is no real basis for jurisdiction in this court, it was thought proper to make an exception here, not to be repeated, and write an opinion."); Letter from WHT to the Brethren (May 11, 1928) (Taft papers) (explaining how the opinion in Gaines is designed to "serve notice that we are engaged in expediting our disposition of criminal convictions and not allow a refuge here for delay"); Herbert F. Goodrich, American Law Institute Adopts its First Official Draft, 14 A.B.A. J. 245 , 246 (May 1928) (providing remarks of William Howard Taft: "We in our court have determined that those gentlemen who have been unfortunate enough to be convicted in the State courts and in the lower Federal courts are not going to have a period of rest and contemplation before they begin to serve the State in a close relation through us, and we, therefore, are advancing every criminal case that comes into court. When 
created a week at the outset of the Term in which hearings were suspended while the Court considered the certiorari petitions "which have collected during the summer." ${ }^{215} \mathrm{He}$ sought mightily to reduce Court fees. ${ }^{216} \mathrm{He}$ effectively pushed for legislation regularizing the salary of the Court Reporter, which had heretofore been partially paid out of contracts with private publishers. ${ }^{217} \mathrm{He}$ rationalized the funding

we adjourn for the summer we shall have heard every case on the docket of a criminal character. (Applause.)").

215. Letter from WHT to George D. Seymour (Aug. 11, 1925) (Taft papers); Draft Memorandum [June 7, 1927] (Taft papers); Letter from WHT to George D. Seymour (Oct. 16, 1927) (Taft papers) ("[T]he truth is that I have been overwhelmed by the flow of business in certioraris and in submitted cases that we have had at the beginning of this term. It is the legitimate outcome of our new law, the Act of February 13,1925 , and is an indication that it is working as we wished it to work, but it reveals the necessity of our changing the method we have had at the opening of the term in the disposition of business. We shall have to devote about ten days to certioraris alone, without hearing arguments."); Letter from WHT to Robert A. Taft (Oct. 16, 1927) (Taft papers); Letter from WHT to Ernest Knaebel (Sept. 18, 1928) (Taft papers); Gregory Hankin, U.S. Supreme Court Under New Act, 12 J. AM. JudiCATURE SoC'Y 40, 43 (Aug. 1928).

216. Letter from WHT to Members of the U.S. Supreme Court (Feb. 12, 1928) (Van Devanter papers) ("We ought to take steps at once to reduce substantially the cost to litigants in our Court."); Letter from WHT to Members of the U.S. Supreme Court (Feb. 13, 1928) (Stone papers); Letter from WHT to Members of the U.S. Supreme Court (Feb. 15, 1928) (Stone papers); Letter from WHT to Members of the U.S. Supreme Court (Feb. 23, 1928) (Stone papers); Letter from WHT to James M. Beck (Sept. 23, 1923) (Taft papers); Letter from WHT to Loyal E. Knappen, Judge, U.S. 6th Cir. (Jan. 15, 1924) (Taft papers); Letter from WHT to William R. Stansbury, Clerk, U.S. Supreme Court (Dec. 12, 1925) (Taft papers); Letter from WHT to LDB (Dec. 7, 1926) (Taft papers); Letter from William R. Stansbury to WHT (Dec. 16, 1926) (Taft papers); Letter from LDB to WHT (Dec. 16, 1926) (Taft papers); Letter from WHT to LDB (Dec. 18, 1926) (Taft papers) (discussing how over the objection of Stansbury and Brandeis, Taft "would be glad . . . to make the experiment to see whether we could not reduce our printing fee 20 per cent . . . I I am itching to reduce expenses to the litigants in our Court"); Letter from LDB to WHT (Dec. 18, 1926) (Taft papers) (conceding to Taft's plan); Letter from WHT to JCM (Dec. 18, 1926) (Taft papers); Letter from WHT to JCM (Jan. 4, 1926) (Taft papers); Letter from WHT to William R. Stansbury (Jan. 20, 1927) (Taft papers); Letter from WHT to Charles Elmore Cropley, Clerk, U.S. Supreme Court (Dec. 22, 1928) (Taft papers); Letter from WHT to Charles Elmore Cropley (Jan. 7, 1929) (Taft papers).

217. Pub. L. No. 67-272, 42 Stat. 816 (July 1, 1922); H. REP. No. 67-963, at 3 (1922); Jurisdiction of Circuit Courts of Appeals and United States Supreme Court: Pay of Supreme Court Reporter, HEARING ON H.R. 10479 BEFORE THE COMMITTEE ON the Judiciary of the House of Representatives, 67th Cong. 2d Sess. (Mar. 30, 1922), at 9-12; Publication of U.S. Supreme Court Reports, 8 A.B.A. J. 457 (1922); Pub. L. No. 69-157, 44 Stat. 344 (Apr. 29, 1926); Letter from WHT to Senator George Norris (Jan. 4, 1929) (Taft papers). The legislation also that gave the Chief Justice 
of the Marshall's office. ${ }^{218} \mathrm{He}$ fought hard and continuously for necessary space within the Capitol building where the Supreme Court was then housed. ${ }^{219}$

Taft also struggled to make the Supreme Court a more outwardly-facing institution. He had copies of the Court's opinions sent to all State supreme courts ${ }^{220}$ because, as he said, "it is of the highest importance that we judges in the courts of last resort, State and National, who are engaged in interpreting the law, should be on close

supervision over expenses in the Reporter's office and provided that the printing of the Supreme Court Reports be done at the Government Printing Office.

218. Pub. L. No. 70-268 (1928); S. REP. No. 70-436 (1928); H.R. REP. No. 70300 (1928); H.R. REP. No. 70-1099 (1928); 69 CONG. REC. 5726 (Apr. 2, 1928); Letter from Frank K. Green to WHT (Apr. 13, 1928) (Taft papers) (reform due to "the kindly and untiring efforts of the Chief Justice"); Letter from WHT to Frank K. Green (Apr. $15,1928)$ (Taft papers).

219. See, e.g., Letter from WHT to Charles Curtis, Senator, U.S. Senate (Feb. 26, 1923) (Taft papers) ("I hope you are not going to deny us in the Supreme Court the space which we need for the Clerk's Office. With the very large Senate Office Building you ought to be willing to let the Supreme Court have at least breathing space ... . You have taken back all the rooms but three that were assigned to us for the use of the Judges. In our conference room the shelves have to be made so high that it takes an aeroplane to reach them. But two of the justices have rooms in the Capitol .... [Y]ou might be willing to keep your Senate Committees within space which is reasonable in view of the real needs of the judicial branch of government."); Letter from Charles Curtis to WHT (Feb. 27, 1923) (Taft papers); Letter from WHT to Charles Curtis (Feb. 28, 1923) (Taft papers) ("[W]e will take the room which you have assigned to us, but I shall continue to protest against the fact that you do not allow the Supreme Court to have space enough for its records. The room which the Senate barber shop now occupies in the Capitol should be given to the Court . . . "); Letter from Charles Curtis to WHT (Mar. 1, 1923) (Taft papers) ("I know how much the Supreme court needs additional space and I tried to get them two rooms, but we were unable to make arrangements to get but the one. The Chairman of the subcommittee and myself worked together in this matter and did everything possible. Personally, I am in favor of erecting a new building for the Supreme Court so that they will have all the room the Court needs, not only for the Court, but for all its offices.").

220. See, e.g., Letter from WHT to John C. Anderson, Judge, Ala. Supreme Court (Oct. 18, 1921) (Taft papers); see Letter from Wendell W. Mischler to William R. Stansbury, Clerk, U.S. Supreme Court (Nov. 8, 1921) (Taft papers); Letter from WHT to James M. Beck, U.S. Solicitor Gen. (Dec. 23, 1921) (Taft papers). The Chief Justice of Kentucky wrote Taft to say that "[t]o you, Mr. Chief Justice, I am informed is due the credit of this much needed reform in the method of publishing these opinions. It will be received with gratification by all active members of the legal profession." Letter from Flem D. Sampson, Judge, Ky. Court of Appeals, to WHT (Jan. 13, 1921) (Taft papers). 
terms with each other and do team-work." ${ }_{221} \mathrm{He}$ also authorized the distribution of the Court's opinions to major press organizations. ${ }^{222}$

\section{REFORMING THE JURISDICTION OF THE SUPREME COURT}

It was apparent to Taft, however, that the reform which the Supreme Court most needed entailed legislative redefinition of its jurisdiction. ${ }^{223}$ As Figure 12 indicates, the docket of the Court had become unmanageable by the end of the 1880s. The Court was then three years behind on its caseload. To provide relief, Congress passed the Evarts Act in 1891, which created the United States Circuit Courts of Appeals, ${ }^{224}$ and which for the first time authorized the Court to use the discretionary writ of certiorari to determine which cases (within predetermined categories) it would choose to review from these new lower courts. ${ }^{225}$ By using the writ, the Court could determine every

221. Letter from WHT to Judge Flem D. Sampson, Judge, Ky. Court of Appeals (Jan. 16, 1921) (Taft papers). Taft declined, however, to send opinions to lower state appellate judges. As he wrote to a state judge, "[o]ur appropriation for printing is running rather low, and I am not sure whether I can extend the sending of our opinions to the Judges of your Appellate Court. I took a great interest in bringing them to the Judges of the Supreme Courts of all the States, and have loaded down our printing bills a little beyond what Congress has allowed us." Letter from WHT to Julius C. Travis, Justice, Ind. Supreme Court (Apr. 19, 1922) (Taft papers); Letter from Robert von Moschzisker, Chief Justice, Pa. Supreme Court, to WHT (Nov. 13, 1922); Letter from WHT to Robert von Moschzieker (Nov. 14, 1922); Letter from WHT to William R. Stansbury, Clerk, U.S. Supreme Court (Nov. 14, 1922) (Taft papers); Letter from William R. Stansbury to WHT (Nov. 15, 1922).

222. Letter from WHT to Herbert Little (Dec. 11, 1928) (Taft papers).

223. "We need legislation to help us." Letter from WHT to George Roe Lockwood (Jan. 9, 1923) (Taft papers).

224. Taft was himself among the very first judges appointed to the newly created Court of Appeals for the Sixth Circuit.

225. 26 Stat. 826, 828 (1891); Edward A. Hartnett, Questioning Certiorari: Some Reflections Seventy-Five Years After the Judges' Bill, 100 CoLuM. L. REV. 1643, 1650-57 (2000); Mason Mazzone \& Carl Emery Woock, Federalism as Docket Control, 94 N.C. L. REV. 7, 24-26 (2015); William Howard Taft, The Jurisdiction of the Supreme Court Under the Act of February 13, 1925, 35 YALE L.J. 1, 1 (1925). The Evarts Act was badly crafted. McMillan Contracting Co. v. Abernathy, 263 U.S. 438, 441 (1924) ("The Act of 1891 was passed to relieve this court from a discouraging congestion of business. It was evidently intended that the Circuit Court of Appeals should do a large part of the appellate business. The act was not happily drawn in defining the division of it between those courts and this court, and many difficulties have arisen."). After studying the record in preparation for circulating an opinion in McMillan, Taft wrote a long memorandum to the Court:

I have wrestled with this Case ... and spent more brain matter, whether gray or not, over it than it deserves ... . I am satisfied ... after a full review of the authorities, ... that no ... logical exposition of our decisions can be 
aspect of any case that it wished to hear. Although the Evarts Act provided immediate and effective relief, Figure 12 demonstrates that by 1905 the docket and arrears of the Supreme Court had once again begun to swell.

Figure 12. Appellate Caseload of Supreme Court (Reports of the Attorney General)

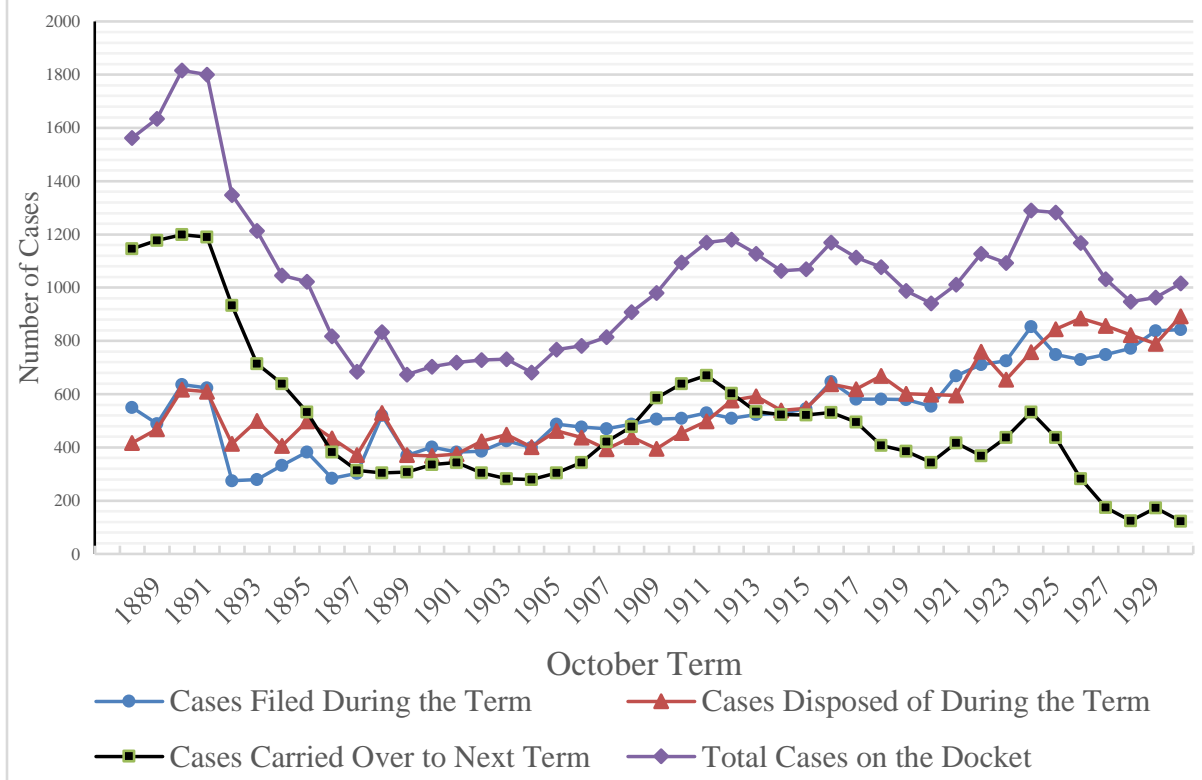

made, and that the distinctions that I attempted can not be reconciled with a number of them. This was the view which Brother McReynolds took in the beginning, and he was right. I don't know whether it is wise for us to speak as frankly as I do of the lack of logic in our decisions .... The difficulty of harmonizing the language of the statute with our decision reminds me of the story which John Vertrees of Tennessee told me, to express his view of the white and negro social question in the South. He said there was a creek in the neighborhood of his old birthplace called Saskatchequarle Creek, and that a stranger coming to visit Dr. Robinson, an old-timer of that vicinity, asked the Doctor how he spelled the name of the creek. The Doctor's reply was, "Some spell it one way and some do spell it another, but in my judgment there air no correct way of spellin' it." .. . All I can say about the matter is that I know more on the subject than I did before, and that knowledge adds to the fervency of my prayer that the whole field of our appellate jurisdiction and of the Circuit Court of Appeals shall be reformed, so that a wayfaring man, though a fool, may follow the lines of each division.

Letter from WHT to Colleagues (Dec. 31, 1923) (Taft papers). 
At about that time, Taft articulated a radical new theory of the function of the Supreme Court. In an important 1908 article, he argued:

Generally in every system of courts there are a court of first instance, an intermediate court of appeals and a court of last resort. The court of first instance and the intermediate appellate courts should be for the purpose of finally disposing in a just and prompt way of all controversies between litigants. So far as the litigant is concerned, one appeal is all that he should be entitled to; the community at large is not interested in his having more; for the function of the court of last resort, usually called the Supreme Court is not primarily for the purpose of securing a second review or appeal to the particular litigant whose case is carried to that court. ... [T] he chief reason for granting such a review is to enable the Supreme Court to lay down general principles of law in the interpretation of State or Federal constitutions or statutes, or in the application of the common law, for the benefit and guidance, not of the particular litigant affected, but of the communities at large. Therefore, the appellate jurisdiction of the Supreme Court should generally be limited to those cases which are typical and which give an opportunity to the court to cover the whole field of the law upon the subject involved. The highest function of the Supreme Court of the United States is the interpretation of the Constitution of the United States, so as to guide the other branches of the Government and the people of the United States in their construction of the fundamental compact of the Union. ${ }^{226}$

The Supreme Court, Taft asserted, should not be seen as a final appellate court. Instead it should be understood as the supervisor of the system of federal law. Taft at first advanced this theory primarily to diminish delays and expense in litigation. Reducing the mandatory appellate jurisdiction of the Supreme Court, Taft stressed, would decrease the cost of litigation and hence equalize access to justice as between the rich and the poor. ${ }^{227}$

226. William H. Taft, Delays and Defects in the Enforcement of Law in This Country, 187 N. AM. REV. 851, 851-52 (1908).

227. Taft explained:

Many people who give the subject hasty consideration regard as the noblest product of human wisdom a system of appeals, by which a suit can be brought before a justice of the peace, and carried through the several intermediate courts of appeal to the Supreme Court of the State. How many legislative halls have rung with the eloquence of defenders of the oppressed and the poor, in opposing laws which were designed to limit the appeals to the Supreme Court to cases involving large sums of money or questions of constitutional or other important law! Shall the poor man be denied the opportunity to have his case re-examined in the highest tribunal of the land? Never! And generally the argument has been successful. In truth, there is nothing which is so detrimental to the interests of the poor man as the right which, if given to him, must also be given to the other and wealthier party. It means two, three and four, and in some cases even five and six years of 
By 1910, however, the crisis in the Supreme Court's docket had become unmistakable, as is illustrated by Figure 12. Taft then explicitly connected his theory of discretionary review to the necessity of reducing the Court's impossible workload. In his Annual Message to Congress, President Taft advocated legislation that would reduce the Court's mandatory appellate jurisdiction:

No man ought to have, as a matter of right, a review of his case by the Supreme Court. He should be satisfied by one hearing before a court of first instance and one review by a court of appeals ... The Supreme Court is now carrying an unnecessary burden of appeals of this kind, and I earnestly urge that it be removed. ${ }^{228}$

Taft continued to advocate for this reform after he stepped down from the presidency. In 1916, he argued that it was necessary to strip the Court of mandatory jurisdiction except in cases involving constitutional questions so that the Court could keep up with the everexpanding business of a growing nation:

The Supreme Court has great difficulty in keeping up with its docket. The most important function of the court is the construction and application of the constitution of the United States. It has other valuable duties to perform in the construction of statutes and in the shaping and declaration of general law, but if its docket is to increase with the growth of the country, it will be swamped with its burden, the work which it does will, because of haste, not be of the high quality that it ought to have, and the litigants of the Court will suffer injustice because of delay. For these reasons the only jurisdiction that it should be obliged to exercise, and which a litigant may, as a matter of course, bring to the court, should be questions of constitutional construction. By giving an opportunity to litigants in all other cases to apply for a writ of certiorari to bring any case from a lower court to the Supreme Court, so that it may exercise absolute and arbitrary discretion with respect to all business but constitutional business, will enable the court so to restrict its docket that it can do all its work, and do it well. ${ }^{229}$

litigation. Could any greater opportunity be put in the hands of wealthy persons or corporations to fight off just claims and to defeat, injure or modify the legal rights of poor litigants, than to delay them in securing their just due for several years? I think not.

Id. at 855 .

228. 46 Cong. ReC. 16, 25 (1910) (President's Annual Message).

229. Taft, The Attacks on the Court, supra note 106, at 18; see also Taft, Address of the President, supra note 109, at 384. A glance at Figure 13 well illustrates the causes of Taft's concern. The Court's docket and arrears began to climb beginning in the 1920 Term. The short-lived increase in the Court's docket after 1914 may have been caused by the Act of December 23, 1914, 38 Stat. 790. See Hartnett, supra note 73, which expanded the scope of the Court's jurisdiction, although it did so entirely through the increased availability of discretionary certiorari review. That is likely why the increase in the number of cases filed during the 1915 and 1916 Terms was almost 
Figures 12 and 13 demonstrate that just as Taft became Chief Justice, the docket and arrears of the Court began yet another period of steep increase. The newly installed Chief Justice told the Chicago Bar Association in December 1921 that the "situation is rendered critical by the accumulating mass of litigation growing out of the war, and especially of claims against the Government which, if allowed to come under the present law to the Supreme Court, will throw us hopelessly behind." 230 "[T] here must be some method adopted by which the cases brought before that Court shall be reduced in number," Taft argued, and yet allow the Court to "retain full jurisdiction to pronounce the last word on every important issue under the Constitution and the statutes of the United States and on all important questions of general law with respect to which there is a lack of uniformity in the intermediate Federal courts of appeal." ${ }_{231}$

entirely matched by the number of cases terminated. The decrease in the Court's total docket and arrears between the 1916 and 1920 Terms was probably caused by the Act of September 6, 1916, Pub. L. 258, 39 Stat. 726, which made discretionary some of the Court's heretofore mandatory jurisdiction, in part by removing the large number of small Federal Employers' Liability Act cases from its mandatory jurisdiction. See Hartnett, supra note 225, at 1658-60. The 1916 Act, as Taft later wrote Frankfurter, "was brought about through the active recommendation of Mr. Justice McReynolds, who had been Attorney General, and whose acquaintance with the Judiciary Committee of both the House and Senate enabled him to secure its passage. It was a step toward the reduction of the obligatory jurisdiction of the Court and the enlargement of its jurisdiction by certiorari." Letter from WHT to FF (May 11, 1926) (Taft papers).

230. The Chief Justice, 5 CHI. B. Ass'N REC., Dec. 1921, at 11-12.

231. Id. at 11-12. Taft stated, "Some of us are working on a proposed bill to simplify the statement of the jurisdiction of the Supreme Court and have it embraced in one statute." Id. at 11. Taft's address is reproduced as Three Needed Steps of Progress, supra note 137. It is noteworthy that in January 1922, Taft had actually authored a letter in support of a bill increasing (to a minor extent) the jurisdiction of the Supreme Court. See Pub. L. 67-144, 42 Stat. 366 (1922); 62 CoNG. REC. 1227-28 (1922) (remarks of Representative Boies) ("We took the precaution to submit this matter to the Supreme Court of the United States, knowing they were a little jealous of their jurisdiction, and I have copies of the letters here from the Chief Justice of the Supreme Court of the United States and also the Attorney General showing approval of the amendment."). 
Figure 13. Appellate Jurisdiction of the Supreme Court (Reports of the Attorney General)

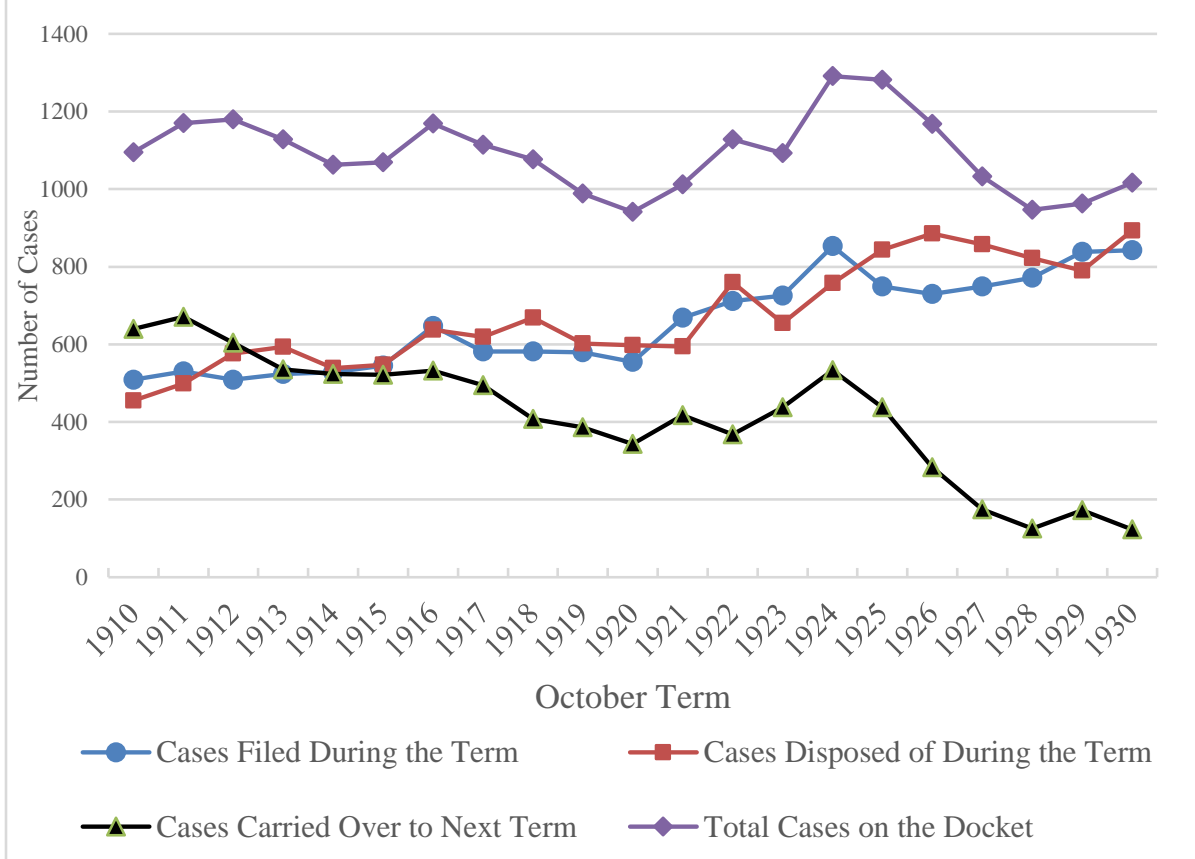

In August 1922, Taft reported to the Annual Convention of the $\mathrm{ABA}$ that there was then "an interval of 15 months between the filing of a case in the court and its hearing.... The members of the Supreme Court have become so anxious to avoid another congestion like that of the decade before 1891, that they have deemed it proper themselves to prepare a new bill amending the jurisdiction of the Supreme Court and to urge its passage." ${ }^{232}$ Ruling out other methods of reducing congestion in the Supreme Court docket, like imposing "heavy costs" or eliminating diversity or federal question jurisdiction in lower federal courts, ${ }^{233}$ Taft contended that the only feasible method for

232. Taft, Possible and Needed Reforms, supra note 101, at 602.

233. Id. at 603-04. Taft no doubt had in mind a long speech recently delivered in Virginia by Senator Thomas J. Walsh of Montana on June 8, 1922, in which he professed to "look forward to the eventual abolition of the jurisdiction of the Federal courts in civil causes because of diversity of citizenship or alienage or because the controversy involves a Federal question.” 62 CONG. REC. 8549 (June 12, 1922) (statement of Sen. Thomas J. Walsh). Walsh argued that proposed legislation to increase the Court's discretionary jurisdiction would create a tidal wave of certiorari petitions that would swamp the Court and actually increase the congestion of its 
docket. He contended that there should be no writs of certiorari at all allowed in cases from the Circuit Courts of Appeals, but instead that the Court would have to hear mandatory appeals coming from those courts, which would be limited to the determination of federal questions. $I d$. In effect, therefore, Walsh was proposing to remove the Supreme Court from the formulation of general common law.

Justices McReynolds and Day immediately wrote to Walsh objecting to his conclusions. Letter from JCM to Thomas J. Walsh, Senator, Mont. (June 30, 1922) (Walsh papers) ("If a hearing must be given \& oral argument offered in every Federal question involved in every suit important things must be neglected or delayed beyond reason.... The general theory of the pending bill I think is good. After a litigant has had a hearing in all the State courts or in two Federal Courts the matter may properly end unless there is something about the cause which the court can see is of general importance. The use of certiorari is the only practical way of which I am aware by wh. this end can be reached. And personally I incline to think it will be necessary at some time to confine the jurisdiction of the court almost wholly to causes taken up on certiorari. ... The great fundamental purpose of the Supreme Court, as I understand, is to settle the law for guidance of courts \& counsel and this I think makes it necessary to relieve the court from a multitude of unimportant things wh. consumes time \& strength which should [be] devoted elsewhere. The suggestions you make concerning the limitation of the jurisdiction of the lower Federal Courts have much in their favor. But as a practical matter, are they possibilities? I incline to think not."); Letter from WRD to Thomas J. Walsh (July 10, 1922) (Walsh papers) ("I have thought for some time that it would be wise to increase the certiorari power of the Court along the line embodied in the bill now before Congress. That course will enable the Court to winnow the wheat from the chaff and to give its attention more fully to the great questions of constitutional law and kindred matters which constitute the great purposes for which the Court was created."). Neither Justice was inclined to debate the merits of Walsh's proposal to take the Court out of the business of declaring general common law.

General common law emerged from what the historian Edward Purcell has aptly called "the system of corporate diversity litigation," which both in its doctrine and operation strongly favored corporate interests against employees and ordinary persons. See Edward A. Purcell, JR., Litigation and Inequality: Federal DIVERSITY JURISDICTION IN INDUSTRIAL AMERICA, 1870-1958 8-9 (1992). The system was in fact one of the chief causes of the dissatisfaction with federal courts that Taft was so concerned to allay. See Taft, Criticisms of the Federal Judiciary, supra note 99 , at 642. Federal courts typically declared general law when exercising diversity jurisdiction. Taft was thoroughly committed to diversity jurisdiction, because he regarded it as essential to national financial markets. As he told the ABA in his August address:

I venture to think that there may be a strong dissent from the view that danger of local prejudice in state courts against non-residents is at an end. Litigants from the eastern part of the country who are expected to invest their capital in the West or South will hardly concede the proposition that their interests as creditors will be as sure of impartial judicial consideration in a western or southern state court as in a federal court. The material question is not so much whether the justice administered is actually impartial and fair, as it is whether it thought to be so by those who are considering the wisdom of investing their capital in states where that capital is needed for the promotion of enterprises and industrial and commercial 
progress. No single element - and I want to emphasize this because I don't think it is always thought of - no single element in our governmental system has done so much to secure capital for the legitimate development of enterprises throughout the West and South as the existence of federal courts there, with a jurisdiction to hear diverse citizenship cases.

Taft, Possible and Needed Reforms, supra note 101, at 604.

Taft was so committed to the system of corporate diversity litigation that in his first term on the Court he authored the pivotal case of Terral v. Burke Construction Co., 257 U.S. 529 (1922), which overturned past precedents and invalidated statutes in approximately half the States that allowed foreign corporations the privilege of doing business in a State only on the condition that they waive their right to resort to federal diversity jurisdiction. Id. at 532. In Terral, Taft even referred to a foreign corporation's "constitutional right . . . to resort to the federal courts." Id. The thought that there was a constitutional right to invoke diversity jurisdiction, either by way of removal or otherwise, was so outlandish that the Court explicitly repudiated it less than a year later. "The right of a litigant to maintain an action in a federal court on the ground that there is a controversy between citizens of different states is not one derived from the Constitution of the United States . . . . Certainly it is not a right granted by the Constitution." Kline v. Burke Constr. Co., 260 U.S. 226, 233 (1922). Terral nevertheless had a powerfully negative affect on the lives of numerous ordinary consumers, especially in litigation involving insurance companies. See PURCELL, supra, at 205-13.

Brandeis, who was close to Senator Walsh, also vigorously opposed "the system of corporate diversity litigation" and hence diversity jurisdiction itself. Letter from LDB to FF (Apr. 2, 1925), in BRANDEIS FRANKFURTER CORRESPONDENCE, supra note 41, at 200. Brandeis noted that Taft "sp[oke] feelingly" on the subject of diversity "whenever it came up. I think his point is theoretical, like much of the economists mouthing of the 'rational man.' Of course, the bankers \& still less the investors, do not give the subject of litigation any thought when they make loans. What rate they get depends mainly on the money market, and the credit of the State or municipality. And we are reminded frequently that it is not the federal courts of the West and South, but those of New York in which the bankers' counsel are mainly interested. Moreover, they \& everybody within every State ought to be made to care whether the State tribunals are worthy \& not seek the "easier way." Letter from LDB to FF (May 10, 1928), in BRANDEIS FRANKFURTER CORRESPONDENCE, supra note 41, at 331-32. It may have been because of this underlying alliance with Walsh that when Taft asked Brandeis for his support in expanding the Court's discretionary jurisdiction, Brandeis replied: Bill.

Re your suggestion of a letter of approval of the pending Jurisdiction

A clear majority of the Court approve of it wholly. I think it has many admirable features. But a study of our experience during the last eight years has raised in my mind grave doubt whether the simple expedient of expanding our discretionary jurisdiction is the most effective or the safest method of securing the needed relief. For this reason, it cannot be stated that I individually approve the bill.

I am willing that you should say that the Court approves the billwithout stating whether or not individual members approve it. For, in relation to proposed legislation directly affecting the Court, the Chief Justice, when supported by a clear majority, should be permitted to speak 
control of the Supreme docket was the expansion of its discretionary jurisdiction. ${ }^{234}$

for it as a unit; and differences of view among its members should not be made a matter of public discussion.

Letter from LDB to WHT (Nov. 30, 1924) (Taft papers). See Jurisdiction of Circuit Courts of Appeals and of the Supreme Court of the United States: Hearing on H.R. 8206 Before the H. Comm. on the Judiciary, 68th Cong. 2d Sess. (Dec. 18, 1924), at 29 (statement of Chief Justice William Howard Taft) ("I am told by all the members that I can say that the court is for the bill. There may be one member-I do not think there are more - who is doubtful about it, or, I should say, doubtful as to its efficacy; but he said to me that I could say the whole court were in favor of the bill.").

Taft immediately forwarded Brandeis's note to Van Devanter, saying: "Because Walsh is opposed to it, as he told me, because he talked with Walsh, and because he always wishes to appear on the off side and a champion of the offsiders, he declines to help us. This at least seems to me to be the situation." Letter from WHT to WVD (Dec. 1, 1924) (Van Devanter papers); Letter from WHT to Robert A. Taft (Dec. 14, 1924) (Taft papers) ("I tried to enlist Brandeis in this business, but I smoked him out and found that while he was willing to have the court reported as favoring the bill, he would not himself do anything and intimated doubts about it. That is because Walsh of Montana is against the bill. He tries hard to be a good fellow but he misses it every little while."); Letter from WHT to Charles P. Taft II (Feb. 8, 1925) (Taft papers) ("Brandeis was reluctant, but we ran over him. He evidently sympathized with Walsh."). The day after the Bill was signed, Brandeis wrote Frankfurter that "I still think that (except as to Ct of Claims), the bill doesn't touch the most serious unnecessary burdens incident to the prior jurisdictional acts as construed." Letter from LDB to FF (Feb. 14, 1925), in BRANDEIS FRANKFURTER CORRESPONDENCE, supra note 41 , at 193. The exact nature of Brandeis's objections cannot now be determined, but he might have had in mind the distinction between "facial" challenges to the constitutionality of state statutes, and "as applied" challenges to such statutes. Dahnke-Walker Milling Co. v. Bondurant, 257 U.S. 282 (1921). Brandeis might also have had in mind the construction of the word "statute" in the new Bill. See John P. King Mfg. Co. v. City Council of Augusta, 277 U.S. 100, 102 (1928).

Walsh's opposition to the Judges' Bill eventually collapsed, possibly because the Bill came to a vote in February 1925, at precisely the moment when Walsh was being bested in his struggle to prevent Stone's confirmation to the Court. As Taft remarked to his brother, "Walsh got worsted in his fight with A.G. Stone so he pulled in his horns and the bill passed the House one day and the Senate the next with Walsh helping and coming into conference with us." Letter from WHT to Horace D. Taft (Mar. 1, 1925) (Taft papers). Walsh did insist on an amendment to the bill that retained mandatory jurisdiction in some cases coming to the Court from the Circuit Courts of Appeals, but in Taft's view the amendment "did not amount to much." Letter from WHT to Robert A. Taft (Feb. 8, 1925) (Taft papers); Letter from LDB to FF (Feb. 14, 1925), in BRANDEIS FRANKFURTER CORRESPONDENCE, supra note 41, at 193 (the Bill "got through by making some changes insisted upon by T.J. Walsh, the C.J. tells me. I have not seen what these changes are, but I think from what he remembered \& particularly from the fact that VanD approved, that they should be satisfactory").

234. The great advantage of discretionary jurisdiction, as distinct from deciding cases through summary appeals, see Hartnett, supra note 225, at 1705, 1715, is that denials of certiorari imply nothing about the substantive merits of a case. See 
The upshot was Taft's second great achievement as Chief Justice, the Judiciary Act of February 13, 1925, ${ }^{235}$ often called the Judges' Bill because it was drafted by the Court itself. ${ }^{236}$

United States v. Carver, 260 U.S. 482, 490 (1923) ("The denial of a writ of certiorari imports no expression of opinion upon the merits of the case, as the bar has been told many times."). In Price Fire \& Water Proofing Co. v. United States, 261 U.S. 179 (1923), for example, Van Devanter requested that Brandeis remove from his circulated draft a citation to "certiorari denied," commenting: "Fear this may convey to some an impression that denial of certiorari may be taken as a precedent of some weight. Merely call it to your attention. Am not insistent." Brandeis removed the reference. (Brandeis papers). But see James Craig Peacock, Purpose of Certiorari in Supreme Court Practice and Effect of Denial or Allowance, 11 A.B.A. J. 681, 683 (Nov. 1929) (referring to the "impression that the denial of certiorari by the Supreme Court has somehow added to the sanction or authority of the decision cited. But one who has ever chanced to be present in the Supreme Court when some hapless counsel has referred to such a case as a decision of the Supreme Court or as having gained in that way even the slightest additional weight as an authority will never again labor under such an illusion. Such an impression is, however, a natural one, and . . . more or less generally prevalent even among otherwise well informed lawyers").

From the perspective of Justices under a certiorari regime, cases must be examined "[n] ot of course so thoroughly as to decide them in our minds, but fully enough to decide whether they ought to be brought before us; and of course, I should say, in most cases incidentally to have an opinion whether the judgment below is right or wrong." Letter from OWH to Lewis Einstein (May 19, 1927), in THE HolMESEINSTEIN LETTERS: CORRESPONDENCE OF MR. JUSTICE Holmes AND LEWIS EINSTEIN 1903-1935 267 (James Bishop Peabody ed., 1964) (hereinafter HoLMES-EINSTEIN CORRESPONDENCE). The time advantage created by the Judges' Bill may thus be theorized as the marginal difference between these two different levels of scrutiny added to the effort it would have taken to craft and publish opinions in cases not accepted by certiorari.

235. Judiciary Act of 1925, Pub. L. No. 68-415, 43 Stat. 936 (1925). The legislative history of the statute is well told in Hartnett, supra note 225.

236. Van Devanter was the chief draftsman of the Act. He explained the origins of the Act to the General Counsel of the Northern Pacific Railway Co.:

I want to say to you personally that the bill was written throughout in the court and every amendment put on it was written in the court. The preparation of the bill was pretty well under way before I got particularly interested. Experience has taught me that the subject was complicated and involved and that whatever was done should be done according to some real plan. Again, while I was reluctant to see the court take the matter up, I thought if it did it should do well whatever it did. This resulted in my being drawn into the work. I gave it a great deal of attention and if there be faults in it they are attributable to me more than to any one else; although the judgment reflected in the bill was the composite judgment of all the members of the court rather than the judgment of any individual member.

It is known and is recognized in the hearings and in Congress that the bill was prepared in the court; but I believe it better that this should not be dwelt on. At all events I prefer not to be given any credit for what was done. 
Letter from WVD to Charles W. Bunn (Feb. 27, 1925) (Van Devanter papers); Letter from WVD to George B. Rose (Mar. 9, 1925) (Van Devanter papers) ("A committee of three was selected and it fell to me to do the drafting. . . . About that time the personnel of the Court underwent some changes. Justices Day, Pitney and Clarke all approved the bill; Justices Sutherland, Butler and Sanford came on the Court after the bill was prepared and approved.").

In 1927, Felix Frankfurter wrote Taft asking him to clarify the origins of the Act for Frankfurter's forthcoming article in the Harvard Law Review, FF to WHT (Feb. 15, 1927) (Taft papers), and Taft turned to Van Devanter for assistance in responding:

My recollection is that when I came into the Court, Day was a member of the committee looking to the preparation of further legislation - I mean legislation in addition to the Acts of 1915 and 1916 - to relieve the Court and increase its certiorari jurisdiction and decrease its mandatory jurisdiction, and that I added you to the committee with Day, and later McReynolds, and became myself a member of the committee; that we acted on the suggestion of the Senate Judiciary Committee that we prepare a bill, and my recollection is that I went before the Senate Committee and invited their attention to the matter, and then agreed, with their consent - indeed with their suggestion - that I would induce the three members of the Committee - yourself, McReynolds and Sutherland, to appear before them; that we prepared the bill and took perhaps a year or more to work it out and published two statements in respect to it ....

Letter from WHT to WVD (Feb. 21, 1927) (Van Devanter papers) (referring to the 1915 Act at Pub L. No. 63-241, 38 Stat. 803 (Jan. 28, 1915), which involved technical amendments to the Court's mandatory and discretionary jurisdiction that among other things prescribed that all bankruptcy cases coming from federal courts of appeal would have to proceed through writs of certiorari). Taft's memory is consistent with his 1922 testimony to Congress:

The bill has been the subject of very long discussion in the court itself. Before I came into the court a committee had been appointed for its preparation, consisting of Justice Day, Justice McReynolds, and I suppose, ex officio, the Chief Justice. It was taken up again and a very careful and very much extended examination of it made by the committee, to which Justice Van Devanter was added. I suppose we have spent two or three months in its preparation.

Jurisdiction of Circuit Courts of Appeals and United States Supreme Court, Hearing on H.R. 10479 Before the H. Comm. on the Judiciary, 67th Cong. 2d Sess. (Mar. 30, 1922), at 1 (statement of Hon. William Howard Taft); Hearing on H.R. 8206, at 28 (statement of Chief Justice William Howard Taft) ("[W]hen I came into the court, I found Mr. Justice Day at the head of a committee looking to the framing of a bill which looks to the betterment of conditions with respect to the jurisdiction of the courts."). It is also consistent with a letter that Taft sent to the Chair of the Senate Judiciary Committee in 1924: "I think it ought to be emphasized, too, that this matter of legislation to enable the Supreme Court to reduce the business before it, by eliminating unimportant cases, had been referred to a committee, and was under consideration, before I came on the Court." Letter from WHT to Albert Cummins, Senator, U.S. Senate (Jan. 31, 1924) (Taft papers). In 1924, Taft sought to deemphasize his connection to the bill because "there are a number who object to any activity on my part in matters of legislation." Id. 
Van Devanter, however, was certain that Taft's memory was incorrect. Van Devanter replied to Taft in 1927:

No committee having anything to do with legislation was appointed during Chief Justice White's incumbency. He was unalterably opposed to any action along that line by the Court or even by its members. I drafted the act of 1915 and submitted it to him. He approved it but particularly requested that it be turned over to a legislator who would make it his own and in no way connect the Court or any member of the Court with it. Justice McReynolds drafted the act of 1916 and submitted it to Justice Day and myself, some changes were made and it was introduced and passed during a summer recess. When Chief Justice White returned in the fall he was much disappointed at what had been done - so much so that he never became reconciled to that act. This is only inside Court history.

It was at the suggestion of Senator Cummins and some others that you appointed a committee to assist in drafting what subsequently became the Act of 1925. You probably would not have appointed the committee but for the request of Senator Cummins who was Chairman of the Senate Judiciary Committee. You designated Justice Day, myself and Justice McReynolds as the committee, but we insisted that you should also be a member and you assented. Justice Day retired from the Court and the remaining members of the committee continued to act until the bill was passed. Justice Sutherland, by reason of his legislative experience, assisted in presenting the matter but was not a member of the committee. I think it well that we should not overlook the fact that it was at the request of Senator Cummins and others that the Court assisted in preparing the last act. According to tradition the Court always has refrained from connecting itself with legislative work.

Letter from WVD to WHT (May 11, 1927) (Van Devanter papers). The actual origins of the bill are therefore puzzling.

We know that Taft wrote to Senator Cummins on November 25, 1921, commenting on Senate Bill 1831, which would ultimately become Pub. L. No. 67144, 42 Stat. 366 (Feb. 17, 1922), and which would increase the mandatory jurisdiction of the Court in cases involving state construction of contracts. See Letter from WHT to Albert B. Cummins (Nov. 25, 1921) (Taft papers). The Court thought the legislation "unnecessary," Taft remarked. Letter from WHT to Albert B. Cummins (Dec. 1, 1921) (Taft papers). In the course of discussing the bill, however, Taft stressed:

We are preparing a bill which we hope to bring before your committee, to reduce the obligatory jurisdiction of the Supreme Court in cases from the District of Columbia and in a good many instances where a direct review by the Supreme Court is given quite out of keeping with the present system of certiorari, and if this amendment which is proposed in S. 1831 should be adopted, it ought to be incorporated in that bill. I would like to discuss the matter with you. The bill to which I refer is one which has been under consideration by the Supreme Court for some time and which they wish me to go before the committee and present at the request of the Supreme Court.

Letter from WHT to Albert B. Cummins (Nov. 25, 1921) (Taft papers). Taft's letter makes the bill sound far more modest than what the Judges' bill would eventually become. On December 4, Taft again mentioned the bill, this time to the Solicitor General. Taft spoke as though Van Devanter were not involved in its drafting: 
The court has under consideration a bill for the revision of the laws as to proceedings of review in the Supreme Court. A committee consisting of Justice Day and Justice McReynolds have had the matter under advisement for a good many months. We considered it in conference and then made quite a number of changes in the original draft, and then they turned the matter over to me to embody the changes and addition.

I inclose [sic] a copy of a letter which I sent to my colleagues before the conference, for your understanding of the features we have in mind. I wish that you would read the matter over and then submit it to someone in your office who is familiar with the jurisdiction of the Supreme Court .... Letter from WHT to James M. Beck, U.S. Solicitor Gen. (Dec. 4, 1921) (Taft papers). By January, however, Van Devanter could write to Walter H. Sanborn claiming primary responsibility for drafting the bill:

Here is a printed draft of a proposed bill revising the statutes respecting the jurisdiction of the Supreme Court and the Circuit Courts of Appeals and prescribing the mode of obtaining a review, etc. I drafted it, and it represents the composite opinion of the Chief Justice, Justices Day and McReynolds and myself, and was today laid before the other members of the Court. It has not been given any other circulation. We are not and do not intend to be engaged in legislative work, but there is a very pressing need for something along this line, and we have been asked to formulate something which others who are engaged in legislative work may take hold of and pass, if they can, without getting things more confused or more complicated than they are now.

Letter from WVD to Walter H. Sanborn, Judge, U.S. Eighth Cir. (Jan. 7, 1922) (Van Devanter papers); Letter from WHT to Albert B. Cummins (Mar. 11, 1922) (Taft papers) ("I enclose herewith a resume of the jurisdiction bill which I sent you some time ago. Shortly afterwards I sent you a very long detailed explanation of each section, with citations and references. This is for use as a report, if you approve it. I have prepared it with the assistance and criticism of my fellow members of the Committee of the Court, Mr. Justice Day, Mr. Justice Van Devanter and Mr. Justice McReynolds."). Apparently, Van Devanter had taken over drafting the bill after its initial review by the Court's conference in December.

At about that time, the ABA Committee on Jurisprudence and Law Reform, chaired by Taft's brother Henry, was advocating that Congress cure the crisis in the Court's docket by increasing the number of Justices on the Court. See Hartnett, supra note 225, at 1668-69; Letter from WHT to Henry W. Taft (Apr. 6, 1922) (Taft papers) ("The Court are all of them very much opposed to increasing the number of the Court. It would greatly inconvenience us. It would impair the uniformity of decision to have less than the whole Court sit for every case. I hope nothing will be done to give us a town meeting. Consider the danger of setting a precedent to a Demagouge [sic] Democratic Administration.”); Letter from Henry W. Taft to WHT (Apr. 10, 1922) (Taft papers). Solicitor General Beck evidently agreed with the ABA approach. See Letter from James M. Beck to WHT (Dec. 16, 1921) (Taft papers). Taft did his best to squelch the idea, writing Beck, "I have your letter of December 16th, but as we have talked over the matter since, it perhaps is not necessary for me to answer it. I hope you will examine with some care the bill that we are taking a good deal of time to prepare in the court, with a view of helping us when the time comes for its introduction. We are all convinced that the only way to help the situation is to enable 
What Taft called "our great Supreme Court bill" 237 created an entirely "new dispensation" 238 for Court by establishing "drastic limitations upon" 239 its mandatory jurisdiction. It was immediately recognized that the Act "revolutionizes the appellate jurisdiction of the Supreme Court of the United States" 240 by empowering the Court to use the discretionary writ of certiorari to select a large proportion of its own cases. ${ }^{241}$ As Taft wrote his son, the Court could now "pick

us to reduce our jurisdiction by cutting off more writs of error and the exercise of the writ of certiorari." Letter from WHT to James M. Beck (Dec. 18, 1921) (Taft papers).

Although Beck evidently refused to give up the idea of increasing the number of Justices, see Letter from James M. Beck to WVD (Feb. 9, 1922) (Van Devanter papers); Letter from WHT to WVD (Feb. 4, 1922) (Taft papers), he did eventually testify in favor of the Bill. Jurisdiction of Circuit Courts of Appeals and United States Supreme Court, Hearing on H.R. 10479 Before the H. Comm. on the Judiciary, 67th Cong. 2d Sess. (Apr. 27, 1922), at 17 (statement of Honorable James M Beck, Solicitor General); see Hartnett, supra note 225, at 1669. During that period, Holmes wrote Frankfurter that although "I am not the man to give advice as to cutting down the jurisdiction, ... I cannot put too strongly my conviction that the increase of number would be a fatal mistake and I am so near the end of my work that I believe my judgment is free from personal bias if that should be suspected . . . I should be surprised if all the justices did not agree." Letter from OWH to FF (Sept. 9, 1921), in Holmes \& Frankfurter: Their CORRESPONDENCE, 1912-1934 126 (Robert M. Mennel \& Christine L. Compston eds., 1996).

237. Letter from WHT to Mrs. Frederick J. Manning (Feb. 15, 1925) (Taft papers). As Taft wrote to the editor of the American Bar Association Journal, he regarded the Act as "a great step in the history of the Court." Letter from WHT to Edgar Bronson Tolman (Feb. 25, 1925) (Taft papers); see Letter from WHT to Mrs. Frederick J. Manning (Feb. 22, 1925) (Taft papers); Appellate Procedure of U.S. Supreme Court and Circuit Court of Appeals, 11 A.B.A. J. 145 (Mar. 1925) (the Act is "a great step in the history of the United States Supreme Court"). One advantage of the Act on which Taft always insisted was that "the jurisdiction of the Supreme Court is defined in a great many statutes and special acts, and it has really become almost a trap to catch the unwary." It was necessary, therefore, "to simplify the statement of the jurisdiction of the Supreme Court and have it embraced in one statute." Taft, Three Needed Steps of Progress, supra note 137, at 35. See, e.g., Letter from WHT to A. Owsley Stanley, Senator, U.S. Senate (Dec. 5, 1924) (Taft papers) ("For two years our Court has been very anxious to secure the passage of a bill to give us greater power of certiorari so as to reduce the number of cases which come to us, to simplify the statutes which now contain the procedure of appeal to us which are very complicated and form a trap for the lawyers ...").

238. Felix Frankfurter \& James M. Landis, The Supreme Court Under the Judiciary Act of 1925, 42 HARV. L. REV. 1, 1 (1928).

239. Id.

240. Charles W. Bunn, The New Appellate Jurisdiction in Federal Courts, 9 MinN. L. REV. 309, 309 (1925).

241. For a good description of the complicated changes created by the Act in the Court's jurisdiction, see Taft, The Jurisdiction of the Supreme Court, supra note 225, at 2, 4-9. The Act retained mandatory jurisdiction for portions of the Court's 
and choose most of the cases that we shall hear." ${ }^{242}$ The Act, which was "the most sweeping alteration of the Supreme Court's role ever passed in American history," ${ }^{243}$ directly embodied Taft's vision of the Court as an institution whose function is "not the remedying of a particular litigant's wrong, but the consideration of cases whose decision involves principles, the application of which are of wide public or governmental interest, and which should be authoritatively declared by the final court." 244

In July 1925, the Court amended its rules to indicate the kinds of cases that would possess sufficient national importance to warrant the Court's attention:

A review on writ of certiorari is not a matter of right, but of sound judicial discretion, and will be granted only where there are special and important reasons therefor. The following, while neither controlling nor fully measuring the court's discretion, indicate the character of reasons which will be considered:

(a) Where a state court has decided a federal question of substance not theretofore determined by this court, or has decided it in a way probably not in accord with applicable decisions of this court.

(b) Where a circuit court of appeals has rendered a decision in conflict with the decision of another circuit court of a appeals on the same matter; or has decided an important question of local law in a way probably

docket. With respect to federal Courts of Appeals, mandatory jurisdiction attached in what Taft called "a narrow class of cases in which the validity of a state statute is questioned as violating the Constitution or a treaty or statute of the United States, and the decision of the lower court is against its validity." Id. at 5. In such cases, a litigant faced the choice of having the Court exercise mandatory jurisdiction by a writ of error or appeal, but the jurisdiction of the Court would be limited to the Federal question raised, or instead having the Court consider the whole case by applying for a writ of certiorari. With respect to state courts, mandatory jurisdiction attached whenever a state court of last resort decided a case involving "the validity under the Federal Constitution of a treaty or statute of the United States . . . and the decision is against its validity," or whenever "the validity of a statute of a state under the Federal Constitution, treaty or law is questioned and the decision is in favor of its validity." $I d$. Mandatory jurisdiction also attached to certain criminal decisions by federal district courts, as well as to certain decisions by three judge district courts. See id. at 5-6.

242. Letter from WHT to Robert A. Taft (Feb. 8, 1925) (Taft papers).

243. Jonathan Sternberg, Deciding Not to Decide: The Judiciary Act of 1925 and the Discretionary Court, 33 J. SuP. CT. HisT. 1, 14 (2008).

244. Id. at 2. "The real work which the Supreme Court has to do is for the public at large," Taft had told the New York County Bar Association, "as distinguished from the particular litigants before it. ... Its main purpose is to lay down important principles of law and thus to help the public at large to a knowledge of their rights and duties and to make the law clearer." William H. Taft, Address to the New York County Bar Association (Feb. 18, 1922) (Taft papers). 
in conflict with applicable local decisions; or has decided an important question of general law in a way probably untenable or in conflict with the weight of authority; or has decided an important question of federal law which has not been, but should be, settled by this court; or has decided a federal question in a way probably in conflict with applicable decisions of this court; or has so far departed from the accepted and usual course of judicial proceedings, or so far sanctioned such a departure by a lower court, as to call for an exercise of this court's power of supervision. ${ }^{245}$

245. Revised Rule 35, 266 U.S. 645, 681 (1925). The revised rule was wholly new. Compare id., with Rule 37, Rules of the Supreme Court of the United States (1918). But see John E. Thropp's Sons Co. v. Seiberling, 264 U.S. 320, 321 (1924) (deciding a patent infringement case because of a conflict of law between the Third and Sixth Circuit Courts); Keller v. Adams-Campbell Co., 264 U.S. 314, 319-20 (1924) ("Such an ordinary patent case, with the usual issues of invention, breadth of claims, and noninfringement, this court will not bring here by certiorari, unless it be necessary to reconcile decisions of Circuit Courts of Appeal on the same patent. We therefore find ourselves mistaken in assuming that an important issue of general patent law . . . is here involved. The result is that an order must be entered dismissing the writ of certiorari as improvidently granted ...."); Layne \& Bowler Corp. v. W. Wells Works, 261 U.S. 387, 392-93 (1923) (" $[\mathrm{I}] \mathrm{t}$ is very important that we be consistent in not granting the writ of certiorari except in cases involving principles the settlement of which is of importance to the public, as distinguished from that of the parties, and in cases where there is a real and embarrassing conflict of opinion and authority between the Circuit Courts of Appeals. The present case certainly comes under neither head."); Magnum Import Co. v. Coty, 262 U.S. 159, 163 (1923) ("The jurisdiction to bring up cases by certiorari from the Circuit Courts of Appeals was given for two purposes, first to secure uniformity of decision between those courts in the nine circuits, and second, to bring up cases involving questions of importance which it is in the public interest to have decided by this court of last resort. The jurisdiction was not conferred upon this court merely to give the defeated party in the Circuit Court of Appeals another hearing.").

The new Rule was composed by Van Devanter. Letter from WVD to JHC (June 12, 1925) (Van Devanter papers). Taft wrote Van Devanter in June generously acknowledging that "[w]e are all indebted to you, as the country should be, for clearing away the spider webs which have been permitted to persist in our forms and procedure, not really because they come from Marshall's day but because members of the court have been too lazy or too little interested to make the needed changes." Letter from WHT to WVD (June 19, 1925) (Taft papers). Oddly, Taft had written Van Devanter in 1922 that "I have no sympathy with the proposition that the Court ought to define the rules which shall govern it in the issue of the writs of certiorari." Letter from WHT to WVD (Feb. 2, 1922) (Taft papers). Van Devanter's formulation of the rule has remained remarkably stable over the ensuing ninety-two years. Compare Revised Rule 35, 266 U.S. 645, 681 (1925) with SUP. CT. R. 10 (2017). No doubt as a result of Erie Railroad Co. v. Tompkins, 304 U.S. 64 (1938), the modern Supreme Court rule focuses on federal law and removes references to local and "general" law, the importance of which in Circuit Courts of Appeals decisions was likely one reason for Brandeis's refusal to endorse the Judges' Bill. See supra note 233; Black \& White Taxicab \& Transfer Co. v. Brown \& Yellow Taxicab \& Transfer Co., 276 U.S. 518, 
Although the Rule retained traces of the traditional conception of the Court as a final tribunal designed to correct manifest errors by subordinate institutions, ${ }^{246}$ its major thrust was to recast the Court as the national supervisor of the orderly development of federal law..$^{247}$ This was Taft's point all along, and its profound implications were apparent to contemporaries.

The specific rights of particular parties are no longer the essence of the controversies before the Supreme Court. They are mere vehicles whereby the Constitution and the laws of the United States are interpreted, the means whereby the general principles of law are defined, and whereby the rules and conceptions of federal law are made uniform throughout the country. In this respect one might well say that the Supreme Court is abandoning its character as a court of last resort, and assuming the function of a ministry of justice ... . ${ }^{248}$

533 (1928) (Holmes, J., dissenting) (expressing the opinion, before Erie, that there is no general body of law, only the law enacted by the several states).

246. This conception of the Court was eloquently set forth in testimony opposing the Act by Judge Benjamin I. Salinger: "[T] $]$ he great function of the supreme Court is to protect rights given by treaty, the Constitution, or other Federal law. On a proper plea set up, the citizen should be able to obtain the protection of such rightsnot as a matter of grace or of discretion, but as of right - as protection due from the court which is specially charged with insisting upon reverence for Federal law. ... I can not help thinking that every case of violating Federal rights is important in the sense that injury inflicted by the violation should entitle the sufferer, as a matter of right, to have redress in the Supreme Court." Jurisdiction of Circuit Courts of Appeals and United States Supreme Court: Hearing on H.R. 10479 Before the H. Committee on the Judiciary, 67th CoNG. 5 (Apr. 18, 1922) (statement of Hon. Benjamin I. Salinger of Carroll, Iowa). See Limits on Appeals Viewed as a Peril, N.Y. TIMES, Apr. 9, 1922, at 1. Traces of this conception of the Court are apparent in how contemporaries interpreted the meaning of Court's denial of petitions for certiorari. So, for example, in 1925 the Court of Appeals for the Ninth Circuit said: "What effect should be given to the denial of a writ of certiorari by the Supreme Court we are not prepared to say, but it would seem that if the Circuit Court of Appeals misconstrued a federal statute and affirmed the conviction of a person innocent of crime, the Supreme Court would undoubtedly review its decision." Lupipparu v. United States, 5 F.2d 504, 504 (9th Cir. 1925).

247. Taft's anxiety for the Court to adopt this role is apparent. See, e.g., Sun Ship Bldg. Co. v. United States, 271 U.S. 96, 99 (1926) ("Valuable time was taken in hearing these cases. After arguments on behalf of the claimants, we declined to hear the other side because of the correctness of the judgments of the Court of Claims was clear. It is fortunate for all that, under the Act of February 13, 1925, judgments of the Court of Claims entered after May 13, 1925, can only be reviewed here after a showing of merits."). In St. Louis, Kennett \& Southeastern Railroad Co. v. United States, 267 U.S. 346 (1925), a case coming from the Court of Claims, Taft wrote on his return to Brandeis's circulated draft, "I concur. The new jurisdiction bill will rid of such cases as this." (Brandeis papers).

248. Hankin, supra note 215 , at 40. 
Just as the Act of September 14, 1922 had initiated a process that would lead to the creation of a unified federal judicial branch headed by the Chief Justice, so the Act of February 13, 1925 established the Supreme Court as the institutional manager of the system of federal law in both state and federal courts. It radically expanded the Justices's "options to select the issues they would address, and to manage the appropriate time, case, and factual context in which to break new constitutional ground." 249

In the long run, the Act would diminish the Court's ability to draw on its previous legitimacy as a simple dispute settlement mechanism. Instead the Court would throughout the twentieth century be required to search for ways to justify its decisions despite the fact that it was selecting its own cases to serve ends extrinsic to the cases themselves. Like the Act of September 4, 1922, therefore, the Judges' Bill shattered the image of courts as institutions unaffected by such exogenous imperatives. Taft had within a few short years created and centralized judicial power in ways that previously would have been all but inconceivable. 250

The effect of the Judges' Bill on the Court's docket was nothing short of "marvelous." 251 Figures 12 and 13 demonstrate the precipitous decline in the Court's arrears, which was almost certainly due to the operation of the Judges' Bill. By the conclusion of the 1928 Term, "the Court [had] caught up with its work. It has disposed of all the cases it could have acted upon.... In fact, so rapid has been the Court's pace,

249. Stephen C. Halpern \& Kenneth N. Vines, Institutional Disunity: The Judges' Bill and the Role of the U.S. Supreme Court, 30 WESTERN POL. Q. 471, 483 (No. 4) (Dec. 1977).

250. As Senator Walsh remarked, "[t]he House Committee on the Judiciary was told by the Chief Justice that the bill is the work of the Justices of the Supreme Court. If so, it exemplifies that truism, half legal and half political, that a good court always seeks to extend its jurisdiction, and that other maxim, wholly political, so often asserted by Jefferson, that the appetite for power grows as it is gratified." 62 CoNG. REC. 8547 (June 12, 1922).

251. HANKIN \& HANKIN, supra note 2, at 2. "I have no hesitation in saying that the system of certioraris which obtains under the Act of February 13, 1925, works well." Letter from WHT to Harry A. Hollzer, Judge, S.D. Cal. (Sept. 14, 1928) (Taft papers). "Thus far the 1925 act has enabled the Court to gain upon its arrears," Frankfurter and Landis wrote in 1928. Frankfurter \& Landis, supra note 238, at 14. "Not for a hundred years has the Court reached for argument on the regular calendar cases docketed during the term. Last term it achieved this dispatch in its business." Id. Despite Brandeis's initial opposition to the Bill, supra note 233, his biographer Melvin Urofsky writes, "Within a few years, however, he recognized that Taft had been right, as the Court gained control over its docket and eliminated the backlog of cases.” Melvin I. UROFSKY, Louis D. BRANDEIS: A LiFE 585 (2009). 
that its efficiency has become a source of embarrassment to counsel in the preparation of their cases." ${ }^{52}$ To the American Law Institute, Taft chuckled, "I can say with respect to the business of the Court that under the beneficent Act of February 13th, 1925, we have made such progress with business that I think members of the Bar are beginning to be a little embarrassed by the proximity of the Court to them." 253 By the end of the 1929 Term, Van Devanter could claim that "the Court is now more nearly current with its work than it has been at any time in many years. ... [C]ases are now reached for argument within about six months after they are docketed. The members of the Court are all

252. Gregory Hankin \& Charlotte A. Hankin, United States Supreme COURT 1928-1929 2-3 (1929). Holmes wrote that in the absence of the Act "we should have to hear many cases that have no right to our time; as it is we barely keep up with the work. We used to be years behindhand. Now I think all the cases on our docket have been put there within a year." Letter from OWH to Frederick Pollock (Aug. 30, 1929), in 2 Holmes-Pollock CORRESPONDENCE, supra note 69, at 251. Holmes praised the Act as "a wise means that saves much time." Letter from OWH to Lewis Einstein (Sept. 20, 1926), in Holmes-Einstein CoRRESPONDENCE, supra note 234 , at 261 . Holmes did complain, however, about the "steady stream of certioraris [that] seems to fill every crevice of promised leisure." Letter from OWH to Harold Laski (Apr. 17, 1928), in 2 HolMES-LASKI CORRESPONDENCE, supra note 210, at 1045. For Brandeis, the "moral" of the Act was:

U.S.S.C.- venerated throughout the land.

Despite the growth of population, wealth and governmental functions, \& development particularly of federal activities[,] the duties of the Court have, by successive acts passed from time to time throughout a generation, been kept within such narrow limits that the nine men, each with one helper, can do the work as well as can be done by men of their caliber, i.e. the official coat has been cut according to the human cloth.

Congress, Executive Depts., Commissions \& lower federal courts.-All subject to criticism or execration.

Regardless of human limitations, increasing work has been piled upon them at nearly every session. The high incumbents, In many cases, perform in name only. They are administrators, without time to know what they are doing or to think how to do it. They are human machines.

Letter from LDB to FF (Feb. 6, 1925), in BRANDEIS FRANKFURTER CORRESPONDENCE, supra note 41, at 191-92.

253. Chief Justice Taft's Address, 15 A.B.A. J. 332 (1929). At this point the article indicates "Laughter." Id. In Taft's draft of his remarks, his next sentence reads: "We are stepping on their heels." William Howard Taft, Speech before the ALI (May 1929) (Taft papers). 
agreed that the new system is a great improvement over the old and that it works to the real advantage of litigants." 254

Although the statute had actually been drafted by Van Devanter, ${ }^{255}$ everyone understood that the impetus for the Act and its passage had come from Taft himself. 256 "His political associations I suppose made it easier to get passed a bill remodeling our jurisdiction ... that was very important and I think will work well," Holmes wrote his friend Harold Laski. ${ }^{257}$ As a former President, Taft was at ease in the political circles of Washington power. ${ }^{258} \mathrm{He}$ effectively persuaded

254. Willis Van Devanter, The Supreme Court of the United States, 5 IND. L.J. 553, 560 (1930). By contrast, during the 1924 Term, immediately prior to the enactment of the Bill, the Court was according to Taft "a year and three months behind" in its docket. Letter from WHT to Marcus Kavanagh (Dec. 14, 1925) (Taft papers). By the conclusion of the1929 Term, the Court had "disposed of all the cases which had been argued. This occurred for the first time in about thirty five years." HANKIN \& HANKIN, supra note 2, at 29. Taft's ambition for the Act, as he stated to Congress, was that "[w]e ought to be able to dispose of every case we have during the term, that is between October and June." Jurisdiction of Circuit Courts of Appeals and of the Supreme Court of the United States: Hearing on H.R. 8206 Before the H. Comm. on the Judiciary, 68th Cong. 28 (1924) (statement of William H. Taft, Chief Justice); Vinson Tells A.B.A. of Supreme Court Work; Opinion on Dissents, 20 OKLA. B.J. 1269, 1269 (1949) ("The days before passage of the 1925 Act, when it took eighteen to twenty-four months for the Court to reach a case on its docket, are forgotten, and it is assumed by everyone, as it should be, that the Supreme Court is current in its work. The Court will soon have been operating under its basic jurisdictional statute for a quarter of a century, and experience has eloquently proved the wisdom of its architects.").

255. See supra note 236. Van Devanter's masterful technical drafting of the bill after December 1921 might have been one reason why Taft came so early and so completely to rely on Van Devanter's judgment.

256. Thus when Congress failed to pass the bill in 1922, Taft wrote to the Dean of Indiana Law School:

I had the bills introduced in the last Congress, but they were so hurried in the short session that I did not get an opportunity to go before either committee, and I don't know how much reason I have to hope that the next Congress will act more favorably; but I mean to keep pressing the matter, because that is the only way of getting anything through Congress. Persistence usually wins.

Letter from WHT to Charles M. Hepburn (Apr. 10, 1923) (Taft papers).

257. Letter from OWH to Harold Laski (Nov. 13, 1925) in Holmes-LASKI CORRESPONDENCE, supra note 45, at 797.

258. A.H. Ulm, Behind Scenes of the Supreme Court: Its Traditions Have Remained Steadfast in Face of Many Changes in Personnel, N.Y. TIMES, Jan. 18, 1925, at SM5 ("Justice Taft, it is said, does not hesitate to 'talk politics' now, though not publicly. He confers with the President and with Cabinet members frequently, and it is stated that when they call on him he freely gives them the benefit of his political knowledge."). 
Coolidge to recommend passage of the Act to Congress. ${ }^{259} \mathrm{He}$ relentlessly and personally lobbied legislators to ensure its passage..$^{260}$ He rallied the American Bar Association to swing its considerable weight in support of the Bill. ${ }^{261}$

\section{The Changing Role of ChIEF Justice}

All this represented a major transformation of the role of Chief Justice. It was a change that made those around Taft feel somewhat uncomfortable. Consider, for example, the testimony of Justices Sutherland, Van Devanter, and McReynolds in support of the Judges' Bill before the House Judiciary Committee. When Sutherland was about to speak, Representative Andrew Jackson Montague of Virginia

259. In his 1924 State of the Union, Coolidge recommended "immediate favorable consideration" of the Bill on the ground that " $[\mathrm{t}]$ he docket of the Supreme Court is becoming congested. . . . Justice long delayed is justice refused. Unless the court be given power by preliminary and summary consideration to determine the importance of cases, and by disposing of those which are not of public moment reserve its time for the more extended consideration of the remainder, the congestion of the docket is likely to increase." Message from the President, 66 CONG. REC. 54 (Dec. 3, 1924). Taft had written his son that "[w]e are going to make an effort at this session of Congress to try and get our Supreme Court bill through. I don't know whether we can do it, but the only way is to keep trying and after a while we may induce some action. I asked the President to help us and he told me to write him something, which I did. I am afraid he won't put in all have written, but I can get him started, it will perhaps attract the support of the party members." Letter from WHT to Robert A. Taft (Nov. 30, 1924) (Taft papers). Taft had also induced Coolidge to support the bill in 1923. See Message from the President, 65 ConG. REC. 98 (Dec. 6, 1923); Letter from WHT to Robert A. Taft (Dec. 2, 1923) (Taft papers) ("I wrote a part of his Message - that is I wrote a passage to be embodied in his Message, which he has cut down some, but in effect he has put in all of my recommendations.").

260. See Letter from WHT to Frank B. Kellogg, Senator, U.S. Senate (May 10, 1922) (Taft papers); Letter from WHT to Joseph Walsh, Congressman, U.S. (June 5, 1922) (Taft papers); Letter from WHT to Horace D. Taft (Feb. 1, 1923) (Taft papers) ("I don't think the present Congress will do anything with the bills which I had introduced. The lethargy and inert opposition to change are most discouraging, but I mean to keep it up, because that is the way to get things through Congress."); Letter from WHT to A. Owsley Stanley, Senator, U.S. Senate (Dec. 5, 1924) (Taft papers); Letter from WHT to Charles P. Taft II (Dec. 14, 1924) (Taft papers) ("I have been writing letters to a lot of Democrats to interest them in the Supreme Court bill. ... Unless I can get from the Rules Committee of the House a special order giving us a few hours to consider the bill, I am afraid it will fail, but I am hoping I may be able to do that."); Letter from WHT to Robert A. Taft (Taft papers) ("I am pressing the Supreme Court procedure bill in the House and in the Senate."); Letter from WHT to Charles P. Taft II (Feb. 3, 1925) (Taft papers) ("I have been spending two days at the Capitol to get through a Supreme Court bill.").

261. See Hartnett, supra note 225, at 1673-74. 
interrupted to ask whether "you wish to appear as the authors of this bil [sic]?"262 Before Sutherland could respond, Van Devanter intervened:

May I state and let go into the record what occurred? The matter in some
way came to the attention of the Judiciary Committee of the Senate. The
chairman of that committee communicated with the Chief Justice and
requested that the court, members of the court out of their experience,
should prepare a bill which would meet the situation. The court hesitated at
first, but as a result of further conferences between the Chief Justice and the
chairman of the Judiciary Committee of the Senate, the court appointed a
committee which drafted a bill, and submitted it to the full court... In the
sense of volunteering, the court did not prepare the bill, but the bill was
prepared in the court as a result of the invitation that came in the way I have
indicated.

George Graham of Pennsylvania, the Chairman of the Committee, then commented that he was "glad" that it had been made "clear that the Supreme Court has not prepared the bill, thrusting it upon our attention as to what should be done, but that it has been prepared at the request of the Judiciary Committee of the Senate." ${ }^{264}$ Representative Ira Hersey of Maine noted that in the Senate report it was asserted that the bill had been prepared by members of the Supreme Court "at the suggestion of the American Bar Association." 265

In point of fact, the ABA had not suggested to the Court that the Bill be drafted; in 1922, the ABA had instead sought to reduce the Court's workload by increasing the number of Justices. ${ }^{266}$ It was rather Taft who had pushed the ABA to support the Bill. But the confusion is instructive, for it manifests the unease aroused by Supreme Court Justices actually initiating legislation. That is why Van Devanter so swiftly intervened to emphasize that the impetus for the bill had come

262. Jurisdiction of Circuit Courts of Appeals and of the Supreme Court of the United States: Hearing on H.R. 8206 Before the H. Comm. on the Judiciary, 68th Cong. 23 (1924). For a discussion, see Hartnett, supra note 225, at 1687-89.

263. Jurisdiction of Circuit Courts of Appeals and of the Supreme Court of the United States: Hearing on H.R. 8206 Before the H. Comm. on the Judiciary, 68th Cong. 23 (1924).

264. Id. On Graham's sensitivity to judicial encroachments on the legislative prerogatives, see supra note 175.

265. Hearing Before the Comm. on the Judiciary of the H.R. on H.R. 8206, 68th Cong. 23; S. REP. No. 68-362, at 1 (1924) ("The bill was prepared by a committee of the members of the Supreme Court after a long and careful study of the subject, at the suggestion of the American Bar Association, and has the approval of every member of that court.").

266. See supra note 236 and accompanying text. 
from Albert Cummins, the Chair of the Senate Judiciary Committee. ${ }^{267}$ But despite the persistent equivocations in both Taft's and Van Devanter's accounts, ${ }^{268}$ Taft had almost certainly pressed the legislation on Cummins, rather than the reverse. ${ }^{269}$ Throughout the decade, Taft routinely sought to initiate and lobby for legislation that he regarded as constructive. "I have thought that it was part of my duty," he wrote the Chief Judge of New York, "to suggest needed reforms, and to become rather active in pressing them before the Judiciary Committees." ${ }^{270}$

Taft's aggressive promotion of reform represented a radically new conception of the Chief Justiceship. Chief Justice Edward Douglass White had been "unalterably opposed" to "the Court or even ... its members" involving themselves in the legislative process. ${ }^{271}$ White represented the traditional view, which Taft fully understood, that a "judge should avoid extra-judicial activities . . . because they may put him in an attitude actually or seemingly inconsistent with absolute impartiality in the discharge of his judicial duties." ${ }^{272}$ But Taft conceived the Chief Justiceship as closer in spirit and responsibility to the position of the English Lord Chancellor, an executive official whose portfolio included the administration of justice, than to any previous American conception of a federal judge. ${ }^{273}$ Taft construed "the duties of the position to include administrative reform affecting

267. But see Taft, supra note 256. Van Devanter would later express this same pointed emphasis on Cummins's involvement in his letter to Taft on May 11, 1927. See supra note 236.

268. See supra note 236 and accompanying text.

269. See id.; Hartnett, supra note 225, at 1662-63. Felix Frankfurter and James M. Landis wrote in 1927 that Taft, "unlike some of his predecessors, . . . deemed it the prerogative and even the duty of his office to take the lead in promoting judicial reform and to wait neither upon legislative initiation in Congress nor upon professional opinion." Felix Frankfurter \& James M. Landis, Business of the Supreme Court of the United States-A Study in the Federal Judicial System, VII: The Judiciary Act of 1925, 40 HARV. L. REV. 834, 838-39 (1927).

270. Letter from WHT to Frank H. Hiscock, Chief Judge, N.Y. Court of Appeals (Apr. 12, 1922) (Taft papers).

271. Letter from WVD to WHT (May 11, 1927) (Van Devanter papers); see supra note 236 and accompanying text. Chief Justice Fuller, by contrast, had offered opinions about pending legislation concerning the jurisdiction of the Court. See, e.g., Letter from Chief Justice Melville W. Fuller, 23 CoNG. REC. 3285-86 (Apr. 14, 1892).

272. William Howard Taft, To the Readers of The Tribune, MinNEAPOLIS MORNING TRIB., July 18, 1921, at 6.

273. The analogy was quite explicit in Taft's mind. See infra notes 288, 292 and accompanying text. 
the entire federal judicial system and also efforts to obtain needed legislation." ${ }^{274}$

From the very beginning, Taft acknowledged that "I don't think the former Chief Justice had so much to do in the matter of legislation as I have. I don't object to it, because I think Chief Justices ought to take part in that, but it consumes time and energy." 275 Taft considered it "part of my duty, as [the head] of the Federal Judiciary system, to suggest needed reforms, and to become rather active in pressing them before" Congress. ${ }^{276}$ The difficulty, however, was that these efforts could rather rapidly bring his office "into a field of heated discussion." ${ }^{277}$ After advocating for the Act of September 14, 1922, for example, Taft was the subject of a harsh personal attack in the Senate by George Norris:

When these judges come to Washington at the expense of the taxpayers, what will they do? They will meet with the Chief Justice. They will be dined every evening somewhere. They will be run to death with social activities. They will be killed with social favoritisms before they get down to business. That is especially true in respect to the genial chief justice we have, who dines out somewhere every night. I would like to pause right here to say ... that I do not believe there is any man who can stick his legs under the tables of the idle rich every night and be fit the next day to sit in judgment upon those who toil. ${ }^{278}$

Taft sought to shrug off these attacks. "If I can get legislation through, I am willing to subject myself to this personal unpleasantness, though of course I would deprecate its affecting the influence of the Court." 279 "I am determined to push a movement for the betterment of the procedure in the Federal courts. I suppose I weigh down such reform by my advocacy of it, in arousing the opposition of certain

274. A Federal Commission on Judicature, 6 J. Am. JudicAture SoC'y 47, 47 (1922).

275. Letter from WHT to Horace D. Taft (Mar. 30, 1922) (Taft papers).

276. Letter from WHT to Frank H. Hiscock, Chief Judge, N.Y. Court of Appeals (Apr. 12, 1922) (Taft papers).

277. Id.

278. 62 Cong. ReC. 5113-14 (Apr. 6, 1922) (statement of Sen. Norris).

279. Letter from WHT to Frank H. Hiscock, Chief Judge, N.Y. Court of Appeals (Apr. 12, 1922) (Taft papers). "But my impression, from a considerable experience in matters of this sort, is that even with the publicity that the position of a Senator secures, such attacks are ephemeral in their effect, and are only remembered by the comparative few who really sympathize with the Senator in his extreme view. It is wonderful what the inevitable and ever-pressing course of events will efface from public memory. It is too bad, however, that we have such blatherskites . . . as Norris ...." Id. 
elements, especially in the Senate, but I don't know why that should prevent my initiating matters when nobody is likely to do so." 280

We know, however, that despite his brave front, personal attacks like these hurt Taft personally. As he wrote his brother about a different attack: "And so I suffer. I lose sleep at night worrying over it. I think I have inherited Mother's disposition to worry. So all I can do is to have you pray for me, because the 'prayers of the righteous avail much'. If you see my name scored as a disgrace to the Bench and to me and the family, still hold out an anchor of hope for me."281

Whatever his protestations, Taft's reconceptualization of the Chief Justiceship produced role-tensions that he acutely appreciated. He gave up his regular newspaper column when he became Chief Justice, for example, stating:

The degree in which a judge should separate himself from general activities as a citizen and a member of the community is not usually fixed by statutory law but by a due sense of propriety, considering the nature of his office, and by well-established custom. Certainly, in this country at least, a judge should keep out of politics and out of any diversion or avocation which may involve him in politics. It is one of those characteristic queer inconsistencies in the British judicial system, which was the forerunner of our own, that the highest judicial officer in Great Britain, the Lord Chancellor, is often very much in politics and has always been. ${ }^{282}$

After July 1921, however, Taft found that he simply could not contain his "bursting expression" 283 in favor of improving the administration of justice.

Taft sought to reconcile his reform efforts with American norms of judicial disinterest by arguing that "there are some things that a judge may speak of and may discuss in public and not use a judicial opinion for the purpose" and that "law reform" was one such subject. ${ }^{284}$ This was especially true in the context of professional bar associations. "One of the most important extra curriculum things that I have to do as Chief Justice," he said in 1923, is "to organize the Bench and the Bar into a united group in this country dedicated to the

280. Letter from WHT to Horace D. Taft (Apr. 17, 1922) (Taft papers).

281. Letter from WHT to Horace D. Taft (Dec. 12, 1926) (Taft papers).

282. Phila. Pub. Ledger, July 14, 1921, at 1; see Taft, To the Readers of The Tribune, supra note 272, at 6 . For a discussion of Taft's career as a columnist, see James F. Vivian, William Howard TAFT: ColleCted Editorials 1917-1921 (1990).

283. Taft, supra note 244.

284. Id. 
cause of the improvement of judicial process."285 Elihu Root commented to Taft that he was "the first Chief Justice to fully appreciate the dynamics of the Bar as an organization. If a national bar spirit can be created it will have an immense effect upon the administration of justice." ${ }^{286}$

Taft began his program of mobilizing the bar almost immediately upon taking office. On August 30, 1921, he spoke to the Judicial Section of the American Bar Association, seeking support for the Act of September 14, 1922.287 Two days later, he explicitly defended the participation of judges in seeking legislative reform in matters of judicial administration. ${ }^{288}$ Four months later, he spoke to the

285. Letter from WHT to Clarence Kelsey (Aug. 17, 1923) (Taft papers); Letter from WHT to Charles Evans Hughes (Apr. 26, 1926) (Taft papers) ("Bar Associations are formed too often for merely social enjoyment and fraternization, with only a modicum of effort to . . . exert a controlling influence upon the legislative bodies for real reform measures in respect to courts and legal procedure."); Letter from WHT to R.H. Thompson (Sept. 24, 1923) (Taft papers) ("I am strongly in favor of the maintenance of bar associations and the keeping of them in a virile condition to exercise the legitimate influence that members of the bar should have upon the people in the matter of the preservation of our institutions of civil liberty and the maintenance of the supremacy of law through constitutional means. I have made it my function to attend the annual meeting of the American Bar Association for the purpose of keeping in touch with that representative body of American lawyers.").

286. Letter from Elihu Root to WHT (Sept. 9, 1922) (Taft papers).

287. Taft, Adequate Machinery for Judicial Business, supra note 124, at 454.

288. On September 2, 1921, Taft declared to the closing dinner of the ABA annual meeting:

Why should not judges, who have so much to do with the administration of justice, take part in your councils and receive from the deliberations the suggestions so valuable that must come from the consideration of the leading members of the bar? And, on the other hand, why should they not be able to aid you in discussing and recommending measures for improvement of the procedure of the law?

There was a time, possibly, when judges thought that they should keep apart. Of course, there are limitations upon judicial action, but no one who is at all familiar with what are reasonable limitations upon the action of judges can object to their coming into meetings like these and discussing and advancing their views as to improvement in legislative and administrative measures for the dispatch of legal business.

We in this country do not have the great benefit that Parliament has in great Britain in the presence of the responsible law officer of the Government in the House of Commons and the great jurists, especially the Lord Chancellor, in the House of Lords. . . . While we cannot have that exact system, it seems to me that the American Bar Association has taken a great step forward when it is summoning to aid in its councils the judges of this country. Therefore, it gives me pleasure to say that whenever I can I am coming to the meetings of the American Bar Association. And ... I am 
Chicago Bar Association, seeking support for the Judicial Conference statute, as well as for what would become the Judiciary Act of February 13, 1925. ${ }^{289}$

These speeches were criticized on the floor of the United States Senate as "different from those made by any other Chief Justice." 290 Senator William J. Harris of Georgia opined that "the judiciary is going to be injured, and the people will not have the same high respect for it if the Chief Justice and associate justices of the Supreme Court of the United States make speeches in public not in their line of duty as has been done recently." ${ }^{291}$

But Taft was defiant. Invoking English precedents, he shot back three days later in an address to the New York County Bar Association:

I venture to think that there are some things that a judge may speak of and may discuss in public and not use a judicial opinion for the purpose. The subject is that of law reform. From the earliest traditions of the English bench from which we get our customs, the judges of the highest courts of Great Britain have taken an interest in and a part in the formulation of legislation for bettering the administration of justice. They have written and spoken on such subjects with entire freedom and without incurring criticism. You doubtless remember that in Campbell's Lives of the Lord Chancellors and the Chief Justices, a part of the story of each life is work done in law reform. Measures of this sort that are put through in England are usually prepared by the law officers of the government and sometimes by the Lord Chancellor himself. The judges of the Supreme Court have taken an active part in the discussion of the measures as they go through their legislative course. And why should it not be so? With their attention constantly directed toward the workings of the machinery of the

going to discuss those subjects in which I have an interest, and in which I can make a suggestion. If a judge on an occasion like that advances an opinion on a question of law which might subsequently arise in a case before him, he is a pretty poor judge if he cannot ignore the opinion he has already expressed.

Chief Justice William H. Taft, After-Dinner Oratory at Cincinnati (Sept. 21, 1921), in 7 A.B.A. J. 605, 606 (1921).

289. Taft, Three Needed Steps of Progress, supra note 137, at 34.

290. 62 Cong. ReC 2582-83 (Feb. 15, 1922); see Taft's Public Speeches Criticized in the Senate, N.Y. TRIB., Feb. 16, 1922, at 2.

291. 62 CONG. REC 2582-83 (Feb. 15, 1922). Senator Harris also very much objected to Justice Clarke's speech urging cancellation of the foreign war debt. See Justice Clarke Urges Prompt Cancellation of War Debt, CHI. J. CoM., Feb. 9, 1922, at 1; 62 CONG. REC. 2525 (Feb. 14, 1922) ("I have the greatest respect and admiration for Justice Clarke . . . . However, I think that the Justices of the Supreme Court of the United States should keep out of any matters that are political . . . I do not think it is the part of wisdom for a Supreme Court Justice to publicly discuss matters to be decided by Congress.") (statement of Sen. Harris). 
administration of justice, they are at a more advantageous point of observation and if they use their opportunities, are better able to make recommendations with respect to law reform than any other class in the community. ${ }^{292}$

Taft never did retreat from his commitment to advocate for the improvement of the administration of justice. He continued actively to seek legislative reform of judicial procedures for the remainder of his tenure as Chief Justice. ${ }^{293} \mathrm{~A}$ distant echo of his extraordinary example can still be heard when we hear Chief Justices speak today about the need for federal courts and Congress to "work together if feasible solutions are to be found to the practical problems that confront today's federal judiciary." 294

\section{ROLE CONFLICTS IN PROTECTING THE FEDERAL JUDICIARY}

In his initial programmatic statement to the Chicago Bar Association in December 1921, Three Needed Steps of Progress, ${ }^{295}$ Taft had advocated for three major reforms: the Act of September 14, 1922; the Judiciary Act of February 13, 1925; and legislation authorizing the Supreme Court to promulgate rules of procedure that would fuse law and equity. ${ }^{296}$ By the middle of the decade, he had

292. Taft, supra note 244. Taft left no doubt about the target of his remarks:

[I]t is a source of some embarrassment for me to rise here and not to talk to you as I would like to talk to you, free from the fetters of the office which I hold. ... I am struggling to be worthy of the bench of which I am a member. I am struggling to fall into the customs and the requirements of that position. We have been warned in the Senate of the United States what our narrow function is and with due respect to that warning, I am going to confine myself to a written manuscript.

Id. at 1-2. For press coverage of the speech, see Taft Approves Laws to Clear Court Dockets, N.Y. TRIB., Feb. 19, 1922, at 13; Taft Backs Bills to Speed Trials, N.Y. TIMES, Feb. 19, 1922, at 18.

293. Chief Justice Taft Urges Adoption of Rule-making Power, 7 J. AM. JUDICATURE SOC'Y 134, 134 (1923) ("I am especially interested in the matter of procedure, because procedure stands between the abuse of the principles of law and their use for the benefit of mankind. You can have as high and as sound principles of law as possible, but if you have not the procedure by which you can apply them to the ordinary affairs of men, then it does not make any difference what the principles are or how erroneous they may be.").

294. Chief Justice William H. Rehnquist, 1996 Year-End Report on the Federal Judiciary, 29 THIRD BRANCH 1, 6 (1997).

295. Taft, Three Needed Steps of Progress, supra note 137, at 34-36.

296. On Taft's support for giving the Supreme Court rule-making authority in common-law cases, which would effectively fuse law and equity, see Taft, Possible and Needed Reforms, supra note 101, at 604-07. Taft explicitly invoked English 
accomplished the first two of these reforms. But the last, which Taft had been advocating since at least 1914, ${ }^{297}$ would prove elusive.

Although Taft persuaded Coolidge to recommend passage of the reform, ${ }^{298}$ Senator Thomas J. Walsh of Montana, who had fought for Brandeis's confirmation to the Court and against that of Harlan Fiske Stone, was dead set against it. ${ }^{299}$ Walsh was able to prevent Senatorial action on the legislation, ${ }^{300}$ despite the strong support of Taft and the

precedents to justify the reform. See Chief Justice Taft Urges Adoption of Rule-making Power, supra note 293, at 134.

297. See supra note 112 and accompanying text.

298. Message from Calvin Coolidge, President of the United States, 66 Cong. REC. 54 (Dec. 3, 1924) ("It is also desirable that the Supreme Court should have power to improve and reform procedure in suits at law in the Federal courts through the adoption of appropriate rules."). See supra note 259.

299. See Thomas J. Walsh, Senator for Montana, Address to the Senate: Reform of Federal Procedure (Apr. 23, 1926); Thomas J. Walsh, Rule-Making Power on the Law Side of Federal Practice, 13 A.B.A. J. 87 (Feb. 1927); Thomas J. Walsh, Senator Walsh Replies, 12 A.B.A. J. 651-52 (Sept. 1926); Thomas J. Walsh, The Law's Delays and the Remedy, N.Y. TIMES, Jan. 12, 1925, at 14. Taft believed that there would "be no difficulty" in passing the bill "but that Walsh of Montana and Shields of Tennessee are opposed." Letter from WHT to Horace D. Taft (Dec. 7, 1924) (Taft papers). He fumed that "Walsh is one of the most narrow-minded men I know, not a useful legislator, because he never looks for progress. He is always looking for criticism." Id.; see Letter from WHT to LDB (July 25, 1922) (Taft papers) (criticizing Walsh in terms that Taft would later explicitly apply to Brandeis); discussion supra note 233. Walsh was aided in his opposition by the fact that both Brandeis and McReynolds disapproved the legislation. See Letter from WHT to Thomas W. Shelton (Mar. 5, 1928) (Taft papers); Letter from Thomas W. Shelton to WHT (Mar. 3, 1928) (Taft papers); S. REP. No. 70-440 on S. 759, at 1 (1928). Taft had prevented Holmes from also publicly expressing disapproval of the legislation:

Judge Holmes wrote that he was against the whole business because he thinks that procedure would not help when we have such a poor Bar and such a poor Bench. ... I I rather differed with him in the view that because we are behind England in this regard we ought not to do what we can to better the facilities for proper progress. By my remarks to him, I succeed in holding back his letter to Walsh, which I was afraid Walsh might use to the disadvantage of the bill.

Letter from WHT to Harlan Fiske Stone, Justice, U.S. Supreme Court [hereinafter HFS] (May 18, 1926) (Stone papers); see Letter from WHT to Henry W. Taft (May 18, 1926) (Taft papers) (describing phone conversation with Holmes and Taft's argument that "if we were to wait until the leopard changed his spots, and the American people and lawyers and judges became better men, we should never do anything that was progressive and helpful," but also condemning the "very poor" Senate judiciary committee "consisting mostly of radicals and progressives").

300. See, e.g., Report of the Special Committee on Uniform Judicial Procedure, 47 AnNuAl RePORTS A.B.A. 483, 486 (1924) ("The jurisdiction bill . . . was very promptly reported out of the full Judiciary Committee of the Senate . . . but there was personal influence enough on the part of one or two Senators to prevent a 
ABA. ${ }^{301}$ It was not until after Walsh's sudden demise in 1933 (when he was FDR's Attorney General designate) that the Rules Enabling Act could finally be passed. ${ }^{302}$ But by then Taft had long since passed from the scene.

The defeat of legislation simplifying federal procedure rankled Taft, not merely because he thought it made litigation more expensive, but also because he was strongly drawn to judicial equitable authority, as distinct from the reliance on juries characteristic of the common law. As a Justice, Taft did his best to expand equitable jurisdiction that would bypass the need for juries. ${ }^{303}$ Taft believed that juries "greatly

report upon the procedure bill (S. 2061), although a majority favored it. There ought to be some way of overcoming a personal legislative influence of a character that can defeat a majority, the public will and the administration of justice by smothering bills in committee.").

301. Edward A. Purcell, JR., Brandeis AND the Progressive Constitution 28-33 (2000). Taft attributed Walsh's opposition to the fact that he was "a very great enemy of the Federal Courts," Letter from WHT to Henry W. Taft (July 4, 1924) (Taft papers), a mere plaintiffs' damages lawyer who "lost cases in the Federal trial courts in seeking to impose verdicts on railroads and other corporations with thin cases." Letter from WHT to Charles P. Taft II (Apr. 1, 1928) (Taft papers). George Scott Graham of Pennsylvania, the Chairman of the House Judiciary Committee from 1923 until the end of the decade, was also firmly opposed to the legislation. See, e.g., Letter from Thomas W. Shelton to WHT (Jan. 24, 1925) (Taft papers).

302. Rules Enabling Act, Pub. L. No. 73-415, 48 Stat. 1064 (1934) (codified as amended at 28 U.S.C. $\$ 2072$ (1990)). See generally Stephen N. Subrin, How Equity Conquered Common Law: The Federal Rules of Civil Procedure in Historical Perspective, 135 U. PA. L. REV. 909 (1987).

303. See, e.g., Liberty Oil Co. v. Condon Nat'l Bank, 260 U.S. 235-36 (1922). Liberty Oil Co. became a major building block in the argument that the Supreme Court could constitutionally create rules of procedure that combined law and equity. See Charles T. McCormick, The Fusion of Law and Equity in United States Courts, 6 N.C. L. Rev. 283, 294-95 (1928); infra note 354. But see Am. Mills Co. v. Am. Surety Co. of N.Y., 260 U.S. 360 (1922). It is especially important to note in this context that in Michaelson v. United States, 266 U.S. 42 (1924), the Court, per Sutherland, unanimously reversed "a most powerful Circuit Court of Appeals in an opinion written by a very able judge" and upheld the constitutionality of the provisions of the Clayton Act requiring a jury trial for charges of criminal contempt committed outside the presence of a court. Injunctions and Contempt of Court, 40 NEW REPUBLIC 287 (Nov. 19, 1924). The Circuit Court below had held that Congress "can, as a potter, shape the vessel of jurisdiction, the capacity to receive; but, the vessel having been made, the judicial power of the United States is poured into the vessel, large or small, not by Congress, but by the Constitution," and that the judicial power created by the Constitution required that the "vindication or enforcement" of an equitable decree "must be held to be an inherent power of the equity court, a power within the power to render the decree." Michaelson v. United States, 291 F. 940, 946-47 (7th Cir. 1923). Interposing a jury between the Court and the vindication of its decree was unconstitutional because it undermined the essentials of equitable authority. 
Taft had in the past made very similar arguments. Taft, The Selection and Tenure of Judges, supra note 96, at 214. Upon accepting the Republican Party's nomination in 1912, for example, he had declared that an effort to "interpos[e] a jury in contempt proceedings brought to enforce the court's order and decrees" was "really class legislation designed to secure immunity for lawlessness in labor disputes on the part of the laborers." William H. Taft, Acceptance Speech for the Republican Nomination for President of the United States, Senate Document No. 902, 62d Cong. 2d SESS. (August 9, 1912), at 10.

Although Taft was hostile to the Clayton Act, he very early on developed a narrow construction of its provisions requiring a jury trial. William H. Taft, Address Delivered at the Convention Banquet of the National Association of Manufacturers 9-11 (May 26, 1915); Taft, Address of the President, supra note 109, at 379-80. Adopting a version of the avoidance canon, the Court in Michaelson essentially accepted Taft's narrow reading of the statute. We have evidence that Sutherland was initially planning to write much more broadly, but two weeks before the announcement of the opinion Taft sent Sutherland a letter urging that Sutherland's draft be drastically narrowed:

Is it not unnecessary for us in reaching the conclusion to discuss the question of the difference between judicial jurisdiction and judicial power? ... I put it to you whether it isn't unwise for us, when we have a plain ground upon which to reverse the case and hold the law valid, to enter upon a discussion that leads to a conclusion that might embarrass some of us in the consideration of other cases, because we think there may have to be recognized such a distinction in certain connections. Moreover, is it not unsafe to hold in a case that does not require it that there is a limitation in the grant of judicial power to the United States which would prevent Congress providing for a jury trial in equity cases or in certain issues in equity? I don't say that this may not be the correct view, but when we dispose of this case most satisfactorily, as you have done in the rest of the opinion, isn't it unwise to commit the Court on an issue like this? I suggest that you leave out of the opinion the passage beginning on page 2, immediately after the words "Is the provision of the Clayton Act granting right of trial by jury constitution", and include in the omission also pages 3 , 4,5 and 6 , to the middle of the latter page, where you begin with the sentence "Shortly stated, the statute provides that willful disobedience" et seq.

Letter from WHT to George Sutherland, Justice, U.S. Supreme Court (Oct. 4, 1924) (Taft papers).

Sutherland evidently followed Taft's advice. It is precisely Taft's capacity and will to control the conservative wing of his Court in this way that began to decline in the later years of the decade. Taft was no doubt acutely aware that Michaelson was due to be announced immediately before the 1924 presidential election, when the legitimacy of the Court itself would be a major political issue. Press reception of Michaelson saw "a significant connection between [the] decision and the plan to limit the Supreme Court's powers, which was put forward in the campaign." Labor's "Magna Charta" Upheld, LiTERARY Dig., Nov. 8, 1924, at 12. Robert Cushman celebrated the "soothing influence" of Michaelson "upon a public opinion ... which has been watching with increasing concern the rapid expansion of 'government by injunction.' Necessary as the injunctive process and summary punishments for contempt of court may be, it is a cause for congratulation that the Supreme Court has 
increase the time and expense involved in the disposition of litigation." 304

At root, Taft was hostile to juries because he regarded them as given to "unrestrained impulses" in favor of "local prejudice." 305 Under the "hypnotic influence" of trial counsel, jurors were more likely to produce a verdict that was "the vote of a town meeting than the sharp, clear decision of the tribunal of justice." ${ }^{306}$ Taft despised "the irresponsible action of shrewd and eloquent counsel, able to make the worse appear the better reason, whether engaged for one side or the other. This has the tendency not only to reach emotional, unjust, and wrong results, but it drags out the trial far beyond what is necessary." ${ }^{307}$

Taft viscerally disliked Walsh because "he made his money out of damage suits and criminal law and his attitude is always of throwing the reins on the back of the jury and minimizing the power of the Court." "308 Taft resented plaintiffs' lawyers who sued corporations where "the plaintiff relies on the supposed sympathy of twelve laymen with the poor plaintiff against the rich corporation, both to find the facts in favor of the plaintiff and also to swell the damages to a large sum." ${ }^{309}$ He believed that "[t]he abolition of the jury in civil cases would relieve the public a great burden of expense, would facilitate the hearing of all civil suits and would not, I think, with proper appeal deprive any litigant of all he is entitled to, an impartial hearing." 310

been able to sustain on constitutional grounds such mitigations of the essentially rigorous and sometimes arbitrary nature of these acts of judicial power." Robert E. Cushman, Constitutional Law in 1924-25: The Constitutional Decisions of the Supreme Court of the United States in the October Term, 1924, 20 AM. POL. SCI. REv. 80, 92 (1926).

304. Taft, Delays and Defects, supra note 226, at 853; see Letter from WHT to Henry S. Pritchett (Jan. 17, 1922) (Taft papers) ("[T] he real delay, especially in criminal cases, is due to the jury system . . . and the unwillingness to give to judges the opportunity to guide the jury, which they have in both the English courts and the Federal courts, so that a judge can facilitate the trial, and does, and we have no such scandalously lengthy trial[s] as they do in state courts.").

305. Taft, Criticisms of the Federal Judiciary, supra note 99, at 651-52.

306. Taft, The Administration of Criminal Law, supra note 59, at 13.

307. Taft, The Attacks on the Court, supra note 106, at 20.

308. Letter from WHT to Elihu Root (Jan. 4, 1926) (Taft papers); see also supra note 301 .

309. Taft, The Administration of Criminal Law, supra note 59, at 6.

310. Id. Even in a criminal context, Taft believed that "the jury is the great source of expense and delay, and where it can within constitutional privilege be dispensed with or persuasive opportunity be offered for a waiver of it, it will make for justice by increasing the dispatch of business." Letter from WHT to Francis B. James (Aug. 25, 1921) (Taft papers). 
Taft recognized that "[w]e cannot, of course, dispense with the jury system. It is that which makes the people a part of the administration of justice and prevents the possibility of government oppression." "311 Yet this recognition was largely superficial. Taft could convince himself, for example, that the only "real objection" to labor injunctions was "the certainty that disobedience will be promptly punished before a court without a jury." ${ }_{12}$ Taft was apparently incapable of putting himself into the shoes of someone who believed that judges themselves might be biased officials. He instead instinctively figured judges as disinterested experts, immune to the "buncombe and mere sentiment" produced by counsel. ${ }^{313}$ Taft indissolubly amalgamated a genuine progressive faith in expertise with a less attractive presumption that ordinary folk ought to defer to professional elites, like judges. ${ }^{314}$

311. Taft, Delays of the Law, supra note 101, at 38 . Taft continued, "But every means by which in civil cases litigants may be induced voluntarily to avoid the expense, delay and burden of jury trials ought to be encouraged, because in this way the general administration of justice can be greatly facilitated and the expense incident to delay in litigation can be greatly reduced." Id. See Letter from WHT to P.W. Moir (Nov. 20, 1925) (Taft papers).

312. Taft, Criticisms of the Federal Judiciary, supra note 99, at 672. "It is hardly necessary to defend the necessity for such means of enforcing orders of court. If the court must wait upon the slow course of a jury trial before it can compel a compliance with its order, then the sanctions of its process would be seriously impaired." Id.; see TAFT, PRESENT DAy PROBLEMS, supra note 82, at 270-71; Taft, Judicial Decisions, supra note 49, at 209. Taft regarded the proposal to give the defendant in a contempt proceeding the right to a trial by jury as giving "a defeated litigant the opportunity to have a judgment or decree carefully rendered, reviewed by a jury with every opportunity to appeal to emotion, prejudice and irrelevant circumstances. This is a recall of judicial decision in miniature, but in its way quite as dangerous an innovation." Taft, The Attacks on the Court, supra note 106, at 23. Compare supra note 303.

313. Taft, The Selection and Tenure of Judges, supra note 96, at 214.

314. On traditional English views of the proper relationship between courts and juries, see John LANGBein, RenÉE LETTOW LERNER \& BRUCE SMith, History of THE Common Law: The Development of Anglo-American Legal Institutions 431-33 (2009); Conor Hanly, The Decline of Civil Jury Trial in Nineteenth-Century England 26 J. Legal Hist. 253, 258-62 (2005). On the American departure from traditional English practice, see LANGBEIN, LERNER \& SMITH, supra, at 520-22. See generally Kenneth A. Krasity, The Role of the Judge in Jury Trials: The Elimination of Judicial Evaluation of Fact in American State Courts from 1795 to 1913, 62 U. DET. L. REV. 595 (1985); Renée Lettow Lerner, The Transformation of the American Civil Trial: The Silent Judge 42 WM. \& MARY L. REV. 195 (2000). Both John Wigmore and James Thayer agreed with Taft's views on the proper relationship between judge and jury. See 9 John H. Wigmore, A Treatise on the AngloAMERICAN SySteM OF EVIDENCE IN TRIALS AT COMMON LAW § 2551, at 504-05 (3d 
From his days as a Circuit Justice dedicated to maintaining the access of large national corporations to federal courts through diversity jurisdiction and removal, ${ }^{315}$ Taft deprecated the tendency of States to make a "fetish" of the "institution of trial by jury" 316 by "minimizing the influence and control of the judge over the action and deliberation of the jury" 317 and exalting "the jury's power beyond anything which is wise or prudent." 318 "[S]o jealous have legislatures become of the influence of the court upon the jury that it is now, in most states, made an error of law for the court to express his opinion upon the facts .... The opportunity which this gives the counsel to pervert the law, and the wide scope which the system in restricting the judge gives to the jury of following its own sweet will, of course, doubles the opportunity for miscarriages of justice." ${ }^{319}$

Diversity jurisdiction was important because in the federal system judges "have the power which the English judges have. . . . [T] he court exercises the proper authority in the management of the trial and assists the jury in a useful analysis and summing up of the evidence, and an expression of such opinions as will help the jury to reach right conclusions. All this tends to eliminate much of what almost might be called demagogic discussion which counsel are prone to resort to in many of the local state courts." ${ }^{320}$ National corporations, who were the object of local prejudice, could thus get a fair trial in federal courts in ways that undue deference to juries precluded in state courts. ${ }^{321}$ Federal courts were the "terror of evil-doers" and the

ed. 1940); James B. Thayer, A Preliminary Treatise on Evidence at the COMMON LAW 188 (1898).

315. See supra note 233 and accompanying text.

316. Taft, The Administration of Criminal Law, supra note 59, at 12.

317. Taft, Criticisms of the Federal Judiciary, supra note 99, at 652. Taft believed the federal decision-making fora were necessary because the absence of judicial control allowed the local prejudices of the jury to dominate judicial proceedings, to the systematic disadvantage of national commercial entities. Id.

318. Taft, The Administration of Criminal Law, supra note 59, at 14.

319. Id. at 13 .

320. Taft, The Selection and Tenure of Judges, supra note 96, at 213-14. In state court, "opportunity is too frequently given to the jury to ignore the charge of the court, to yield to the histrionic eloquence of counsel, and to give a verdict according to their emotions instead of their reason and their oaths." Id. at 214.

321. See Taft, Delays and Defects, supra note 226, at 857 ("The creation of an atmosphere of fog and error and confusion is only possible under a system in which the power of the court to control is own proceedings and to guide the jury to some extent in the way in which it should go, is so limited by rules of judicial procedure laid down by legislative enactment that the judge becomes nothing but a moderator of the proceedings and helpless in the hands of an acute and eloquent counsel for the 
epitome of "law and justice" precisely because "the judge retains his traditional control of the manner of the trial and of the counsel." "322

You might imagine the horror that overwhelmed Taft, then, when he discovered not only that Senator Thaddeus Caraway of Arkansas had introduced a bill that would make it reversible error for a federal judge to comment on the credibility of witnesses or the weight of evidence, ${ }^{323}$ but also that Caraway's Bill had noiselessly passed the Senate and been unanimously approved by the House judiciary committee. ${ }^{324}$ Conceiving himself as the guardian of the

defense."); see also Taft, The Courts and the Progressive Party, supra note 104, at 47 ("[S] tate legislatures have cut down the power of the judge so that now in many states he has little more power to exercise than the moderator in a religious conference. In some states he is required to deliver a written charge before argument of counsel, and in others he is permitted only to accept or reject the statements of the law as given by counsel. His opportunity for usefulness is curtailed, his impartiality made the subject of suspicion by most unwise restrictions, and the trial is turned over largely to the control of the lawyers and the little restrained discretion of the jury. The result has been the perversion of justice in jury trials, the infusion into them of much maudlin sentiment and irrelevant considerations, and a dragging out of the trial to such a length that if it be a civil case the cost of litigation is greatly increased, and if it be a criminal case the public come to treat it as a game of wits and eloquence of counsel rather than the settlement of a serious controversy in a court of justice. Neither the dignity nor the effectiveness of judicial administration under these conditions impresses itself upon the public.").

322. Taft, The Selection and Tenure of Judges, supra note 96, at 214.

323. See S. 624, 68th Cong. (1923); 65 ConG. REC. 144 (Dec. 10, 1923). Caraway had been attempting to promote this reform for many years. See e.g., Ashley Cockrill, Trial by Jury, 52 AM. L. Rev. 823, 823 (1918).

324. See H.R. REP. No. 68-816 (May 22, 1924); S. 264, Calendar No. 252, 68th Cong. (1924). Taft was in shock. He wrote to his friend Tom Shelton who was a judicial reformer working for the ABA, that "[i]t is inconceivable that men of the supposed professional standing of Brandegee, Cummins and other could have consented, or allowed to pass, without protest, the adoption of this bill . . . I never supposed that men, in whose conservatism I had great confidence, would lie down as they have done in this case." Letter from WHT to Thomas W. Shelton (Apr. 6, 1924) (Taft papers). "I don't know whether we can induce the new Attorney General [Harlan Stone] to advise the President to veto the bill," Taft wrote his son, "but at least we can try. And then of course the question still arises whether such a provision in accord with the 7th Amendment." Letter from WHT to Robert A. Taft (Apr. 5, 1924) (Taft papers). 
federal judiciary, ${ }^{325}$ Taft sprung into action. ${ }^{326}$ "I am trying to prevent the passage of a bill aimed at the usefulness of the Federal courts," he wrote to his wife,

which seeks to deny to Federal Judges the power to comment on the evidence as the English Judges do. This has always been done in the Federal Courts and has contributed much to their effectiveness. Now these demagogues and damage lawyers are attempting to put the Federal Courts on the basis of the State courts in this regard. The bill has passed the Senate and the Senators yielded supinely, except Reed of Pennsylvania. It has been reported out of the House Judiciary Committee, but I am hoping to hold it over until the next session, in which case I feel fairly confident that I can induce the President to veto it, and I believe his veto would prevent its passage. There is a serious question as to whether it is constitutional, but I would prefer much to have it beaten through a veto than to throw upon the Court the question of its constitutionality. 327

Taft attempted to secure a commitment from the Chair of the House Judiciary Committee to hold hearings on the bill, which Taft hoped would delay legislative action until after the 1924 election, and Taft sought "to have the various Bar Associations... apply to the committee to be heard upon this bill in opposition to it, both on the ground of its doubtful constitutionality and also because of its interference with the efficiency of the Federal courts." ${ }^{328}$

325. See Letter from WHT to Charles Evans Hughes (Apr. 26, 1926) (Taft papers) ("The administration of the law can not be rendered effective unless power is properly entrusted to the Judges. Unless it is so entrusted, the power passes to the counsel engaged in the case, and too often in criminal cases to the counsel for the defendants who has money enough to command the service of the most experienced and acute and powerful criminal lawyers").

326. See Letter from WHT to Thomas W. Shelton (Apr. 13, 1924) (Taft papers) ("The jury bill which passed the Senate was on the Speaker's table and might have been taken up and put right through without reference to the Judiciary Committee of the House, because that committee had reported a similar bill. Graham, however, interfered and secured a reference of the Senate Bill to the committee, and I believe he proposes to have hearings. . . . I haven't had a chance to see Graham, but I have put myself in touch with the Attorney General, who said that he would see him.").

327. Letter from WHT to Helen Herron Taft (Apr. 30, 1924) (Taft papers) ("Congressman Snell, who is the Chairman of the Committee on Rules in the House, promised me that he could postpone the bill. I saw the Chairman of the Judiciary Committee, Mr. Graham, and he thinks he can. I think I shall try and see Nick Longworth, the leader of the House, tomorrow, and with those agreed, I hope the plan of delay can be carried out. It will be a good deal easier to induce the President to veto the bill after the election than before.").

328. Letter from WHT to Thomas W. Shelton (Apr. 13, 1924) (Taft papers). Taft noted, "I am not in a position to appear before the committee myself, because were I to oppose it, it would only sharpen the eagerness of many to put it through." Letter from WHT to Gardiner Lathrop (Apr. 27, 1924) (Taft papers). Taft believed 
Not content with this political maneuvering and mobilization, Taft composed a remarkable Memorandum in opposition to the bill. The cover sheet to the Memorandum, which Taft apparently drafted for his own records, states:

\begin{abstract}
I am exceedingly anxious to beat the bill . . . because it will really greatly interfere with the Federal judicial system. I was able to hold the bill off last session through Chairman Graham and Snell of the Rules Committee in the House. I have been to see the Attorney General once or twice about it and I saw the President this morning and asked him to read this memorandum. I am quite sure that he will be inclined to veto the bill, but it ought not to come to him, and I think the Attorney General suggests his sending for Graham and Nick Longworth to see whether it can not be shelved. I submitted the memorandum to Van De Vanter [sic] and he fully approved the statement, but he thought that I put a little too much admiration for the English in it. However, as this is not to be published and is only a confidential memorandum for the President and the Attorney General [Harlan Stone], and as I have only given out one copy in addition to that given to Van Devanter, there is no occasion for changing my view which is
\end{abstract}

that support for the bill arose from the fact "that many of the lawyers in the Senate and the House are damage lawyers and do not welcome the mode of procedure in the Federal Courts. The only thing that can be done is to have the Bar Associations of the various States and cities, who can be roused to the necessity of it, apply for an opportunity to be heard by the Judiciary Committee of the House, where the bill now is, in order to present objections to the bill. I am informed that Mr. Graham [Chair of the House Judiciary Committee] is opposed to the bill and is making an effort to carry it over to the next session, so that it may be considered after, rather than before, the Presidential election." Id.

On the opposition of the ABA to the measure, see The Effort to Limit Power of Federal Judges, 10 A.B.A. J. 303 (1924) ("The bill is part and parcel of a vicious plan to destroy the powers and independence of the Federal Judiciary, and to invade its constitutional prerogatives."); An Unwise Measure, 10 A.B.A. J. 332 (1924) ("[T]he proposal is wholly indefensible... The indisputably greater efficiency of the federal courts as compared with the vast majority of state courts, of English criminal courts as compared with our own, rests on the power which the presiding judge has to control the proceedings."). There were also dissenting voices. See Letters of Interest to the Profession, 10 A.B.A. J. 443 (1924) (arguing in opposition, C. Floyd Huff wrote, "[A] jury trial is a mockery far more so under a system which permits a Judge to make the last argument to the jury"); id. at 443-44 (presenting Alvah J. Rucker's arguments). Compare Harry Eugene Kelly, An Impending Calamity, 11 A.B.A. J. 65 (1925), with Curbing Federal Judges, 28 LAw Notes 182 (1925).

Shelton cleverly planted a story in the Louisville Times to the effect that the adoption of the bill would have an "immediate" effect "upon the enforcement of the Volstead Law ... and we can but believe that the enemies of the liquor laws are the ones most active in pushing it." LOUISviLle TiMES, Apr. 28, 1924. Shelton sent the clipping to Taft with a note: "Don't answer, but just watch the effect of this on the prohibitionists." (Taft papers). 
stated herein, or ameliorating it with reference to prejudices against England. ${ }^{329}$

The Memorandum itself is a twelve-page document arguing that the Caraway bill would greatly "weaken the usefulness and efficiency of Federal Courts in the dispatch of business involving jury trials." ${ }^{330}$ "This bill, if it passes, is calculated to reduce the condition in the Federal Courts to the ineffectiveness of State Courts." ${ }^{331}$ On page six, the Memorandum addresses the "question ... whether Congress may by law effect this demoralizing assault on the trials in our Federal Courts. Fortunately the right of the Judge to exercise this power of summing up to a jury upon the facts is conferred upon him by the Constitution of the United States, and can not be taken away by legislation." ${ }^{332}$ The remainder of the Memorandum constitutes a detailed argument for this proposition, concluding:

In view of these authorities, it can not be that Congress may take away the power of a Judge of a United States Court in carrying on a jury trial, to comment on the evidence and even express his opinion on the facts, if he leaves the question of facts clearly to the jury ultimately. It was an essential element of a jury trial in the English courts when the Declaration of Independence was signed and our Constitution was framed and adopted and when the 7th Amendment became part of it. That being true, Congress may not impair the institution by attempting to restrain Federal Judges from the discretion to exercise the power vested in them by the fundamental law. ${ }^{333}$

The Memorandum is a stunning document. It is a fully developed advisory opinion, crafted by Taft for the explicit purpose of affecting the outcome of legislation. Taft must have known that the Memorandum was ethically suspect, because he showed it only to his most trusted confidant, Van Devanter, and he strictly curtailed its dissemination outside the Court. Taft at first circulated the Memorandum only to the President. But as Caraway continued to

329. Memorandum from William Howard Taft (Dec. 2, 1924) (Taft papers).

330. Id. at 1 .

331. Id. at 5 .

332. Id. at 6 .

333. Id. at 12. In contrast to Taft's request to Sutherland in Michaelson to downplay the distinction between judicial power and jurisdiction in the context of the Clayton Act's requirement of a trial by jury for criminal contempt committed outside the presence of the court, see supra note 303, Taft was apparently in other contexts quite willing to emphasize the distinction. See, e.g., Letter from WHT to Clarence H. Kelsey (Sept. 12, 1922) (Taft papers) ("Should there be a progressive majority in the House and Senate, it is quite probable that they would attempt to cut down the jurisdiction of the Federal Courts, as they may do by a mere act of Congress, but when it comes to interfering with our powers under the Constitution, they need two-thirds of each House and three-fourths of the states."). 
press his legislation, Taft grew bolder. He wrote to his brother Henry that "[w]e stopped the Caraway bill to take away the power of the Federal Judges in charging a jury, and I am going to take time by the forelock to prime Senator David Reed of Pennsylvania on the probable unconstitutionality of such a law." 334 Taft sent Henry a copy of his Memorandum, ${ }^{335}$ and he suggested that Henry "open a correspondence with the only man who opposed it in the Senate, and that was Senator Reed of Pennsylvania. You might send a copy of it also to Senator Cummins and another one to Senator Gillett. Don't make me the author of it, for reasons that you will understand." ${ }^{336}$

Over the next several years, Taft managed repeatedly to kill the Caraway bill, ${ }^{337}$ and his tactics never erupted into scandal, although

334. Letter from WHT to Henry W. Taft (Mar. 27, 1925) (Taft papers).

335. See Letter from Henry W. Taft to WHT (Mar. 28, 1925) (Taft papers).

336. Letter from WHT to Henry W. Taft (May 28, 1925) (Taft papers). Henry responded by sending Taft a "copy of the proposed report of the [ABA] Committee on Jurisprudence and Law Reform," which he "prepared some weeks ago." Letter from Henry W. Taft to WHT (May 29, 1925) (Taft papers). Henry noted that Taft "w[ould] see from the report" that he "used [Taft's] memorandum on the Caraway bill freely" and added something of his own. Id. Taft approved Henry's report, adding, "The point is that the parties are entitled to have the benefit of the discretion of the Judge in aiding the jury . . . and there are many cases where it is absolutely necessary in order that the jury may understand what the issues are and in order to clear the atmosphere of the court room from the utterly irrelevant appeals of counsel. We must have a jury system in order to reconcile the people with the administration of justice, and the only way by which it has been made possible in England is by the power of the Judge to prevent injustice by explaining to the jury the situation, the relevancy of the facts and his judgment on the weight of them, in order to enable them to exercise their exclusive function of ultimately weighing the facts." Letter from WHT to Henry W. Taft (May 31, 1925) (Taft papers).

337. When Caraway continued to press his bill, Taft wrote to his brother, "[T]he bill has heretofore been beaten through the Judiciary Committee of the House by the active resistance of Chairman Graham. I hope he may do the same thing again if the bill gets through the Senate this session. I enlisted the assistance of the President in suppressing the bill, because he is very much opposed to it, and I think I could induce him to veto it. The last time he urged Gillett and Longworth and Graham to shelve the bill, and they did it. I hope that may be done this year." Letter from WHT to Henry W. Taft (May 18, 1926) (Taft papers); see also Letter from WHT to Robert A. Taft (Feb. 6, 1927) (Taft papers) ("We have staved off a bill which has been pending in each Congress to take away the right of the Judge to comment on the evidence in Federal trials .... I very much doubt whether under our Federal Constitution, Congress could take away the power of the judge."); Letter from WHT to Horace D. Taft (Mar. 3, 1928) (Taft papers) ("The Democratic Senate is doing everything that I don't like to have them do, but I suppose that is to be expected. They have just passed a bill taking away from the Federal Courts the power of the Judge to comment on the evidence in submitting a case to the jury. We hope that we can hold it up in the House, but I don't know whether we can or not. I think I could induce the 
this seems mostly a matter of luck. Taft's passion for efficient judicial administration betrayed him into actions that could scarcely be defended in public. Of course, on the other side of the coin, it is no doubt due to Taft's vigorous intervention that federal judges enjoy to this day the traditional common law prerogative to comment on the weight of evidence and the credibility of witnesses. 338

The incident nicely reveals the tension between traditional American conceptions of judicial propriety and Taft's conception of the Chief Justice as a kind of English Lord Chancellor. In 1922, Taft agreed to chair an ABA committee charged with drafting the first American canons of judicial ethics, which were approved in $1924 .{ }^{339}$ Canon 23 explicitly supports Taft's long held view that "a judge has exceptional opportunity to observe the operation of statutes, especially those relating to practice, and to ascertain whether they tend to impede the just disposition of controversies; and he may well contribute to the public interest by advising those having authority to remedy defects of procedure, of the result of his observation and experience." ${ }^{\prime 340}$ The

President to veto it, but whether it would pass over the veto I can not say; and after that would come the question whether the bill is constitutional .... If Al Smith gets in, and the Democrats have control of both Houses, the next four will not furnish a rosy bed, even for Justices of the Supreme Court.").

338. See Jack B. Weinstein \& Margaret A. Berger, Weinstein's Federal EvidENCE $§ 107$ (Joseph M. McLaughlin ed., 1994); 9A RONALD F. WRIGHT \& MARC L. Miller, Federal Practice and Procedure 2d § 2557 (1995); see also Quercia v. United States, 289 U.S. 466, 469 (1933) ("In a trial by jury in a federal court, the judge is not a mere moderator, but is the governor of the trial for the purpose of assuring its proper conduct ....").

339. See generally Final Report of the Committee on Judicial Ethics, 46 AnN. REP. A.B.A. 452 (1923) (publishing Taft's draft of the canons to the ABA at its 1923 annual meeting). See also Walter P. Armstrong Jr., The Code of Judicial Conduct, 26 SMU L. REV. 708, 708-10 (1972). A copy of the 1924 Canons may conveniently be found as Appendix D in Lisa L. Milord, The Development of THE ABA Judicial CODE 131-42 (1992).

340. Final Report of the Committee on Judicial Ethics, supra note 339, at 458. An earlier draft of this Canon was far more explicit:

Judges have a peculiar opportunity to observe the operation of statutes, especially those relating to practice, and to ascertain whether they tend to impede the reasonable and just disposition of controversies; they should not be indifferent to shocking results; and they may well contribute to the public interest by advising both the people and their representatives of the result of their observations and experience; there is no need of diffidence in this respect, out of a false fear of being considered to be unduly interfering with another department of the Government.

Judges may well direct diligent effort toward securing from proper authority such modification of laws or rules tending, in their experience, to 
contemporary Model Code of Judicial Conduct continues this tradition in Rule 3.2:

\begin{abstract}
A judge shall not appear voluntarily at a public hearing before, or otherwise consult with, an executive or a legislative body or official, except: (A) in connection with matters concerning the law, the legal system, or the administration of justice; (B) in connection with matters about which the judge acquired knowledge or expertise in the course of the judge's judicial duties. ${ }^{341}$
\end{abstract}

Yet American judges, in contrast to those of England, may well have to pass on the constitutionality of legislation implementing procedural reform. Taft's Memorandum was unethical precisely because it passionately prejudged a potentially impending constitutional case. Concern with the appearance of prejudgment when advocating for procedural reform is entirely absent from the 1924 Canons ${ }^{342}$ whereas the contemporary Model Code of Judicial Conduct explicitly states that in "consulting with government officials, judges must be mindful that they remain subject to other provisions of this Code, such as ... Rule 3.1(C), prohibiting judges from engaging in extrajudicial activities that would appear to a reasonable person to undermine the judge's independence, integrity, or impartiality." ${ }^{343}$

In 1921, two months after his confirmation as Chief Justice, Taft pledged to the ABA that he would stay continually involved in the cause of judicial reform, ${ }^{344}$ casually laughing off the possibility of potential conflicts of interest: "If a judge on an occasion like that advances an opinion on a question of law which might subsequently arise in a case before him, he is a pretty poor judge if he cannot ignore

impede or prevent the reasonable and just disposition of litigation, as will rectify the evils discovered by them.

Letter from Charles Boston to WHT (June 8, 1922) (Taft papers). Taft's hand is evident throughout the Canons as, for example, in their strong emphasis on the need for an efficient, speedy, and effective judiciary. See, e.g., Final Report of the Committee on Judicial Ethics, supra note 339, at 455, 457 (referring to the language of Canons 2, 6, 7, 8, 18).

341. Model Code of Judicial Conduct r. 3.2 (AM. Bar Ass'n 2014).

342. Canon 33 comes closest to expressing this concern. It provides that a judge should "in pending or prospective litigation before him be particularly careful to avoid such action as may reasonably tend to awaken the suspicion that his social or business relations or friendships, constitute an element in influencing his judicial conduct." Final Report of the Committee on Judicial Ethics, supra note 339, at 460 (presenting Taft's draft for Canon 33).

343. Am. Bar Ass'n, Model Code of Judicial Conduct r. 3.2 cmt. [2] (2014).

344. See Taft, Possible and Needed Reforms, supra note 101, at 607. 
the opinion he has already expressed." ${ }^{345}$ But no one who read Taft's Memorandum would regard it as a laughing matter; no one would regard him as free from prejudicial prejudgment. As is plainly apparent in today's Model Code of Judicial Conduct, Taft bequeathed to American judges a deep and intractable tension between, on the one hand, the prerogatives of expertise and experience, and, on the other hand, the need to maintain the appearance of impartiality and independence.

Taft lived the entire span of his Chief Justiceship in the throes of this tension. ${ }^{346}$ The danger of constitutional prejudgment lurked in even the seemingly most technical and innocuous of measures. Consider, for example, Taft's involvement in the passage of a bill that transferred jurisdiction of patent appeals from the Court of Appeals of the District of Columbia to the Court of Customs Appeals. Taft strongly supported the bill, to the extent that Acting Commissioner of Patents William A. Kinnan could in congressional hearings testify that "[t]here has been no objection anywhere. It has been indicated that the Chief Justice of the United States has looked into it and approved it. It seems to me to be an efficiency measure." ${ }^{347}$

Taft wrote to Walsh urging approval of the bill on the ground that the District Court of Appeals was "very much burdened with business," while the Court of Customs Appeals did "not have enough to do." ${ }^{348}$ Despite his private views of Walsh, Taft was sweetly and nonpartisanly solicitous: "I am sorry to impose on you, my dear Senator, another burden, but as I understand you are on the committee for the consideration of this bill, I venture thus to write to you. It will certainly help the administration of justice in the District." ${ }^{349}$ From a modem point of view, it is striking that Taft included in his letter a long defense of the bill's constitutionality, which began:

I understand that there are two persons who think that the bill is unconstitutional. I can not for the life of me understand how any such doubt

345. Taft, After-Dinner Oratory at Cincinnati, supra note 288, at 606.

346. Only three days after being confirmed as Chief Justice, Taft wrote Daugherty proposing a reform that Taft acknowledged came "close to the Constitution." Letter from WHT to Harry M. Daugherty (July 3, 1921) (Department of Justice Files, No. 144446, Section 2). Taft was perfectly aware of the constitutional controversy that surrounded the recommendation that he had pushed the Judicial Conference to announce in 1925 that bail be routinely denied after conviction. See supra note 167 and accompanying text.

347. Change in Title of the United States Court of Customs Appeals: Hearing on H.R. 6687 Before the H. Comm. on the Judiciary, 70th Cong. 6 (1928).

348. Letter from WHT to Thomas J. Walsh (May 8, 1928) (Taft papers).

349. Id. 
could arise. The Court of Customs Appeals is a purely statutory court, and Congress is not limited in any way in the functions which it gives to it. ${ }^{350}$

Walsh replied to Taft that he would "make an effort to have the matter put in" shape for approval, ${ }^{351}$ and the bill, seemingly uncontroversial, was enacted into law on March 2, 1929. 352

It is remarkable that Taft would submit an advisory opinion about the constitutionality of a bill to a Senator who was in many ways his arch-opponent. It indicates how unembarrassed Taft must have felt about the practice. ${ }^{353}$ This is probably because he regarded the

350. Id.

351. Letter from Thomas J. Walsh to WHT (May 10, 1928) (Taft papers). The next day Taft wrote to A.C. Paul, "I sincerely hope that [Walsh] will be able to get the bill through. I fear that the Chief Justice of the Court of Customs Appeals will try to prevent it, but I hope not." Letter from WHT to A.C. Paul (May 11, 1928) (Taft papers).

352. See Pub. L. No. 70-914, 45 Stat. 14751929.

353. Thus Taft wrote his brother about the Uniform Procedure Bill that he was anxious to have passed:

I am especially anxious with reference to the power that it gives the Court to unite equity and law.... Of course the suggestion that it is not constitutional is perfectly ridiculous. After we have been making rules for admiralty and equity since the beginning of the Government, to say that we can not make rules for common law procedure is something that nobody but an Irishman with a certain keenness of mind and without any sense of humor would solemnly advance.

Letter from WHT to Henry A. Taft (May 21, 1926) (Taft papers); see also supra note 299 and accompanying text (presenting and addressing Walsh's constitutional arguments to the contrary); Letter from WHT to Albert B. Cummins, Senator, U.S. Senate (May 31, 1926) (Taft papers) (arguing in favor the constitutionality of the uniform procedure bill authorizing the Supreme Court to make rules of procedure for common law actions). See generally Liberty Oil Co. v. Condon Bank, 260 U.S. 235 (1922) (forming the basis for Taft's argument in his May 31, 1926, letter to Albert B. Cummins).

Apparently, however, the practice of advisory opinions was not confined to Taft. So, for example, the normally reticent Van Devanter wrote to Congressman R. Walton Moore:

I have ... read with much interest the paper you have prepared relating to the proposed relief of the District Courts by providing for the trial of minor criminal proceedings before some subordinate judicial officer, with a right to appeal from a conviction.

The paper rightly ... is thoroughly well grounded in its portrayal of what constitutionally may be done if deemed expedient .... No criticism occurs to me that would be helpful.

Letter from WVD to R. Walton Moore, Congressmen, U.S. House of Representatives (Jan. 12, 1927) (Van Devanter papers). Cf. 67 ConG. REC. 10942-43 (June 8, 1926). For other examples of Van Devanter engaging in constitutional prejudgment, see, e.g., Letter from WVD to R. Walton Moore, Congressmen, U.S. House of Representatives (May 29, 1929) (Van Devanter papers); Letter from WVD to Charles W. Bunn (Apr. 
constitutional issue posed by the statute as uncontroversial and settled. Yet constitutional judgment in the United States is seldom a secure thing. Taft premised his argument on the fact that the Court of Customs Appeals was an Article I court, yet within only thirty years Congress would itself declare the (now renamed) Court of Customs and Patent Appeals an Article III court, ${ }^{354}$ a conclusion sustained by the Supreme Court of the United States. ${ }^{355}$

From this perspective, the potential for pre-judging a possible constitutional case lay coiled within virtually every recommendation Taft made for judicial reform. Even the institutional voice of the Judicial Conference, which Taft created in part to provide support for such reform, offered no defense to this danger. A good example may be found in the story of Taft's attempt to relieve federal courts of the flood of small criminal cases that Prohibition swept into their jurisdiction. Not only did these cases clog the docket, but federal judges found them intensely demoralizing. ${ }^{356}$

2, 1928) (Van Devanter papers) ("There may be doubt of the power to do what is proposed in the bill altering the functions of judges in jury trials.").

354. See Pub. L. No. 85-755, 62 Stat. 899 (1958).

355. See Glidden Co. v. Zdanok, 370 U.S. 530 (1962); see also Brenner v. Manson, 383 U.S. 519, 526 (1966).

356. See Letter from WHT to Charles Evans Hughes (Mar. 13, 1926) (Taft papers). Augustus Hand wrote Taft, "Our only real relief is to get rid of petty criminal cases. If we do not do this, this court which has been one of the most important and interesting trial courts anywhere is bound, in my opinion, to sink to a very low level." Letter from Augustus N. Hand, Judge, S.D.N.Y., to WHT (Dec. 9, 1925) (Taft papers). Exemplary is Henry Smith's letter to Taft explaining why he was retiring as a federal district judge:

I am not conscious of any disability, physical or mental, and would dislike to be considered "shirking," but the burden of the immense criminal business of a police character - especially the flood of liquor cases-has become very great. They involve no questions of legal importance. Just one small criminal case after another, depending wholly upon testimony as to the facts. My egotism, I suppose, persuades me that I am a little thrown away on such work, and impels me to think I had better turn it over to a younger, stronger, and less susceptible mind.

Letter from Henry A.M. Smith, Judge, U.S. Dist. E. S.C., to WHT (May 23, 1923) (Taft papers); see also Editorial, 1 AM. MERCURY, No. 2, Feb. 1924, at 161, 161 (Feb. 1924) ("Perhaps the chief victims of Prohibition, in the long run, will turn out to be the Federal judges. . . . A dozen years ago, or even half a dozen years ago, a Federal judge was perhaps the most dignified and respected official yet flourishing under our democracy. .. I I describe a Golden Age, now lamentably closed. The Uplift in its various lovely forms has completely changed the character of the work done by a Federal judge. Once the dispenser of varieties of law that only scoundrels questioned, he is now the harassed and ludicrous dispenser of varieties of law that only idiots approve. ... [I]t is Prohibition ... that has carried him beyond the bounds of what, to 
Almost from the day he took office, Taft believed that legislation was needed to allow United States Commissioners to try such cases. ${ }^{357}$ In 1923, at the second meeting of the Conference of Senior Circuit Judges, Taft pushed through a resolution to the effect that "[i]n prohibition and other misdemeanor cases" U.S. Commissioners be authorized "in all cases in which the defendants do not file written demands for jury trial, to take and file written pleas of guilty and to hear the evidence on pleas of not guilty and to file in court their reports of the cases and their recommendations of what judgment should be entered." "358 Taft regarded this resolution as one of the "most important" of the Conference. ${ }^{359}$

The recommendation went nowhere, however, and so at the end of 1925 Taft sought, on his own initiative, to revive the plan. He wrote to George S. Graham, Chair of the House Judiciary Committee, and to Senator Albert Cummins, Chair of the Senate Judiciary Committee, that he was "very much troubled about the conditions that prevail in the District Courts of the United States. They are being demoralized by this police court business." Taft proposed an elaborate legislative scheme to remedy the situation:

How would this suggestion strike you? Provide that in every District there should be appointed a Judicial Commissioner to serve during good behavior, that he should have authority to hold court, try jury trials and have jurisdiction to try misdemeanors and felonies, punishment for which shall not exceed two years' imprisonment; that he should be given the power to compel the defendants to elect whether they desire jury trials within ten days after the filing of the information or the indictment; that he should be required to act also as a regular United States Commissioner, and might be

most normal men, is common decency. His typical job today ... is simply to punish men who have refused or been unable to pay the bribes demanded by Prohibition enforcement officers. In other words, he is now chiefly apprehended by the public ... as an agent of rascals and a scourge of peaceable men.").

357. Indeed, in nominating Taft, Harding had announced that he expected Taft to move rapidly to remedy the congestion overtaking federal courts. See Letter from Gus Karger to WHT (June 30, 1921) (Taft papers) ("Additional judges will be needed, [and] ... there may be need of authorization of commissioners; something must be done to relieve the courts of cases of the less criminal type. I mean cases growing out of the Volstead act."); see also George F. Authler, Taft Confirmed by Senate for Post of Chief Justice, MinNEAPOLIS MORNING TRIB., July 1, 1921, at 1.

358. The Federal Judicial Council, 2 Tex. L. Rev. 458, 461 (1924). The Conference noted that this reform "would be expedient, provided the machinery proposed is within constitutional limits." Id. (emphasis added); see also supra note 160 and accompanying text. On the question of constitutionality, see Felix Frankfurter \& Thomas G. Corcoran, Petty Federal Offenses and the Constitutional Guaranty of Trial by Jury, 39 HARV. L. REV. 917 (1926).

359. Letter from WHT to Horace D. Taft (Sept. 30, 1923) (Taft papers). 
called upon by the District Judge to act as a Master in Chancery or a Referee. ... I don't think he thought to be appointed by the President, but that as Judicial Commissioner he might be regarded as an inferior officer, and under the Constitution he could be appointed by the District Court .... Can not you think this over and frame a bill? Something ought to be done. I just throw out this suggestion, with the hope that it may germinate into something. ${ }^{360}$

Six months later, in the course of debate on a bill to authorize the appointment of additional district judges, Graham observed on the floor of the House that he was "in conference with representatives of the Senate Judiciary Committee and some of the judges of the Supreme Court trying to work out some scheme by which the courts of the United States might be relieved of some of the very heavy burdens which they are now obliged to carry." 361 Graham pledged to "strive to create some plan by which a minor judiciary may be created." 362 Representative Duncan Denison of Illinois rose to inquire into "the wisdom of taking into these conferences, in trying to work out legislation that will relieve the courts of a part of their work, the members of the Supreme Court. Does the gentleman think that is a

360. Letter from WHT to Albert Cummins, Senator, U.S. Senate (Dec. 3, 1925) (Taft papers); Letter from WHT to George Graham, Congressman, U.S. House of Representatives (Dec. 3, 1925) (Taft papers). Ever tactful, Taft also sent a similar letter to Senator Walsh, the most influential Democrat on the Senate Judiciary Committee. See Letter from WHT to Thomas Walsh, Senator, U.S. Senate (Dec. 3, 1925) (Taft papers). Walsh replied, "We are so near together in our ideas concerning the measure for the relief of the District Judges that there should be no difficulty in meeting each other's views." Letter from Thomas Walsh to WHT (Dec. 4, 1925) (Taft papers). Walsh preferred, however, to lodge the appointment power in the President rather than in District judges. See id. Taft responded that he did "not wish to insist on the appointment by the District Judges" and that he would be "glad to talk further with you about it, because something ought to be done." Letter from WHT to Thomas Walsh (Dec. 5, 1925) (Taft papers). Taft also asked Augustus Hand for comments on the proposed legislation. Hand responded, "Of course I am heartily in favor of such a plan though I have not looked up the law and do not know whether the appointment of magistrates for such a tribunal as you propose can be delegated to the courts." Letter from Augustus N. Hand, Judge, S.D.N.Y., to WHT (Dec. 9, 1925) (Taft papers).

361. 67 Cong. REC. 10942 (June 8, 1926).

362. Id. Graham continued:

One of the great difficulties has arisen by reason of the invasion of what belonged heretofore to the States alone through the adoption of the eighteenth amendment. By the adoption of that amendment a great burden of police work was cast upon the Federal Government without furnishing that Government the proper equipment and machinery for carrying on the work created by the adoption of the eighteenth amendment and the laws intended to carry it into effect. That is one reason why the business of the courts is suffering, why the courts are congested ....

Id. 
wise policy?"363 Thrown on the defensive, Graham quickly backpedaled:

Mr. GRAHAM. Well, without passing any opinion upon the wisdom of the policy, it came about without our solicitation and we attended simply as conferees.

Mr. DENISON. In the constitutional convention ... that theory was abandoned as being unwise, the theory of having the Supreme Court advise the Congress as to legislation, and I think if we should return to that policy it would be a dangerous one.

Mr. GRAHAM. I may say that this conference arose and was called through the intervention of the Supreme Court judges, upon one of whom, the Chief Justice, there depended the duty of reviewing the work in the district courts all over the United States in the congested districts and trying to provide a remedy. He simply called the chairman and the ranking member of each Judiciary Committee in to ask them to take up the subject and see if there could not be some plan devised. That is all.

Mr. DENISON. What I have in mind is this. Suppose the Congress should enact legislation that is intended to create some sort of subordinate courts to relieve the other courts of some of their duties, and afterwards the constitutionality of the legislation should be raised in the courts, if the Supreme Court had been consulted and advised in the preparation of the law, it seems to me it would be embarrassing, and I do not believe the committee of the House ought to do that.

Mr. GRAHAM. I think, perhaps, ethically the gentleman is correct, and I am not going to dispute that proposition, but I do say it was perfectly competent for those who had charge of the court business throughout the country to call our attention to it and ask us to take it up independently; and that is all that was done.

Mr. DENISON. I see no objection to that.

Mr. GRAHAM. That is all that was done. They would not be taken into consideration in framing the legislation for the legislative duty would rest upon the House and the Senate. ${ }^{364}$

Graham deftly defused Denison's challenge by asserting that Taft (and, he might have added, the Judicial Conference) had merely called the attention of Congress to a problem in need of solution, without proposing any particular legislative response. But Graham was playing fast and loose with the facts as we know them from Taft's correspondence and from the recommendations of the Conference. Had the truth been known, Taft's "embarrassment" might have been far more acute.

363. Id.

364. Id. at 10942-43. 
Taft took the point. When federal district judge Frances Caffey subsequently wrote him to inquire about the status of the 1923 recommendation of the Conference of Senior Circuit Judges so that he could more effectively lobby for bills expanding the jurisdiction of United States Commissioners then pending before Congress, ${ }^{365}$ Taft responded with uncharacteristic caution: "I have to be careful in taking part myself in the preparation of such a bill, because any bill is likely to come before our Court for interpretation and inquiry into its validity." $" 366$

Taft's conception of the Chief Justiceship led to even deeper contradictions than the specific possibility of prejudicial constitutional prejudgment. Taft was well aware that an American judge was

365. See Letter from Francis G. Caffey to WHT (Mar. 17, 1927) (Taft papers). See, e.g., Hearings Before the House Committee on the Judiciary on H.R. 5608, H.R. 8230, H.R. 8555, and H.R. 8556, 70th ConG. 13 (1928) (testimony of Francis G. Caffey referring to the 1923 recommendation of the Conference of Senior Circuit Court Judges).

366. Letter from WHT to Francis G. Caffey (Mar. 21, 1927) (Taft papers) ("[B]ut my interest in it is deep, and I am glad to express the hope that united action will be taken to have the next Congress approach the subject and do the best it can."). Pushed by Representative Walton Moore of Virginia, debate on expanding the powers of United States Commissioners continued sporadically throughout the decade. See, e.g., Letter from WHT to Walton Moore, Congressman, U.S. House of Representatives (Mar. 21, 1927) (Taft papers); Letter from Walton Moore to WHT (Mar. 22, 1927) (Taft papers); Letter from WHT to Walton Moore (Mar. 23, 1927) (Taft papers). The Wickersham Commission also endorsed legislation of this kind. See George Cochran Doub \& Lionel Kestenbaum, Federal Magistrates for the Trial of Petty Offenses: Need and Constitutionality, 107 U. PA. L. ReV. 443, 452-53 (1959). Taft wrote to Hoover to advocate for legislation expanding the role of commissioners. Letter from WHT to Herbert Hoover, President, U.S. (Mar. 14, 1929) (Taft papers). Hoover, Taft told his brother, "ought to propose a law for the disposition of the police work in the enforcement of the prohibition act by enacting a law which shall enable the Government to try petty cases without a jury and punish by a small fine of $\$ 100$ or $\$ 200$, and from ten to sixty days imprisonment. That will require a test of its validity in our Court, but it ought to be done at once, and that would clear up the situation." Letter from WHT to Horace D. Taft (Mar. 10, 1929) (Taft papers). "Of course," Taft added in a subsequent letter, "I don't want to give you the impression that I am certain that the Constitution can be so construed as to get rid of petty cases without a jury. I only wanted to say to you that there are a number of good lawyers who think it is possible, and that it would be worth while, in view of the practical advantages such a construction would give, to have the question tested. A man often entertains a general view of a possible constitutional construction until he is brought face to face with it in a court room and becomes charged with the responsibility of meeting it in a declaration of our Court." Letter from WHT to Horace D. Taft (Mar. 20, 1929) (Taft papers). Evidently, Taft had by the end of the decade become a good deal chastened in the freedom with which he was willing publicly to prejudge constitutional questions. 
expected to "keep out of politics and out of any diversion or avocation which may involve him in politics." 367 But it was not possible for a Chief Justice who regarded himself as the guardian of the federal judiciary to maintain any such separation. A telling example is Taft's opposition to S. 3151, a bill sponsored by Progressive Republican Senator George Norris of Nebraska and strongly supported by Democratic Senator Thomas Walsh. ${ }^{368}$ The bill stripped federal district courts of both federal question jurisdiction and diversity jurisdiction. ${ }^{369}$ By a stroke of great irony, Norris, who thoroughly disliked federal courts - he had actually once proposed abolishing all federal courts except the Supreme Court—was the Chair of the Senate

367. Taft, To the Readers of The Tribune, supra note 272. It is plain, however, that Taft was involved in active legislative horse-trading, even with his nemesis Walsh, in order to secure the passage of legislation increasing the number of judgeships. See, e.g., Letter from WHT to Frederick H. Gillett, Senator, U.S. Senate (Feb. 23, 1927) (Taft papers); Letter from Frederick H. Gillett to WHT (Feb. 23, 1927) (Taft papers); Letter from WHT to Frederick H. Gillett (Feb. 25, 1927) (Taft papers); Letter from Charles H. Parkman to WHT (Feb. 26, 1927) (Taft papers). Taft nevertheless frequently joked about his ineptitude as a politician by way of certifying that his efforts to achieve judicial reform were merely the bona fide efforts of a professionally disinterested judge. Thus, he told the Chicago Bar Association in December 1921, "I seem to have heard a suggestion by way of friendly criticism, when my name was up for the Chief Justiceship, that a politician was being put upon the bench. All I have to say is, that that was news to me (renewed and increasing laughter), and I think it was news to the people." The Chief Justice, supra note 230, at 9. Two years later, Taft would write to Coolidge, "Nobody ever accused me of being a politician, except Borah when he opposed my confirmation as Chief Justice, and I do not claim to be at all versed in the science of practical politics." Letter from WHT to Calvin Coolidge, President, U.S. (Dec. 22, 1923) (Taft papers). "I preferred the office of Chief Justice to that of President," said Taft, "because I prefer the study and decision of legal questions to the executive and political duties of the President." Letter from WHT to Fred E. Campbell (May 6, 1925) (Taft papers).

368. See S. 3151, 70th Cong. (1928).

369. A year earlier, Brandeis wrote Frankfurter essentially recommending such a bill. Letter from LDB to FF (May 11, 1927), in BRANDEIS FRANKFURTER CORRESPONDENCE, supra note 41, at 292. 
Judiciary Committee. ${ }^{370}$ S. 3151 was reported favorably by the Senate Judiciary Committee without even a hearing. ${ }^{371}$

Taft was appalled by what he regarded as "the remarkable effort made in the Senate by Norris and Walsh to emasculate the jurisdiction of the Federal trial courts ... and to sneak it through without the country's being advised about it." $372 \mathrm{He}$ saw the bill as "a great attack on the administration of justice in this country," 373 the "most radical bill affecting the usefulness and efficacy of the Federal Judiciary that I remember ever to have heard suggested." ${ }^{374}$ Taft threw himself into the task of "trying to save the life of the Federal Judiciary." 375

It quickly became apparent, however, that Taft's opposition to S. 3151 could not be confined to anodyne expressions of nonpartisan expertise. Thus when Taft wrote "to sound an alarm on the subject" to

370. See 62 CoNG. REC. 5108 (1922) ("In my judgment we ought to abolish every United States district court in America; we ought to abolish entirely the United States Court of Appeals, and leave nothing of our United States judicial system except the Supreme Court of the United States. We ought to give to State judges and State courts all the jurisdiction."); Letter from George Norris, Senator (R-NE), U.S. Senate, to G. Jay Clark (Jan. 2, 1928) (Norris papers) ("In fact, I have gone so far as to advocate the abolition of all Federal courts except the Supreme Court.").

371. See S. REP. No. 70-626, at 2 (1928) ("The committee can conceive of no reason why the district court of the United States should have jurisdiction in these cases.").

372. Letter from WHT to Horace D. Taft (Apr. 16, 1928) (Taft papers).

373. Letter from WHT to George W. Wickersham (Mar. 29, 1928) (Taft papers).

374. Letter from WHT to Newton Baker (Apr. 5, 1928) (Taft papers). Taft blasted the Senate as "a most Bolshevik body, and the House is the only one that retains any conservatism at all." Letter from WHT to George W. Wickersham (Mar. 29, 1928) (Taft papers). Wickersham replied sympathetically that it was "discouraging to lovers of our institutions, but then, after all, we have had a running fight ever since the enactment of the Judiciary Law of 1789, have we not!" Letter from George W. Wickersham to WHT (Mar. 30, 1928) (Taft papers). Taft wrote back, "It is too lonely to swear alone, and therefore I thank you for keeping me company." Letter from WHT to George W. Wickersham (Mar. 31, 1928) (Taft papers).

375. Letter from WHT to Newton Baker (Apr. 19, 1928) (Taft papers). Van Devanter also sought to arouse political opposition. See Letter from WVD to Walter H. Sanborn, Judge, U.S. 8th Circuit (Apr. 2, 1928) (Van Devanter papers) ("There is real occasion for those who think S. $3151 \ldots$ is not in the public interest to make their opinions known."). Sanborn replied that he would "do whatever I can to prevent its passage, but that is not very much. I will express my opinion about it to those whom I know and will try to get some of them to take hold and argue the matter with the members of Congress that they know. There seems to be a very great desire on the part of some of the Democrats to get rid of the federal courts. When, however, they have elected Al Smith there will be so many Democrats that will want to be federal judges that the tide will turn." Letter from Walter H. Sanborn to WVD (Apr. 5, 1928) (Van Devanter papers). 
his friend Casper Yost, editor of the influential St. Louis GlobeDemocrat, he cautioned that "I am so situated that I can not take a political part, but... I invoke your influence in maintaining the protective power which citizens may secure from the Federal Judiciary in defense of their rights. " ${ }^{376}$ Yost responded by publishing a lively editorial that made plain the political stakes. ${ }^{377}$

That Taft thoroughly understood and was willing to exploit the explosive politics of S. 3151 is evident from a letter he sent to his brother, Henry W. Taft, an influential member of the New York Bar, ${ }^{378}$ urging him to begin a public campaign against the bill:

Now my own judgment about this bill is that if Norris tries to get it through, and is supported by the Democrats, it will prove to be dynamite in the next campaign. It will rouse every negro in the United States, and they cast a great many votes now in the large cities since they have moved north, and when it becomes known to them that they can not resort to the local Federal courts, they will certainly be convinced, as they ought to be, that they are suffering a practical deprivation of their Federal rights and protection. I think you ought to go to the New York Times and to the Tribune and explain the effect of the bill and have editorials printed on the subject. Reference to the negroes will find an echo, and I am quite sure that the Times will feel like warning the Democratic party against any such radical measure. I think you ought to bring it to Hilles' attention and that the opposition to it ought to be made a plank in the National Republican Platform. ${ }^{379}$

376. Letter from WHT to Casper Yost, Editor, St. Louis Globe-Democrat (Apr. 5, 1928) (Taft papers).

377. Federal Courts in Peril, St. Louis Globe-Democrat, Apr. 10, 1928, at 18 ("Apparently a serious movement is on foot to emasculate the federal courts . . . It is high time that Congress and the country were awakening to the perils of this movement, arising from radical elements, and taking measures to suppress it."). See Letter from Casper Yost, Editor, St. Louis Globe-Democrat, to WHT (Apr. 10, 1928) (Taft papers). Taft thanked Yost for the editorial. See Letter from WHT to Casper Yost (Apr. 16, 1928) (Taft papers).

378. See Obituary Record of Graduates of Yale University Deceased During the Year 1945-1946, Bull. Yale U. (Yale U., New Haven, Conn.), Jan. 1, 1947, at 7-8 (noting that Henry Taft was a named partner in the firm of Cadwalader, Wickersham \& Taft).

379. Letter from WHT to Henry W. Taft (Apr. 5, 1928) (Taft papers). Two days later Taft wrote his brother:

What we desire is publicity.... You ... might enlarge on the fact that such a bill as this would destroy the jurisdiction in those cases which McReynolds wrote from Oregon and from Nebraska on the right of the Catholics to maintain separate schools and the right of the Germans to maintain separate education in German. If we can stir up the Germans and the Irish and the negroes to an appreciation of the importance to them of 
When Henry, paralyzed by Charles Evans Hughes's fear that anything "coming from New York" would be dismissed as reflecting "Wall Street interests," 380 proved inept at generating publicity in opposition to the bill, Taft lost patience. ${ }^{381}$ "What I was anxious to do," he explained to his brother, "was to head the movement by an announcement in the New York Times, for there are a great many people who look to the Times as a kind of Bible." ${ }^{382}$ Henry accepted the "rebuke" and promptly contacted Rollo Ogden, editor of The New York Times. ${ }^{383}$ On April 22, the Sunday Times published an editorial strongly opposing the bill..$^{384}$

As Taft well appreciated, the fierce controversy that surrounded S. 3151 simultaneously involved politics and the administration of justice; the two were inseparably combined. ${ }^{385}$ Taft knew that he could

maintaining the jurisdiction of the trial courts, we can make the Democrats a bit chary of burning their fingers with such a revolutionary proposal.

Letter from WHT to Henry W. Taft (Apr. 7, 1928) (Taft papers). Taft added in a postscript, "I am mistaken as to the German language cases. They came from the Supreme Courts of the States. The other came from the U.S. District Court." Id.

380. See Letter from Henry W. Taft to WHT (Apr. 18, 1928) (Taft papers).

381. See Letter from WHT to WVD (Apr. 15, 1928) (Van Devanter papers) ("They seem to be slow in New York to take up the question. My brother Harry is preparing the argument for his editorial friends in New York, but he takes so long that they might pass the bill in the Senate before he gets his articles ready.").

382. Letter from WHT to Henry W. Taft (Apr. 21, 1928) (Van Devanter papers).

383. Letter from Henry W. Taft to WHT (Apr. 20, 1928) (Taft papers). Henry Taft also drafted a long report on behalf of the ABA Committee on Jurisprudence and Law Reform. See Henry W. Taft, An Unwise and Dangerous Measure, 14 A.B.A. J. 266, 266 (1928) (demonstrating how Henry Taft managed to have the ABA Executive Committee go on record against the bill on April 24, 1928). Senator Copeland had the Executive Committee resolution, as well as the report of the Committee on Jurisprudence and Law Reform, reprinted the report in the Congressional Record. See 69 CONG. REC. 8077-80 (1928).

384. See Editorial, Senate and Courts, N.Y. Times, Apr. 22, 1928, § 3, at 4.

385. See Letter from WHT to Robert A. Taft (Apr. 1, 1928) (Taft papers) ("It is a bill that grows out of the Progressive and Democratic union in the Senate .... I should think it doubtful whether it could go through the House as at presently constituted, but if we have a Democratic success in the next election, I think we can count on the probability of the passage of such a bill. They are struggling to save the farmer, but if there is anything that will injure the farmer it will be the rate of interest that will be charged by those who control the capital in the East to be collected from farmers, if eastern capital is not given a place where it can be justly treated."); see also Letter from WHT to Mrs. Frederick J. Manning (Apr. 1, 1928) (Taft papers) ("[The bill would] make the administration of justice more of a farce than it is now, but that is the spirit of the Senate. I am hoping the bill will be killed in the House, but it indicates what would happen if there was a Democratic success in the next election."). 
Taft's deep embroilment in the politics of S. 3151 is evident from the notes of one Henry W. Ward, who wrote a long memorandum summarizing his efforts to mobilize opposition to the bill:

I had a long conference with the Chief Justice. I found him greatly interested in the matter and, needless to say, strongly opposed to the bill. . . . The suggestions of the Chief Justice were as follows:

(a) The bill is of great political importance; so great that if the so-called independent Republicans, notably Senators Borah and Norris, and the Democratic members of the Senate should come out strongly in favor of the bill, it might be advisable to insert a "plank" in the Republican platform at the coming convention putting the party on record as in favor of vesting to the fullest extent in the inferior federal courts the jurisdiction specified in the third Article of the Constitution.

(b) The organized negro vote in the north, a part of which the Democratic party is endeavoring to obtain, would be solidly against any Senator or member of Congress who might put himself on record in favor of the bill... . If they had no recourse to the federal district courts for the assertion of their rights, they would regard themselves as at the mercy of the hostile courts in many of the States, particularly in the South. This political issue appears to be of particular importance with respect to the candidacy of Senator Deneen of Illinois at the present moment.

(c) The effect of the bill upon the western farmers and others throughout the country who are borrowers of capital, would be disastrous.... [T] great bulk of [Eastern] capital has been loaned out in reliance upon the right to resort to the federal courts for collection under the jurisdiction based on diversity of citizenship... The State courts would naturally be biased, in such instances, in favor of the local borrowers ....

(d) [The Chief Justice] ... also expressed entire concurrence in the view that there is no question as to the constitutionality of the elimination of the principal classes and the other classes of jurisdiction now granted by paragraph 1 of Section 24 of the Judicial Code.

The Chief Justice also expressed strong regret that his position deprived him from taking an active part in opposition to the bill, but he did not place any restrictions on my making use of the above suggestions, but, as I understood him, left that matter to my discretion.

On Thursday morning I called again on Senator Wagner told him in a general way the views of the Chief Justice ....

I then called on Senator GOFF, told him of my conference with the Chief Justice ....

Letter from Henry M. Ward to WHT (Apr. 7, 1928) (Taft papers). Although Taft later sought to distance himself from Ward, see Letter from Henry M. Ward to WHT (Apr. 9, 1928) (Taft papers); Letter from WHT to Henry W. Taft (Apr. 10, 1928) (Taft papers); Letter from WHT to WVD (Apr. 17, 1928) (Van Devanter papers), it is plain that Ward's memo accurately reflects the extent to which Taft was fully engaged in an overtly political struggle without wishing to be overtly identified as such. Charles Burlingham considered Ward "a blow-hard and a fakir." Letter from Charles C. Burlingham, President, N.Y.C. Bar Ass'n, to HFS (May 27, 1929) (Stone papers). See Letter from HFS to Charles C. Burlingham (May 28, 1929) (Stone papers). 
not risk overt involvement, yet his name and views figured prominently in the debate. On the floor of the Senate, for example, Senator Royal Copeland of New York, seeking to have the bill remanded to the Committee for hearings, observed that "I am advised by the attorneys who have spoken to me that the Chief Justice of the Supreme Court feels that the bill is not a good bill in some respects." 386

In its editorial, The New York Times specifically referred to Copeland's comment. It remarked that "[i]t is no secret, since the fact was stated in the Senate by Mr. Copeland of New York, that the Chief Justice of the Supreme Court regards some of the features of this bill as most undesirable and harmful." 387 Two weeks later, Senator Duncan Fletcher of Florida had reprinted in the Congressional Record an editorial in the American Bar Association Journal strongly opposing S. 3151, which relied heavily on arguments attributed to Taft, ${ }^{388}$ as well as an editorial from the Florida Times Union that opposed the bill in part on the grounds that "the Chief Justice of the United States Supreme Court ... is reported to have said that this bill has features that can be regarded only as most undesirable and harmful." 389

As a result of the accumulating pressure, Norris was forced to amend his bill to restore federal question jurisdiction. ${ }^{390}$ Taft wrote

386. 69 CONG. REC. 6379 (1928). Norris refused to hold hearings on the bill, saying that "it is a bill on which I think no particular hearings are necessary. It is entirely a legal proposition. ... It is purely a question of practice that the lawyers on the Judiciary Committee understand as well as do other attorneys." Id. at 6378.

387. Senate and Courts, supra note 384.

388. See 69 Cong. ReC. 7421-22 (1928). See Whittling Away at the Federal Tribunals, 14 A.B.A. J. 200, 200-01 (1928) (citing arguments that had made in 1922, the ABA Journal editorial objected to the Bill's repudiation of diversity jurisdiction). See Taft, Possible and Needed Reforms, supra note 101, at 604. In his 1922 speech to the ABA, Taft had conceded that "of course the taking away of fundamental jurisdiction from the federal courts is within the power of Congress, and it is not for me to discuss such a legislative policy." Id. Yet in allowing his views opposing S. 3151 to be publicly known, Taft was exactly discussing legislative policy. Felix Frankfurter later published an article thanking Norris for sponsoring S. 3151 and provoking discussion about the appropriate scope of federal jurisdiction, in which Frankfurter virtually reiterated (without attribution) the negative comments about diversity jurisdiction that Brandeis had sent Frankfurter on May 10, 1928. See supra note 233 and accompanying text; Felix Frankfurter, Distribution of Judicial Power Between United States and State Courts, 13 CoRnell L. Q. 499, 499 n.1, 521-22 (1928).

389. 69 CONG. REC. 7422 (1928).

390. S. 3151, 70th Cong. (1928). See 69 Cong. REC. 8077 (1928). Somehow Taft managed to acquire a copy of a letter sent by Norris to Lewis Gannett of The Nation explaining the proposed change in S. 3151. See Letter from George Norris, Senator, U.S. Senate, to Lewis Gannett (April 28, 1928) ("[The] principal object of 
Henry, "I think Norris has heard a good deal about his proposed changes, and ... he does not find them so easy to push through as he thought he would, in view of the agitation you have all stirred up on the subject." ${ }^{391}$ Norris's revised bill eventually stalled in the Senate. ${ }^{392}$ Yet Taft's intense struggle to defeat it illustrated the uneasy line between disinterested law reform and unabashedly political mobilization. Questions of federal jurisdiction were not merely technical matters that could be delegated to experts; behind them lay large disputes about the regional balance of power within the country. ${ }^{393}$ Overtly addressing these disputes in a legislative context may have been appropriate for an English Lord Chancellor, but for an American judge it could only undermine claims of judicial independence and disinterest.

\section{A DEEP COMMITMENT TO JUDICIAL REFORM}

This is not to say, however, that all of Taft's many interventions to improve the administration of justice-and they were far too frequent to detail here-were equally fraught. Taft was remarkably earnest and responsive in his efforts to reform federal courts. A small but telling example may be found in the history of Public Law No. 69563 , which ended the practice in federal courts of charging defendants with a fee to receive copies of their own indictments. ${ }^{394}$

[S. 3151] . . is to take away the jurisdiction of the Federal Courts in the diversity of citizenship. It is true the bill takes away some other jurisdictions, but the other items we thought were of very little importance. However, there is no objection to amending the bill so as to confine it entirely to diverse citizenship cases."). Taft sent the letter to Van Devanter, dryly commenting: "I send you herewith a copy of a letter written by Norris .... showing how closely he scrutinized the effect of his bill before introducing it." Letter from WHT to WVD (May 4, 1928) (Taft papers).

391. Letter from WHT to Henry W. Taft (May 16, 1928) (Taft papers).

392. See Letter from WHT to Henry W. Taft (July 11, 1924) (Taft papers) ("I haven't a bit of doubt that we could induce Coolidge to veto the Norris bill, but I'm not so sure that we could do so with respect to Smith, although I doubt if he would consent to so radical a measure.").

393. On the intense hostility to federal diversity jurisdiction in southern and western States, see Tony A. Freyer, The Federal Courts, Localism, and the National Economy, 1865-1900, 53 Bus. HIST. REv. 343 (1979); Harry N. Scheiber, Federalism, the Southern Regional Economy, and Public Policy Since 1865, in AMBIVALENT LEGACY: A Legal History OF THE South 69 (David J. Bodenhamer \& James W. Ely, Jr. eds., 1984).

394. Pub. L. No. 69-563, 44 Stat. 1022 (1927). At traditional common law, in the words of Blackstone, "it is usual to deny a copy of the indictment, where there is any ... [f]or it would be a very great discouragement to the public justice of the kingdom, if prosecutors, who had a tolerable ground of suspicion, were liable to be 
In November 1925, Taft received a letter from Joseph Coursey, an unknown lawyer from South Dakota, complaining of "the failure of Federal law ...to provide a copy of the charge to the defendant .... It seems to me it should be almost fundamental that a defendant be given as a matter of right a copy of the accusation against him." 395 Taft asked Coursey whether the charge for the indictment was imposed "by law, or whether it rests in a local rule of practice." 396 Coursey did "not know whether the rule is one of law or practice," but he did "know positively that in this District we can not obtain such a copy without paying for it except in two cases: namely-if the defendant is charged with homicide or will make a pauper showing." ${ }_{397}$

Taft then wrote to Solicitor General William D. Mitchell, asking him to find out "whether it is the practice to furnish defendants with copies of the indictment." ${ }^{398} \mathrm{He}$ enclosed Coursey's letter, adding "I am rather inclined to think that he has a good case, and that the defendant should be given a copy, at the expense of the Government." ${ }^{399}$ Mitchell sent back a detailed, six-page letter, explaining that federal statutes currently required clerks "to charge the accused for copies of the indictments, except in cases involving capital offenses," and that courts deemed the requirements of the Sixth Amendment satisfied "by the formality of reading the indictment to [the defendant] when he is arraigned." 400 Mitchell went on to caution that

if clerks are directed generally to furnish copies of the indictments without charge to the accused, it would greatly increase the volume of work to be performed in the clerk's office, particularly on account of the large number of cases under the National Prohibition Act, and that the clerks' offices are now shorthanded as the result of lack of adequate appropriation. ${ }^{401}$

Not deterred by Mitchell's warning, Taft wrote to Albert Cummins, Chair of the Senate Judiciary Committee, explaining the situation and commenting that "I should think...that the

sued at law whenever their indictments miscarried." 3 BLACKSTONE's COMMENTARIES 126 (W.Y. Birch \& Abraham Small, No. 17 S. Second-Street 1803). See JoHN LANGBEIN, THE ORIGINS OF AdVERSARY CRIMINAL TRIAL 90-92 (2003).

395. Letter from Joseph Coursey to WHT (Nov. 23, 1925) (Taft papers).

396. Letter from WHT to Joseph Coursey (Nov. 28, 1925) (Taft papers).

397. Letter from Joseph Coursey to WHT (Dec. 15, 1925) (Taft papers).

398. Robert Post, Judicial Management and Judicial Disinterest: The Achievements and Perils of Chief Justice William Howard Taft, 23 J. SuP. CT. HisT. 50, 58 (1998).

399. Letter from WHT to William D. Mitchell (Dec. 20, 1925) (Taft papers).

400. Post, supra note 398, at 58.

401. Letter from William D. Mitchell to WHT (Jan. 8, 1926) (Taft papers). 
Government ought to furnish, at its own expense, indictments to defendants." ${ }^{02}$ Taft viewed the question as one of justice, rather than of constitutional compulsion, and he dismissed the potential bureaucratic burden with the observation that clerks could easily type indictments in triplicate. Cummins agreed with Taft's assessment, and he asked Taft to "prepare a Bill relating to furnishing copies of indictments to defendants and send it to me. I will be glad to introduce it." 403

Taft asked Mitchell to draft the bill, which the Solicitor General did, noting that "those in charge of the appropriations for the Department of Justice have estimated that" the bill would "substantially increase the expenses of operating the offices of the clerks of the courts. . . I I have explained, however, that this Bill is not being furnished you as a Department measure, but merely as the result of a personal request for a document to supply Senator Cummins' wants." ${ }^{404}$ Taft forwarded Mitchell's draft to Cummins, who agreed to "introduce the bill and have it referred to the Committee." 405

The result was Public Law No. 69-563, which became law in January 1927.406 The Act was not politically controversial. It exemplified the kind of technical improvement in the administration of justice that Taft sought vigorously to bring within the special province of the Chief Justice. That Taft would take the time to evaluate the unsolicited complaint of an unknown, unsophisticated, provincial lawyer; that he would summon the will and perseverance to remedy that complaint in the face of bureaucratic opposition; and that he could command the personal respect and material assistance of leaders in the executive and legislative branches in this task all reveal a great deal about Taft's success in re-constructing the role of Chief Justice.

\section{LOBBYING FOR JUDICIAL APPOINTMENTS}

Important dimensions of that success, however, were inimitable. Consider Taft's remarkable participation in the matter of judicial appointments. Although American judicial appointments are made by

402. Letter from WHT to Albert B. Cummins, Senator, U.S. Senate (Jan. 11, 1926) (Taft papers).

403. Letter from Albert B. Cummins, Senator, U.S. Senate, to WHT (Jan. 12, 1926) (Taft papers).

404. Letter from William D. Mitchell to WHT (Mar. 3, 1926) (Taft papers).

405. Letter from Albert B. Cummins, Senator, U.S. Senate, to WHT (Mar. 5, 1926) (Taft papers).

406. See 44 Stat. 1022 (1927). 
those with political authority, Taft did his best to use his prestige and contacts as Chief Justice to wrest authority away from the President and Senate. Much has been written about Taft's interventions into the nominations of Justices Butler and Sanford, ${ }^{407}$ but his immense influence reverberated throughout all levels of the federal judiciary in ways that have remained virtually unprecedented.

Even before his appointment as Chief Justice, Taft insistently volunteered "helpful suggestions" to Attorney General Daugherty, "because the Federal Judiciary are like the apple of my eye." 408 Three weeks after his confirmation, he was pleased to confirm that

the Attorney-General assures me that he expects to talk with me all the time about the selection of Judges, and I am very sure, from what he says, that he is determined to make his Administration a memorable one, and one that will be looked upon with approval by the best people. ${ }^{409}$

Senators who saw judicial appointments as political patronage were Taft's perennial enemies. ${ }^{410}$ Because federal judges supervising receiverships could appoint officials who would be entitled to healthy fees, a compliant judge could direct significant financial resources to

407. See Walter Murphy, In His Own Image: Mr. Chief Justice Taft and Supreme Court Appointments, 1961 SuP. CT. REV. 159, 188 (1961) ("[I]f Taft was only partially successful in getting his own candidates on the Court, he was completely successful in keeping out men who he thought would misinterpret the Constitution or increase dissension within the Court."); see generally DAVID J. DANELSKI, A SUPREME COURT JUSTICE IS APPOINTED (1964) (discussing the nomination of Butler); Tennessee Man Named to U.S. Supreme Bench; Judge E.T. Sanford's Appointment Disappoints the Politicians; Senate to Fight Confirmation; Harding Bows to Taft, N.Y. TRIB., Jan. 25, 1923, at 3 (reporting on the nomination of Sanford).

408. Letter from WHT to Harry M. Daugherty, Attorney Gen., U.S. (Apr. 11, 1921) (Taft papers). See Letter from WHT to Harry M. Daugherty (May 2, 1921) (Taft papers) ("II]f you don't mind it, my interests in the Federal Judiciary, where I know something of the situation, makes me anxious to give you the benefit of what I have learned from considerable experience. . . . I am not butting in, but I am only testifying, without any personal slant, and only with a view to helping if I can.").

409. Letter from WHT to Clarence H. Kelsey (July 21, 1921) (Taft papers). To the general public, however, Taft freely dissembled, asserting, "I have nothing to do with the appointment of Judges . . . and do not take any part in their selection. . . . If I were to get into the business of recommending, with all the people whom I know in the United States, I would be swamped and would not have any time for any other work." Letter from WHT to J.G. Butler (Dec. 16, 1921) (Taft papers). See Letter from WHT to Emily R. Collins (Dec. 13, 1921) (Taft papers).

410. See Letter from WHT to Charles D. Hilles (Jan. 20, 1923) (Taft papers) ("Why is it that a Judge who is best fitted never strikes the ordinary politician as the man to take?"). 
a Senator's followers. ${ }^{411}$ Taft pressed Daugherty to write President Warren G. Harding that "Senators and Representatives and political influence generally should be given to understand that they must not expect, as a matter of patronage, to dominate or dictate ... appointments." ${ }^{412}$ Matters came to a head when the Act of September 14, 1922 suddenly created twenty-four new district judgeships (and one circuit judgeship). ${ }^{413}$

Taft wrote to Attorney General Daugherty with the presumption and easy intimacy of a former political confederate:

I presume the bill for additional judges will pass. I am greatly concerned over the personnel of those judges. You and the Administration will be on trial in respect to the men who are selected. It will cost a great deal of effort to resist the rapacious demands of Senators and Congressmen for particular favorites, who are not fitted, many of them, to be judges. In the district of New York, I understand that Koenig and Ward and somebody else have agreed as to the slate for the vacancy and for the two other judges, and that Siegel is to be included in them. Now there is a typical instance. If the Administration yields to that, it will stamp the whole panel of judges to be selected. I beg of you to follow the advice of the New York Bar Association, who have no motive except that of getting the best judges, and in your own interest and in the interest of the party, and in the interest of the country, I urge that you and the President insist that these judges shall be selected not by agreement between political quantities but on their merits. . . My dear Harry, you want to refute your enemies, and you are going to do it, but one of the chief opportunities is through the selection of the highest standard of men for these twenty-five additional judges. I hope you will appoint some Democrats, in spite of the partisan bitterness of the attacks on you. ... I am deeply concerned in your welfare and in your success, and in that of the Administration, and what I have written is out of a full

411. Taft was appalled, for example, to hear a "prominent lawyer from Kansas City" estimate that a "[j]udge has patronage in Kansas City worth $\$ 80,000$ a year. Think of estimating the importance of a Federal Judge by the amount of receiverships or other things that he may have to fill." Letter from WHT to Robert A. Taft (Mar. 15, 1925) (Taft papers).

412. Letter from Harry M. Daugherty, Attorney Gen., U.S., to Warren G. Harding, President, U.S. (Apr. 8, 1922) (Harding papers).

413. In August 1921, Taft wrote Senator Cummins that he was pleased that Harding could "delay appointments until the Senate [met] again in December, and thus the question of appointments w[ould] not be complicated by the election. It [wa]s a most critical and delicate duty that the President w[ould] have to perform in selecting all at once so many permanent judges. He w[ould] need a full three months to decide upon all the judges." Letter from WHT to Albert B. Cummins, Senator, U.S. Senate (Aug. 21, 1922) (Taft papers). 
heart and with a fairly competent knowledge and experience in the particular field to which I am referring. ${ }^{414}$

Taft professed himself satisfied with Daugherty's stalwart loyalty in the matter of judicial appointments. ${ }^{415}$ Daugherty's "relations with me have been most cordial and intimate," Taft wrote to his nephew, "and he has consulted me a great deal about judicial appointments, which with me are everything now, and has manifested a desire and proved its genuine existence by his care with respect to such matters." 416

At least during the Harding years, Taft received the full support of the executive branch as he fought with Senators to control the flow of judicial appointments. So, for example, Harding wrote Taft:

I had understood that there was some criticism of your activity in discussing the availability of candidates for judicial appointment. My impression was that the criticism grew out of an interview with Senator Spencer relating to the qualifications of a candidate for appointment in St. Louis. The matter can be of no embarrassment to me. I am always happy to welcome

414. Letter from WHT to Harry M. Daugherty, Attorney Gen., U.S. (June 5, 1922) (Van Devanter papers). To the extent that Democrats shared his own basic constitutional convictions, Taft was always concerned to make the federal judiciary bipartisan. See Letter from WHT to Hatton W. Sumners, Congressman, U.S. House of Representatives (Jan. 15, 1927) (Taft papers). This was especially true in the South. See Letter from WHT to Ben C. Dawkins, Judge, U.S. Dist. W. La. (Mar. 31, 1925) (Taft papers) ("I am intensely interested in the success of the Federal Judiciary, and am delighted to have it a non-partisan body - in the South particularly."). As Taft said, "It was part of my purpose, when President, to appoint men to the Federal Bench in the South who would convince the people of that section that the Court was not an alien court, but one in which justice could be found for the citizens of the South and the citizens of the North." Letter from WHT to William H. Barrett, Judge, U.S. Dist. S. Ga. (Oct. 12, 1922) (Taft papers).

415. It is for this reason that Taft struggled to stand by Daugherty in 1924 when scandal engulfed the Attorney General's office. "He has stood up in the matter of Judges," Taft wrote his son, "which after all is the chief and most responsible thing he had to do, and he has secured on the whole, against the vicious system of Senatorial selection of candidates for political purposes, a good list of Judges. But for him Harding would have made a wreck of it, I fear, because he was not a lawyer and did not appreciate the importance of the selections." Letter from WHT to Robert A. Taft (Jan. 27, 1924) (Taft papers). See Letter from WHT to Horace D. Taft (Feb. 29, 1924) (Taft papers).

416. Letter from WHT to Hulbert Taft (Jan. 7, 1923) (Taft papers). See Letter from WHT to A.R. Kimbell (Feb. 8, 1923) (Taft papers) ("I have so much to do in trying to influence the President in respect to judicial appointments that I am afraid I can not do much in the Civil Service business."). But see Presidential Memorandum (May 1, 1923) (Harding papers) (noting that " $[\mathrm{t}]$ he Chief Justice warns against Henry Lincoln Johnson's recommendation for Superintendent" at the Veterans Hospital at Tuskegee). 
suggestions especially from those who are in a position to know something concerning the matter. ${ }^{417}$

Taft applied the same criteria for lower court judges as he did to Supreme Court colleagues: they had to display good character and conservative constitutional commitments. ${ }^{418}$ So, for example, Taft

417. Letter from Warren G. Harding, President, U.S., to WHT (Jan. 15, 1923) (Taft papers). See Letter from WHT to Charles D. Hilles, Fin. Comm. Chair, Republican Nat'l Comm. (Jan. 17, 1923) (Taft papers); Letter from Charles D. Hilles to WHT (Jan. 18, 1923) (Taft papers) ("I don't want to irritate you by seeming to assume to be the guardian of your person, but I think you are working too hard. It seems to me unfortunate that at a time when a vast number of most important questions are before your Court for determination that you should have to go so thoroughly into the details of the qualifications of the horde of men who are seeking appointment as District Judges throughout the United States. I can well understand that the President, feeling a sense of insecurity in the selection of judges because he is not himself a lawyer, and having made the discovery that the so-called leading lights of the profession are not unselfish in putting forward certain candidates, leans heavily upon you because he knows that you have an eye single to the very best results for the Republic."). At the time, Hilles was the Finance Committee Chair of the Republican National Committee. Taft replied to Hilles: "Don't be troubled about my labors in respect to Judges - it's a labor of love. It isn't true that Harding imposes the burden on me. It isn't true that he has asked me for my judgment in respect to anybody; but I have tendered it and then he has expressed his satisfaction that I had done so. But he has been very careful never to be affirmative in his request for my advice. It has been my sense of duty that has carried me into the matter." Letter from WHT to Charles D. Hilles (Jan. 20, 1923) (Taft papers). Taft nevertheless remained concerned that Harding had "grown a little sensitive about the constant reports that the matter is in a way delegated to me." Letter from WHT to Edward Colston (Feb. 21, 1923) (Taft papers).

418. A commitment to judicial efficiency apparently led Taft to make a conspicuous exception for Learned Hand. Six months after vetoing Hand for a possible appointment to the Supreme Court, Taft would write a friend that he and Learned Hand had "become warm friends and are greatly interested in working together to render the administration of justice more effective. While he and I differ on some things, he is a very hard worker and a very effective Judge. We are trying to get rid of the enormous mass of arrears that have accumulated in his district." Letter from WHT to Gertrude Ely (May 2, 1923) (Taft papers). The following year Taft urged Coolidge to promote Hand to the Second Circuit, writing to Attorney General Harlan Stone:

I note that we have lost Mayer from the Circuit Bench in the Second Circuit. ... It seems to me that where you have good District Judges, the wisest course is to promote one of them. Learned Hand I think would probably be the best man to take. He is the oldest in commission of the District Judges and is a fine lawyer, and in many ways a brilliant Judge. I appointed him District Judge, and I confess that I was greatly disappointed when he lost his head over Roosevelt, to such an extent as to enter into politics while on the Bench, and I think he ran for the office of the Court of Appeals on the Progressive ticket. I was very indignant at him for this, because it seems to me that a man who is on the Bench should consider 
engaged in a protracted and bitter battle with Senator Selden Palmer Spencer of Missouri over the appointment to the district court of Spencer's former law partner Vital W. Garesche, whom Taft characterized as "a gangster ... who drinks." 119 Taft believed that Spencer was "threatening... [to] go Bolshevik unless Garesche is appointed, and of course that would make the loss of one vote on critical issues.... We must uphold the Federal Judiciary-it is our bulwark - and to have such a man fastened on us would be most distressing."

himself cloistered from politics, but I have come to know Hand better since, and while I think he made an ass of himself at that time, I believe that he has worked hard, has done very good work, and would be a very able member of that Court of Appeals.

Letter from WHT to HFS (Aug. 1, 1924) (Taft papers). Stone replied:

I have gradually been coming to the conclusions which you express with reference to Judge Learned hand. He is somewhat radical and erratic in his political thinking, but has had a long and satisfactory service as a Judge and practically all the letters I get from members of the Bar whose opinions I value indicate a very general desire that he should be promoted.

Letter from HFS to WHT (Aug. 4, 1924) (Taft papers).

419. Letter from WHT to Charles D. Hilles (Jan. 17, 1923) (Taft papers).

420. Letter from WHT to Festus J. Wade (Feb. 12, 1923) (Taft papers) ("That shows the kind of man Spencer is . . . I am the more exasperated because he is a Yale man and makes broad his claims on that subject."). The press was well aware of Taft's opposition to Garesche. See, e.g., Spencer Fails to Weaken Opposition to Garesche, St. Louis Post-Dispatch, Jan. 4, 1923, at 4; Babler Takes Hand in Contest for Judgeship, St. Louis Post-DisPatch, Dec. 2, 1923, at 8. After Harding's death, Taft continued to battle against Garesche with Coolidge: "I don't know that Coolidge will follow my advice, but I count myself fortunate that I took time by the forelock to speak to Coolidge about the matter. I think that Coolidge will send for the record and examine it, and, if he does, I think he will find some facts there that will shake a man who has Massachusetts or Vermont ideals of what a Judge should be." Letter from WHT to Gus Karger (Sept. 14, 1923) (Taft papers). See Letter from WHT to Calvin Coolidge, President, U.S. (Oct. 6, 1923) (Taft papers); Letter from Calvin Coolidge to WHT (Oct. 8, 1923) (Taft papers); Letter from WHT to Calvin Coolidge (Dec. 23, 1923) (Taft papers). In November 1923, Taft summarized the struggle over Garesche in this way:

I have been engaged in fighting [Garesche] tooth and toe nail. Spencer came to me and tried to induce me to withdraw my opposition, and I flatly declined to do so.... Spencer got himself appointed on the committee to attend Harding's funeral by the President of the Senate, in order that he might go out with President Coolidge on his car for the purpose of securing Coolidge's promise to appoint Garesche. By good luck I went on the same car, and before I left Washington was able to put the case to Coolidge in such a way that I think he is convinced — indeed he has told me so. . . There is a great deal of discussion of the power of the Supreme Court and the way in which it is exercised, but to one who lives in Washington the real 
toward the Constitution and accepting its present construction and the accepted jurisdiction of the Federal Judiciary should all be considered before" giving "serious thought" to a nomination. ${ }^{421}$

After Harding's death, Taft noted with approval that Coolidge "has manifested a disposition to appoint good men to the Bench, and I hope I can exercise some influence in this way." 422 Within two months, Taft was explaining to Coolidge the situation in the district court of the Eastern District of South Carolina. "I hope you will permit me to write you on questions of this sort," he said, "where I have any

objectionable exercise of personal power is that of small-minded Senators over Federal appointments in their States.

Letter from WHT to Fred T. Murphy (Nov. 30, 1923) (Taft papers).

The contest over Garesche's appointment lasted until January 1924, when Coolidge at last nominated Charles B. Davis. The difficulty was that Coolidge needed the votes of every regular Republican Senator to sustain his policies, and so was reluctant to alienate Spencer. "I saw the President the other morning," Taft wrote his brother. "He told me that he has not as yet succeeded in committing enough Senators to sustain his veto of the bonus bill, but he thought everything looked encouraging. . . . He is in a situation now where he needs Senatorial votes, and I think, from what he said, he has deliberately made up his mind he will not make two or three judicial appointments which he knows he ought not to make. He will not make any appointments at all until after the crisis. He says it is a great deal better to have no Judge than to have a bad Judge. Of course there is still another alternative and that is to appoint a good Judge, but the appointment of anybody but a bad Judge at this time I presume he thinks would alienate the votes which he hopes to get to sustain his policy of anti-bonus and tax reduction. You thus have a problem of political ethics which practical men meet as he is meeting it." Letter from WHT to Horace D. Taft (Jan. 12, 1924) (Taft papers).

421. Letter from WHT to John G. Sargent, Attorney Gen., U.S. (Nov. 19, 1927) (Taft papers). Van Devanter had a similar perspective. See Letter from WVD to Robert E. Lewis, Judge, U.S. Tenth Cir. (Mar. 28, 1929) (Van Devanter papers) ("If I questioned his fitness in any particular it was along the lines of good balance and stability. In the single argument which I heard him make he manifested a little inclination to warp the Constitution and the law to give effect to what he conceived in the particular case would be an onward and upward view. I noticed that several of my associates understood his argument in the same way. Of course a single argument is not an adequate or a fair test. But the one which he made left in my mind a query as to whether his tendency is towards a balanced judgement and stability. I regard these as essential elements to the proper exercise of the judicial function."). On Daugherty's view of the criteria for federal judges, see Daugherty, Congested Dockets in the Federal Courts Menace to Justice Says Attorney General, supra note 113, at 611 ("I want to say here that no man, no matter what his ability may be, will ever be endorsed by the Attorney General unless he is 100 per cent American in every shape and form. For the federal judiciary is the backbone of our government, and in these times of discontent and vicious radicalism, these judges must stand between the Constitution and the blind gropings of those who are swayed by violent and unscrupulous leaders.").

422. Letter from WHT to Horace D. Taft (Sept. 29, 1923) (Taft papers). 
means of information, because of my intense interest in securing a good Judiciary, and my earnest desire to help you in your manifold labors where I think I can be of assistance in a field like this one." ${ }_{423}$ "I value your interest and friendly suggestions always," Coolidge replied. ${ }^{424}$ "Be sure to let me know when anything occurs to you. . . I I am glad to have your judgment." 425 After Daugherty stepped down in scandal, Taft continued to recommend judicial candidates to Attorney General Harlan Fiske Stone, who was "very glad to receive" 426 Taft's advice and "very anxious to help." 427 Taft viewed Stone as "very satisfactory" on the question of judicial appointments. ${ }^{428}$

423. Letter from WHT to Calvin Coolidge, President, U.S. (Oct. 17, 1923) (Taft papers).

424. Letter from Calvin Coolidge, President, U.S., to WHT (Oct. 17, 1923) (Taft papers).

425. Id.

426. Letter from WHT to HFS (Apr. 22, 1924) (Taft papers); HFS to WHT (Apr. 24, 1924) (Taft papers). Taft's letter to Stone in part concerned the unfitness of the Chief Justice of Kentucky for a position on the Sixth Circuit. Taft was not above manipulating the Act of September 14, 1922, in order to further his designs. Thus, he wrote his wife:

Dick Ernst came to see me to-day. He is very much troubled because of the earnest candidacy of a very unfit man to become United States Circuit Judge in the Sixth Circuit. . . . I told Dick to tell the President that if he would keep the matter open until next fall, I would agree to keep a Judge in the Sixth Circuit who could do the work.

Letter from WHT to Helen Herron Taft (Apr. 25, 1924) (Taft papers). Taft was explicit to Coolidge about the potential manipulation of assignment authority. See Letter from WHT to Calvin Coolidge, President, U.S. (June 4, 1924) (Taft papers); Letter from Calvin Coolidge to WHT (June 4, 1924) (Taft papers).

427. Letter from WHT to A.C. Denison (May 8, 1924) (Taft papers). See Letter from WHT to Alex P. Humphrey (May 8, 1924) (Taft papers); Letter from WHT to HFS (June 7, 1924) (Taft papers).

428. Letter from WHT to Charles D. Hilles, Fin. Comm. Chair, Republican Nat'l Comm. (Dec. 3, 1924) (Taft papers). Taft wrote his daughter, "I am very much concerned with the appointment of Judges. There are a good many vacancies. The salaries are so low that it much reduces the number of eligible and invites the candidacy of men who are failures in the profession and who never would be thought of but for the lack of real timber. The vicious disposition of the Senators to use appointments to the Bench for their own political purposes is a thing that the President needs the utmost courage to resist, and somebody has to keep him advised. The present Attorney General is all right, and indeed Daugherty was on this point, but the Senators are persistent and gore the President with their unpatriotic attacks." Letter from WHT to Mrs. Frederick J. Manning (Nov. 30, 1924) (Taft papers). See Letter from WHT to Robert A. Taft (Dec. 14, 1924) (Taft papers) ("The life of the Attorney General in trying to help the judiciary is a dreadful one, and he has my utmost sympathy."); Letter from WHT to Walter H. Sanborn (Feb. 28, 1925) (Taft papers) (noting after Stone's confirmation that he would talk to Charles B. Warren, the likely new Attorney General, about a judicial appointment to the Eighth Circuit, but that he 
After Stone left the Administration and joined the Court, however, Taft perceived Coolidge as "rather disposed to consult Stone," so that Taft's hopes of continuing to shape appointments were somewhat mediated by Stone's interventions. ${ }^{429}$ Taft appreciated that his own influence was waning. In part this was because in the new 69th Congress, which began work in March 1925, a "union of the Democrats with the radical Republicans" 430 undercut Coolidge's margin in the Senate, which twice defeated Coolidge's nomination of Charles B. Warren to replace Stone as Attorney General. ${ }^{431}$ As a result, Coolidge became "loath to turn a Senator down." ${ }^{432}$ Coolidge was

\begin{abstract}
very anxious to preserve the good will of Republican Senators, a good many of whom are quite willing and especially anxious to use the judicial patronage of the President to favor their particular local plans. ... I have tried in the past to influence the President with reference to judicial appointments when I thought an opportunity existed to secure good men, but I think the President thinks that I am too insistent on having good men and am not sufficiently sympathetic with his trials with Senators, and I am going to keep out of the judicial selections hereafter. It takes a great deal of time to run around and it takes me from other work that I need to do, and I don't think I could make my voice prevail against a Senator . . . ${ }^{433}$
\end{abstract}

was "not so convinced that [Warren] would be as likely to listen to me as would the retiring Attorney General, who comes to us Monday").

429. Letter from WHT to Robert A. Taft (Mar. 15, 1925) (Taft papers) "At least Van Devanter and Butler are invoking his aid," Taft reported to his son. See Letter from WHT to HFS (Nov. 13, 1925) (Taft papers); Letter from WHT to Augustus N. Hand, Judge, S.D.N.Y. (Nov. 14, 1925) (Taft papers) ("I am going to turn the matter over to Justice Stone."). Stone himself affirmed that "[w]hile I take no active part in the selection of Judges, I am anxious to see good Judges appointed, and I am often consulted." Letter from HFS to Charles C. Burlingham (Oct. 31, 1925) (Stone papers).

430. Letter from WHT to Robert A. Taft (Mar. 15, 1925) (Taft papers).

431. See, e.g., Amber Phillips, That Time a Vice President Almost Cast a Historic Tiebreaking Vote But Was Derailed by a Nap, WASH. PosT (Feb. 7, 2017), https://www.washingtonpost.com/news/the-fix/wp/2017/02/07/that-time-a-vicepresident-almost-cast-a-historic-tiebreaking-vote-but-was-derailed-by-a-nap/ [https://perma.cc/WRL3-B3T9] (noting that, in the first instance, Warren was defeated by a margin of one vote when Vice President Dawes famously failed to show up to cast the deciding ballot in a 50-50 tie).

432. Letter from WHT to Horace D. Taft (Mar. 14, 1925) (Taft papers).

433. Letter from WHT to Robert A. Taft (Mar. 15, 1925) (Taft papers) ("People don't understand the outrage of the Senatorial inference in judicial appointments and they don't understand how strong the leverage that a Republican Senator has in these days when so much depends, for the comfort of the President, and for his achieving anything of his broad purposes, upon the vote of a twopenny small-minded United States Senate, and I don't think there are many who don't come within that description."). 
After the 69th Congress, therefore, Taft resigned himself to the fact that Coolidge was "much less interested than he was at first" in Taft's advice about judicial appointments. ${ }^{434}$ Taft complained to his son that

[t]he President has not consulted me nearly so much about Judges as he did. When Stone was Attorney General he was anxious to know what I knew. I warned the President about Charley Warren, and since that time [he] has not been anxious to have my advice, so I don't tender it. He has made a very poor appointment in the Southern District of California. ${ }^{435}$

"The President," said Taft, "looks askance at my non-partisan feeling about Judges." 436

After Warren's rejection, Coolidge nominated his childhood friend John G. Sargent to be Attorney General. In Taft's eyes, it was "painful ... how awkward and clumsy he is. He is honest, but that is about all, and I feel at times like going to the President and telling him so.... The Department of Justice as at present organized can not be trusted at all to make any good selections for Judges or District Attorneys or Marshals." ${ }^{37}$ Sargent was "a good man, but he is stupid

434. Letter from WHT to W.W. Chapin (Apr. 16, 1925) (Taft papers). "I am not called in now in respect to judicial appointments. I think my constant interest and my attitude of opposition to Senators have tired the appointing power." Letter from WHT to Charles D. Hilles, Vice Chair, Republican Nat'l Comm. (Apr. 24, 1925) (Taft papers). See Letter from WHT to Henry Lippitt (Apr. 24, 1925) (Taft papers). Taft's perception that Coolidge became more inclined to defer to Senatorial courtesy was later confirmed by Coolidge's secretary, Everett Sanders, who observed that Coolidge "became convinced that it was useless to send to the Senate a nomination for an appointment to the Bench in any state where the Senators would make real objection." William A. White, A Puritan in Babylon: The Story of Calvin Coolidge 28687 n.14 (1938). White summarizes the situation: "So the President let the Senators name the judges, the judges let the Senators have a hand in naming federal receivers whose clerks, attorneys and hangers-on were Senatorial claquers, and the President had his way with the more regular and subservient Republicans in Congress. Chief Justice Taft who had returned to earth from the Heaven of judicial isolation had to see his ideal of a hightoned judiciary wither and fade." Id. at 424. See Donald R. MCCOY, CALvin CoOlidge: The Quiet PResident 172-73 (1967).

435. Letter from WHT to Robert A. Taft (May 3, 1925) (Taft papers). At about this time, Brandeis wrote Frankfurter that "[w]e are beginning to reap a fine harvest in Federal Judges. Perhaps it may help in the 'back to the states' movement-however illogically." Letter from LDB to FF (June 20, 1925), in BRANDEIS FRANKFURTER CORRESPONDENCE, supra note 41, at 205. See Letter from LDB to FF (Dec. 25, 1927), in BRANDEIS FRANKFURTER CORRESPONDENCE, supra note 41, at 315 ("C.C. is doing quite as badly as Harding in the gradual process of undermining the Federal Courts. High authorities within my ken are very sad about it.").

436. Letter from WHT to Thomas W. Shelton (Apr. 6, 1927) (Taft papers).

437. Letter from WHT to Robert A. Taft (Feb. 7, 1926) (Taft papers). 
and slow and utterly lacking in methods which will secure good appointees for the important places that he has to fill upon the recommendation to President." 438

Even as his public reputation for influence grew, ${ }^{439}$ Taft complained that Coolidge "hasn't good judgment" in regard to appointments and "yields too much to Senators and Congressmen in their demands for patronage in respect to positions as to which he should feel independent." 440 "I don't have any influence at all in the selection of Judges. It has passed to political control, largely through the Senators. A man who insists on the real qualifications as a Judge in the candidate is not one who seems to be successful these days in

438. Letter from WHT to Charles P. Taft II (Feb. 14, 1926) (Taft papers). See Letter from WHT to Albert S. Ingalls (Aug. 20, 1928) ("If Coolidge had any independence on the subject of judicial appointments, I would hope to have some influence, but I haven't any. It is discouraging to one interested in maintaining the high personnel of the Federal inferior judges. It may be as much due to the inefficiency of the Attorney General as to any other cause."). Stone was also inclined to blame the poor quality of appointments on his successor as Attorney General rather than on President Coolidge. See Letter from HFS to Charles C. Burlingham (Dec. 30, 1926) (Stone papers).

439. See, e.g., Alling May Be Chosen U.S. Judge, HartFord Courant, July 3, 1927, at 1 ("No matter how acceptable a candidate is to State leaders, it is said the candidate must meet the test of whether he is acceptable to Chief Justice Taft. President Coolidge, it is known, is governed largely by the advice of the Chief Justice in making his appointments to the Federal bench."); $c f$. Letter from WHT to Horace D. Taft (Oct. 21, 1927) (Taft papers) ("I shall go and see the President and tell him that Alling isn't up to the mark, but I don't know that it will do any good, with a Senator on the other side.").

440. Letter from WHT to Charles D. Hilles, Vice Chair, Republican Nat'l Comm. (July 7, 1926) (Taft papers). Taft's correspondence betrays annoyance that the Administration had selected a judge to fill the new district in Georgia that had been engineered by Taft himself through a recommendation of the Judicial Conference. See Letter from WHT to Charles D. Hilles (June 10, 1926) (Taft papers) ("I haven't been consulted at all about the Federal Judgeship in Georgia. I got the bill through, but this present Administration makes its selections in a very curious way, and I have very little to do with it."); Letter from WHT to Clark Howell, Editor, The Atlanta Constitution (Mar. 25, 1925) (Taft papers) ("Could you not call attention to the deplorable condition of arrears in the Northern District of Georgia and the absolute necessity for added force? Could you not interest your brother and the other leading members of the Bar to organize a movement to insist that such a place should be created? The Senior Circuit Judges, who meet in Conference under my Presidency on the $9^{\text {th }}$ of June, will be certain to readopt a resolution adopted some time ago, urging the new Congress to provide another Judge. These things are accomplished by taking them up in time. I shall help them as much as I can when they come here by personally addressing both committees on the subject."). 
any recommendation." ${ }_{441}$ Taft began to receive dismal notes of consolation: "I presume you are sick of trying to get good Judges appointed and having your efforts ignored." 442

Taft would occasionally get the bit between his teeth and push hard for particular candidates, as for example to ensure that Augustus

441. Letter from WHT to John C. Vivian, Attorney, Jefferson Cty. (May 27, 1928) (Taft papers). Taft was thrown to the outside of the nomination process even in his home state of Ohio. See Letter from WHT to David S. Ingalls, Member, Ohio House of Representatives (Aug. 10, 1928) (Taft papers) ("I don't expect to have anything to do with the appointment. The Republican Senator who is running for nomination, Senator Fess, is quite insistent on controlling the appointments of Judges in the State, with a view of keeping his fences mended. I haven't patience with such a motive for the selecting of Judges. The President hearkens to Senatorial recommendations, and the Attorney General offers no objection of any real substance. I would intervene with recommendations if I thought they would do any good, but I am quite sure they will not."). See Letter from WHT to Charles P. Taft II (Aug. 11, 1928) (Taft papers) ("They pay no attention to me at the White House, though of course the President gives me a respectable hearing, but I go and make my statement, and nothing happens.”); Letter from WHT to A.I. Vorys (Sept. 19, 1928) (Taft papers) ("If we could get good judges in Ohio ... I would thank God. But I shall attribute it to Him and neither to the Fess nor to the President, because the last thing that either makes as a basis for the selection is the qualification and fitness of the appointee. They come in after the political needs of Fess are satisfied. I find great difficulty in being patient with either of them. I don't think my recommendations amount to anything with either, but such as they are I shall give them.").

442. Letter from Augustus N. Hand, Judge, S.D.N.Y., to WHT (Mar. 23, 1926) (Taft papers). This was apparently also the experience of other Justices on the Court. So, for example, Van Devanter wrote to his friend Judge John C. Pollock in 1929:

Some times the Circuit Justice is consulted respecting the appointments of circuit judges and district judges within his circuit. When I came here that was the general rule. Of late years the rule has not been followed. My associates so say and my experience is the same.

The judicial nominations made by President Coolidge near the close of his administration were made without any consultation with any of us. Some of the nominations were very good and others not so good.

Letter from WVD to John C. Pollock, Judge, U.S. Dist. Kan. (Mar. 21, 1929) (Van Devanter papers). Stone apparently had the same experience, even though he was in 1929 by far the most politically connected Justice. See Letter from HFS to Learned Hand, Judge, U.S. Second Cir. (Mar. 5, 1929) (Stone papers). 
Hand $^{443}$ and Yale Law School Dean Thomas W. Swan ${ }^{444}$ were appointed to the Second Circuit. Taft took some comfort from the fact

443. On Taft's engagement with Hand's appointment, see, e.g., Letter from WHT to George Zabriskie (Sept. 7, 1926) (Taft papers) ("I expect to do all I can for Augustus Hand to be a Circuit Judge ... . He has earned it, and, as you know, I have but little patience with the question of a man's political past as a reason for appointment or non-appointment to a place on the bench that he deserves and is able to fill as well as Judge Hand could fill this."); Letter from WHT to Elihu Root (Sep. 17, 1926) (Taft papers) ("Hand is a Democrat, but he is a first class Judge. . . [H]e is not perhaps quite so brilliant as Learned Hand, but I would rather trust his judgment."); Letter from WHT to Learned Hand (Sept. 28, 1926) (Taft papers); Letter from WHT to Learned Hand (Nov. 11, 1926) (Taft papers); Letter from WHT to Augustus N. Hand, Judge, S.D.N.Y. (Jan. 5, 1927) (Taft papers); Letter from WHT to Charles Evans Hughes (Apr. 26, 1927) (Taft papers) ("He is the kind of a safe Judge that is needed on that Bench. Learned Hand is brilliant but sometimes erratic . . . . If we are to make the Bench a place for the best men, the appointing power should recognize the obligation to promote those who have deserved well and have proven their capacity."); Letter from WHT to George W. Wickersham (Apr. 26, 1927) (Taft papers) ("He is needed on that bench to mix his common sense with Learned Hand's brilliancy."); Letter from WHT to Learned Hand (Apr. 27, 1927) (Taft papers) ("I have been doing what I could to bring about the selection of Gus Hand as your colleague. I wrote the President. I stirred up Stone and he went to see the President. I wrote George Wickersham, and he has written a letter. I wrote Hughes and asked him to write a letter, and I wrote to Hilles and asked him to write a letter. The latter was for the purpose of taking care of the political end. Stone had an interview with the President yesterday ....”); Letter from WHT to Learned Hand (Apr. 30, 1927) (Taft papers); Letter from WHT to Learned Hand (May 3, 1927) (Taft papers) ("If we win for Gus, it will be a great triumph - that is the truth of it."); Letter from WHT to Augustus N. Hand (May 6, 1927) (Taft papers) ("I must face the fact that it is more important what Hilles thinks in this matter than what I think."); Letter from WHT to Augustus N. Hand (May 22, 1927) (Taft papers) ("I felicitate you on the prospect of a long, useful, judicial life, and I don't think that one can lead any life that can be more satisfactory than it."); Letter from Learned Hand to WHT (May 24, 1927) (Taft papers) ("Your interest was I believe a very potent cause of the result."). Stone was also very much involved in Hand's appointment. See, e.g., Letter from Learned Hand to HFS (May 24, 1927) (Stone papers) ("Thanks for your share in it, which I suspect was very important.”); Letter from HFS to Learned Hand (May 25, 1927) (Stone papers) ("I don't suppose I had much to do with it, but I allowed my views on the subject to be known for what they were worth."); Letter from HFS to Learned Hand (Nov. 16, 1926) (Stone papers); Letter from HFS to Charles C. Burlingham (Nov. 19, 1926) (Stone papers); Letter from HFS to Learned Hand (Nov. 19, 1926) (Stone papers).

444. On Taft's involvement with Swan's appointment, see, e.g., Letter from WHT to Learned Hand (Nov. 16, 1926) (Taft papers) ("I am inclined to press Swan for Rogers' place and then have the President put up Gus Hand for the new Circuit Judgeship that I hope we can get."); Letter from Calvin Coolidge, President, U.S., to WHT (Nov. 30, 1926) (Taft papers) ("I shall bear in mind all of the fine things you say of Dean Swan. It was a genuine pleasure to see you looking so well.”); Letter from Thomas W. Swan to WHT (Nov. 30, 1926) (Taft papers) ("[T]hat you desire my 
"that we have succeeded in getting some good ones from Calvin after a while." 445 But for the most part, as Taft wrote Senior Circuit Judge Arthur C. Denison, "It seems now that we have got to rejoice if we don't have a bad appointment. We can't aspire to good ones." 446

appointment as a Circuit Judge I deem as great an honor as would be the appointment itself .... Your suggestion of Mr. Justice Van Devanter as an honorary degree candidate fills me with enthusiasm. I shall try to get the Law School Faculty behind the nomination and hope the corporation will confer the degree at the coming commencement."); Letter from WHT to John G. Sargent, Attorney Gen., U.S. (Nov. 30, 1926). Stone also supported Swan's appointment. See Letter from HFS to Thomas W. Swan (Jan. 6, 1927) (Stone papers) ("I am much gratified at your appointment and no the less so because I had a modest part in it.").

445. Letter from WHT to Learned Hand (May 25, 1927) (Taft papers). See Letter from WHT to Robert A. Taft (June 5, 1927) (Taft papers) ("My only criticism of [Coolidge] would be his selection of men, because I don't think he has good judgment in that regard, and he hasn't done as well by us in the selection of Judges as he might, although he has appointed some good ones. Still he would make a great deal better President than Al Smith and his continuance in office would give a stability to our government and the progress of the country that would be worth a great deal.").

446. Letter from WHT to Arthur C. Denison, Judge, U.S. Sixth Cir. (July 21, 1927) (Taft papers). At about this time, Van Devanter wrote his friend George B. Rose about the proper way to shape an appointment to the federal bench:

I do not assume to have any power to control or influence the appointment of District Judges in our circuit but I am deeply interested in the maintenance of right standards and when my recommendation is solicited, as it occasionally is, I endeavor to act impartially and for the good of the service. My suggestion is that you are going about it in the wrong way. The Attorney General will wish to do the right thing but he knows nothings about the Arkansas bar and must depend on recommendations made by others. At times a representative is sent out to make inquiries but the Department has no one to send out who is really fitted for the purpose. At times (not recently) the reports of such investigations have been submitted to me, and while I regarded the reports as well intended they appeared to me quite unsatisfactory. The better way is for leading members of the bar to get together, canvass the situation candidly and impartially and select a committee to present one, two or three names of men fitted for the position. Then get endorsements, if it reasonably can be done, by political representatives in the community, such as party committeemen, and also endorsements by senators and representatives. A bar committee rightly chosen and acting wisely can go far towards accomplishing all that is needed in this line. The committee could come to Washington and could make a presentation of the matter to the Attorney General and if need be to the President. ... .

I may or may not be asked about the matter. If asked I must necessarily be informed else I could not be helpful and could not speak. I have some acquaintance with your bar but it is not general and may be inadequate. If there be aspirants who are not fitted you are at liberty to write me to that effect and to tell why in terms that will be plain; and if there are other aspirants who are fitted you are at liberty to tell me this and to give the 
Sinking into a fatalism that would come increasingly to dominate the last years of his life, Taft would observe that "even though among the appointees are a number who ought not to have been selected," the federal judiciary nevertheless "becomes better in its personnel the longer the Judges remain on the Bench, by reason of their judicial experience and education. They are independent, and having no ambition except to stand well with the Bar, they are by their experience and the teaching of the Bar rendered pretty good Judges before they get through." 447 "[T] $[$ he truth is that the Federal Judiciary is maintained by the system rather than by the excellence of the appointments. Take a man of average intelligence and education, make him independent, and give him a place where there is real competition among his fellow Judges, and the experience that he must have and the work that he can not avoid doing, and you not infrequently get a good Judge." ${ }^{448}$

Even though Taft aspired throughout his tenure to shift the appointment process away from political authority and toward those who possessed professional expertise, in the second half of the decade,

reasons - character, experience, age, etc. My acquaintance with you
justified me in believing that you would act solely in the interest of good
service. . . A real embarrassment in the matter of judicial appointments is
that the bar frequently lets the matter go by default, takes no concerted
action or makes scattering recommendations which conduct to no desirable
result.

Letter from WVD to George B. Rose (Sept. 23, 1927) (Van Devanter papers). Taft eventually supported Van Devanter in seconding Rose's recommendations, which were later undercut when Rose himself was forced to walk them back as "a bit too strong and enthusiastic to consist with the facts." Letter from WHT to John G. Sargent, Attorney Gen., U.S. (Oct. 31, 1927) (Taft papers). See Letter from WHT to John G. Sargent (Nov. 19, 1927) (Taft papers) ("I don't think that those gentlemen with whom I came to see you at the Department of Justice were entirely frank in their statement to Van Devanter and me or to you."). Taft subsequently performed his own investigation into the Arkansas judgeship and unearthed what he regarded as an excellent candidate, a former Governor of the State named John Ellis Martineau, who was a Democrat and who in the end was appointed. This was the same Judge Martineau whom Fiorello La Guardia would later accuse of racism in a Brooklyn courtroom in New York, where Martineau had been transferred pursuant to the Act of September 14, 1922. See supra note 144; Letter from Fiorello H. La Guardia to WHT (July 27, 1929); Letter from WHT to WVD (Aug. 1, 1929) (Taft papers); Letter from WHT to Fiorello H. La Guardia (Aug. 2, 1929) (Taft papers).

447. Letter from WHT to M.S. Sherman (Oct. 29, 1927) (Taft papers) ("But we ought not to have to depend on those factors to get good men. We ought not to have to educate our Judges at the expense of the public."); Letter from WHT to Arthur C. Denison, Judge, U.S. Sixth Cir. (Mar. 8, 1928) (Taft papers) ("It seems to be our fate to have to train Judges and not to get Judges who are fitted at the time.").

448. Letter from WHT to George D. Seymour (Nov. 25, 1928) (Taft papers). 
and especially after his heart attack of 1926, his efforts were derailed by the senatorial politics of the 69th Congress, as well as by his own flagging energy. Given his work on the Court and the Judicial Conference, he no longer possessed the boundless determination of earlier years to aspire to control nominations to the lower federal courts. Instead, in the second half of the decade, he chose to concentrate his remarkable energy on a massive new project: creating a home for the Supreme Court.

\section{A NEW SUPREME COURT BUILDING}

During Taft's Chief Justiceship, the Court was housed in what had been the old Senate Chamber. It had moved there in 1860 when the Senate decamped for larger quarters. The Old Chamber was an intimate, elegant room, furnished with "columns of native Potomac marble, gray painted walls, and mahogany furnishings." 449 It was a room that echoed with the historical grandeur of Webster and Clay and Sumner. It held great sentimental value for members of the Supreme Court Bar. ${ }^{450}$ Elihu Root, for example, who was no maudlin lawyer, told Taft that

I have always had a strong feeling, largely sentimental doubtless, in favor of the Court staying where it is. The associations of the chamber in which the court now sits are more interesting and impressive to me than those of any other place that I know; and I have no doubt that they tend to restrain the dangerous radicalism of you and Sutherland. ${ }^{451}$

But the space occupied by the Court was entirely impractical from an administrative point of view. ${ }^{452}$ It did not contain enough room

449. Residences of the Court: Past and Present: Part II: The Capitol Years, 3(1) SuP. CT. Hist. Soc'y Q. 2, 4 (1981).

450. Upon laying the cornerstone for the modern Supreme Court building, Chief Justice Charles Evans Hughes was moved to remark that "[i]t is no disparagement of this new enterprise to say that we shall leave that historic room with keen regret. In its dignity, in its simplicity, in its priceless memories as the former Senate chambers and for upwards of seventy years the seat of the Court, that room has no rival. It will be long, indeed, before this beautiful building can boast of the spiritual endowment which has blessed the old home." Charles Evans Hughes, Address of Chief Justice Hughes at Laying of Corner Stone, 18 A.B.A. J. 728, 728 (1932).

451. Letter from Elihu Root to WHT (Nov. 20, 1925) (Taft papers).

452. Good descriptions of the Court's difficulties in the old Senate Chamber may be found in the testimony of Taft and Van Devanter during a May 1928 congressional hearing. See Hearings on H.R. 13665, S. 4035, H.R. 5952, S.J. Res. 50, and H.R. 12290 Before the House Committee on Public Buildings and Grounds, 70th Cong. 3-4, 12-15, 18 (May 16, 1928) [hereinafter Hearings on H.R. 13665, S. 4035, H.R. 5952, S.J. Res. 50, and H.R. 12290]. 
for the clerk's office, the marshal's office, or the library. The Justices lacked office space. The Court's records were "scattered throughout the Capitol, the Senate Office Building, and the Library of Congress." ${ }^{453}$ There were no facilities for the bar or for the Solicitor General. There were no conference rooms in which Justices could receive and confer with guests. ${ }^{454}$ The Senate was continually appropriating more space from the Court. Taft remarked that the Senate was

of the porcine variety, ... spreading not only through the building where the Senate Chamber is, but clear to the middle of the Capitol, taking up all the old Congressional Library rooms, and giving us no place for the Bar, making it impossible for us to keep our records in any such shape that we can use them easily, and sending out of the Capitol all but three of the Justices. ${ }^{455}$

Taft was forced to engage in a constant and unseemly battle for space with Senators. ${ }^{456}$

The inadequacy of the Court's quarters had long been recognized. Beginning in 1888, Senator Justin Smith Morrill of Vermont sought repeatedly to pass legislation to provide a new building for the Court. ${ }^{457}$ "It is clear that the rooms now occupied in the Capitol by the Supreme Court are deplorably inadequate both in size and number for its proper accommodation - being inferior to what our people often offer to their county courts," Morrill argued, "and it

453. HANKIN \& HANKIN, supra note 2, at 5.

454. In the words of Chief Justice Hughes, "[t]he facilities of the essential offices of Clerk and Marshal have become shockingly insufficient. There is lacking decent provision for the vast accumulation of records. The constantly increasing volumes of the working library for bench and Bar require suitable housing. Counsel in attendance at the Court have been without the simplest conveniences for consultation and preparation for augment. ... Everything considered, I doubt if any high court has performed its tasks with so slender a physical equipment." Hughes, supra note 450 , at 728 .

455. Letter from WHT to Elihu Root (Nov. 22, 1925) (Taft papers). Root, a former Senator, answered Taft:

Your comments on the Senate's hogging all the space in the Capitol

building seem to be justified. They remind me of the sailor's verse about

the ship's cook:

He's greasy and he's lazy and he's frowsy and he's fat,

His face is large and dirty and his feet are large and flat,

And he knows no more of cooking than the steward's ginger cat. Letter from Elihu Root to WHT (Nov. 30, 1925) (Taft papers).

456. See, e.g., Letter from WHT to Charles Curtis (Feb. 26, 1923) (Taft papers).

457. See, e.g., S. 2492, 54th Cong. (1896); S. 828, 52nd Cong. (1892); S. 697, 51st Cong. (1889); S. 2727, 50th Cong. 5 (1888); S. 1196, 53rd Cong. (1893). 
is also equally clear that the space so occupied has long been needed and greatly coveted by Congress for its increasing necessities, for its offices and committees." 458 Even President McKinley in his State of the Union Address of 1898 commented on the "inadequate accommodations provided for the Supreme Court in the Capitol" and suggested "the wisdom of making provision for the erection of a separate building for the court and its officers and library upon available ground near the Capitol." 459

Chief Justices Fuller and White, however, opposed the idea of leaving the old Senate Chambers. ${ }^{460}$ But Taft was made of different stuff. Court management mattered to Taft in ways that it had not mattered to his predecessors. Notwithstanding the nostalgic beauty of the old Senate Chamber, Taft was determined to provide for the administrative necessities of the Court. If his predecessors had sought to steer clear of the legislative engagements necessarily entailed by the search for suitable new quarters, ${ }^{461}$ Taft actually enjoyed the give-andtake of the political arena.

The Judiciary Act of February 13, 1925, moreover, fundamentally altered the character of the Supreme Court itself, transforming it from a simple appellate court of last resort into the supervisor of the entire system of federal law. Transfigured into the head of a third branch of government, the Court required a new physical infrastructure adequate to that enlarged role. Taft believed that "as the chief body at the head of the judiciary branch of the Government," the Court deserved "to have a building by ourselves and one under our control." ${ }^{662}$ Even if many of his colleagues "would not really enjoy the amplitude and comfort" of a new building, the stakes

458. 21 CONG. REC. 3538 (1890).

459. 32 CONG. REC. 12 (1898).

460. Taft testified to Congress, "The truth is it was the attitude of the two Chief Justices that preceded me that delayed the effort ...."Hearings on H.R. 13665, S. 4035, H.R. 5952, S.J. Res. 50, and H.R. 12290, supra note 452, at 18-19. See 54 CONG. REC. 1715-16 (1917) (remarks of James R. Mann) (noting that the Court did not want to leave the Capitol despite its "very scant and insufficient" quarters).

461. Expressing the traditional view of a rigorously apolitical Court, James R. Mann proclaimed on the floor of the House in 1917, "The members of the Supreme Court of the United States can not go lobbying. They can not permit one of their employees to go lobbying. It is beneath their dignity, properly so, to even make a representation in reference to the matter" of a new building. 54 CONG. REC. 1716 (Jan. 19, 1917). Nothing could be further from Taft's sensibility.

462. Letter from WHT to Charles Curtis, Senate Majority Leader, U.S. Senate (Sept. 4, 1925) (Taft papers). 
for the future were high. ${ }^{463}$ "[T] $]$ hose of us who have responsibility ought to look after the welfare of those who come after us." 464

At first, however, Taft was preoccupied with other matters. Ever since the report of the McMillan Commission in 1902, ${ }^{465}$ which established the plan for the development of Washington's major buildings and parks for the first third of the twentieth century, ${ }^{466}$ it had been assumed that a new Supreme Court building would be constructed "on the square directly north of the Library" of Congress, east of the Capitol, where the Supreme Court is now located. ${ }^{467}$ Soon after he became Chief Justice, Taft was contacted by the Commission of Fine Arts, which Taft had established in 1910 to carry on the work of the McMillan Commission. ${ }^{468}$

The Commission had been asked to advise on a building project on the lot north of the Library of Congress, and it wanted to know if Taft might still desire that piece of property. ${ }^{469}$ Two months later, the Chairman of the Commission asked if Taft might be interested instead in a court building located on the south axis of the White House in the Tidal Basin, where the Jefferson Memorial is now located, so as to symbolize more concretely the symmetry and balance between the three branches of government. ${ }^{470}$ Taft dismissed the idea. "My

463. Id.

464. Id.; see also Hearings on H.R. 13665, S. 4035, H.R. 5952, S.J. Res. 50, and H.R. 12290, supra note 452, at 2 ("[I]f we perform any duty to those who come after us we ought to make as much effort as we can to have a separate building.").

465. See William Howard Taft, Washington: Its Beginning, Its Growth, and Its Future, 27(3) NAT'L GEOGRAPHIC MAG. 221, 277-79 (1915) (discussing the McMillan Commission).

466. The members of the Commission were outstanding. They included Daniel H. Burnham, Frederick Law Olmsted, Jr., Augustus Saint Gaudens, and Charles F. McKim. See id.

467. S. REP. No. 57-166, The Improvement of the Park System of the District of Columbia, at 38 (1902).

468. See Pub. L. No. 61-181, 36 Stat. 371, 371 (1910). Taft appointed to the Commission Daniel H. Burnham, Frederick Law Olmsted, Jr., Cass Gilbert, Charles Moore (who had been the private secretary to Senator McMillan), Thomas Hastings, Daniel Chester French, and Francis D. Millet. See H. Paul CaEmmerer, The COMMISSION OF FINE ARTS 1910-1963, at 3 (1964).

469. See Letter from Colonel Clarence Sherrill, Dir., Office of Pub. Bldgs. \& Grounds, to WHT (Dec. 16, 1921) (Taft papers) ("Unofficially the Commission of Fine Arts are advised that you look with favor upon the idea of erecting a building for the Supreme Court of the United States and are well disposed to a location balancing the Congressional Library.").

470. See Letter from Charles Moore, Chairman, U.S. Comm'n of Fine Arts, to WHT (Feb. 2, 1922) (Taft papers). Taft had appointed Moore to the Commission. See supra note 468. Taft would later seek to intervene with President Harding to save 
impression is that the Court would prefer to be nearer the Capitol." 471 And in any event, as Taft wrote to another correspondent, "I haven't heard that there is to be a new building for the Supreme Court in Washington. Some of my brethren are opposed to it - I would like itbut Congress is in no mood to put up new buildings." ${ }^{472}$

There matters lay, as Taft grew increasingly frustrated by the lack of space for the necessary administrative infrastructure of the Court. ${ }^{473}$ What suddenly spurred him into an intense campaign that would last to the end of his life was Stone's accession to the Court. In May 1925, Stone wrote Taft to complain about the "difficulties" he

Moore's job. See Letter from Cass Gilbert to WHT (Jan. 29, 1922) (Taft papers); Letter from WHT to Cass Gilbert (Jan. 31, 1922) (Taft papers); Letter from WHT to Francis E. Warren (Feb. 11, 1922) (Taft papers); Letter from Francis E. Warren to WHT (Feb. 14, 1922) (Taft papers); Letter from WHT to Cass Gilbert (Feb. 15, 1922) (Taft papers); Letter from Charles Moore to WHT (Mar. 10, 1922) (Taft papers); Letter from WHT to Warren G. Harding, President, U.S. (Sept. 5, 1922) (Taft papers); Letter from WHT to Charles Moore (Sept. 5, 1922) (Taft papers); Letter from WHT to Charles Moore (Nov. 5, 1922) (Taft papers). During the subsequent struggle to create a separate Supreme Court building, Moore would prove a most valuable ally.

471. Letter from WHT to Charles Moore, Chairman, U.S. Comm'n of Fine Arts (Feb. 3, 1922) (Taft papers) ("I appreciate the suggestion of the triangular relation between the three departments of the Government."). To Taft's annoyance, the idea was later revived by the New York Chapter of the American Institute of Architects. See Letter from Elihu Root to WHT (Nov. 20, 1926) (Taft papers); Letter from WHT to Charles P. Taft II (Nov. 22, 1925) (Taft papers) ("I think of all the places in the World we would not wish to go, that is it."); Letter from WHT to Elihu Root (Nov. $22,1925)$ (Taft papers) ("I have always thought that the square corresponding to the Congressional library was the place where our Court Building ought to be in a dignified park-like space, and a building that we can control. I am quite sure that no member of the Court would wish to go down to the place these architects insist upon. I believe in system landscaping, but I think you can carry the analogy between the branches of the Government and the geography of Washington too far. Analogies are all right, but they are mostly used in the pulpit where they are usually wrong."). Herbert Hoover also later revived this idea. See Letter from Herbert Hoover to HFS (Jan. 13, 1927) (Stone papers); Letter from Cass Gilbert to WHT (Nov. 7, 1928) (Taft papers); Letter from WHT to Cass Gilbert (Nov. 9, 1928) (Taft papers). Frederic A. Delano, Chair of the National Capital Park and Planning Commission, also revived the idea. See Letter from WHT to Cass Gilbert (Jan. 23, 1928) (Gilbert papers at the Supreme Court of the United States) See infra at 544.

472. Letter from WHT to Jules Guerin (Dec. 2, 1922) (Taft papers).

473. See supra note 219 and accompanying text. Taft was forced to decline an offer to donate Chief Justice Jay's robes to the Court: "The truth is that the quarters of the Court are very contracted. We have luncheon in the Robing Room and haven't room enough even for a sofa upon which to lie down. A few of the Justices are given rooms in the Capitol, but far removed from the Court. The Conference Room is so crowded with our law books that there is no room there." Letter from WHT to Mrs. Peter Jay (Aug. 5, 1924) (Taft papers). 
was suffering "for want of adequate office facilities." Stone had hoped to find "a suitable house in Washington with sufficient space for a library and an office for my law clerk and clerical assistant, but I have not succeeded in doing that, and may not succeed in doing it until I have built a house." Senator Henry Keyes of New Hampshire had kindly loaned Stone "the office of the Committee on Contingent Expense," but the room would have to be returned when Senate reconvened in the fall.

What I need, and need very badly, is a room lighted by daylight, with sufficient wall space to hold a complete set of Federal reports and reference books most commonly used, and a room nearby for the use of my clerical assistants.

There are a number of rooms in the dome of the Capitol which are ideal for this purpose and which I understand were originally assigned to Justices of the Court. These rooms, however, have been gradually taken over by Senators so that the only ones now in use by the Court are those rooms occupied by Mr. Justice Sanford and Mr. Justice Sutherland. I very much hope that some way may be found whereby two or these rooms may be set apart for my use. Rooms at a distance, or in another building, would not be of great service, as I find that I am under necessity of sending to the Supreme Court Law Library for additional volumes. ${ }^{474}$

Taft promised to go begging to the Senate. ${ }^{475}$ Two days later, Stone wrote to complain again that books in the Supreme Court library had been checked out by legislators and given to friends and remained missing "for weeks and perhaps months at a time." ${ }^{476}$ Stone asked that there be a rule prohibiting persons other than Justices from

474. Letter from HFS to WHT (May 25, 1925) (Stone papers).

475. See Letter from WHT to HFS (May 26, 1925) (Taft papers). As fall approached, Stone grew increasingly frantic about the need for office space, fearing that if he didn't find a house "I shall be about like a stray dog." Letter from HFS to WHT (Aug. 30, 1925) (Taft papers). See Letter from HFS to WHT (Oct. 21, 1925) (Taft papers) ("I have ... received a request from Senator Keyes' clerk requesting me to vacate the room I am now occupying, with the intimation that the sooner I leave the better. Do you think it is too much to ask that the rooms originally assigned to Supreme Court Justices be restored to the Court, and if they are occupied by others, it is only at the sufferance of the Justices entitled to occupy them."). Taft lobbied hard but unsuccessfully for Stone. See Letter from WHT to Charles Curtis (Sept. 4, 1925) (Taft papers); Letter from WHT to HFS (Oct. 22, 1925) (Taft papers). Eventually, Senator George Moses of New Hampshire found a room for Stone in the Senate Office Building. Letter from HFS to George H. Moses (Nov. 17, 1925) (Taft papers). The room was distant from the Supreme Court library and "below street level [and so] not as well lighted as I would like." Letter from HFS to Charles Curtis (Nov. 17, 1925) (Taft papers).

476. Letter from HFS to WHT (May 27, 1925) (Taft papers). 
withdrawing books (in the absence of duplicates). ${ }^{477}$ Taft concurred, ${ }^{478}$ but then realized that Stone was raising questions that required structural solutions:

The truth is that if we could have a separate building for the Court and for the Law Library, we could probably get money enough to make our Library very much more comprehensive and useful than it now is. I mean at the next Conference to bring up the question whether we can get a majority of our Court to favor the construction of a new building. I am very much in favor of it, and I would like to have the authority of the Court to invite the Congress to frame legislation on the subject to our needs. ${ }^{479}$

Taft later testified that "[w]e took a vote, and it was 5 to 4 " to seek to leave the Capitol and to construct a new Supreme Court building. ${ }^{480}$ Taft knew that Senator Reed Smoot of Utah was then authoring a bill to authorize about $\$ 50,000,000$ for the construction of new public buildings in Washington, and he wanted the Supreme Court to be included in that authorization. ${ }^{481}$ He wrote Smoot in July 1925 "with the authority of the Court" to ask for a separate building for the sole use of the Court "as the head of the Federal Judiciary, and, in a constitutional sense, the head of the Judiciary of the Nation." ${ }^{\prime 42}$

477. See id.

478. Letter from WHT to Herbert Putnam, Eighth Librarian of Congress, Library of Congress (May 28, 1925) (Taft papers).

479. Letter from WHT to HFS (May 28, 1925) (Taft papers). A number of factors probably influenced Taft's judgment to seek a Conference vote at that time. Stone likely constituted a fifth vote in favor of the Court leaving the Capitol. See infra note 480 and accompanying text. Taft was also aware of the large capital building projects then underway in Congress. See infra note 481 and accompanying text.

480. Hearings on H.R. 13665, S. 4035, H.R. 5952, S.J. Res. 50, and H.R. 12290 , supra note 452 , at 19 . The only remaining record of a vote, however, dates to a year later in 1926. See Letter from WHT, WVD, PB, HFS, and Edward T. Sanford to Reed Smoot (June 8, 1926) (Stone papers) ("We, constituting a majority of the members of the Supreme Court, respectively request that you bring before the Building Commission the matter of securing a site for a new Supreme Court Building, in accordance with the provision of the Building Act. We, the undersigned, believe that the best place for a Supreme Court building is the square or block immediately north of the present Congressional Library, and across from and opposite the Capitol grounds."). The four Justices opposing the move were apparently Holmes, McReynolds, Brandeis, and Sutherland.

481. Emmet Dougherty, $\$ 50,000,000$ To Add Beauty and Dignity to Capital's Skyline: Stately Edifices of Classic Design to Accommodate an Army of Clerks, N.Y. HERALD TRIB., Aug. 15, $1926 \S 3$, at 3.

482. Letter from WHT to Reed Smoot (July 3, 1925) (Taft papers). Taft laid out the case for a new building:

Plans have been adopted in the past and bills have been introduced for the erection of such a building, but the conservatism of some of the members, especially the Chief Justices, has interfered with the successful 
Smoot was unimpressed. He had "carefully refrained from making any statement whatever as to what buildings this money will be expended for," and he did not wish to designate particular buildings in advance of the entire authorization for fear of getting "into a fight on the floor." 483

It may seem odd to authorize $\$ 50,000,000$ for federal buildings without having a clear idea of the purpose of the funding, particularly in the tight-fisted budgetary atmosphere of the Coolidge Administration. ${ }^{484}$ It is true that the federal workforce had doubled in the preceding twenty years, ${ }^{485}$ and it is also true that there was a desperate need for proper accommodations. ${ }^{486}$ But Smoot's bill

passing of the bill. We have now come, however, to a situation where a majority of the Court is strongly in favor of the construction of a separate building for the Court. Most of the Judges are obliged to have their offices and official studies in their own houses or apartments. As Chief Justice, I have no office at the Capitol and must use the Conference Room and Library of the Court to meet any persons who come to see me at the Capitol, either officially or otherwise. Justice Stone is most embarrassed now by the inability to secure a decent room for himself at the Capitol where he can have his Law Clerk and Secretary do his work. I have pleaded with the Committee of the Senate having control of this matter, and have not been able to secure a proper room for him. The records of the Clerk's office are piling up in such a way as to prevent their being housed in an accessible place. The members of the Bar of the Supreme Court have no place to meet or confer except in the crowded offices of the Clerk. The Marshal's office is greatly congested with his employees. The Library for the Court is so crowded that the shelves have to be carried to the ceiling and the books reached upon step-ladders.

Id.

483. Letter from Reed Smoot to WHT (July 6, 1925) (Taft papers).

484. Dougherty, supra note 481, § 3, at 3 .

485. See Hoover Acclaims Beautified Capital, N.Y. Times, Apr. 26, 1929, at 14 ("President Hoover said that there was need for additional building to house the 70,000 Federal employees, whose number was now twice that of a score of years ago.").

486. In his Memoirs, Herbert Hoover described how when he became Secretary of Commerce the Department consisted of "congeries of independent bureaus" that "were housed in fifteen different buildings, mostly rented, and some of them condemned by the District of Columbia fire and health departments." HERBERT Hoover, The Memoirs of Herbert Hoover: The Cabinet and the Presidency 1920-1933 42 (1952). Hoover recalled that "[i]n 1924, when the new building program for the Departments was authorized by Congress, I secured that the first of these building should be for the Commerce Department. The building was not completed during my term as Secretary, so that for eight years I occupied a corner room of a rented apartment building on Nineteenth Street, especially superheated for summer." Id. at 44. 
contributed to a spate of federal construction in the $1920 \mathrm{~s}^{487}$ that did not reflect merely a utilitarian desire to avoid the cost of rental space for inflated bureaucracies or to improve manifestly inadequate facilities. It also expressed the growing conviction that Washington D.C. should be rebuilt "to make the national capital as splendid as our new status in the world." 488 It signified "the dawning consciousness that this capital is an equivalent of the Rome of Augustus." 489

487. See generally Dougherty, supra note 481 (reporting on Senator Smoot's proposed bill); Charles H. Whitaker, Building for the Glory of Washington, N.Y. Times, Mar. 6, 1927, at 6.

488. Anne O'Hare McCormick, Building the Greater Capital: A New Washington Rises as the Symbol of America's New Status, N. Y. TimEs, May 26, 1929, at 1 ("The real pressure behind the new Washington is the new America. We have heard a good deal during the past few years of the United States as a great world power, perhaps the greatest. But that conception of our place in the international scheme is new to Americans, and in the country at large has been discounted as political hyperbole. Very slowly the legend has acquired the vitality of a fact, predicated not upon a vague political pre-eminence but upon the clear evidence of our mechanistic supremacy. We begin to see ourselves first among the nations by the tangible standards the populace recognizes-wages, motor power, plumbing. Gradually our primacy has impressed ourselves. The capital, says Mr. Hoover, is 'the symbol of the nation."').

In 1929, the American Institute of Architects issued a report approving the plan to beautify Washington, proclaiming that " $[\mathrm{t}]$ he country at large has caught the idea of a great capital truly representative of the genius and power of the nation." Would Speed Plan to Beautify Capital, N.Y. TIMES, Apr. 24, 1929, at 30. President Hoover approved the Institute's report, declaring in a speech "that in design and utility the new structures should be the symbol of America and the lasting inspiration of the present and future generations." Hoover Acclaims Beautified Capital, supra note 485, at 14 .

Contrasting American pre-eminance with Roman dominion, which was based upon "military force," Reinhold Neibuhr proclaimed in the popular press: "We are the first empire of the world to establish our sway without legions. Our legions are dollars. Our empire was developed almost overnight. At the beginning of the World War we were still in debt to the world. ... [But] our economic relationship to the world was completely altered by the war. We wiped out our debt and put the world in our debt by well-nigh thirty billion dollars in little more than a decade." Reinhold Neibuhr, Awkward Imperialists, ATL. MonThly, May 1930, at 670. During the 1920s, the United States became "the world's biggest lender, and its economy was the largest in the world: by 1929, it produced 42 percent of the world's output (Great Britain, France, and Germany together produced 28 percent)." JILL LEPORE, THESE TRUTHS: A HISTORY OF THE UNITED STATES 406 (2018).

489. McCormick, supra note 488, at 1 . The focus on Roman architectural themes dated back at least to the McMillan Commission. See Sonja Duempelmann, Creating Order with Nature: Transatlantic Transfer of Ideas in Park System Planning in Twentieth-Century Washington D.C., Chicago, Berlin and Rome, 24 Plan. PERSP. 143, 150-51 (2009). 
Writing at the end of the decade, one commentator noted that "[t]he proudest boast of the Emperor Augustus was that he found Rome a city of brick and left it a city of marble. All Washingtonians seem bent upon following in his footsteps and making our national capital, if not a marble city, at least a white city." ${ }^{490}$ Taft was fortunate that he could push a project for an impressive marble Supreme Court building - and in the end it would be the most magnificent of all the buildings to emerge from the decade - at exactly the moment when America was becoming infatuated with its own grandeur. ${ }^{491}$

This is not to say that the campaign for the Supreme Court building was easy. In fact it was extraordinarily difficult and would consume Taft for the remainder of the decade. It would require all of Taft's immense tact and influence.

Taft sought to circumvent Smoot's repudiation by inducing New Hampshire Senator George Moses to offer an amendment on the floor of the Senate specifically authorizing a Supreme Court building, ${ }^{492}$ but the amendment was voted down. ${ }^{493}$ Undeterred, Taft realized that the Senate and House versions of the bill differed, and so, lobbying hard and effectively with the House conferees and with Moses, Taft engineered a miraculous transformation. ${ }^{494}$ The bill emerged from

490. Fitzhugh L. Minnigerode, Washington Doffs Its Brick for Marble: White Masterpieces of Architecture Replace Old Red Buildings as Townsmen Join the Government in Beautification Plan, N.Y. TIMES MAG., Sept. 21, 1930, at 18 ("The most notable buildings either recently erected or soon to be erected include the Departments of Commerce, Justice, Posts and Labor. Then we shall see arise in majesty a new building for the Supreme Court, another for the Interstate Commerce Commission, the Archives Building, Independent Offices Building, House of Representatives Annex and a number of lesser ones ....").

491. See generally Andrew W. Mellon, The Development of Washington, AM. MAG. ART, Jan. 1929, at 1 (discussing the general plan to beautify Washington). The normally penny-pinching Mellon stressed the importance of providing "a magnificent setting for the requirements of modern civilization" and that the city of Washington be clothed in "that beauty and dignity to which it is entitled." Id. at 9.

492. Letter from WHT to Robert A. Taft (Apr. 18, 1926) (Taft papers).

493. 67 ConG. ReC. 8667-73 (May 4, 1926). On the floor, Smoot argued that the Department of Justice needed a new building far more than the Supreme Court: "We have those employees in temporary buildings ... that are liable to fall down at any time. The Supreme Court is not suffering, nor are Senators suffering, as those people are." Id. at 8668. Smoot dismissed Moses's point that most of the Justices were forced to work at home, observing that "the Senator knows that they would have offices at home, whether they had two or three rooms down here or not," because they "take their work home at night, and would do it no matter what might happen in the way of getting larger quarters." Id. at 8668-69.

494. Catherine Hetos Skefos, Strictly Construction: The Supreme Court Gets a Home, Y.B. Sup. CT. HIST. Soc'Y 25, 30 (1976). See Letter from WHT to HFS (May 
conference specifically providing for a new building for the Supreme Court. 495

The next step was for the Building Commission, in consultation with the Commission of Fine Arts, to designate a site for the building and to condemn and acquire the property. This phase of the project also proved problematic. The Building Commission was chaired by the hostile Smoot. ${ }^{496}$ Taft, even though laid up in the hospital with

11, 1926) (Stone papers); Letter from WHT to George H. Moses, President pro tempore, U.S. Senate (May 11, 1926) (Taft papers); Letter from WHT to Richard N. Elliott, Congressman, U.S. House of Representatives (May 11, 1926) (Taft papers); Letter from WHT to Robert A. Taft (June 17, 1926) (Taft papers).

495. See Pub. L. No. 281, 44 Stat. 631 (1926); H.R. REP. No. 69-1223 on H.R. 6559 (1926) (Conf. Rep.). Brandeis was disappointed. "I hadn't heard that the U.S.S.C. building project has been killed," he wrote Frankfurter, but "I hope so." Letter from LDB to FF (May 23, 1926), in BRANDEIS FRANKFURTER CORRESPONDENCE, supra note 41, at 241. After the passage of the Act, however, there seems to have been general acquiesce on the part of all dissenting Justices. "They all agreed to it after the thing was decided. They are all in favor of it now," Taft later testified. Hearings on H.R. 13665, S. 4035, H.R. 5952, S.J. Res. 50, and H.R. 12290, supra note 452, at 19.

In the summer of 1926, Taft wrote his colleagues asking for suggestions about the new building. Brandeis replied by saying, "The matter of the Supreme Court building I leave wholly to you." Letter from LDB to WHT (July 20, 1926) (Taft papers). See Letter from WHT to OWH (July 21, 1926) (Holmes papers); Letter from George Sutherland to WHT (Aug. 9, 1926) (Taft papers); Letter from Edward T. Sanford to WHT (Taft papers). Sanford had just consulted with Milton Medary, Jr., the president of the American Institute of Architects, who recommended hiring a "great architect" who could then propose the "plan best adapted to house the physical necessities and express in suitable form the dignity and position of the head of a coordinate branch of the Government. He knows of no previous effort to do this- the courts of the various countries being generally housed as adjuncts of the legislative branches." Id.; see also Letter from WHT to Edward T. Sanford (Aug. 21, 1926) (Taft papers).

Stone apparently returned so many suggestions that Taft was forced to caution him: "I shall forward them to Moore, but of course this is most informal, and when the matter comes up seriously for consideration, we shall have to discuss it very fully in conference." Letter from WHT to HFS (July 27, 1926) (Stone papers). McReynolds made the constructive suggestion that "[s]ome valuable information might be obtained by inspecting the quarters provided for the courts of the larger States." Letter from JCM to WHT (July 27, 1926) (Taft papers). A week later Taft instructed his secretary "to write to all the chief Justices of the Supreme Courts of the various States ... requesting them to send him a description of their Supreme Court buildings, for use in constructing the new building for the Supreme Court." Letter from Wendell W. Mischler to William R. Stansbury (Aug. 7, 1926) (Taft papers).

496. Taft wrote his son that by altering the authorization bill, Taft had “interfered with Smoot's plans . . . and he is not disposed to help us. . . I have written to other members of the committee, and I think they are quite inclined to help, but Smoot is a dominating kid of fellow and he is hard to beat in that kind of thing and is 
heart fibrillation, ${ }^{497}$ quickly summoned his five-person Court majority to press for immediate action. "We are anxious that the place be designated, and that the proceedings be taken for the condemnation of the property at once, for the reason that if there is delay, the property will probably appreciate in value, and it would seem to be wise by your action to fix the date of the valuation as soon as possible... . May we ask, therefore, that at your next meeting of the Board this matter be brought up so that action may be taken?"498 Taft bombarded members of both Commissions with urgent appeals to action. ${ }^{49}$

a cheese-pairing, small-minded kind of fellow without any imagination. He would be glad to include us with the Department of Justice or some other court. He has no soul above small matters." WHT to Robert A. Taft (June 17, 1926) (Taft papers).

497. See supra notes 18-24 and accompanying text.

498. Letter from WHT, WVD, PB, HFS, Edward T. Sanford to Reed Smoot, (June 8, 1926) (Stone papers); see also supra note 480 and accompanying text; Letter from WHT to WVD (June 8, 1926) (Van Devanter papers) ("I am anxious that this matter be pressed, and therefore I want to take formal action by the majority of the Court, so that we may require the Commission to give attention.").

499. See, e.g., Letter from WHT to Claude A. Swanson, Senator, U.S. Senate (June 8, 1926) (Stone papers) ("The majority of the Court have applied to Senator Smoot, as Chairman of the Building Commission, asking your Commission to take steps to authorize the acquisition of the lot just north of the Congressional Library for a Supreme Court building, in accordance with the Act, and I write to ask you to promote the matter as far as you can as a member of the commission. ... After the proceedings are begun, of course nothing can be done in the way of building or adding to the damages to be imposed on the Government. Quick action, therefore, would be in the interest of economy."). Taft sent this same letter to commission members Rep. Fritz G. Lanham, Rep. Richard N. Elliott, David Lynn (Architect of the Capitol), James A. Vetmore (Supervising Architect of the Treasury), and Major U.S. Grant (Executive officer of the Commission). See Letter from WHT to Charles Moore, Chairman, Comm'n of Fine Arts (June 8, 1926) (Stone papers); Letter from Richard N. Elliot, Congressman, U.S. House of Representatives, to WHT (June 9, 1926) (Stone papers) ("I will be glad to do anything I can to assist you get the site for the Supreme Court as you requested."); Letter from Claude A. Swanson, Senator, U.S. Senate, to WHT (June 9, 1926) (Stone papers); Letter from Reed Smoot, Senator, U.S. Senate, to WHT (June 9, 1926) (Stone papers); Letter from Fritz G. Lanham, Congressman, U.S. House of Representatives, to WHT (June 10, 1926) (Stone papers); Letter from Charles Moore, Chairman, Comm'n of Fine Arts, to WHT (June 10, 1926) (Stone papers) (notifying Taft that "Smoot has called a meeting of the two Commissions on June 17th, and there is no question that the Commission of Fine Arts will stand by their recommendation" to purchase the lot north of the Library of Congress); Letter from David Lynn, Architect of the Capital, to WHT (June 10, 1926) (Stone papers) ("I will do everything in my power to bring about the acquisition of this lot as a site for the future home of the Supreme Court."); Letter from WHT to Richard N. Elliott, Congressman, U.S. House of Representatives (June 10, 1926) (Stone papers); Letter from WHT to Claude A. Swanson (June 10, 1926) (Stone papers); Letter from WHT to Reed Smoot (June 10, 1926) (Stone papers); Letter from WHT to Charles Moore (June 11, 1926) (Taft papers). Taft also lobbied with Treasury 
When the two Commissions met together on June 17, Taft was still incapacitated, and so he "got Van Devanter to go, together with Stone and Sanford, and Van Devanter presented the matter." ${ }^{500}$ Van Devanter recounted to Butler that

\begin{abstract}
[t]he thing passed off very pleasantly, save that Justice Stone made some suggestions respecting the architectural features and the size of the building which led to a little discussion and to inquiry whether the site was appropriate for a building of the size outlined by him. It seemed to me this was a mistake so I ventured to put an end to it by saying that we had every confidence that the committee would arrange for a building which in architectural features would be of such dignity as would be entirely fitting and would adjust the dimensions so that they would comport both with our needs and the particular site and surroundings; that these were matters of detail which undoubtedly could be worked out in an entirely satisfactory way by architects such as they would employ; and that a mere glance at the suggested site would demonstrate that its area and dimensions would meet every requirement for the next 500 years. This seemed acceptable to the committee and our Brother Stone acquiesced. The committee did not come to a decision about the site at that time but there is some reason for believing that they will choose the site selected. I endeavored to point out that there was great need for choosing a site in close proximity to the capitol building and to the Congressional Library; that the site suggested near the Tidal Basin was not at all appropriate; and that the building should be devoted entirely to the Court. ${ }^{501}$
\end{abstract}

The authorization bill attracted a great deal of attention in the press, which stressed the importance of the Court as "the balance wheel by which the affairs of the Nation and its relation to the States are kept in working order" and which therefore deserved to occupy "one of the most imposing buildings in the capital, noted as the most beautiful city of the world, and one whose buildings reflect the wealth and power and dignity of the American people and the greatest

Secretary Andrew Mellon. See Letter from WHT to Andrew Mellon (June 11, 1926) (Taft papers).

500. Letter from WHT to Robert A. Taft (June 17, 1926) (Taft papers).

501. Letter from WVD to PB (June 21, 1926) (Van Devanter papers). Although Taft regarded Van Devanter and Stone as "the committee of the Court to attend to this matter," the incident related by Van Devanter makes clear why both he and Taft came increasingly to distrust Stone's practical good sense. Letter from WHT to WVD (June 8, 1927) (Van Devanter papers). "The trouble with our dear friend Stone," Taft wrote Van Devanter, "is that he is too full of views and not too full of tact. I can hear him lecturing to Mellon on the mistakes of architecture in all the public buildings of Washington except the Capitol, the White House, the Lincoln Memorial, and the Washington Monument." Letter from WHT to WVD (June 29, 1927) (Van Devanter papers). 
Government that ever existed." ${ }_{502}$ But the Building Commission did not act, forcing Taft to engage in yet another lobbying campaign to "stir" Smoot up. ${ }^{503}$

The Commission finally concluded in November 1926 that the Court building ought to be situated where the McMillan Commission had long ago sited it, and Taft turned his attention to the next task, which was to secure an appropriation sufficient to acquire the designated lots north of the Library of Congress. The Assistant Secretary of the Treasury thought that $\$ 1,500,000$ would be sufficient, but Taft believed that $\$ 1,700,000$ was closer to the mark. ${ }^{504}$ There was also the question of whether the appropriation would go into the General Deficiency Bill or the Urgent Deficiency Bill. The latter would mean "an advance of two months for us, so that we can get in our litigation ahead of the great amount of litigation that is necessary in the condemnation of the triangle and other lots contemplated in the general improvement." ${ }^{505}$ Against the advice of the Director of the

502. Will P. Kennedy, New Home Needed by Supreme Court, WASH. EvENING Star, July 21, 1926, at 2. See Carson C. Hathaway, At Last A Home for the Supreme Court, N.Y. Times MAG., Sept. 26, 1926, at 13.

503. Letter from WHT to George H. Moses, Senator, U.S. Senate (Oct. 3, 1926) (Taft papers); WHT to Charles Moore, Chairman, Comm'n of Fine Arts (Nov. 8,1926 ) (Taft papers) ("I saw Senator Smoot yesterday, and I gathered the impression, from what he said, that the Building Commission was to meet this week and to put everything through.... While Smoot demurred to having a Supreme Court building at all, and suggested that it might be wise to wait until the Capitol was enlarged and to put the Supreme Court in there, I rather think that he yielded to the suggestion that was provided in the law and that we should have a lot, and that he will be in favor of that lot. He says it will have to be condemned, because the idea of the owners as to the value of the lot is rapidly expanding.").

504. Letter from WHT to Charles Moore, Chairman, Comm'n of Fine Arts (Nov. 24, 1926) (Taft papers). See Letter from WHT to WVD (Nov. 24, 1926) (Taft papers). Taft ultimately turned out to be correct.

505. Letter from WHT to Charles Moore, Chairman, Comm'n of Fine Arts (Jan. 1, 1927) (Taft papers). 
Bureau of the Budget and of Van Devanter, ${ }^{506}$ Taft went directly to the Secretary of the Treasury for assistance. ${ }^{507}$

Coolidge ultimately transmitted a request to include $\$ 1,700,000$ in the Urgent Deficiency Bill. ${ }^{508}$ Due to opposition in the House, and despite Taft's lobbying, the appropriation was cut down in conference to $\$ 1,500,000 .{ }^{509}$ Taft fretted as the Urgent Deficiency Bill was held up by a disagreement between the Senate and the House. ${ }^{510}$ But by the end of February 1927 the funds were appropriated, and Taft could report to his son that

[w] have got through our appropriation of $\$ 1,500,000$ to purchase our Supreme Court lot, so that I think it is fairly certain now that the lot will be purchased in due time by condemnation, and that we can begin with the next Congress to get our appropriations for the building. My prayer is that I may stay long enough on the Court to see that building constructed. If I do, then

506. Letter from H.M. Lord to WHT (Dec. 22, 1926) (Taft papers) (writing that the Assistant Secretary of the Treasury stated "that it would interfere, to some extent, with their consideration of this matter as a whole if a special estimate for the Supreme Court building site was submitted in advance with a view to its inclusion in the urgent deficiency bill"); Letter from WHT to WVD (Dec. 27, 1926) (Taft papers), in which Van Devanter wrote in a handwritten return: "I supposed they were intending to act as expeditiously as possible and am a little disappointed to find it is otherwise. But as there will be need for their cooperation later on I am disposed to believe it better to let the matter take the course they have selected").

507. See Letter from WHT to Charles Moore, Chairman, Comm'n of Fine Arts (Jan. 2, 1927) (Taft papers); WHT to Charles P. Taft II (Jan. 2, 1927) (Taft papers); WHT to Charles Moore (Dec. 28, 1927) (Taft papers).

508. 69 CONG. REC. 1862, 1908 (1927) (highlighting a communication from the President of the United States transmitting supplemental estimate of appropriation for the Treasury Department for the fiscal year ending June 30, 1927, for the acquisition of a site for a building for the Supreme Court of the United States for $\$ 1,700,000)$.

509. H.R. ReP. No. 69-1972, at 1862 (1927). See Letter from WHT to Claude A. Swanson, Senator, U.S. Senate (Jan. 25, 1927) (Taft papers); Letter from WHT to Charles P. Taft II (Jan. 30, 1927) (Taft papers).

510. See Letter from WHT to Charles P. Taft II (Feb. 20, 1927) (Taft papers) ("Congress is very exasperating. I am afraid I may lose my appropriation for the Supreme Court lot. I got it along famously and I thought I was going to get it through quickly. It was in the Urgent Deficiency Bill. But they have got into a row over that bill between the two Houses . . . and I don't know what is going to happen."); Letter from WHT to Robert A. Taft (Feb. 20, 1927) (Taft papers) ("I got it into the Urgent Deficiency Bill because I thought it would go through more quickly than if it waited for the General Deficiency Bill, and now it looks as if the General Deficiency Bill might go through and that the Urgent Deficiency Bill might fail. I am going to see what I can do about it."). 
I shall have the right to claim that it was my work, for without me it certainly would not have been taken up at this time. It is really very necessary..$^{511}$

The condemnation procedure, however, turned out to be "dreadfully slow and most exasperating." 512 Although Taft hoped it could be settled by summer $1927,{ }^{513}$ it was not ultimately concluded until March 1929.514 The land was valued at $\$ 1,768,000$, as Taft had predicted, ${ }^{515}$ which required the passage of yet another deficiency bill. ${ }^{516}$ Delay was also caused by the "fool law" of the District of Columbia "that requires the making of abstracts . . . to be let to the lowest bidder. The company awarded the bid has no adequate organization to do the work." 517 To Taft's intense annoyance, this prevented the valuation proceedings from prompt initiation. Solicitor General William D. Mitchell, a former law partner of Butler and close

511. Letter from WHT to Charles P. Taft II (Feb. 27, 1927) (Taft papers). Ironically, Congress had "got a filibuster which seems likely to beat the last deficiency bill in which a great many things necessary are provided for . . . By great good luck, I got my appropriation for the Supreme Court lot through in the first and urgent deficiency bill. I thought I was going to lose that, but it has gone through and we are now engaged in seeking to negotiate the purchase of the property preliminary to condemnation proceedings." Letter from WHT to George D. Seymour (Mar. 3, 1927) (Taft papers).

512. Letter from WHT to Robert A. Taft (Nov. 17, 1928) (Taft papers). See Letter from WHT to Henry H. Glassie (July 19, 1928) (Taft papers).

513. See Letter from WHT to William D. Mitchell, Solicitor Gen., U.S. (May 25, 1927) (Taft papers).

514. The Deficiency Bill that was necessary to pay for the costs of condemnation over and above the $\$ 1.5$ million already appropriated ended up mired in controversy and was not passed until March 4, 1929. Pub. L. No. 70-1034, 45 Stat. 1614 (1929). See Letter from WHT to Robert A. Taft (Feb. 3, 1929) (Taft papers); Letter from WHT to William R. Wood, Congressman, U.S House of Representatives (Feb. 4, 1929) (Taft papers); Letter from Mrs. Burnita Shelton Matthews to WHT (Feb. 6, 1929) (Taft papers); Letter from WHT to Mrs. Burnita Shelton Matthews (Feb. 7, 1929) (Taft papers). After the deficiency bill passed, moreover, the Treasury department still delayed full payment until all claims on the condemned property were conclusively settled. See Letter from Mrs. Burnita Shelton Matthews to WHT (Mar. 7, 1929) (Taft papers); Letter from WHT to Mrs. Burnita Shelton Matthews (Mar. 9, 1929) (Taft papers).

515. See Letter from WHT to Chairman, Comm'n of Fine Arts (Nov. 24, 1926) (Taft papers); Letter from WHT to Henry H. Glassie (Nov. 22, 1928) (Taft papers); Letter from WHT to Charles P. Taft II (Nov. 26, 1928) (Taft papers) ("The result vindicates our judgment, and is a reason too for our feeling that the result is about right.").

516. See Letter from WHT to Robert A. Taft (Dec. 2, 1928) (Taft papers); Letter from WHT to Cass Gilbert (Dec. 7, 1928) (Taft papers). The passage of that deficiency bill was in turn delayed. See supra note 514 and accompanying text.

517. Letter from WHT to HFS (June 28, 1927) (Stone papers). 
friend of both Van Devanter and Taft, took it upon himself to speed along the process as best he could. ${ }^{518}$

Delay was also caused by the fact that designated lots were partially occupied by the National Woman's Party (NWP), which in 1921 had purchased a building on the lots known as the "Old Brick Capitol" that been used in 1814 after the original Capitol had been burned by the British. Justice Stephen Field had lived in the building for some time, and James Monroe had been inaugurated President there. ${ }^{519}$ The NWP had acquired the site to "serve as a watch tower guarding women's interests in all national legislation and keeping the women of all States in touch with what Congress is doing." 520

The NWP insisted on what Taft (and the jury that ultimately decided the property's valuation) considered an extortionate price for their land, due to its "valuable historical interest." 521 The NWP in fact created something of a small political furor. 522 "Everything," Taft

518. See Letter from William D. Mitchell, Solicitor Gen., U.S., to WHT (May 24, 1927) (Taft papers); Letter from WVD to WHT (June 15, 1927) (Van Devanter papers); Letter from WHT to WVD (June 22, 1927) (Van Devanter papers); Letter from WVD to WHT (June 25, 1927) (Van Devanter papers); Letter from WHT to HFS (June 28, 1927) (Stone papers); Letter from WHT to William D. Mitchell (Aug. $12,1927)$ (Taft papers).

519. Women to Keep a 'Watch Tower' Facing Capitol, N.Y. Times, May 9, 1921 , at 1.

520. Women Will Ask Equality in Law, N.Y. TIMES, Mar. 21, 1921, at 14 (quoting Elsie Hill, temporary Chair of the Party); see also Peter Geidel, National Woman's Party and the Origins of the Equal Rights Amendment, 1920-23, 42 Historian 557, 557 (1980). See generally Christine A. LunARDini, From EQUAL Suffrage to Equal Rights: Alice Paul and the National Woman's Party, 1910-1928 (1986) (discussing the history of the Party).

521. Letter from WHT to Robert A. Taft (Nov. 17, 1928) (Taft papers) ("It is just a broken down old building that ought to be removed, but they are a lot of women who are most unprincipled and attempting to use every method possible to squeeze up the amount they are to derive from the Government."). Charles Moore, Chairman of the Commission of Fine Arts, considered the historical claims entirely frivolous in light of the drastic architectural changes the building had undergone. See Letter from Charles Moore to WHT (Nov. 22, 1926) (Taft papers); Letter from WHT to Charles Moore (Nov. 24, 1926) (Taft papers). The NWP had purchased the building in 1921 for $\$ 134,000$ and was seeking to receive $\$ 1,000,000$ for it during the condemnation proceedings seven years later. 69 CONG. REC. 10374-75 (1928) (Remarks of Mich. Rep. Louis C. Cramton).

522. In the summer of 1927, Taft wrote Van Devanter:

Stone was inclined to urge the Treasury Dept to make some purchases of the lots in the land we seek without condemnation from the Woman's party. Senator Dale \& a constituent came to see him about it. I discouraged him about this. The Woman's Party would never consent to a reasonable price. They want to include as an element the historical associations of that 
wrote to Van Devanter through gritted teeth, "conspires to delay." ${ }^{23}$ The NWP even prompted Arkansas Senator Thaddeus Caraway to introduce a Joint Resolution in the Senate to the effect that the great historical importance of the Old Brick Capitol precluded its ever being torn down. ${ }^{524}$ The Resolution passed the Senate but died in the House. In the end, lawyers handling the condemnation concluded that "[ $t]$ he Woman's Party agitated so much ... that the jury was influenced to the extent of a few thousand dollars." 525

Apart from the condemnation of the land, there was also the question of the design of the building itself. Taft had been Chair of the

ramshackle house of theirs. The Treasury would never consent, and it ought not to do so until by condemnation some idea of the proper ratio between the tax assessment and the market value is established. I hope we are not going to have trouble about our plans and architect but this is very tender ground. I think we could take the matter over to ourselves if we wished to make a fight but the softer way is the better way and I think we can count on Mellon's reasonableness.

Letter from WHT to WVD (June 29, 1927) (Van Devanter papers).

523. Letter from WHT to WVD (July 10, 1928) (Van Devanter papers).

524. See S.J. Res. 156, 70th Cong. (1928); 69 CoNG. REC. 9057-58 (1928); Letter from WHT to Harold Phelps Stokes, Editorial Bd. Member, N.Y. TimES (May 31, 1928) (Taft papers); Letter from Henry H. Glassie to WHT (July 6, 1928) (Taft papers); see also Protests Removal of Old Capitol, EQUAL RTS., June 23, 1928, at 157 ("Our country is not so rich in historic landmarks that we can afford to sacrifice even to an object as worthy as a site for the Supreme Court, a structure so identified with our heroic past."); The Old Capitol, EQUAL RTS., June 30, 1928, at 163; The Old Brick Capitol, EQUAL RTS., Aug. 25, 1928, at 231. Taft noted with cold political calculation that "the claims of the Woman's Party will turn the stomach of a good many who are willing to vote resolutions when it does not cost anything. More than that, the Woman's party will cease to be important after the election." Letter from WHT to WVD (July 10, 1928) (Van Devanter papers); see also Letter from WHT to Cass Gilbert (July 31, 1928) (Taft papers) ("I don't know how much opposition we shall find generated by the Woman's Party, but I rather think that after the election, whatever the result, the opposition will cease to be effective.").

525. Letter from WHT to Charles P. Taft II (Nov. 25, 1928) (Taft papers). Taft wrote his son after the jury verdicts in the condemnation proceedings that the NWP was "content with the award, [because] they need the money, and I hope we can get the thing through. I am to see the women tomorrow morning, but 'There is many a slip twixt cup and the lip,' especially in anything that depends on Congress, so you must pray for me." Letter from WHT to Robert A. Taft (Dec. 2, 1928) (Taft papers). The NWP received \$299,200 for its property. The Old Brick Capitol Goes to Supreme Court, EQUAL RTS., Dec. 29, 1928, at 371. It promptly purchased a new headquarters at 2nd and B Streets (NW) for \$100,000. Woman's Party Buys New Home at Capital, N.Y. TIMES, Mar. 28, 1929, at 24. 
Lincoln Memorial Commission, ${ }^{526}$ which was generally acknowledged to have produced a masterpiece designed by the architect Henry Bacon. We know that at some time Bacon had sketched preliminary drawings for a possible Supreme Court building, ${ }^{527}$ but Bacon passed away in 1924. Taft was also intimately familiar with Cass Gilbert, who at the time was a leading American practitioner of neoclassical architecture. ${ }^{528}$ Taft had appointed Gilbert to the Commission of Fine Arts in 1910 and had stayed in close touch with him ever since. ${ }^{529}$

Taft likely contacted Gilbert about a potential commission as early as fall 1926, when the site for the building was being selected, for in the surviving documentary record we know that Gilbert wrote Van Devanter in November of that year:

Since our conversations in Washington of several weeks ago regarding the Supreme Court, I have given very thoughtful study to the subject and I am so deeply interested in it that I have made some sketches in which I have expressed certain ideas that I would like to place before you. I am writing to the Chief Justice today telling him about it .... The designs work out very well indeed and I think I can show you something that would make a

526. Taft presented the Lincoln Memorial to the Nation on May 30, 1922. See Harding Dedicates Lincoln Memorial: Blue and Gray Join, N.Y. TIMES, May 31, 1922 , at 1.

527. See Letter from WHT to Reed Smoot, Senator, U.S. Senate (July 3, 1925); see also Kennedy, supra note 502 (publishing the Bacon drawings presented to Taft); Hathaway, supra note 502 ("Plans for the structure were drawn by Henry Bacon before his death in February 1924."). In 1926, Time Magazine also reported the Justices as beaming "benignly at the design for the New Supreme Court building by the late Henry Bacon." Supreme Court: Grey Wigs, Time MAG., Oct. 11, 1926, at 8. In 1922, Taft had written a correspondent about a potential architect for a new Supreme Court building that "[o]f course no one would suit me better than $\mathrm{Mr}$. Bacon." Letter from WHT to Jules Guerin (Dec. 2, 1922) (Taft papers).

528. Upon Gilbert's death in 1934, it was said that "[ $\mathrm{t}]$ he list of his most important buildings only would be long enough to prove him the most remarkable architect of his generation in America." Cass Gilbert Dead: Eminent Architect, N.Y. Times, May 18, 1934, at 23. Gilbert's reputation has suffered somewhat in the intervening years. See generally Geoffrey Blodgett, Cass Gilbert, Architect: Conservative at Bay, 72 J. AM. HIST. 615 (1985) (summarizing Gilbert's career).

529. See Letter from WHT to Cass Gilbert (Nov. 27, 1924) (Taft papers) ("I look back upon my association with you with the utmost pleasure, and have had the utmost satisfaction in noting the great work you have done in your profession, the monuments you have built to yourself and the honor you have brought to American architecture."). There is correspondence between Taft and Gilbert in 1925 that does not contain any reference to a potential Supreme Court building. See Letter from Cass Gilbert to WHT (May 18, 1925) (Taft papers); Letter from WHT to Cass Gilbert (May 20, 1925) (Taft papers). 
very distinguished building suitable for the Supreme Court. I am enthusiastic about it myself and I hope that you will like it. ${ }^{530}$

On December 12, 1926, Gilbert sent Taft "the prints of the drawings we spoke of last night.... The plans show only the Main Floor on which is located the Supreme Court Room and Justice's Rooms and the Second Floor on which is located the Library, Court Reporter, and Lawyers Rooms." ${ }^{311}$ Evidently, planning with Gilbert had proceeded very far indeed. ${ }^{532}$

Taft had apparently wasted no time pursuing a two-track approach: pushing the condemnation proceedings, on the one hand, while simultaneously initiating the selection of an architect who could begin the actual planning of the building, on the other. Taft was prepared to write Gilbert in spring 1927 that he hoped that the condemnation proceedings would have concluded by the end of the year, and that

we shall be ready to apply for a suitable appropriation to begin the work. That will require legislation which will enable the Secretary of the Treasury to designate an architect. Without committing myself or my colleagues finally, I think I may say that the exhibition of your plans is favorable to the selection of yourself as the architect, but of course it will have to await the form of the legislation and the consideration of those who have the ultimate authority in the matter..$^{533}$

530. Letter from Cass Gilbert to WVD (Nov. 18, 1926) (Van Devanter papers). Internal evidence suggests that "Bacon's plan" for the building was Gilbert's "starting point." Alan Greenberg and Stephen Kieran, The United States Supreme Court Building, Washington D.C., 128 ANTIQUES 760, 763 (1985).

531. Letter from Cass Gilbert to WHT (Dec. 12, 1926) (Gilbert papers at the Supreme Court of the United States).

532. See id. ("The Ground Story would be all above the ground level and provide ample well lighted rooms about 12' high. There would of course be private entrances and service entrances at the ground story level. And in this story there will be large spaces available for the Clerk, the Marshall, for files and other usage. A slight revision of the space in the Main Story provides rooms for the use of the Attorney General and the Solicitor General when they come to the Supreme Court.").

533. Letter from WHT to Cass Gilbert (Mar. 9, 1927) (Gilbert papers at the Supreme Court of the United States). Taft, ever wily and sophisticated, continued: "I have thought, however, that it might be well if in the course of a month, I could have a Sunday luncheon here in Washington, with the Secretary of the Treasury and his advisory architect, who comes from Chicago, but is now in California, the three Justices who are more directly interested, Justice Van Devanter, Justice Stone and myself, and Senator Moses, and possibly Senator Smoot, so that we can talk over the matter with a view to formulating definite action." Id.

A word should be said about the attitude of Stone. After the completion of the building, Stone was said to be highly disparaging of it, calling it "wholly inappropriate for a quiet group of old boys such as the Supreme Court.” ELDER WITT, GUIDE TO THE 
The difficulty with Taft's approach was that Gilbert could not be reimbursed for preliminary planning until he had been selected by a government commission with authority to choose an architect and supervise his work. Until Gilbert was officially hired, he would have to work on speculation. Taft encouraged Gilbert to take this risk in the hope that the plans which Gilbert produced would convince those in

U.S. SuPREME COURT 781 (2d ed., 1996). "I wonder if we look like the nine beetles in the Temple of Karnak," Cardozo remembers him joking. Arthur John Keeffe, The Marble Palace at 50, 68 A.B.A. J. 1224, 1229 (1982). "Whenever I look at that building," Stone reportedly said, "I feel that the justices should ride to work on elephants." Drew Pearson \& Robert S. Allen, Nine Old Men 9 (1937). In May 1935, Stone wrote his sons that the building was "almost bombastically pretentious." Clare Cushman, Courtwatchers: Eyewitness Accounts in Supreme Court HISTORY 110 (2011). A few months later, Stone wrote Charles Burlingham: "It makes me sad to think [about] Cass Gilbert's Palace of Justice, [and] sadder when I see it, especially its interior." Letter from HFS to Charles C. Burlingham (Oct. 4, 1935) (Stone papers); see also Letter from Charles C. Burlingham, to HFS (Oct. 3, 1935) (Stone papers).

Yet throughout the 1920s, Stone was intimately involved in Gilbert's planning, as Taft's letter suggests. So, for example, Stone wrote Gilbert to say that "the Chief Justice had shown to me the sketches which you had prepared for a Supreme Court Building. I took them home with me and went over them with Mrs. Stone. We found them of absorbing interest and an inspiring suggestion of what could be accomplished in the way of a new building. I would like to have the opportunity sometime to go over them with you to make some suggestions which occur to me which might be of interest to you. I would like very much to see you chosen to prepare the plans. If there is anything I can do to accomplish that end, I hope you will let me know." Letter from HFS to Cass Gilbert (Mar. 24, 1927) (Stone papers); see also Letter from Cass Gilbert to HFS (Mar. 30, 1927) (Stone papers). Stone wrote New York lawyer William Nelson Cromwell: "Confidentially, I very much hope that Cass Gilbert will be the architect of the new Supreme Court Building." Letter from HFS to William Nelson Cromwell (Oct. 22, 1928) (Stone papers). After receiving a photograph of Gilbert's more developed ideas, see Letter from Cass Gilbert to HFS (Jan. 15, 1929) (Stone papers), Stone replied, "We are on the way to have a most beautiful building. Certainly the photograph you sent is a delight to the eye. I think the classical form which you have given it is the only adequate treatment." Letter from HFS to Cass Gilbert (Jan. 17, 1929) (Stone papers); see also Letter from HFS to Cass Gilbert (Jan. 9, 1929) (Stone papers). After receiving a rendering of the final model of the building, Stone exclaimed, "It seems to me that you have designed a building which is, at the same time, unique and dignified, and appropriate to its setting." Letter from HFS to Cass Gilbert (Oct. 7, 1929) (Stone papers); see also Letter from Cass Gilbert to HFS (Oct. $4,1929)$ (Stone papers). After the completion of the building, "when a guest at one of the Brandeis Sunday teas remarked that Stone was complaining about the building and about the acoustics and lighting in the courtroom, Brandeis, recalled his law clerk Paul Freund, replied hotly, 'Well, he voted for it!'” DAVID M. O'BrIEN, STORM Center: The Supreme Court in American Politics 156 (3d ed. 1993). 
authority to hire him. ${ }^{534}$ Gilbert, who was artistically and politically very conservative, was disposed to take this risk because he very much wanted to design the building, which he appreciated would be "the greatest opportunity that has come to an architect since the 1850 s to do a monumental building in Washington." 535 If he succeeded, it would answer the many advocates "of the so-called modernist movement" to which he was aesthetically and professionally opposed..$^{536}$

The challenge before Taft, then, was simultaneously to craft legislation establishing a building commission that would enable the Court to control the choice and supervision of the architect, ${ }^{537}$ while at the same time to extract as much work from Gilbert as he could to justify Gilbert's eventual selection. The latter meant bolstering Gilbert's confidence in the inevitability of his ultimate selection.

While away in Canada on summer vacation, Taft had Van Devanter meet with Secretary of the Treasury Andrew W. Mellon. Although Mellon stressed the need to "proceed without bias respecting particular plans and particular architects," Van Devanter "with deference and recognition of the need for unbiased action ... pressed for an early and tentative consideration of such suggestions as Mr. Gilbert could make, and indicated that he had given the subject much consideration and was interested in it independently of who shall be ultimately chosen as the architect." 538

Van Devanter persuaded Mellon to allow Gilbert to confer with Edward H. Bennett, a Chicago architect and Mellon's special advisor in matters relating to the many public building projects then underway in Washington. "When Gilbert sees Bennett it will be the same as seeing me," Mellon said, "and it will be better because Bennett understands the matter well and I do not. I must necessarily be advised by and rely largely on Mr. Bennett." 539 "Without prejudice to the

534. See WHT to Cass Gilbert (Jan. 23, 1928) (Gilbert papers at the Supreme Court of the United States) ("If you are willing to go on with the work, at your own risk, I shall be glad.").

535. Letter from Charles Moore, Chairman, Comm'n of Fine Arts, to Cass Gilbert (June 12, 1929) (Gilbert papers at the Library of Congress).

536. Letter from Cass Gilbert to Maurice Webb (Jan. 10, 1928), in Blodgett, supra note 528, at 628. Gilbert would later write, "The Supreme Court Building . . . is built of white marble and it is as pure in style as I can make it. I hope it will cause some reaction against the silly modernistic movement that has had such a hold here for the last few years." Letter from Cass Gilbert to Sir Reginald Blomfield (Apr. 5, 1933) (Gilbert papers at the Library of Congress).

537. See Letter from WHT to HFS (June 28, 1927) (Taft papers).

538. Letter from WVD to WHT (June 25, 1927) (Van Devanter papers).

539. Id. 
ultimate adoption of plans and the future designation of an architect," Van Devanter advised Gilbert to seek an opportunity in Washington to meet with Bennett and "to lay before him at an early date the suggestions which you have in mind and the tentative drawing which you have made." ${ }^{540}$

It proved difficult to bring Gilbert and Bennett together, however, and Gilbert awkwardly supposed that Bennett wished to meet with him, rather than the reverse. ${ }^{51}$ But eventually the two men met, and Gilbert reported that "Mr. Bennett expressed himself as in sympathy with my appointment and said that if Secretary Mellon should ask him about it he would so advise him. He seemed, however, to feel that he would await the Secretary's request before volunteering his advice on that matter." ${ }^{4} 2$

Bennett's one concern was that the northern front of the court building, as Gilbert had sketched it, was not parallel to the northern boundary of the lot slated for condemnation, which (then as now) was

540. Letter from WVD to Cass Gilbert (June 25, 1927) (Van Devanter Papers). With the exquisite care and tact for which he was so well known, Van Devanter added, "My interest in the subject is only that of getting an entirely suitable building for the Court and as the tentative drawings which you have submitted have elicited my admiration I suggest that you take the course indicated by the Secretary of the Treasury." Id.

541. See Letter from WVD to WHT (June 28, 1927) (Van Devanter Papers); Letter from WHT to HFS (June 28, 1927) (Stone papers); Letter from WHT to WVD (July 1, 1927) (Van Devanter Papers) ("As you say, everything seems to obstruct our proposal to push things, but that is no reason why we should not press."); Letter from WHT to WVD (July 2, 1927) (Taft papers); Letter from WVD to WHT (July 5, 1927), (Taft papers) ("If Gilbert can handle himself well with Bennett the way will be open to get our building substantially under our own control. Congress will wish to do what is right about it. ... If Secretary Mellon remains at his present post, there probably will be no trouble; his good sense may be depended on."); Letter from WVD to WHT (July 7, 1927) (Taft papers) ("If Gilbert does his part well there is little doubt that the building matter will move along nicely."); Letter from WVD to WHT (July 19, 1927) (Van Devanter Papers) ("The marked part of Gilbert's letter to me suggests that he does not understand the matter as I do. According to my information Bennett was not desiring to see Gilbert, but we were assuming that Gilbert was wishing to see Bennett and we were endeavoring to bring them together.").

542. Letter from Cass Gilbert to WHT (Aug. 3, 1927) (Gilbert papers at the Supreme Court of the United States). See WHT to WVD (Aug. 4, 1927) (Van Devanter Papers) (quoting from Gilbert's telegram: "I had a long conference with Mr. Bennett at my office this morning. He is in hearty sympathy and will act in cooperation. He likes the design and is favorable to my appointment"). In November, Taft reported to his daughter that "Secretary Mellon is very anxious to help us and he is in a position to do so, and I am counting on him." Letter from WHT to Mrs. Frederick J. Manning (Nov. 13, 1927) (Taft papers). 
bounded by the diagonal Maryland Avenue. ${ }^{543}$ Bennett's critique set off a flurry of efforts to move the Court to a different location. ${ }^{544}$ But

543. See Letter from Cass Gilbert to Edward H. Bennett, Chairman, Bd. of Architects (Sept. 15, 1927) (Gilbert papers at the Supreme Court of the United States). Gilbert initially rejected Bennett's suggestion: "I agree with you that it would be well to have this façade parallel with the street but if I must choose between that and an unsymmetrical building, I feel sure that you will agree with me that in a building of such serious and monumental character symmetry should be preserved even if one of the lesser facades does not align with the street. ... [S]ince our conversation I have thought many times of your suggestion of another location. I think however that the problem will have to be solved in the location now selected. The situation then that exists is this, that we have the Library of Congress, which is out of scale with everything around it. It was wrongly placed in the first instance and is out of harmony with the Capitol and with the Senate and House Office Buildings. That being so, it is not clear to me how the Supreme Court Building can be made part of a framework of which the congressional Library is an element; and since the choice must be made between harmonizing with the Library of Congress and harmonizing with the National Capitol, I have no hesitation in accepting the latter alternative, and I believe you will agree with me. The problem would be easier if we could close Maryland Avenue at this point, but I understand that would probably not be recommended by the authorities." Id. Taft immediately approved of Gilbert's response to Bennett: "The suggestion that we should change the location because of the difficulty of securing a proper axis to me is not very formidable. If we allow such reasons to prevail, we shall never get the building located or built either. What has constantly to be done in Washington is to reconcile mistakes made in locating buildings already erected. The lot here chosen by the Building Commission is the one which has always been suggested for the Court." Letter from WHT to Cass Gilbert (Sept. 30, 1927) (Gilbert papers at the Supreme Court of the United States).

544. On November 5, Gilbert sent Taft a sketch that located the Court in a symmetrical position on East Capitol Street. See Sketch by Cass Gilbert (Nov. 5, 1927) (Gilbert papers at the Supreme Court of the United States) ("My new suggestion for location of Supreme Court. Letter of plat sent to E.H. Bennett today. Referred to in letter to Ch. Justice Taft today."); Sketch by Cass Gilbert, Scheme for Locating Sup Court on Axis of East Capitol Street (Nov. 9, 1927) (Gilbert papers at the Supreme Court of the United States). After a luncheon with Charles Moore, Van Devanter, and Gilbert on November 13, Taft was apparently convinced that "we need more land than that which we are now attempting to take. There is a triangle on the other side of Maryland Avenue which we need, and upon which is a costly building of the Methodist Church. I don't know whether we can induce Congress to give it to us, but the architects seem to think that it is necessary." Letter from WHT to Charles P. Taft II (Nov. 13, 1927) (Taft papers); see also Letter from WHT to Anson Phelps Stokes, Resident Canon, Nat'l Cathedral (Nov. 16, 1927) (Taft papers) ("I went up to the place with Justice Van Devanter and Senator Smoot yesterday, and I am more strongly convinced than ever that we ought to take that sliver or triangle on which the Methodist Building stands, and close up Maryland Avenue and make a complete square.").

In January, Gilbert sent Taft sketches locating the Court on a lot that included the triangle north of Maryland Avenue. See Letter from Cass Gilbert to WHT (Jan. 17, 1928) (Gilbert papers at the Supreme Court of the United States) ("I still hope the 
in the end these came to nothing, and Taft wrote Smoot that "[w]e shall have to content ourselves with the block which is now condemned, and I am hoping that in spite of the irregular character of the block as it now is, it can be made a very satisfactory place for the

Congressional Committee will grant all you ask for the Supreme Court, for it will be needed. The building ought not to be put on an irregular shaped plot... . I had not intended again mentioning my suggestion about the site on East Capitol Street because neither Mr. Mellon nor Justice Van Devanter favored it. I still think it would be the best site and the land is less expensive .... It ought to be looked into. However, I do not expect to mention it again. I am afraid to do so."). Gilbert did in fact mention the East Capitol Street again, due to "the long delay in the condemnation and the opposition of the ladies who own a part of the Maryland Avenue site." Letter from Cass Gilbert to WHT (Nov. 13, 1928) (Taft papers).

In the meantime, Frederic A. Delano, Chair of the National Capital Park and Planning Commission of Washington, weighed in with the suggestion that the Court be located in the Tidal Basin. See Letter from WHT to Cass Gilbert (Jan. 13, 1928) (Gilbert papers at the Supreme Court of the United States). But Taft countered that it would be "admirable" if Gilbert would assume the "risk" and if he could "start your people to making the investigation that is necessary on the lot as it is now planned, with Maryland Avenue remaining open." Id. Delano then suggested a site just north of the Capitol that Gilbert thought had "considerable merit." Letter from Frederic A. Delano to Cass Gilbert (Jan. 30, 1929) (Taft papers); see also Letter from Cass Gilbert to WHT (Feb. 1, 1928) (Gilbert papers at the Supreme Court of the United States); Letter from Cass Gilbert to WHT (Feb. 3, 1928) (Taft papers). David Lynn, the Architect of the Capitol, opposed this idea on the ground that it interfered with existing plans for expansion of gardens to the north of the Capitol. See Letter from Frederic A. Delano to WHT (Feb. 6, 1928) (Taft papers). Taft nevertheless asked Delano "to prosecute the matter of which you have written me in your letter of February $6^{\text {th }}$." Letter from WHT to Frederic A. Delano (Feb. 7, 1928) (Taft papers).

It turned out that Charles Moore also had objections to the proposed site north of the Capitol, as did Senator Smoot. See Letter from Cass Gilbert to WHT (Feb. 7, 1928) (Taft papers); Letter from Reed Smoot, Senator, U.S. Senate, to WHT (Feb. 14, 1928) (Taft papers). Lynn proved "pretty obdurate." Letter from Frederic A. Delano to WHT (Feb. 9, 1928) (Taft papers). Lynn counter-proposed a site bounded by New Jersey Avenue, First Street, and B and C Streets, which Delano considered "altogether a very magnificent location." Id. Taft rejected the proposal because it would make the building "so subordinate as to seem a mere side hill concern." Letter from WHT to Frederic A. Delano (Feb. 10, 1928) (Taft papers); see also Letter from WHT to Cass Gilbert (Feb. 10, 1928) (Taft papers). In the end, Delano backed off his objections to the original site as did Gilbert. See Letter from Frederic A. Delano to Cass Gilbert (Feb. 13, 1928) (Taft papers); Letter from Cass Gilbert to WHT (Feb. 14, 1928) (Taft papers) ("It looks as though under all the circumstances surrounding the matter that the original site between East Capitol Street and Maryland Avenue will be adhered to."); see also Letter from WHT to Cass Gilbert (Feb. 16, 1928) (Taft papers) ("I think you ought now to devote yourself to shaping the front of the block as it is, so as to eliminate its narrower front as far as you can from the picture."); Letter from Cass Gilbert to James C. Beck (Nov. 28, 1933) (Gilbert papers at the Library of Congress) (discussing the siting of the building). This letter is also Gilbert's most elaborate explanation of the design choices that went into his design. 
Court." ${ }_{545}$ With characteristic persistence, Taft added, "Could you tell me what would be the prospect of our getting an authority to go ahead with the building as soon as the condemnation is completed? It would mean much to us if we could put the thing right through." 546

Having secured Mellon's agreement to Gilbert's selection and settled the question of the site, Taft turned his attention in spring 1928 to crafting legislation that would create a commission effectively allowing Taft to choose the building's architect and giving "a free hand to the Architect, subject only to the control of the Commission." ${ }_{547}$ This would also prove a delicate, protracted, and difficult task. Without consulting the Court, David Lynn, the Architect of the Capitol, who possessed "a good many friends" in Congress, ${ }^{548}$ caused a bill to be introduced that interposed his office between the Court and the building. ${ }^{549}$

Lynn's bill created a Supreme Court building Commission consisting of the Chief Justice, the chair and the ranking minority member of the Senate Committee on Public Buildings and Grounds, the chair and the ranking minority member of the House Committee on Public Buildings and Grounds, and the Architect of the Capitol. Lynn's bill made "the Architect of the Capitol virtually Architect of [the] building," because it appointed the Architect of the Capitol the executive officer of the commission and invested the executive officer with "power to appoint consulting architects and others." ${ }_{550}$ The bill also gave the Architect of the Capitol supervision of the building after it was built. The proposed bill essentially disrupted all of Taft's welllaid plans to ensure Gilbert's selection as the building's architect.

Taft was livid. He had Van Devanter redraft the bill to make Lynn merely the Commission's executive officer, to authorize the Commission to hire "an architect of established national reputation" who would then supervise the construction of the building, and to provide that the Architect of the Capitol would be the custodian of the completed Supreme Court building only under "the supervision and

545. Letter from WHT to Reed Smoot, Senator, U.S. Senate (Feb. 15, 1928) (Taft papers).

546. Id. Smoot answered that "after the condemnation proceedings of the proposed land ... there will have to be an estimate of the cost of the building and a direct appropriation made for the same." Letter from Reed Smoot to WHT (Feb. 20, 1928) (Taft papers).

547. Letter from WHT to Cass Gilbert (Apr. 24, 1928) (Taft papers).

548. Letter from WHT to Nicholas Longworth, Congressman, U.S. House of Representatives (May 1, 1928) (Taft papers).

549. See S. 4151, 70th Cong. (1928).

550. Telephone interview with Cass Gilbert (Apr. 25, 1928) (Taft papers). 
direction" of the Court. ${ }^{551}$ In a letter of white hot fury, Taft explained the amendments to Senators Edwards, Warren, Gould, and Swanson, who served on the Senate Public Buildings and Grounds Committee:

I wish to secure your assistance and influence in helping our Court to have part of a voice in the selection of an architect and the construction of the new Supreme Court Building. The architect of the Capitol, without any consultation with any member of our Court, it would seem, had secured the service of a clerk in the Appropriations Committee of the House to draft a bill ... and it was introduced by Senator Keyes as Chairman of the Public Buildings Committee of the Senate, and by Mr. Elliott as Chairman of the Public Buildings Committee in the House. Mr. Elliott told me he knew nothing about the bill, but he was requested to introduce it and he put it in, and I don't know exactly how Senator Keyes came to introduce it except that he told me it was drafted over in the Appropriations Committee of the House. I think our Court ought to have been consulted before the bill was introduced. We could have made some suggestions. It was introduced, however, and then the House Committee members, Mr. Elliott of Indiana and Mr. Lanham of Texas, having heard that some criticism had been manifested, came to see Justice Van Devanter and myself, and suggested that we might attempt to draft a bill. We then [met with] Senator Keyes and

551. Taft's amended version of the bill may be found in H.R. 13665, 70th Cong. (1928); see also Letter from WHT to Richard N. Elliott, Congressman, U.S. House of Representatives (Apr. 26, 1928) (Taft papers); Letter from WHT to Henry W. Keyes, Senator, U.S. Senate (Apr. 26, 1928) (Taft papers); Letter from WHT to Fritz G. Lanham, Congressman, U.S. House of Representatives (Apr. 26, 1928) (Taft papers). Taft's amendments also provided that "an Associate Justice to be designated by the Court" be added to the Commission, giving the Court a total of two members, the Senate two, and the House two. Representatives Elliott and Lanham, the ranking members of the House Public Buildings and Grounds Committee, were sympathetic to Taft's revised bill, which they had seen on April 26. "So far as I am concerned" there "is nothing" in your proposed changes "that I could not agree to." Letter from Richard N. Elliott to WHT (Apr. 27, 1929) (Taft papers); Letter from Fritz G. Lanham to WHT (Apr. 27, 1928) (Taft papers); Letter from WHT to Henry W. Keyes (May 1, 1928) (Taft papers). Without Taft's knowledge, however, Senator Henry Keyes, Chair of the Senate Public Buildings and Grounds Committee, had already introduced S. 4151 on April 20, and Taft felt blindsided. See Letter from WHT to James A. Reed, Senator, U.S. Senate (May 3, 1928) (Taft papers). "The course taken with respect to [S. 4151] indicates," Taft said, that the Architect of the Capitol "did not care to have the Court consulted in the matter, although it is a matter in which it seems to me it would have been proper that the Court should be consulted." Letter from WHT to Nicholas Longworth, Congressman, U.S. House of Representatives (May 1, 1928) (Taft papers). For his part, David Lynn was highly offended by Taft's proposed revisions. See Letter from WHT to Richard N. Elliott (Apr. 30, 1928) (Taft papers); Letter from WHT to Fritz G. Lanham (Apr. 30, 1928) (Taft papers) ("We have no desire to humiliate the architect of the Capitol, but we have a feeling that when the Commission selects an architect of established national reputation, we ought to make him subject to the Commission alone and not interpose another architect between him and the Commission."). 
discussed the matter with him and criticized the bill, and he, too, suggested that we draft an amendment. Now we have done so on the framework of the old bill. The difficulty about the bill which was introduced was that it attempted to put all the power possible in the hands of the architect of the Capitol. Under the Commission he was to select the consulting architects and was really to do the work not only as one of the commissioners but also as executive officer of the Commission. And then after the building was built, he was to be the custodian, without any control or supervision given to the Court. I think that was unfair. ... So in our framing of the bill we dropped the architect of the Capitol from the Commission and left him an executive officer. Then we did what we think is of the utmost importancewe provided the Commission should itself select an architect of national reputation, who should make the plans and construct the building, subject of course to the Commission. That is the way we built the Lincoln Memorial, and the way I think we ought to build this Building. Of course our Court is more interested than anyone else in the character of the building to be built, and it did seem to me that in making the architect of the Supreme Court building [sic] the custodian, there ought to be at least a provision that we could have supervision over the custodian of our own building and exercise some control in his management of the building as custodian. I therefore amended the bill as suggested by Senator Keyes, and Mr. Elliott and Mr. Lanham, and I wish to ask you as a member of the committee to see whether you can not approve the form of the bill as we have drafted it. We had a Conference of our Court yesterday, and I went over the amended bill, and the members of our Court are very earnestly anxious to have the bill go through as I have drafted it. I . . . appeal to you, my dear Senator, to help us out in this matter and see to it that we do have an architect of national reputation so that we can invoke his genius in the work, subject of course to the Commission, but give him more or less the responsibility and a free hand to see that he does the best work. ... I understand that the architect of the Capitol declines to be what he calls a handy man for some other architect though of national reputation. Well, we don't insist on having him. If he prefers not to serve as executive officer, we could take Colonel Grant, who is the engineer officer in charge of Public Buildings and Grounds. . . . It is a very serious matter with us, and we feel very deeply about the mistake that may be made unless we follow the course that has vindicated itself in the selection of the architect. ${ }^{552}$

552. Letter from WHT to Edward I. Edwards, Senator, U.S. Senate (May 1, 1928) (Taft papers); Letter from WHT to Francis Warren, Senator, U.S. Senate (May 1, 1928) (Taft papers); Letter from WHT to Arthur R. Gould, Senator, U.S. Senate (May 1, 1928) (Taft papers); Letter from WHT to Claude A. Swanson, Senator, U.S. Senate (May 1, 1928) (Taft papers); see also Letter from Edward I. Edwards to WHT (May 3, 1928) (Taft papers) ("For the life of me I can not appreciate the attitude of those responsible for the drafting of the Keyes measure in neglecting to consult your Court prior to the introduction of the Keyes and Elliott measures in the Congress."); Letter from Arthur R. Gould to WHT (May 3, 1928) (Taft papers); Letter from Claude A. Swanson to WHT (May 5, 1928) (Taft papers). Despite the richness of the Taft collection, it is plain from internal evidence that there is much correspondence that is missing, so that we can only reconstruct a portion of Taft's lobbying campaign. See, 
Taft sent similar angry letters to Senators Ashton and Fess on the Public Buildings and Grounds Committee and to his old friend Nicholas Longworth, Speaker of the House. ${ }^{553} \mathrm{He}$ also sent pleas for help to Senators Reed, Shipstead, and Gerry. ${ }^{554}$ Taft was hoping to obtain agreement

upon a satisfactory bill. It has given me a great deal of concern, and it has taken me a good deal of time in making clear what we would like in the Court. ... We are very anxious to have Cass Gilbert as the architect. He is an outstanding figure now among the architects of the country and the World, and we want the best man we can get. ${ }^{555}$

On May 10, 1928, Taft did succeed in having his version of the legislation introduced into the House, ${ }^{556}$ and a week later he and Van Devanter testified in support of the legislation, over the sullen

e.g., Letter from Robert L. Bacon, Congressman, U.S. House of Representatives, to WHT (May 4, 1928) (Taft papers).

553. See Letter from WHT to Henry F. Ashurst, Senator, U.S. Senate (May 1, 1928) (Taft papers); Letter from WHT Simeon Fess, Senator, U.S. Senate (May 1, 1928) (Taft papers); see also Letter from WHT to George H. Moses, Senator, U.S. Senate (Apr. 26, 1928) (Taft papers); Letter from WHT to Nicholas Longworth, Congressman, U.S. House of Representatives (May 1, 1928) (Taft papers). Taft sent this same letter to Representative Hatton W. Sumners, who was the ranking minority member of the House Judiciary Committee. See Letter from WHT to Hatton W. Sumners, Congressman, U.S. House of Representatives (May 1, 1928) (Taft papers). Longworth agreed "that the Court should have the choice of the architect of the building, and I think the matter can be easily arranged. I have talked to Elliott and he thinks as I do, and I don't see any real reason why, under such circumstances, Mr. Lynn could not effectively cooperate." Letter from Nicholas Longworth to WHT (May 4, 1928) (Taft papers).

554. See Letter from WHT to Peter G. Gerry, Senator, U.S. Senate (May 2, 1928) (Taft papers); Letter from WHT to Henrick Shipstead, Senator, U.S. Senate (May 2, 1928) (Taft papers); Letter from WHT to James A. Reed, Senator, U.S. Senate (May 3, 1928) (Taft papers). Reed and Shipstead were members of the Senate Public Buildings and Grounds Committee, which had jurisdiction of the bill. Rhode Island Senator Gerry was not a member of the Committee, but he had offered to donate "his father's very large Law Library of 30,000 volumes, with some rare books" to the Court, on the condition that they be "placed together" in the new "Supreme Court Building as a gift from him." Letter from WHT to Cass Gilbert (Mar. 9, 1927) (Gilbert papers at the Supreme Court of the United States). After consulting with Gilbert, Taft had accepted the offer. See Letter from WHT to Peter G. Gerry, Senator, U.S. Senate (Feb. 7, 1928) (Taft papers). Taft's appeal to Gerry prompted the latter to affirm: "I shall be very glad to do what I can to be helpful in the matter." Letter from Peter G. Gerry to WHT (May 3, 1928) (Taft papers).

555. Letter from WHT to Robert A. Taft (May 6, 1928) (Taft papers).

556. See H.R. 13665, 70th Cong. (1928). Taft complained to Gilbert: "I am so busy trying to get through the work that stands between me and adjournment that I can not spend as much time at the Capitol as I would like to." Letter from WHT to Cass Gilbert (May 12, 1928) (Taft papers). 
protestations of Lynn. ${ }^{557}$ But Congress was not prepared simply to snub its own Architect, and action on the bill was long delayed while a compromise was hammered out. Legislation establishing a "United States Supreme Court Building Commission" was not enacted until December 21, 1928. ${ }^{558}$ The legislation provided that the building was

557. See Hearings on H.R. 13665, S. 4035, H.R. 5952, S.J. Res. 50, and H.R. 12290, supra note 452. On Lynn's obduracy, see id. at 10-12. Van Devanter was particularly eloquent on the need for the Court to supervise the custodianship of its completed building:

Who is the Architect of the Capitol—not as a person-but who is he?

$\mathrm{He}$ is under, of course, the domination of the Congress of the United States, the legislative branch. We are the judicial branch. We have heretofore found that when, through no fault of our own, we come in contact with the legislative branch, if they want a room, they get it. That is the plain fact; it is true....

[T] he custody of that building ... ought not be with the representative of the legislative branch of the Government; it ought not to be with anybody who could say, to Senator So-and-so, here is a room in the Supreme Court; you go over and occupy it; or he can say to Representative So-and-so, here is a room over there you go over and occupy it.

There ought to be in connection with that building a declaration that that shall be exclusively for the Supreme Court, so that the court can control that .... Let us have the divorce, just as it ought to be.

Id. at $17-18$.

558. Act of Dec. 21, 1928, Pub. L. No. 70-644, 45 Stat. 1066. The bill was opposed by Alabama Senator J. Thomas Heflin. The power of Taft's genial persuasion can be seen in Reed Smoot's defense of the legislation, which was widely quoted in the press:

Nearly every justice of the Supreme Court ... [has] to do much of their work at home. There is no place but a cubby-hole or two here at the Capitol Building for the Supreme Court of the United States. . . I can not think of any necessity that is more pressing upon the Government than providing a proper place for the Supreme Court of the United States. . . .

Of course, I did not agree with some of the ideas as to closing Maryland Avenue and buying the next block to the north and spreading the Supreme Court from the Library to B Street; I thought that was perfectly silly; I thought that there was no necessity for it at all, but in view of the size of the lot which has been purchased, and the character of the building designed, I wish to say to the Senator it will be an honor to America when it shall have been erected....

Every American is proud that there is [a Library of Congress]. When they go there they will see, across the street, the Supreme Court, a most beautiful building, and they will go in there; and every American's heart will be filled with pride to know that the United States Supreme Court - the greatest body in the world for the administration of law-is housed in a building that will do honor to any country in the world, I do not care what country it is.

70 Cong. REC. 931-32 (1928). These remarks stand in sharp contrast to Smoot's initial comments in 1926 on the need for a Supreme Court building, supra note 493. 
"to be so situated, and the exterior thereof to be of such type of architecture and material, as to harmonize with the present buildings of the Capitol group." ${ }_{59}$ It altogether sidestepped any questions involving the actual construction of the building or its custodianship after it was completed. It kept the Architect of the Capitol as a member of the Commission and as its executive officer, although it provided that a second Justice of the Court would also be a member of the Commission. ${ }^{560}$ It authorized $\$ 10,000$ for the Commission "to procure, by contract or otherwise, preliminary plans and estimates of costs for the construction, and the furnishing and equipping, of a suitable building ... for the accommodation and exclusive use of the Supreme Court of the United States." ${ }_{561}$ The Commission was to report back to Congress by March 1, 1929. ${ }^{562}$

Taft was satisfied with the compromise because "I think we have arranged for legislation that will enable us to secure" Cass Gilbert's appointment as architect. ${ }^{563}$ The Commission itself would procure the

See Lucille A. Roussin, The Temple of American Justice: The United States Supreme Court Building, 20 CHAP. L. REV. 51, 51 (2017); A Supreme Court Building, N.Y. TIMES, Dec. 24, 1928, at 12

559. $§ 2,45$ Stat. at 1067 .

560. This was in accordance with Taft's proposed bill. See H.R. 13665, 70th Cong. 1067 (1928).

561. Id.

562. Taft was so focused on the legislation's enactment that Vice President Dawes reports that Taft called him "[l]ess than fifteen minutes" after its passage to ask "whether I had signed the bill and expressing his anxiety to have it signed by President Coolidge before he left Washington for the holidays. This I arranged within an hour, to his considerable satisfaction." CHARles G. DAwES, NOTES AS VicE PRESIDENT 1928-1929, at 194 (1935).

563. Letter from WHT to Mrs. Frederick J. Manning (Nov. 17, 1928) (Taft papers). See Letter from WHT to Mrs. Frederick J. Manning (Dec. 9, 1928) (Taft papers); Letter from WHT to Mrs. Frederick J. Manning (Dec. 16, 1928) (Taft papers). On Taft's nimble creation of the compromise legislation, see Letter from WHT to WVD (Dec. 7, 1928) (Taft papers); Letter from WHT to Henry W. Keyes, Senator, U.S. Senate (Dec. 7, 1928) (Taft papers); Letter from WHT to Henry F. Ashurst, Senator, U.S. Senate (Dec. 7, 1928) (Taft papers); Letter from WHT to Richard N. Elliott, Congressman, U.S. House of Representatives (Dec. 7, 1928) (Taft papers); Letter from WHT to Fritz G. Lanham, Congressman, U.S. House of Representatives (Dec. 7, 1928) (Taft papers). ("The condemnation proceedings pending in the Supreme Court of the District to secure for the Government and the Supreme Court Building two lots on the Capitol Square, have proceeded to such a point that they will be completed ... all within six weeks as soon as the first deficiency appropriation bill shall pass appropriating the $\$ 268,000$ needed to cover the entire award. Such progress would seem to require that legislation be now enacted to provide for the Commission which was fully discussed in the last session of Congress. It seems to me, therefore, as if it would be wise to have a conference among those immediately interested and 
required plans, and Taft had spent the summer convincing Commission members that Cass Gilbert was the man to draft them. On June 4, 1928, he had written Senator Henry Keyes, Chair of the Senate Public Buildings and Grounds Committee, to the effect that Charles Moore, longtime friend of Taft and Chair of the Commission of Fine Arts,

telephoned me on Saturday last, ... that he had had a conversation with you and with Mr. Lynn, in which you both said that you were quite willing to allow us, Mr. Justice Van Devanter and myself, to go on the hypothesis that when the bill for the Commission passes, you will use your influence with ours to secure the appointment of Mr. Cass Gilbert as the architect to be given the duty and powers substantially like those in the bill already suggested by us, and that it would be wise to have Mr. Gilbert help in the speedy progress of the building to prepare during the summer the needed sketches and plans, with an estimate of the probable cost, to be submitted to Congress for its consideration after the passage of the bill constituting the Commission.

We had a meeting last night. Mr. Cass Gilbert was here on another matter with his son, Mr. Lynn was good enough to come, Justice Van Devanter was here, and Mr. Frederic Delano, and we talked over the whole matter. Mr. Gilbert discussed it at great length, as indeed did Mr. Lynn. Mr. Gilbert said it was something he had never done before, but with the assurances of the Judges and the probable members of the committee he would go ahead with the work for the purpose of speeding it, in the matter of preparation of preliminary plans and an estimate, assuming the risk in the matter, but depending on our earnest assurance that we would do everything we could to work the matter out as we now are planning it. May I ask you

taking part in the matter within the next day or two."). Keyes, Elliott, Lanham, Van Devanter, and Lynn were future Commissioners of the United States Supreme Court Building Commission. Taft apparently believed that Ashurst would be on the Commission, see Letter from WHT to Charles P. Taft II (Dec. 23, 1928) (Taft papers), but Ashurst was in fact only the second ranking minority member on the Senate Public Buildings and Grounds Committee. Missouri Senator James A. Reed was actually the ranking minority member and so became the seventh Commissioner. See Minutes of the Organization Meeting of the Commission Named in Public No. 644 (Jan. 4, 1929). Although Reed was slated to step down from the Senate on March 4, 1929, special legislation was enacted at Reed's request that permitted him to remain a commissioner. See Pub. RES. 70-106, 45 Stat. 1698 (1929). On the floor of the Senate, Ashurst generously announced that "I am possessed of no talents that can ever bring me into even the most courteous competition when measured and weighed with those talents of the Senator from Missouri [Mr. Reed], and I hereby gladly and cheerfully waive in his favor such privilege of priority as I might have on this commission." 70 Cong. ReC. 3743 (1929). See Letter from Richard N. Elliott, Congressman, U.S. House of Representatives, to WHT (Feb. 15, 1929) (Taft papers); Letter from WHT to Richard N. Elliott (Feb. 16, 1929) (Taft papers); Letter from WHT to Charles Moore, Chairman, Comm'n of Fine Arts (Mar. 7, 1929) (Taft papers) (noting that Reed "is very much interested in the work"). 
to conform [sic] Mr. Moore's statement with reference to your attitude in the matter? ?64 $^{64}$

On June 26, Keyes had telegrammed back: "I am very glad to confirm Mr. Moore's statement to you relative to Mr. Gilbert in matter of Supreme Court Building." "565 Taft was delighted, for it was "exactly what I wish, in order that I may show to Mr. Gilbert the basis upon which he may rely in making the sketch of the plans which in order to expedite matters he ought to have ready, with his estimates." 566 "With Keyes in our favor," Taft wrote Van Devanter in July, "and with [the chair and the ranking minority member of the House Committee on Public Buildings and Grounds] Elliott and Lanham, I think we can do something as soon as Congress meets." ${ }^{567}$

By fall 1928, Gilbert was able to report "excellent progress," 568 and Taft was "delighted to know that things are working themselves out in your mind to meet the difficulties that the situation presents in the matter of the lot." ${ }^{569}$ In November, Taft hosted a luncheon of Van Devanter, Stone, and Charles Moore to review Gilbert's plans and sketches. ${ }^{570} \mathrm{He}$ had wanted to include Lynn, ${ }^{571}$ but Gilbert demurred: "I am a little doubtful about going beyond that until the Act of Congress authorizing the work has been passed." ${ }_{572}$ By the end of the year, Taft was convinced that Cass Gilbert "has really gotten up a very beautiful building." ${ }^{773}$ Gilbert "has been working very hard, because he regards it as his monumental work." ${ }^{574}$

After hosting a dinner for future members of the Supreme Court Building Commission, ${ }^{575}$ Taft reported that "[ $[$ ]hey have all practically

564. Letter from WHT to Henry W. Keyes, Senator, U.S. Senate (June 4, 1928) (Taft papers).

565. Letter from WHT to Henry W. Keyes, Senator, U.S. Senate (July 1, 1928) (Taft papers).

566. Id. Taft immediately forwarded Keyes's telegram to Gilbert, asking if Gilbert had "been able to do any work" in the last month. Letter from WHT to Cass Gilbert (July 1, 1928) (Taft papers).

567. Letter from WHT to WVD (July 10, 1928) (Van Devanter papers).

568. Letter from Cass Gilbert to WHT (Sept. 7, 1928) (Taft papers).

569. Letter from WHT to Cass Gilbert (Sept. 9, 1928) (Taft papers).

570. See Letter from WHT to Mrs. Frederick J. Manning (Nov. 17, 1928) (Taft papers).

571. See Letter from WHT to Cass Gilbert (Nov. 9, 1928) (Taft papers).

572. Letter from Cass Gilbert to WHT (Nov. 13, 1928) (Taft papers).

573. Letter from WHT to Charles P. Taft II (Dec. 9, 1928) (Taft papers).

574. Letter from WHT to Robert A. Taft (Dec. 23, 1928) (Taft papers).

575. See supra note 563 and accompanying text. 
agreed that we shall select Cass Gilbert as the Architect." 576 Taft's strategy had worked to perfection. Once the legislation creating the Commission passed on December 21, the remaining steps seemed to Taft clear and determinate:

\begin{abstract}
We shall need an appropriation of upwards of $\$ 10,000$ to pay for the preliminary sketches and estimates. We shall have to meet and organize, appoint an Architect, who will be Cass Gilbert, and then it will be his business to make the estimates and have them ready on or before the first of March. He will be ready with them, if we are, on or before the first of February. Then will come the struggle as to the amount that Congress will be willing to authorize for the Building. We ought to have $\$ 9,000,000$. It would not be too much to give us $\$ 10,000,000$, because we shall be building a building for a century certainly. ${ }^{577}$
\end{abstract}

Ever the optimist, Taft believed that because Gilbert "has been doing a good deal without authority," the Commission could "get in the sketches and plans and estimates in a month or more." 578

Once again, however, the way forward lay strewn with brambles. Matters started off auspiciously enough. The minutes of the Commission's first meeting on January 4 recount that Taft, who had been elected Chair, "related his consultation with the architect Cass Gilbert upon matters wherein it was felt that the Supreme Court needed advice and suggestions. The chairman asked David Lynn the architect of the Capitol in relation to the standing and ability of Mr. Cass Gilbert, and in answer to this inquiry Mr. Lynn replied that he considered Mr. Gilbert one of the outstanding architects of the city of New York." ${ }^{779}$ During the ensuing discussion "it was stated by Senator Reed, that the proposed building should be of such a character that it would reflect the majesty of the United States and the dignity of the Supreme Court of the United States, and that to erect such a building should be the first consideration and question of cost a secondary matter." 580

576. Letter from WHT to Robert A. Taft (Dec. 16, 1928) (Taft papers); see also Letter from WHT to Charles P. Taft II (Dec. 16, 1928) (Taft papers) (noting that the architect "will be Cass Gilbert").

577. Letter from WHT to Charles P. Taft II (Dec. 23, 1928) (Taft papers); see also Letter from WHT to Robert A Taft (Dec. 23, 1928) (Taft papers); Letter from WHT to Cass Gilbert (Dec. 21, 1928) (Taft papers) ("I hope that the land will be ours and paid for before the middle of January.... There remains nothing now but to secure the appropriation for $\$ 10,000$, and that we hope for . . . in January.").

578. Letter from WHT to Mrs. Frederick J. Manning (Dec. 16, 1928) (Taft papers).

579. See Minutes of the Organization Meeting of the Commission Named in Public No. 644 (Jan. 4, 1929).

580. Id. 
At the Commission's second meeting on January 9, over dinner at Taft's home, Cass Gilbert presented his sketches. Senator Reed suggested that it was important to illustrate the plans "by models" as well as by drawings. ${ }^{581}$ But the Commission held back from requiring its executive officer to negotiate a contract with Gilbert for the preparation of "plans and specifications," because the deficiency appropriation bill, containing the $\$ 10,000$ fee for the payment of the contracts, had been held up by a dispute in Congress about prohibition funding. ${ }^{582}$ It was uncertain whether the Commission could enter a binding contract without the appropriated funds to do so. "I hope you will go right on with your work without regard to the appropriation," Taft wrote Gilbert, "for when it passes we want to be in a situation to act at once. ... Don't be impatient, for unless something unfortunate [happens], matters will go on as we desire." 583 The models requested by Senator Reed added to the Commission's embarrassment, because the models were estimated to cost approximately $\$ 10,000$ that could not be advanced out of pocket. ${ }^{584}$

The Commission was required by law to produce its report by March 1, but the deadlock stalling the deficiency bill seemed to stretch on interminably. Gilbert fulfilled his side of the bargain, submitting an estimate of $\$ 8,992,000$ for the building, exclusive of "fixed or

581. See Meeting Minutes from Supreme Court Bldg. Comm'n (Jan. 9, 1929) (Supreme Court Archives).

582. Letter from WHT to Cass Gilbert (Jan. 15, 1929) (Taft Papers). The controversy, according to Taft, involved "the obstinacy of some drys in the Senate." Letter from WHT to Charles P. Taft II (Feb. 17, 1929) (Taft Papers). This was the same deficiency bill that was required to provide the added funds to complete the condemnation proceedings for the land for the Supreme Court building. See supra note 514 .

583. Letter from WHT to Cass Gilbert (Jan. 15, 1929) (Taft papers).

584. Lynn had communicated with his model maker, who was "willing to go ahead with his work" even in the absence of immediate compensation. Id. But Gilbert insisted that the models be constructed in New York. See Letter from Cass Gilbert to WHT (Jan. 16, 1929) (Taft Papers). "I am anxious to have the work done here under my personal instruction so that I can visit it frequently while under way. If they are made in Washington I would have to prepare very careful and practically final drawings before the models could be begun and here I can do it more rapidly by personal instruction and by more or less fragmentary sketches explanatory of the cross sections." Letter from Cass Gilbert to David Lynn, Architect, U.S. Capitol Bldg. (Jan. 18, 1929) (Taft Papers); see also Sharon Irish, Cass Gilbert in Practice, 1882-1934, in Inventing the Skyline: The Architecture of Cass Gilbert 18-19 (Margaret Heilbrun ed., 2000) (discussing the importance of models to Gilbert's architectural practice); Letter from Cass Gilbert to WHT (Jan. 18, 1929) (Taft Papers) (discussing the costs). 
movable furniture and furnishings, mural decoration and sculpture." To account for contingencies, Gilbert recommended an appropriation of $\$ 10,000,000 . .^{586}$ But the Commission remained "in a most exasperating situation." ${ }^{587}$ Both the House and Senate agreed to raise the budget of the Commission to $\$ 25,000$ to pay for the models, ${ }^{588}$ but the deficiency bill itself remained mired in seemingly endless controversy. In February Taft wrote his son about the embarrassment of the delay, because "the time between now" and March 1 "hardly gives us an opportunity to make the report in time." 589

Something had to be done, and so Taft, working with Richard N. Elliott, sought legislation extending the Commission's deadline. ${ }^{590}$ It was a race against time, but on February 23, only a week before the report was due, Congress provided that the report could be postponed until "the first day of the first regular session of the Seventy-first Congress," which would be in December. ${ }^{591}$ The relief was palpable. Even though its funding had not yet materialized, the Commission met

585. Letter from Cass Gilbert to WHT (Jan. 29, 1929) (Taft Papers).

586. Letter from Cass Gilbert to WHT (Jan. 29, 1929) (Taft Papers).

587. Letter from WHT to Cass Gilbert (Jan. 31, 1929) (Taft Papers).

588. Id.; see also Letter from WHT to William R. Wood, Chairman, Republican Nat'l Cong. Comm. (Feb. 4, 1929) (Taft Papers).

589. Letter from WHT to Charles P. Taft II (Feb. 3, 1929) (Taft Papers). To compound Taft's worries, Gilbert began to show signs of impatience at the "very disappointing" delay. Letter from Cass Gilbert to WHT (Feb. 5, 1929) (Taft Papers). At the beginning of February, Gilbert wrote to Taft: "It will take a long time after the plans are adopted to make the working drawings and specifications, so that if we are to get under way actually - under construction - this season, we ought to have definite authority to go ahead now." Id. Gilbert was also growing anxious about how detailed his estimates ought to be to survive constitutional scrutiny, for he'd "like to be prepared in advance for such function as I may be expected to perform." Id. He reminded Taft that Taft and Van Devanter had advised Gilbert not to include "such items as furniture, mural decoration, sculpture, etc." in his estimates, "as they would probably run the estimate up too high." Id. "An additional appropriation" would be necessary to cover these expenses. Id. Taft sought to comfort Gilbert saying, "The delay, due to the fight over the deficiency bill, is really most exasperating, but there is nothing to do but to swear and swear with moderation, conscious that ultimately we are going to get it through." Letter from WHT to Cass Gilbert (Feb. 8, 1929) (Taft Papers).

590. See Letter from WHT to Richard N. Elliott, Congressman, U.S. House of Representatives (Feb. 8, 1929) (Taft Papers); Letter from Richard N. Elliott to WHT (Feb. 9, 1929) (Taft Papers); Letter from WHT to Richard N. Elliott (Feb. 13, 1929) (Taft Papers); Letter from Richard N. Elliott to WHT (Feb. 15, 1929) (Taft Papers).

591. Pub. Res. No. 70-90, 45 Stat. 1261 (1929). 
on March 3, 1929,592 and authorized Lynn "to prepare a form of contract with Cass Gilbert ... for the preparation of preliminary plans and estimates of cost and models for the Supreme Court Building." ${ }_{593}$ And the following day the long-awaited Deficiency Bill finally passed, funding the Commission to the tune of $\$ 25,000 .{ }^{594}$ In triumph, Taft wrote his daughter, "I am glad to say that we are in a situation now to begin the preliminaries of the work of the new Supreme Court Building. We have selected Cass Gilbert to make the plans." 595

After so much risk and anticipation, it was a triumphant moment for Gilbert. He confided to his diary: "Thus opens a new chapter in my career and at 70 years of age I am now to undertake to carry through the most important and notable work of my life... . God grant me strength, courage and intelligence to do it well." ${ }^{596} \mathrm{He}$ wrote his wife that he had "asked Chief Justice Taft to give me the pen which he and I used in signing - to which request he smilingly assented. It is a mottled brown penholder with a steel pen. We will keep it as a souvenir." ${ }^{597}$ Gilbert was determined to make the edifice

592. Taft scheduled the meeting on March 3 so that the legislative members of the Commission would not "get away" from Washington with the adjournment of Congress on March 4. Letter from WHT to Cass Gilbert (Mar. 7, 1929) (Taft Papers).

593. Meeting Minutes from Supreme Court Bldg. Comm'n (Mar. 3, 1929) (Supreme Court Archives). Gilbert's contract was formally signed at the Commission's meeting of April 10, 1929. See Meeting Minutes from Supreme Court Bldg. Comm'n (Apr. 10, 1929) (Supreme Court Archives). Gilbert had essentially worked for two and half years, and had produced detailed plans, all in the hope of eventually be selected as the architect. That Taft could have maintained this arrangement is remarkable.

Oddly, on the motion of Taft and Van Devanter, the Commission on March 3 also "resolved that Senator Reed and the Architect of the Capitol, constitute a committee to take into consideration the enlargement of the proposed Supreme Court lot, to include all the property bounded by Maryland Avenue, First Street, B and Second, which includes the property now occupied by the Methodist Building." Meeting Minutes from Supreme Court Bldg. Comm'n (Mar. 3, 1929) (Supreme Court Archives). At its meeting of April 10, letters were read from the Commission of Fine Arts and the National Capital Park and Planning Commission to the effect that they "were not favorable to the acquisition of additional ground and the closing of Maryland Avenue." Meeting Minutes from Supreme Court Bldg. Comm'n (Apr. 10, 1929) (Supreme Court Archives).

594. Pub. Law No. 70-1034, 45 Stat. 1609 (March 4, 1929).

595. Letter from WHT to Mrs. Frederick J. Manning (Mar. 10, 1929) (Taft Papers).

596. Blodgett, supra note 528, at 632 (quoting Gilbert's diary entry).

597. Letter from Cass Gilbert to Mrs. Cass Gilbert (Apr. 10, 1929) (Gilbert Papers at the Library of Congress). 
the most perfect and complete monumental building possible, and at the same time meet all of the practical requirements . . . [I]t must, so far as possible, have all the beauty, charm and dignity of the Lincoln Memorial, and all the practical qualities of a first-rate office building - a combination rather difficult to achieve, but nevertheless possible..$^{598}$

Of course such perfection did not come cheap. Taft worried that "[ $t]$ he building is going to be very costly, and I don't know how much effort we shall have to make with the two Houses of Congress to get what we really ought to have." 599 "It is a monumental building, to be made of marble, and is very much more expensive than the ordinary department building which is more in its cost like that of the ordinary office building." ${ }^{600}$ The remainder of 1929, however, would prove anticlimactic, a virtual victory lap. ${ }^{601}$

On June 1, the Commission approved its report to Congress. ${ }^{602}$ It requested authorization for $\$ 9,740,000$, "exclusive of furniture and book stacks." ${ }_{003}$ The Commission met a week later at Taft's hospital bed-Taft had just returned from a week in Cincinnati and the exertion of the railroad trip had caused "an attack of cystitis, due to much alkali in my urine" 604 - to finalize the "the bill to be introduced authorizing

598. Letter from Cass Gilbert to WHT (Jan. 16, 1929) (Taft Papers).

599. Letter from WHT to Charles P. Taft II (Apr. 14, 1929) (Taft Papers).

600. Letter from WHT to Robert A. Taft (Apr. 14, 1929) (Taft Papers).

601. It must be "a building of such dignity and such extent as to represent the Judicial Branch of the Government," Taft told the ALI in May, "[a]nd I am glad to say that our experience so far with the Committees is that they are filled with enthusiasm - if I may say so - in regard to the construction of such a building." Chief Justice Taft's Address, supra note 253, at 332.

602. See H.R. Doc. No. 36, 71st Cong. (1929) (on file at the United States Supreme Court Building). The report was approved at the Commission's meeting of June 1. See Meeting Minutes from Supreme Court Bldg. Comm'n (June 1, 1929) (Supreme Court Archives). At that meeting, there was a moment of discomfort when "[t]he question was asked whether the plans and models when executed would result in a building which would be suitable to all of the members of the Supreme Court for a Court house, to which the Chief Justice replied that he had heard no unfavorable comment upon the plans and that some of the Justices had been very enthusiastic regarding the Court building being constructed from the designs submitted." Id.

603. Taft wrote his daughter that "I don't know whether we can get the appropriation needed, but we are going to do the best we can. We haven't as yet had reason to complain of the generous attitude of Congress in respect to the matter. I am hoping that as Congress is to appropriate a very large amount for the various buildings here, they will not be ungenerous to us in respect to the Supreme Court Building. I am very well satisfied with it as planned." Letter from WHT to Mrs. Frederick J. Manning (June 2, 1929) (Taft papers).

604. Letter from WHT to Robert A. Taft (June 7, 1929) (Taft papers). Taft wrote Mrs. Herbert Hoover to thank her and the President for the flowers they had sent: "Life is constantly teaching me that the time when I expect much is the time 
the construction" of the building. ${ }^{605}$ A few days later, bills were introduced in both the House (H.R. 3864) ${ }^{606}$ and the Senate (S. 1482), ${ }^{607}$ each seeking the authorization of the $\$ 9,740,000$ requested by the Commission. 608

And then nothing much happened, because Taft was "not anxious to press the matter so as to make it too conspicuous." ${ }^{609}$ The massive building projects begun earlier in the decade were coming to a climax,${ }^{610}$ and Taft was "hoping the matter may come up in regular form and be passed on as part of the building program." 611 Taft accurately perceived that "the temper of the House and of Congress seems to be toward the expenditure of money for good buildings." ${ }^{612}$

when I should be prepared for disappointment. I had planned out a pleasant little trip to my old home where I had not been for three or four years, to see my brother and his wife and Bob and Charlie and their families. The truth is I went out with too much enthusiasm, and I am afraid that I yielded to temptation and socialized too much, so that when I came back I had sense enough to come right to the hospital." Letter from WHT to Mrs. Herbert Hoover (June 9, 1929) (Taft papers). To Van Devanter, Taft was more blunt: "My visit to Cincinnati was an error in that I forgot the limitation on my activities. I have to keep constantly before me that I can do so much and no more." Letter from WHT to WVD (June 19, 1929) (Van Devanter papers).

605. Meeting Minutes from Supreme Court Bldg. Comm'n (June 8, 1929) (Supreme Court Archives). The bedside meeting was reported in the press. See Taft Is Improved; to Leave Hospital, WASH. Post, June 9, 1929, at 6.

606. See H.R. 3864, 71st Cong. (1929).

607. See S. 1482, 71st Cong. (1929).

608. To give this figure a sense of scale, consider that in January Congress had authorized $\$ 8,400,000$ for the construction of a new annex to the House office building. Act of Jan. 10, 1929, Pub. L. No. 70-649, 45 Stat. 1071. In March, it had authorized $\$ 4,912,414$ for the enlargement of the Capitol grounds. Act of Mar. 4, 1929, Pub. L. No. 70-1036, 45 Stat. 1694.

609. Letter from WHT to Charles P. Taft II (Oct. 13, 1929) (Taft papers).

610. A good capsule summary of the building program may be found in Richard N. Elliott, Elliott Describes Building Program, WASH. Post, June 8, 1930, at 9. Suffice it to say that on March 31,1930 , Congress authorized a $\$ 115,000,000$ increase in spending for public buildings in Washington D.C., bringing the total of such expenditures to $\$ 227,890,000$. Pub. L. No. $71-85$, 46 Stat. 136. The House approved that statute on the very same day that it would ultimately approve the authorization for the Supreme Court. See House Passes \$230,000,000 Buildings Bill, The Herald Trib., Dec. 17, 1929, at 15. Support for public building on this scale dwarfed the $\$ 10,000,000$ price of the Supreme Court building. Id.

611. Letter from WHT to Robert A. Taft (Oct. 13, 1929) (Taft papers).

612. Letter from WHT to Robert A. Taft (Dec. 1, 1929) (Taft papers); see also supra notes 608, 611, and accompanying text. The stock market crash had occurred in October, and in response to resulting labor dislocations President Hoover was at this precise time vigorously sending "telegrams to all state governors, urging them on to an 'energetic, yet prudent, pursuit of public works' as a means of absorbing unemployment.” Mind and Momentum, TIME, Dec. 2, 1929, at 11. 
When Congress opened in December, Taft pounced. "I am going out on a campaign tomorrow morning," he told his brother. ${ }^{613}$ "I must do something about the Supreme Court Building. Congress has been so slow in the meetings of the committee-indeed in organizing the committees, that we are quite behind and this week I am going to devote myself to lobbying. . . . I expect to devote a good deal of time to trying to get the Committee on Buildings and Grounds to appropriate the money necessary to build our Supreme Court Building and to approve the plans." ${ }^{\prime \prime 14}$

Taft had a strong ally in Richard N. Elliott, the powerful Chair of the House Public Buildings and Grounds Committee and member of the Supreme Court Building Commission. Elliott promptly held hearings that paired consideration of H.R. 3864 with a bill authorizing an increase of $\$ 115,000,000$ for public buildings in the District of Columbia. ${ }^{615}$ His object was plainly to push through the former:

Ladies and gentlemen, we have already committed ourselves to the construction of the new Supreme Court Building. . . . We procured the services of Mr. Cass Gilbert, one of the best architects in the United States, and we had the plans and specifications and estimates prepared, the commission has reported those back to Congress with a unanimous report. ...

This building will necessarily be an expensive building because it has to be rather large to take care of the needs of this court. It has to be an ornamental building for two reasons. One is that the highest court in the land is entitled to it. The other is because it is located among a group of ornamental buildings....

The estimate of the cost of this building is $\$ 9,740,000 \ldots$.

I do not know whether any member of the committee wants any further hearings on this matter or not. If they do not, I would be glad if somebody would move to report this bill for passage. ${ }^{616}$

The bill was unanimously reported to the House. With a speed that no doubt sprang from Congress's respect for Taft and the urgency of his quest, as well perhaps from an awareness of the growing fragility of

613. Letter from WHT to Horace D. Taft (Dec. 8, 1929) (Taft papers).

614. Letter from WHT to Mrs. Charles P. Taft (Dec. 8, 1929) (Taft papers); see also WHT to Charles P. Taft II (Dec. 8, 1929) (Taft papers).

615. See Letter from WHT to Robert A. Taft (Oct. 13, 1929) (Taft papers); see also Hearings before the House Committee on Public Buildings and Grounds on H.R. 3864 and H.R. 6120, 71st CoNG. (Dec. 13, 1929).

616. See Hearings before the House Committee, supra note 615, at 12-13. Elliott added, "I wish to say before you vote, that these plans are entirely satisfactory to the Supreme Court, to all of the members of the court." Id. at 13. 
his health, the bill was enacted into law without opposition on December $20 .{ }^{617}$

It was a triumph for Taft, who at every step had played his cards perfectly. "This has been a great week for me," he wrote his son,

\begin{abstract}
in that we got through the Supreme Court Bill, and now have sitting in the treasury, subject to call by an appropriation bill, $\$ 9,600,000$ ready to be spent whenever we need it. Everything is done in respect to the matter, and there is nothing to prevent our building the building except the work. It is a good deal more than I expected . . . . Considering the circumstances, I think it is a great achievement. Everybody helped us. There was not any sour person to prevent, and really I was deeply gratified to find how much interest there was in pressing the matter. . . . What now remains, so far as I am concerned, is to live long enough to get the building dedicated, but I don't know that I can expect that. However, the step we have taken is irretrievable and can not be changed. ${ }^{618}$
\end{abstract}

Two weeks later Taft was hospitalized. He would never again to return to the Court.

Cass Gilbert wrote Taft a condolence note upon Taft's formal resignation in February. "I shall always think of you as the real author of the project and the one to whose vision we shall owe a suitable housing for the Supreme Court of the United States. It will, in fact, be a monument to your honored name." 119 Taft's long-time personal secretary thanked Gilbert for his "kind letter." "I wish I could bring it to the Chief Justice's attention," he wrote, "but I am afraid it is too late to do so. He is in a very weakened condition and he hardly recognizes anyone. ... I know with what pride he selected you as the Architect for the new Supreme Court Building, and I am sorry he can not live to see it erected, for it would be a monument to him." ${ }^{20}$

A month later a plaster model of the new Supreme Court building was placed near Taft's casket as he lay in state at the Capitol. ${ }^{61}$

\title{
CONCLUSION
}

Laying the cornerstone of the monument that Taft had struggled so mightily to create, Chief Justice Hughes was undoubtedly correct

617. See Pub. L. No. 71-26, 46 Stat. 51 (1929).

618. Letter from WHT to Robert A. Taft (Dec. 22, 1929) (Taft papers).

619. Letter from Cass Gilbert to WHT (Feb. 4, 1930) (Taft papers).

620. Letter from Wendell Mischler to Cass Gilbert (Feb. 5, 1930) (Taft papers).

621. See Hundreds File Past Taft Bier in Capitol, N.Y. Times, Mar. 12, 1930, at 15; Nation Turns Today to Capitol Rotunda, WASH. Post, Mar. 11, 1930, at 1. 
to observe in 1932 that "[f]or the enterprise now progressing to completion ... we are indebted to the late Chief Justice William H. Taft more than to anyone else.... [T] his building is the result of his intelligent persistence." 622

In countless ways, the new Supreme Court building embodied Taft's vision of the federal judiciary. ${ }^{623}$ The primary justifications for the building were the "imperative requirements" imposed by "the physical needs of administration," 624 and it was Taft who had so effectively and prominently called forth a vision of federal courts and federal law as requiring continual management and supervision. Just as the charm of the Old Senate Chamber meant little without a properly functioning clerk's office, so a prestigious Article III judiciary meant little if it could not efficiently deliver justice. Taft understood this, and he had pushed hard for the Act of September 14, 1922. He sought to create a Court building with the facilities necessary for the most efficient possible administrative functionality. With Gilbert, he attempted to ensure that "the practical working elements of the building are as simple and modest and as sanitary as a modern office building should be." 625

\section{Hughes, supra note 450, at 728 .}

623. See Judith Resnik \& Dennis E. Curtis, Inventing Democratic Courts: A New and Iconic Supreme Court, 38 J. SuP. CT. Hist. 207, 208 (2013) ("The Court's architecture and imagery looked back to enlist the authority of lawmakers long gone. Yet, the building's interior also marked the Court's new legal authority to control its own docket, the Chief Justice's ascendancy as the chief executive of the federal judicial system, and the special role the media would come to play in shaping understandings of the judiciary.").

624. Corner Stone of New United States Supreme Court Building Laid: Address of Chief Justice Hughes, 18 A.B.A. J. 724, 728 (1932).

625. Letter from Cass Gilbert to James M. Beck (Nov. 28, 1933) (Gilbert papers at the Library of Congress). Interestingly, given the difficulties Taft experienced as a politician, see supra note 97 and accompanying text, Taft was firm that the building provide "for the convenience and comfort of the press. Press association correspondents have space, equipped with chairs, tables and a quietly operating pneumatic tube leading directly to a space reserved for the press on the ground floor, directly in front of the bench, while correspondents for individual newspapers have similar accommodations close by." High Court Holds Opening Session in New Building, Christian SCI. Monitor, Oct. 7, 1935, at 5; see also Cass Gilbert, Jr., The United States Supreme Court Building, 72 ARCHITECTURE 301, 302 (1935) ("For the first time, at the insistence of the late Chief Justice Taft, adequate provision for the press is made in the Court Room and below stairs.").

McReynolds had a very different perspective on the practical functionality of the building. He wrote his brother:

We are in the new building. From an artistic viewpoint it is admired.

From a practical standpoint it is a mess. I never was in favor of it: but really did not suppose that in practice it would be such a failure. To maintain it 
Taft believed that the judiciary ought to manage itself. He was committed to the professional autonomy of the legal system as a separate and equal branch of government. He thus sought to bring judicial appointments out from under the thumb of political patronage. Leading the Court out from under the Capitol dome, where the Court's every necessity was subject to the political whim of Congress, well expressed these convictions. ${ }^{626}$ The legislation creating the Supreme Court building specified that it would be "for the accommodation and exclusive use of the Supreme Court of the United States." ${ }^{27}$ It marks the first moment in its history when the Court could fully control its own space. ${ }^{628}$

By setting the Court apart from Congress, the building also signified the equality of the judicial branch within the constitutional tripartite division of powers. ${ }^{629}$ Sitting atop a terrace carefully elevated so that the baseline of its columns "corresponded with the base line of columns of the Capitol," 630 the Court addressed the legislature in a manner "fitting its dignity as one of the three great branches of government."631 This expressed the Court's new role after the

will cost probably $\$ 200,000$ a year. Seventy five men \& women will be required to keep it clean. It will prove a decided detriment to the Court in my humble judgment. Keep all this to yourself however. No use of advertising my feelings on the subject.

In addition to all else the lighting of the courtroom is so bad that I cannot sit there without bad eye strain. I've been off the bench three days this week. The hope is that corrections can be made during the recess wh[ich] commences next Monday.

Letter from JCM to Robert McReynolds (Oct. 24, 1935) (McReynolds Virginia papers).

626. On the rhetoric of "divorce," see supra note 557.

627. Act of Dec. 20, 1929, Pub. L. No. 71-26, 46 Stat. 51 (1929).

628. See Herbert Little, Taft Made Improvements in Supreme Court, WasH. DAILY News, Feb. 10, 1930, at 11 ("[T]he tremendous separate Supreme Court building which is to cover two blocks facing the Capitol ... will, for the first time in the court's history, set it apart physically as well as legally from the co-ordinate legislative and executive branches of the government."). In the judgment of contemporary commentators, the building "reflected the degree to which the Court had extricated itself from Congress and achieved its ambition to become the hub of federal judicial authority." Resnik \& Curtis, supra note 623, at 231.

629. It was understood that "a monumental Supreme Court building" would "establish the judiciary as the equal, architecturally at least, of the legislative and executive branches of the government." Herbert Little, The Omnipotent Nine, 15 AM. MERCURY 48, 50 (1928).

630. Meeting Minutes from Supreme Court Bldg. Comm'n (May 23, 1929) (Supreme Court Archives).

631. Will P. Kennedy, Supreme Court Home to Be Taft Memorial, Bos. Traveler, Jan. 2, 1929. 
Judiciary Act of February 13, 1925, which "transformed" the Supreme Court "from a forum that primarily corrected errors arising in ordinary private litigation to a constitutional tribunal that resolved public policy issues of national importance." 332 The Supreme Court was now "the head of the Federal judiciary, and, in a constitutional sense, the head of the Judiciary of the Nation." ${ }^{633}$

The restrained classical design of the Court's new building, its pure white marble exterior, also invoked the severe and disinterested virtues necessary for subjecting the polity to the discipline of law. ${ }^{634}$ The Old Senate Chamber had exuded a distinctly different flavor. It was infused with an "easy informality." 635 Justices "often strolled through the public halls, and the procession from the robing room to the courtroom proper was a twice-daily spectacle which tourists always tried to see." ${ }^{636}$ In the Court's new home, by contrast, Gilbert

632. Peter G. Fish, Judiciary Act of 1925, in The OXFord COMPANION TO THE Supreme Court of the United STATES 477 (Kermit L. Hall et al. eds., 1992).

633. Letter from WHT to Reed Smoot, Senator, U.S. Senate (July 3, 1925) (Taft papers); see also Letter from WHT to Charles Curtis (Sept. 4, 1925) (Taft papers). "[T]he American people ... have erected the new structure of the Supreme Court on a site near the Capitol, as if to fix it there forever as a coordinate branch of their Government. They expect it to remain secure in all its duties and functions so long as the Government itself endures." Still the Supreme Court, N.Y. TIMES, Oct. 8, 1935 , at 22 .

634. Gilbert strongly believed in the educational value of architectural form:

The poor man can not fill his home with works of art. The State can, however, satisfy his natural craving for such things in the enjoyment of which all may freely share, by properly embellishing its public buildings .... There the rich and the poor alike may find the history of the state and the ideals of its government set forth in an orderly and appropriate way in noble inscriptions, beautiful mural paintings and sculpture and in the fine proportions and good taste of the whole design.

It is an inspiration toward patriotism and good citizenship, it encourages just pride in the state, and it is an education to on-coming generations to see these things, imponderable elements of life and character, set before the people for their enjoyment and betterment. The educational value alone is worth to the state far more than its cost .... It is a symbol of the civilization, culture and ideals of our country.

Cass Gilbert, The Greatest Element of Monumental Architecture, 136 AM. ARCHITECT 141, 143-44 (1929).

635. Supreme Court Convenes in New Marble Temple, ST. LouIS Post DisPatch, Oct. 7, 1935, § 2, at 1 .

636. Id. In the old courtroom, "as if to emphasize the closeness of the Court to American life, the bench was barely elevated from the chamber floor. The distance between lawyers in the well of the courtroom and the seated justices was close enough to permit an atmosphere of almost conversational intimacy." SEYMOUR I. TOLL, ZONED AMERICAN 234 (1969). 
deliberately screened off from public view the Justices' quarters, their entries and exits. ${ }^{637}$ The Justices became visible to "the public gaze" only when they magically appeared from behind the red curtains to take their seats on the bench, fully robed. ${ }^{638}$ In the new Courthouse the law became spectacle, detached from ordinary human interaction.

Of course the paradox is that Taft, as I have taken pains to illustrate in this Article, was probably more involved in the give-andtake of ordinary political transactions than any Justice before or since. Perhaps for this very reason Taft felt the need sharply to create material distinctions between his role as a simple Justice and his role as a Lord Chancellor-like Chief Justice. Or perhaps Taft sensed the manifest trend of the twentieth century, which has been toward the cloistering of judicial life from apparent political engagement. In any event, the contemporary Supreme Court building has come to symbolize contemporary ideals of judicial office, which stress the formality, detachment, and abstraction of the judicial role. In this setting, the pronouncements of the judge lose their nature as a communal project and become instead disinterested words from above or beyond.

It is fair to say that Taft wanted it both ways. He loved judicial authority, but he also loved the play of politics, the leadership and creation of living institutions. It is because of the latter that Taft was able to create the Supreme Court building; but in the design of that building Taft gave himself entirely over to the former. He created a pure heaven of serene and perfect justice. But any such split is invariably fatal. By the time the Court actually occupied the new building in 1935, it had already thrown down the gauntlet to the New Deal, so that the "white marble temple" 639 could acquire a hard and

637. See Supreme Court Takes Old Chairs in Moving, N.Y. Times, Oct. 3, 1935, at 27 ("The elaborate new Supreme Court Building ... provides new isolation for the justices. Their offices and conference rooms are in a section of the building from which the public is barred by bronze gates."). The isolation of the Justices was baked into the plans from the very beginning. See supra note 533 and accompanying text; see also Maxwell Bloomfield, Architecture of the Supreme Court Building, in The Oxford Companion to the Supreme Court of the United States 52-53 (2005).

638. Supreme Court Convenes in New Marble Temple, supra note 635, at 1.

639. Supreme Court Meets Today Facing Rulings on AAA and Other Laws Vital to the New Deal, N.Y. TIMES, Oct. 7, 1935, at 1. 
cold edge. ${ }^{640}$ It could become to some "a building symbolic of the Court's intransigence," a "sepulchral temple of justice."

The generous funding of the new Supreme Court building was made possible by the much larger project of beautifying Washington D.C. ${ }^{642}$ Like the Supreme Court building itself, this project was driven by the growing administrative needs of an expanding federal government. Congress chose to address these needs through the architectural metaphor of Augustan Rome. ${ }^{643}$ The new federal buildings were the material expression of Pax Americana.

Cass Gilbert had striven for analogous symbolism. He wanted to make the actual Supreme Court courtroom "express the serious beauty and quietly refined splendor of a Courtroom of the classic period of Rome." ${ }^{644}$ Taft's brother Henry wrote Gilbert that the courtroom "will

640. See High Court Meets Amid New Splendor, N.Y. TimES, Oct. 8, 1935, at

2.

[T] he intimacy of the rich little old room in the Capitol where the court sat for seventy-five years was missing in the new, majestic chamber with its huge Sienna marble columns, ornate ceiling, heavy crimson hangings and bas-reliefs. The scene was magnificent but it was strange to the court attachés, hundreds of attorneys and spectators and probably to the nine justices, although they did not reveal it.

This unfamiliar atmosphere was prevalent throughout the great building, where spaces seemed vast as compared to the distance from the clerk's office to the court chamber in the Capitol. Lawyers and attendants were lost going from one quarter to another. In the white marble entrance hall one whimsical justice is said to have remarked:

"I wonder if we look like nine black beetles in the temple of Karnak."

See High Court Uneasy in Its New Home: Nostalgia Grips Veterans as they Strive to Settle in Their Superb Quarters, N.Y. TIMES, Oct. 13, 1935, at 11. Only Sutherland and Roberts moved into their chambers in the new building. Even those who had voted for the building, like Van Devanter, Butler and Stone, continued working at home. It is only when Justice Black moved into his chambers in 1937 that the building began, as it were, to become domesticated into the lives of the Justices. It was not until the Vinson Court in 1946 that all nine Justices began regularly working in the building. See O'BRIEN, supra note 533, at 156.

641. PEARSON \& Allen, supra note 533, at 3-4; see also WitT, supra note 533 , at 781 .

642. See supra notes 484-492 and accompanying text.

643. See Minnigerode, supra note 490, at 18.

644. Letter from Cass Gilbert to Benito Mussolini (Aug. 11, 1932) (Gilbert papers at the Library of Congress). Like many Americans of the time, Gilbert admired Mussolini, and he actively sought the dictator's assistance in acquiring the Italian marble that Gilbert had insisted be used in the courtroom. Gilbert met with Mussolini in June 1933, to discuss the situation:

I said I had thought it would interest him to know of these matters first hand \& that I wanted him to know of them from me, as I had the greatest admiration for him \& for what he had done $\&$ is doing for Italy. I moved to 
be very beautiful, and the selection of the Roman feeling particularly appropriate, as the Romans were the first of the ancients who developed a system of law which has lasted down through the centuries." 645

The authority of Roman law, however, rested on Roman imperial power. As Gilbert well knew, the tropes of Roman architecture instilled thoughts "of the impressive power of Rome." ${ }^{646}$ For this very reason, the sociologist David Riesman recalls that Brandeis "with all the power of indignation, detested the building. He hated everything 'Roman' about Washington and, sharing his decentralist views and some of his asceticism, so did I." ${ }^{647}$ Whereas Gilbert believed that Americans ought to be filled with "national spirit and patriotic pride" at the august strength of the American state, ${ }^{648}$ Brandeis thought just the opposite. He believed that purpose of the state was to empower citizens to control their own destiny.

It is plain that the architectural vocabulary of the Supreme Court courtroom instructs its audience passively to receive the words of the Bench with "respect and honor." ${ }^{4} 9$ The building as a whole thus

withdraw. He put out his hand across the table \& said very simply "Goodbye - Goodbye"! We shook hands \& I turned \& walked rapidly to the door, reaching which I turned sharply around and raised my hand in the Roman Salute - as he did the same. And I shall always think of him as standing in the somewhat dim light of that great room alone, with his hand up above his head in the most impressive of gestures, the Roman Salute, which is so characteristic of the great organization he has created-The Facisti - and which he has led so successfully for nearly eleven years.

Memorandum from Cass Gilbert on "Mussolini" (June 6, 1933) (Gilbert papers at the Library of Congress).

645. Letter from Henry W. Taft to Cass Gilbert (Feb. 15, 1932) (Gilbert papers at the Library of Congress); see also Irish, supra note 584, at xxxvi.

646. CASS Gilbert, REMINISCENCES AND AdDRESSES 67 (1935).

647. Letter from David Riesman to Geoffrey Blodgett (Jan. 31, 1984), in Blodgett, supra note 528, at 634 n.44. Reisman was Brandeis's law clerk. In contrast to his attitude toward Roman imperial power, Brandeis loved the polis of the ancient Greeks. See Vincent Blasi, The First Amendment and the Ideal of Civic Courage: The Brandeis Opinion in Whitney v. California, 29 WM. \& MARY L. REv. 653, 686-89 (1988). Another Brandeis law clerk, Paul Freund, observed that Brandeis "opposed the new Supreme Court building on the ground that it might tend to cause the Justices to lose whatever sense of humility they had theretofore possessed." Paul A. Freund, The Supreme Court: A Tale of Two Terms, 26 Oніо ST. L.J. 225, 229 (1965).

648. GILBERT, supra note 646, at 67.

649. Letter from Elihu Root to Cass Gilbert (Feb. 25, 1932) (Gilbert papers at the Library of Congress). Root, whose visage is carved on the Court's front pediment, was rapturous about the new Court building. He wrote Gilbert that "the photographs of the new Supreme Court building ... fill me with joy. . . . The interior impresses me as especially fine. I am most deeply impressed when I look at that. It is fortunate that 
perfectly expresses and radiantly magnifies Taft's response to the popular critique of judges: courts were never to be degraded by "democratization," ${ }^{650}$ but instead to be rendered more effective and efficient. The Supreme Court courtroom places its audience in the posture of a properly positioned jury, poised deferentially to receive instruction in law from elite, professional judges. Within two years of the opening of the building, however, the positionality of that exchange was to be radically challenged in Roosevelt's court packing plan.

Taft had charged Gilbert to design the building "to last for all time." ${ }_{551}$ That meant, as the Building Commission's plans were presented to Congress in 1929, explicitly providing for only "nine suites for justices." ${ }^{652}$ The number nine was, as it were, fixed in marble. The New York Times passingly observed in 1935 that the building "reflects a confident expectation that nine Supreme Court justices are all we are ever going to have." ${ }^{653}$ The nine suites of the building did indeed survive unscathed the thunderous cross-currents of the New Deal constitutional crisis.

Taft, whose reclining figure as a young man was carved in the northern corner of the front portico of the building, would no doubt have liked that conclusion. Perhaps Taft, having worked himself literally to death to produce the white incarnation of an idealized image of justice beyond time and politics, had the last laugh. But no doubt that laugh expressed the knowing perception that Professor Taft at Yale Law School had once unknowingly communicated to his student Karl Llewellyn - that the heaven of law is always constructed in the "arena" of politics. ${ }^{654}$ To the consternation of purists, the

this is so, for the men who are to sit in this room will have no physical power. They will control no treasury and no soldiers. They wield only a moral power but that power is in its nature superior to all other forces of government, and the respect and honor in which the Court is held are essential to the preservation of liberty and order. Here, above all other places, art should express respect and reverence." Gilbert included in the "Maxims for My Office Organization" the aphorism that "[r]emember that dignity of bearing commands respect — familiarity breeds contempt." Irish, supra note 584, at 1 .

650. Taft, The Attacks on the Court, supra note 106, at 4.

651. Supreme Court Home Will Cost $\$ 9,740,000$, N.Y. Times, June 7, 1930, at 1.

652. H.R. Doc. No. 36, 71st Cong. 12 (1929).

653. R.L. Duffus, An Epochal Day for the Supreme Court, N.Y. TIMES MAG., Oct. 6, 1935, at 6 .

654. Karl Llewellyn was Taft's student at Yale, and he has bequeathed us a piquant portrait of Taft the law professor: 
unlikely union of the two is forever visible in Taft's stupendous but incomparable efforts to redefine the office of Chief Justice of the United States.

He knew nothing of case teaching. Someone would be asked to state the case. Taft would correct the statement as needed-which closed the "discussion." Then - and he sold the class (including me, may the Lord forgive me) the idea that this was only for interest, for anecdote-there would be five to fifteen minutes from Taft, the man of politics; Taft, the student of governmental history; Taft, the student of life and man; Taft, who both from inside and from out had seen political arena, the bench, and all varieties of executive office. . . Taft imparted to us by his manner his own clear feeling that it was no part of "the law" or, really of "the course." Thus - almost the only piece which is still with me- "And I said to Holmes: 'But do you think it was right or fair to leave that fact out of consideration?' And," continued Taft with the mountainous chuckle, "he said, 'I'm sorry; I didn't read that far in the record."

Such phenomena spell a man who felt the bearing of all the "background" and "human" and "situation" factors, and felt also deep value in communicating them, but whose conscious and doctrinal thinking saw them nevertheless as "outside" ....

The matter is clinched by Taft's treatment of doctrine itself. From time to time... he would produce an intellectual scalpel and slice the court's phrased ruling down into an almost nothing. You then got, with another half-ton chuckle: "Mr. Justice Zilch sometimes let enthusiasm run away with him!"

Now I had a good brain and no sense, and this scalpel technique was as exciting to the one as it was uninhibited by the other. I started volunteering applications of it to opinions which Taft had never had professional reason to distinguish. Such admiring misuse of his technique ... seemed to him that of a boor and a blasphemer. He complained to the Dean: he did not want to be subjected to half-grown children in the law "criticizing the Supreme Court of the United States."

Karl N. Llewellyn, The Common Law Tradition: Deciding Appeals 21-22 (1960). 